\title{
$\Psi$ UnB
}

UNIVERSIDADE DE BRASÍLIA - UNB

CENTRO DE EXCELÊNCIA EM TURISMO - CET

PROGRAMA DE MESTRADO PROFISSIONAL

O CCBB COMO ANFITRIÃO: UMA REFLEXÃO SOBRE O TURISMO E A HOSPITALIDADE A PARTIR DO DISCURSO PROFERIDO PELO CENTRO CULTURAL BANCO DO BRASIL BRASÍLIA NO SITE E NO FACEBOOK

Adelaide Cristina Nascimento de Oliveira

Brasília/DF

2016 
O CCBB COMO ANFITRIÃO: UMA REFLEXÃO SOBRE O TURISMO E A HOSPITALIDADE A PARTIR dO DISCURSO PROFERIDO PELO CENTRO CULTURAL BANCO DO BRASIL BRASÍLIA NO SITE E NO FACEBOOK

Dissertação apresentada ao Programa de PósGraduação do Centro de Excelência em Turismo da Universidade de Brasília como pré-requisito para a obtenção do grau de Mestre em Turismo, área de concentração: Cultura e Desenvolvimento Regional; Linha de Pesquisa: Cultura e Sustentabilidade no Turismo.

Orientadora: Prof. ${ }^{a}$ Dr. ${ }^{\text {a }}$ Eloísa Pereira Barroso 
Ficha catalográfica elaborada automaticamente, com os dados fornecidos pelo(a) autor(a)

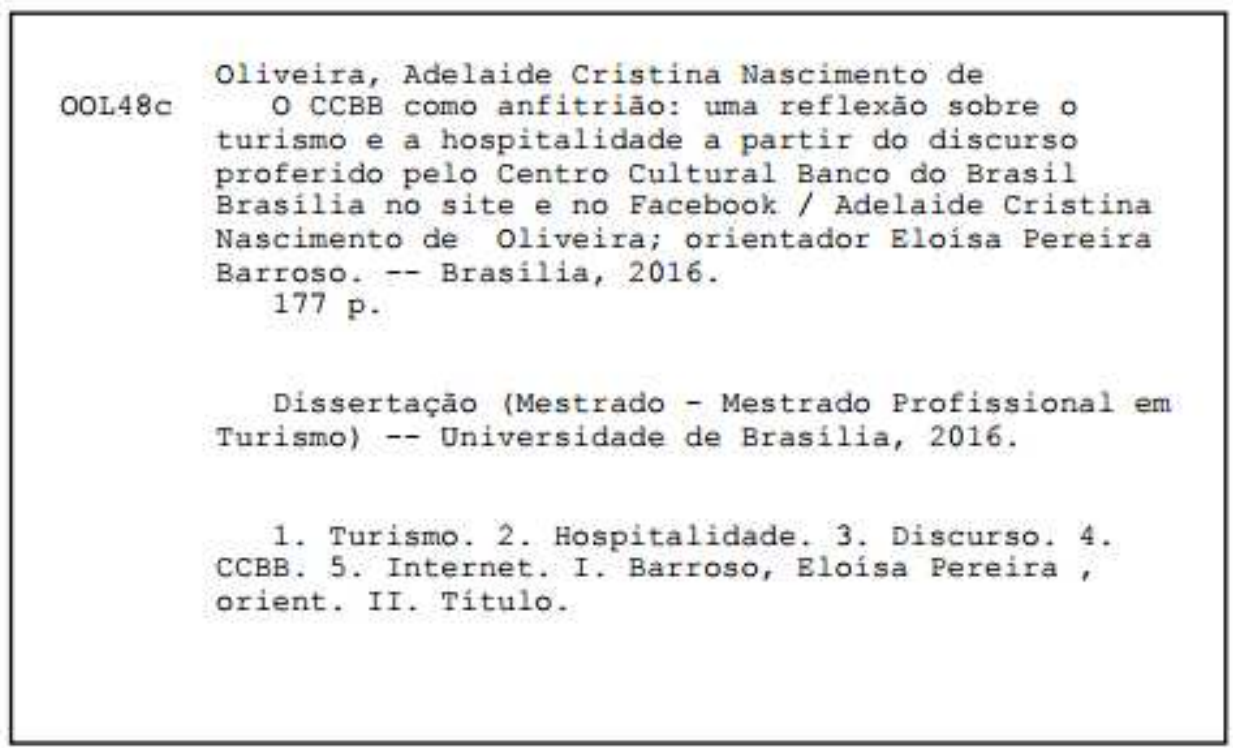




\author{
O CCBB COMO ANFITRIÃO: UMA REFLEXÃO SOBRE O TURISMO E A \\ HOSPITALIDADE A PARTIR DO DISCURSO PROFERIDO PELO \\ CENTROCULTURAL BANCO DO BRASIL BRASÍLIA NO SITE E NO FACEBOOK
}

ADELAIDE CRISTINA NASCIMENTO DE OLIVEIRA

Dissertação apresentada ao Programa de Pós-Graduação do Centro de Excelência em Turismo da Universidade de Brasília como pré-requisito para a obtenção do grau de Mestre em Turismo, área de concentração: Cultura e Desenvolvimento Regional; Linha de Pesquisa: Cultura e Sustentabilidade no Turismo, defendida em 04 de março de 2016. Banca Examinadora constituída pelas professoras:

Prof. $^{\text {a }}$ Dr. ${ }^{\text {a }}$ Eloísa Pereira Barroso

Universidade de Brasília (UnB) - Presidente

Prof. ${ }^{\mathrm{a}}$ Dr. ${ }^{\mathrm{a}}$ Karina e Silva Dias

Universidade de Brasília (UnB) - Membro efetivo interno

Prof. $^{a}$ Dr. ${ }^{\text {a }}$ Magda de Lima Lúcio

Universidade de Brasília (UnB) - Membro efetivo externo

Prof. $^{\text {a }}$ Dr. ${ }^{\text {a }}$ Marutschka Martini Moesch

Universidade de Brasília (UnB) - Membro suplente interno 


\section{AGRADECIMENTOS}

E assim os anos foram se passando, até a decisão de realizar o Mestrado, antigo sonho, após inúmeros adiamentos injustificáveis. E quando eu pensei que havia perdido no tempo a chance de enveredar por uma nova seara de conhecimento, as palavras de minha Mãe, de quem herdei o nome, repercutiram: "Saber não ocupa lugar".

Meus agradecimentos se dirigem àqueles dois que me deram a oportunidade de estar aqui e agora, que me ensinaram a valorizar cada momento e conquista. Seu Artur e D. Nega (ambos in memorian), que sempre deram como opção primeira aos seus 15 filhos os estudos, na dificuldade da labuta diária no comércio na pequena cidade mineira de Cristiano Otoni.

Aos meus irmãos, Das Graças, Roberto, Dodora, Dulce, Tureca, Sérgio, Fernando, Leda, Regina, Celia, Paulo, Zé Flávio, Miguel, Flávia e demais familiares, dentre os quais incluo Ana Claudia, pelo carinho, pela torcida e compreensão, em relação às constantes ausências da rotina familiar, para dedicação à pesquisa.

À minha orientadora Eloisa Barroso, pelo acolhimento, estímulo à pesquisa, pelos conhecimentos compartilhados, pela dedicação e seriedade de seu trabalho.

Aos professores da UnB, Denize Silva, Francisca Cordélia, Luiz Martino, Luiz Spiller, Mario Beni, Marustschka Moesch, Neio Campos e Neuza Araújo, pela luxuosa colaboração nesta viagem pelo conhecimento. Aos demais mestres, cujos ensinamentos vêm me acompanhando, desde o ensino primário e dos quais recordo com carinho, Ana Lúcia Souza, Antônio Kattah (in memorian), Ataulfo Cardoso (in memorian), Cristina Magela, Dulce Oliveira, Efigênia, Eneida, Fernando Limoeiro, Fernando Linares, Francisco Pontes de Paula Lima (in memorian), Eduardo (in memorian), Gamela (in memorian), Geraldo Vidigal (in memorian), Ítalo Mudado (in memorian), Ivanete, Lúcia, Marilene, Moacir, Myriam Tavares, Sueli, Vanilda, Vera, Wenceslau Coimbra, Zequinha Laporte, e, de modo muito especial, D. Avelina Noronha, que confiou plenamente em minha capacidade de escrever e incentivou-me para a conquista de premiação no Ministério da Educação, quando ainda cursava o segundo grau.

Aos professores-doutores Daniela Fantoni e Hila Rodrigues, pelas cartas de apresentação, e Karina Dias e Cléria Botelho, pelas preciosas dicas quando realizada a qualificação do projeto.

Aos colegas de Mestrado da UnB, das turmas da Comunicação, da Linguística e do Turismo, por terem divido comigo momentos de reflexão e aprendizagem. E à ajuda constante dos membros da Secretaria do CET, Agatha, Luiz, Suely e Tatielle. 
Aos meus amigos queridos, dos quais é impossível nominar um a um. A todos vocês, indistintamente, que desde a mais tenra idade e ao longo desta caminhada mundo afora seguem comigo em pensamentos, palavras, ações e muitos sorrisos.

Aos colegas de trabalho, em especial Tadeu Figueiró, pelo incentivo incondicional, Paula Sayão, Patrícia Lira e Andréa Ribeiro, pela colaboração.

E, finalmente, ao Banco do Brasil, por meio da Gepes e de sua Universidade Corporativa, pelo apoio concedido para a realização deste Mestrado. 


\section{Resumo}

Esta dissertação resulta de uma pesquisa de natureza qualitativa (descritiva e interpretativa) cujo objetivo é analisar como o discurso produzido nas mídias sociais transforma o Centro Cultural Banco do Brasil Brasília (CCBB) em um destino turístico a partir da categoria hospitalidade. O trabalho aborda a constituição do espaço no imaginário do visitante e a relação com seu principal mecenas, o Banco do Brasil, principal instituição financeira do País e pioneira na criação de centros culturais corporativos. Estuda também o sucesso e a consolidação do empreendimento cultural, bem como a estratégia do espaço de manter proeminência no cenário turístico da capital federal por meio da exibição de artes.

O método utilizado é o da Análise do Discurso, com base no contexto das formações discursivas e no funcionamento da linguagem enquanto exercício do poder, como apregoa Foucault. As análises buscam os rastros de hospitalidade deixados no discurso proferido pelo CCBB Brasília no site e no Facebook. Das produções de texto online (posts) contidas nessas duas plataformas virtuais foram coletados os objetos de observação.

Os resultados alcançados na pesquisa sugerem que o anfitrião exercita seu poder, ao mesmo tempo em que convida seu frequentador (turista, visitante) a torna-se, ele mesmo, no espaço do outro, um hospedador. Ao fazer-se mecenas de um destino turístico, a mais longeva instituição financeira do País, por meio da linguagem, corporaliza seu símbolo dentro da cultura, instituindo uma relação com o turista.

Palavras-chave: Turismo. Hospitalidade. Discurso. CCBB. Internet. 


\begin{abstract}
This dissertation is the result of qualitative research approach (descriptive and interpretative) and aims to interpret how discursive practices at social midia transform the Centro Cultural Banco do Brasil Brasília (CCBB) into a touristic destination from Hospitality. This study approaches the construction of the space at the visitor's imaginary and its relation with its main sponsor, Banco do Brasil, the main Brazil's financial institution and pionner at the criation of corporative cultural centers. This study also notices the success and consolidation of cultural enterprise, as an strategy of the space to maintain itself as a prominence at the federal district's touristic scene by arts exhibitions.

The method used is called Speech Analysis, based on the discourse formations context and based on operation of language as exercise of power, like said Foucault. The analyses searches the hospitality trails left on the speech uttered by CCBB Brasília at its site and Facebook.

The reached results suggest that the host exercises his power, at same time that invites his guest (tourist, visitor) to become himself a host, in a space which belonges to others. By making itself Maecenas of a tourist destination, by the language, the long-lived financial Brazilian institution incorporates its symbol inside culture, instituting a relationship with tourists.
\end{abstract}

Keywords: Tourism. Hospitality. Discourse. CCBB. Internet. 


\section{LISTA DE ILUSTRAÇÕES}

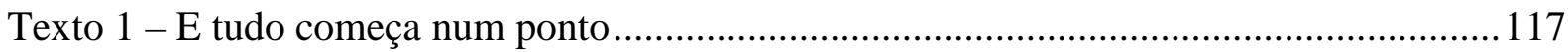

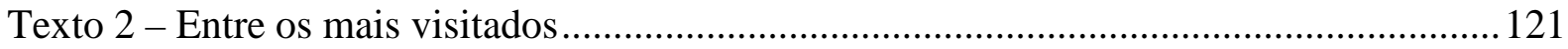

Texto 3 - Informações da página - Descrição Curta.............................................................. 122

Texto 4 - Informaçõ̃es da página - Descrição Longa ......................................................... 123

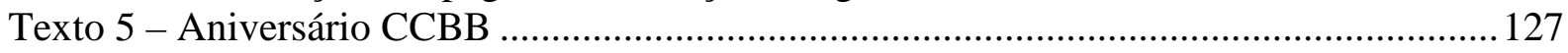

Texto 6 - Festival Moacir Santos + Meditação da Lua Cheia .............................................. 129

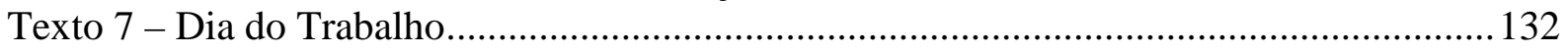

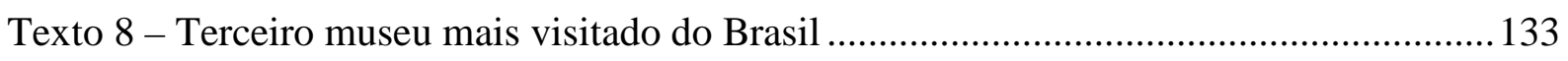

Texto 9 - A experiência da arte - série arte para crianças ................................................. 135

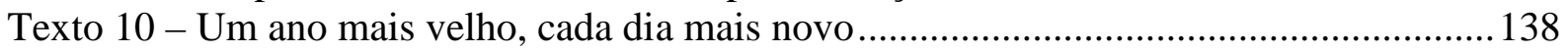

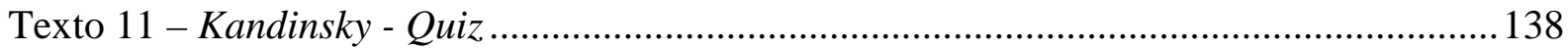

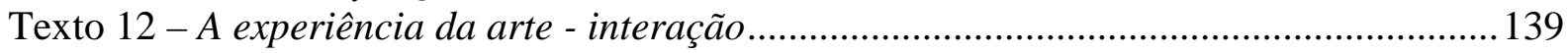

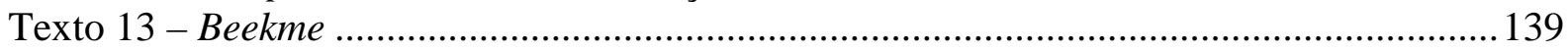

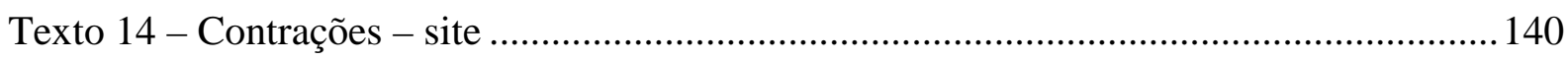

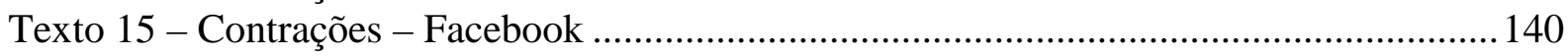

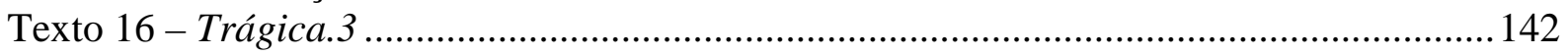

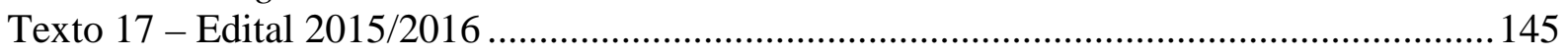

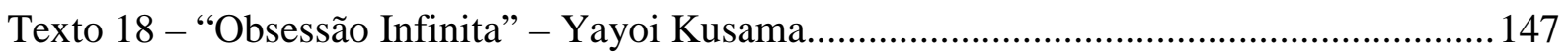

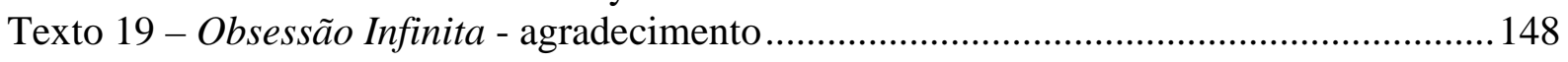

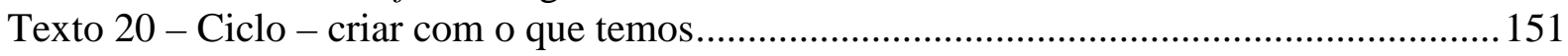

Texto 21 - Fantasma de Eguchi, de Petah Coyne................................................................ 153

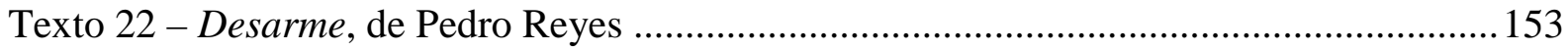

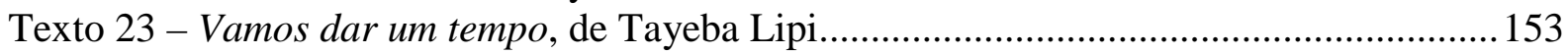

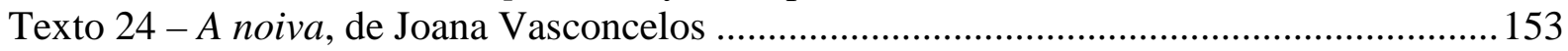

Texto 25 - Modelo para a sobrevivência, de Julia Castagno................................................ 153

Texto 26 - Slogans para o século 21, de Douglas Coupland................................................ 154

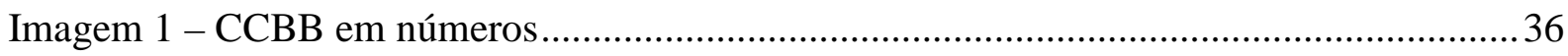

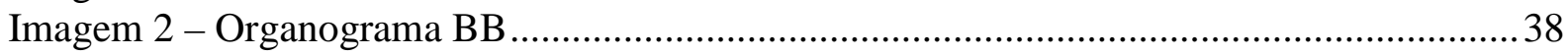

Imagem 3 - Maquete do projeto original de Oscar Niemeyer para o Cefor ......................... 173

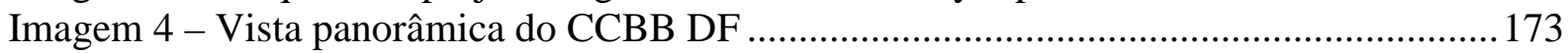

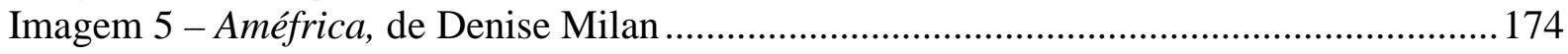

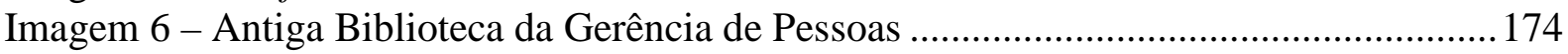

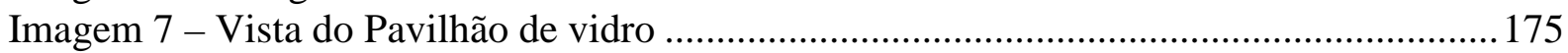

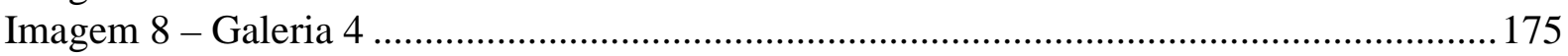

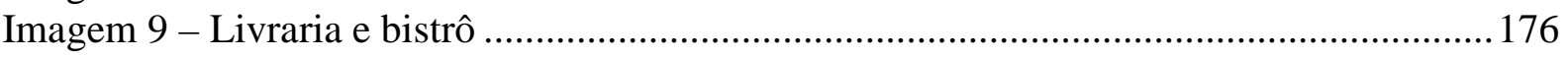

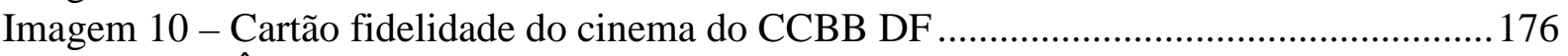

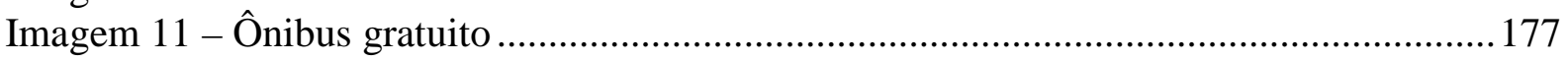

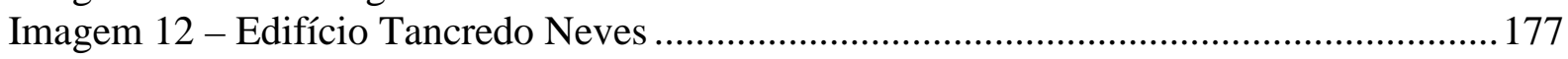




\section{LISTA DE ABREVIATURAS E SIGLAS}

$\begin{array}{ll}\text { AD } & \text { Análise de Discurso } \\ \text { ADC } & \text { Análise de Discurso Crítica } \\ \text { BB } & \text { Banco do Brasil } \\ \text { CCBB } & \text { Centro Cultural Banco do Brasil } \\ \text { CCBB BH } & \text { Centro Cultural Banco do Brasil Belo Horizonte } \\ \text { CCBB DF } & \text { Centro Cultural Banco do Brasil Brasília } \\ \text { CCBB RJ } & \text { Centro Cultural Banco do Brasil Rio de Janeiro } \\ \text { CCBB SP } & \text { Centro Cultural Banco do Brasil São Paulo } \\ \text { CCU } & \text { Global Council of Corporate Universities } \\ \text { Cefor } & \text { Centro de Formação do Banco do Brasil } \\ \text { Dimac } & \text { Diretoria de Marketing e Comunicação } \\ \text { Dined } & \text { Diretoria de Negócios Digitais } \\ \text { Direm } & \text { Diretoria de Estratégia da Marca } \\ \text { DMTU } & \text { Departamento Metropolitano de Transportes Urbanos } \\ \text { Fipe } & \text { Fundação Instituto de Pesquisas Econômicas } \\ \text { MinC } & \text { Minitério da Cultura } \\ \text { OMT } & \text { Organização Mundial do Turismo } \\ \text { ONU } & \text { Organização das Nações Unidas } \\ \text { UniBB } & \text { Universidade Corporativa Banco do Brasil }\end{array}$


SUMÁRIO

LISTA DE ILUSTRAÇÕES .........................................................................................9

LISTA DE ABREVIATURAS E SIGLAS ..............................................................................10

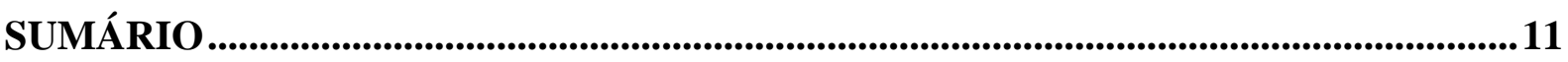

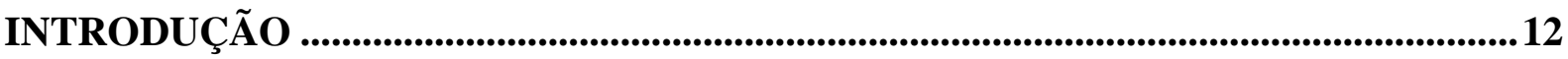

CAPÍTULO 1 - ESTUDOS SOBRE UM FENÔMENO INVENTADO ..............................17

1.1 FENÔMENO CONTEMPORÂNEO ……………………………………………………. 23

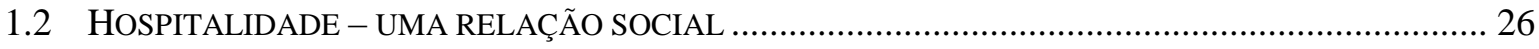

1.3 O TURISMO NA CONTEMPORANEIDADE: UMA COMPLEXA COMBINAÇÃO DE ELEMENTOS

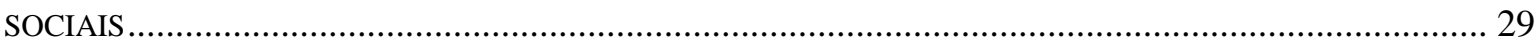

CAPÍTULO 2 - NA ORIGEM - UM ESPELHO DAS METRÓPOLES ............................36

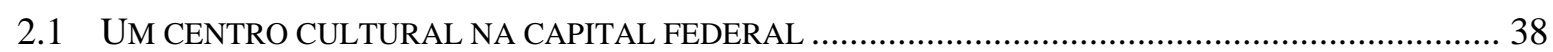

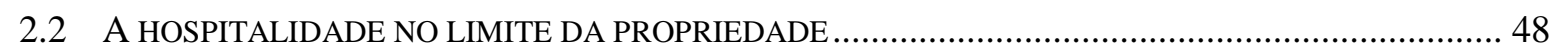

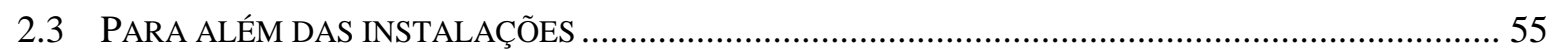

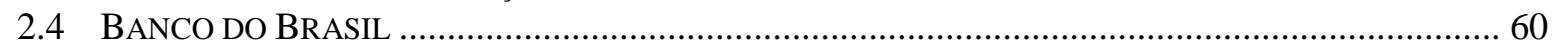

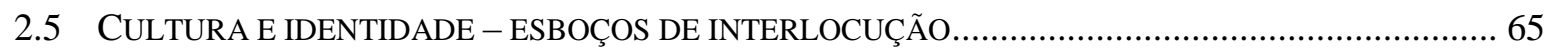

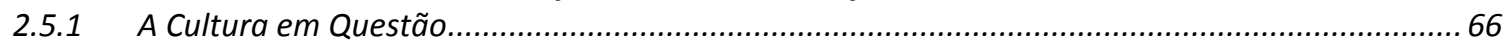

2.5.2 Princípio de identidade na hospitalidade do Centro Cultural ..................................................... 75

CAPÍTULO 3 - ESPAÇO - ÂNIMA LOCAL .....................................................................81

CAPÍTULO 4 - MECÂNICA DAS REDES .....................................................................89

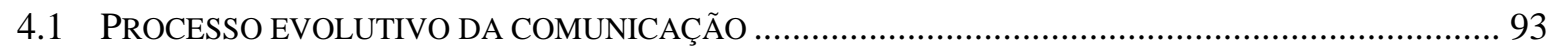

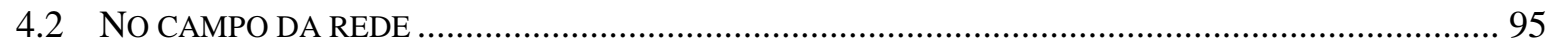

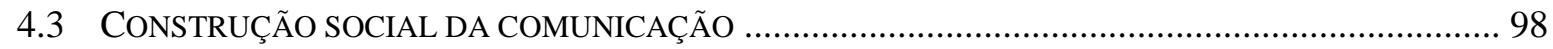

CAPÍTULO 5 - UM CAMPO DE PRÁTICAS HISTÓRICO-SOCIAIS ..........................104

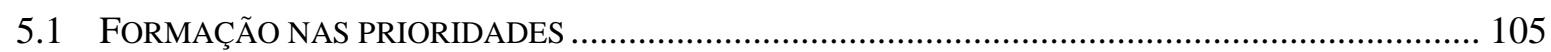

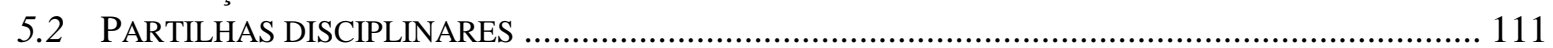

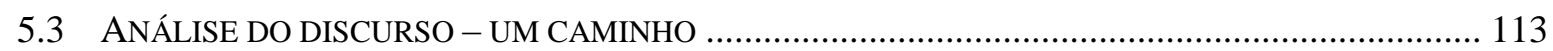

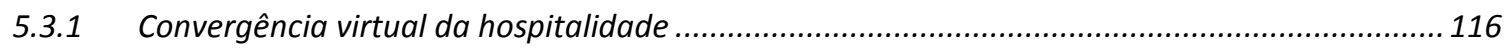

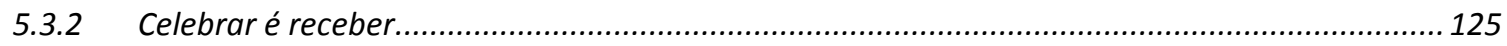

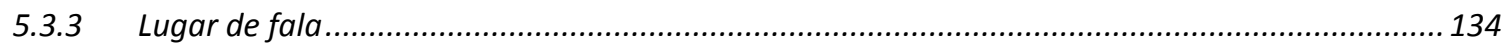

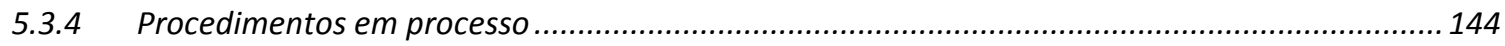

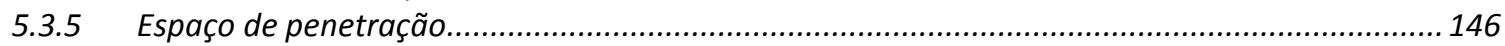

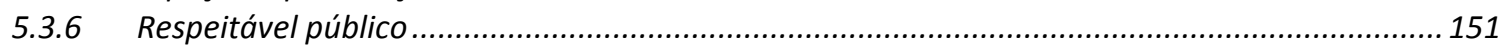

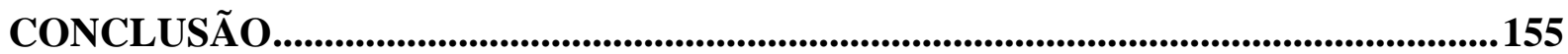

REFERÊNCIAS .............................................................................................................163

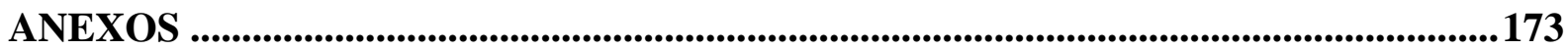




\section{INTRODUÇÃO}

O universo acadêmico está rodeado de perguntas. Os cânones da ciência moderna já não respondem mais aos problemas que se apresentam ao pesquisador. Há um limite epistemológico estabelecido, quando o determinismo mecanicista, do ordenamento, se desmorona. $\mathrm{O}$ aparente tempo não pode ser simplesmente separado do espaço, assim como o sujeito de seu objeto. Os paradigmas estão em discussão tanto quanto os fenômenos estudados.

Boa parte de nossas noções contemporâneas sobre a liberdade de expressão advém diretamente do Iluminismo. Na história oficial, os iluministas travaram dura batalha contra o Estado; mas cabe recordar que, acima de tudo, o desafio era a Igreja, ao colocar em xeque sua aspiração de controlar o pensamento, impondo-lhe limites - como exemplo, tome-se $L a$ Religieuse, romance de Diderot. Acreditar, porém, que toda essa contenda esteja ganha é uma falácia.

Como nos lembra Edgar Morin (2011), a visão cartesiana separou quem pensa da coisa pensada. Essa ruptura entre sujeito e objeto impôs ao pesquisador um paradigma que, aos poucos, vem sendo repensado. Há estudiosos que apregoam a importância da integração entre ambos, no intuito de produzir um conhecimento pertinente e condizente com o universo em sua perfeição e irregularidade.

Não se deve crer, no entanto, que o passado é dispensável. É primordial que este seja assumido, juntamente com a sabedoria nele produzida, pois o futuro, o conhecimento novo, ainda é um lugar desconhecido, que precisa ser construído e povoado. O momento é de voltar à Grécia para buscar a razão e chegar ao presente com a complexidade que lhe é inerente.

Nesse emaranhado de ideias, esta pesquisa apresenta referenciais que embasam os estudos para uma proposição que pretende, utilizando como método a Análise de Discurso (AD), analisar como o discurso do Banco do Brasil, por meio dos textos inseridos no site (www.bb.com.br/cultura) e em sua página no Facebook (www.facebook.com/ccbb.brasilia), transforma o Centro Cultural Banco do Brasil Brasília (Centro, CCBB, CCBB DF ou CCBB Brasília) em um destino turístico, a partir da categoria hospitalidade. Adverte-se, de antemão, que respostas não serão encontradas, mas inúmeras perguntas imiscuídas nas formulações em constante processo de construção, de encontro com suas bases e epistemes.

A busca pelo saber passa pelo conhecimento científico, cujo método pertinente para a investigação do que se deseja conhecer indica a direção e as regras a serem adotadas, a fim de se validar a discussão inserida no problema de estudo. E a análise de discurso (AD) foi a 
metodologia pela qual observou-se o objeto desta pesquisa, em que a linguagem adotada pelo CCBB constrói o espaço como lugar de visitação e o divulga enquanto destino turístico na conquista e atração do público.

É preciso deixar claro, como alerta Orlandi (2013), que a AD se interessa pela língua e pela gramática, mas não trata de nenhuma das duas. Sua preocupação é para com o discurso, “palavra em movimento, prática de linguagem”. E quem fala detém o poder. Contudo, esse poder não pertence ao indivíduo que redige o texto, em si, mas a um ente que controla as práticas sociais em um espaço concebido para se exercitá-lo.

E o Banco do Brasil, por meio de um linguajar de informalidade, penetra no espaço turístico pela categoria hospitalidade, materializando seu símbolo a partir de um espaço que abriga projetos culturais, atraindo públicos diversos. É onde laços de sociabilidade são reorganizados e o poder da porta é reforçado. A "alma do lugar" (YÁZIGI, 2001), cultivada nos textos, deve ser preservada, pois é ela a responsável pelo reconhecimento do CCBB como lugar de visitação e acolhimento.

E tudo começa pelo discurso produzido nas páginas de seu site e Facebook. A linguagem é voltada para a acolhida do turista, que, de convidado principal, torna-se, ele mesmo, anfitrião, pelas próprias questões que norteiam o CCBB em termos de hospitalidade, sendo a principal a importância de o indivíduo exercer o direito de ser turista dentro de sua própria cidade.

O turismo é uma atividade econômica sustentável, reconhecido pela prestação de serviços nas mais diversas vertentes que primam pelo lazer, pelo entretenimento, pela utilização do ócio, do tempo livre do trabalhador assalariado. No âmbito das ciências, é um fenômeno inventado, de vasto campo a ser descoberto e sobre o qual "o mínimo que se pode dizer [...] é que envolve movimento de um lugar para outro" (GRABURN, 2009, p.31).

A reflexão aqui realizada parte do princípio de que o mundo vive sob o efeito de inferências. Acredita-se que é o método escolhido pelo investigador que vai auxiliá-lo na árdua tarefa de encontrar as chaves para o que procura. Daí a divisão do trabalho ser em etapas, assim denominadas por ser este um percurso, um caminho percorrido de um ponto ao outro do conhecimento.

No Capítulo 1 - ESTUDOS SOBRE UM FENÔMENO INVENTADO, inicia-se o percurso da construção do Turismo como um campo de práticas histórico-sociais. Como incipiente ciência, este fenômeno peculiar se impõe com suas variáveis, a determinar o caráter do espaço como lugar de acolhimento. A abordagem prossegue pelas origens da prática turística, sua relação com o desenvolvimento do capitalismo, com o trabalho assalariado, o 
valor do ócio e a importância do deslocamento, para o estabelecimento de fluxos. De base intrinsecamente social, sua prática promove encontros, daí a relevância da categoria Hospitalidade, cuja complexidade passa pelo direito sagrado de receber e ser recebido, condição existencial de um ambiente situado entre o público e o privado, nascido da multiplicidade e do somatório das dinâmicas socioculturais, como é o CCBB Brasília. A condição social do bem receber motiva a visitação e a própria capacidade e vontade do hóspede em ser ele mesmo anfitrião no espaço do outro.

No Capítulo 2 - NA ORIGEM - UM ESPELHO DAS METRÓPOLES, os faróis se voltam para as condições sócio-político-econômicas, que propiciaram a criação do CCBB no Distrito Federal. O Centro é um lugar para onde as pessoas se deslocam para acompanhar seu calendário próprio de eventos, por meio do qual extrapola sua função de polo atrativo, posto que se trata de espaço dotado de infraestrutura com programação qualificada, sedimentado no pilar da interseção informação-cultura-turismo-consumo-turista. O visitante ainda é convidado a tornar-se, ele mesmo, anfitrião. Nesse ínterim, o CCBB constrói sua identidade enquanto lugar de hospitalidade para grupos e indivíduos, tornando-se espaço para a prática turística na concepção proposta por Mário Beni, já que, para o professor, "turismo é você propiciar ao turista a experiência de ser protagonista" (BENI, 2014).

No Capítulo 3 - ESPAÇO - ÂNIMA LOCAL, a reflexão sobre espaço, paisagem, território e lugar, à luz de Milton Santos, reconhece o ambiente como produtor de algo singular, que existe em função de construções de memória coletiva - e tal se dá, em função de sua apropriação pelo cidadão. O turista/visitante do CCBB DF ressignifica os espaços, enquanto o Centro, como anfitrião, adapta-se a essa necessidade.

No Capítulo 4 - MECÂNICA DAS REDES, a relação entre anfitrião e convidado é estabelecida, por meio de plataformas virtuais de comunicação, cuja base é o uso da tecnologia, por meio das redes sociais, equipamento que marca a organizada sociedade moderna. Como alerta Castells, a internet é o símbolo do funcionamento das redes e esta se relaciona a contextos associados ao poder de quem detém o lugar de fala. Em pauta, "a comunicação, predominante no fenômeno turístico, [que] visa tocar o outro, favorecer o contato com o outro, seja direta ou indiretamente" (MOESCH, 2002, p. 41).

No Capítulo 5 - UM CAMPO DE PRÁTICAS HISTÓRICO-SOCIAIS é realizado o exame dos dados selecionados, com base nos referenciais teóricos abordados no decorrer da pesquisa. Observa-se que o discurso está presente no social; não trata de simples transmissão de informação nem de um processo linear, onde um fala e o outro decodifica a mensagem; nesse ínterim, reside o simbólico. Para refletir sobre como essas relações se materializam no 
discurso proferido pelo Banco do Brasil, foram selecionadas duas plataformas distintas: a atuação no site e no Facebook, entre abril de 2014 e abril de 2015, período em que o CCBB Brasília, mesmo ampliando seu público visitante, passou de segundo para terceiro centro/museu mais visitado do Brasil, conforme levantamentos da publicação inglesa The Art Newspaper.

O diálogo que se estabelece com Foucault sobre as relações de poder embasam a reflexão sobre de que maneira "discurso" e "linguagem" se concentram no coração das práticas e dos processos sociais modernos. O CCBB DF, por meio do discurso, apresenta-se como fomentador de cultura, um mecenas, apropriando-se de um linguajar informal para penetrar no espaço, materializando seu símbolo dentro de outros universos, dentre eles o turístico. Reside, aqui, a necessidade de compreensão da concepção e da composição do lugar, a partir de uma identidade edificada por questões formuladas e para as quais espera-se obter resposta pela metodologia proposta: o CCBB Brasília foi criado a partir do quê, por quem, para quem e para o quê. Tudo isso para além do significado simbólico de trazer para seu domínio - o Centro enquanto lugar físico, no qual há possibilidade de controle sobre a frequência dos turistas que o visitam. E, assim, o CCBB DF, ao mesmo tempo faz de si mesmo um destino, um lugar de encontro para o turista-cidadão, culturalmente integrado aos propósitos ideológicos de quem o criou.

Na última parte, CONCLUSÃO, são apresentadas considerações relevantes sobre as reflexões realizadas ao longo das diferentes etapas, com destaque de como a linguagem materializa o símbolo Banco do Brasil dentro da cultura e, por meio dela, do turismo e da hospitalidade.

Cabe registrar o fato de a pesquisa ser realizada por funcionária do Banco do Brasil, que já atuou no Centro Cultural Banco do Brasil Brasília. Com o objetivo de manter distanciamento em prol das análises, buscaram-se informações que sempre estiveram disponíveis ao público, seja por meio da internet ou em impressos encontrados nos arquivos públicos e nas bibliotecas. A pesquisa foi iniciada com a coleta de publicações da página do CCBB Brasília no site e no Facebook. Paralelamente, desenvolvia-se estudo sobre a metodologia a ser aplicada, um diferencial dentre as costumeiramente utilizadas no Mestrado Profissional de Turismo da Universidade de Brasília. Desse modo, o cuidado na reunião de material para a análise era ainda mais criterioso, sem apontar defesas veementes para um ou outro campo de atuação.

Outra pontuação a ser considerada é a de que esta pesquisa tem meramente o objetivo de evidenciar práticas discursivas materializadas nos textos que compõem o corpus analisado, 
com base no referencial teórico abordado. Em nenhum momento houve a pretensão de esgotar o assunto. O tema é por demais complexo e abrangente e pode e deve ser locupletado por distintas visões. 


\title{
CAPÍTULO 1 - ESTUDOS SOBRE UM FENÔMENO INVENTADO
}

\author{
“Nem aos impérios nem aos homens será dado o tempo necessário para que aprendam à custa de seus \\ próprios erros. Onde quer que um tecelão remende seu pano, onde quer que o artista retoque sua obra-prima \\ ainda imperfeita ou apenas danificada, a natureza prefere repartir sem intermediários a argila e o caos, e esse \\ mesmo esbanjamento é o que denominamos a ordem das coisas.”
}

Marguerite Youcenar

O turismo é uma atividade econômica sustentável, com papel preponderante no desenvolvimento de comunidades, cidades, indivíduos, instituições. Como partícipe do mercado de trabalho, é reconhecido pela prestação de serviços nas mais diversas vertentes que primam pelo lazer, pelo entretenimento, pela utilização do ócio, do tempo livre do trabalhador assalariado. No âmbito das ciências, o Turismo é um vasto campo a ser descoberto, com a relativização dos modelos epistemológicos, como apontam os mais diversos estudos críticos. O turismo enquanto prática social integra um dos pilares do Turismo observado como fenômeno social.

A história nos mostra que não existe uma única verdade. Há a oficial, a dos oprimidos, a dos opressores, a dos observadores - e a dos fatos. Verdades são relativas e múltiplas, constituídas a partir da construção que delas se faz. A complexidade dessas tramas estabelecese, ainda, no ato da prática do turismo, ou seja, na experiência turística. Com isso, não se pode deixar de pensar no Turismo, enquanto ciência, como um grande sistema composto e multiforme. O Turismo traz consigo uma realidade social, cultural, econômica e política estabelecida em um território e, que, portanto, vai obedecer à lógica e às possibilidades desse espaço. Por outro lado, e ao mesmo tempo, faz-se necessário perceber que esse recorte de conhecimento não é um princípio isolado. E quem nos conta isso é, novamente, a História.

\footnotetext{
Várias são as formas com as quais a verdade pode ser instituída. Os efeitos de sentido que se colocam nos discursos produzidos em uma determinada sociedade são responsáveis pelas representações do imaginário construídos em uma época. Abordar os discursos como acontecimento, tanto o sociológico quanto o literário, significa assim apreender sentidos produzidos para a articulação de compreensão desse espaço urbano. [...] (BARROSO, 2008, p.81)
}

Desde o começo do século XX, cientistas vêm elaborando definições de Turismo, sem, contudo, chegar, cem anos depois, a uma conclusão sobre um único significado quanto ao que vem a ser esse fenômeno. A busca pelo entendimento de seu fluxo, talvez mais até que por sua definição, instiga cientistas a retornarem ao século XVI, quando nobres ingleses 
começaram a se movimentar pelo continente europeu, estimulados pela educação (conhecer Roma e outras praças era adentrar a história) e posteriormente pelo prazer de usufruir das montanhas, praias e águas termais (antes consideradas apenas medicinais).

O turismo foi inventado. As primeiras antecipações datam do século 16, com alguns viajantes humanistas que tiveram curiosidade pela Itália e o apetite pela Antiguidade. Montaigne é o arquétipo destes viajantes. As grandes descobertas datam do século 18: propus chamar o seu conjunto de Revolução Turística. Surgiram então o amor pelo campo, que se tornara lúdico, a transformação das práticas populares de uso das águas no termalismo mundano das estações termais que se estendeu até os balneários oceânicos, o novo desejo de ir aos limites e as invenções sucessivas das Geleiras, do Mont Blanc e do alpinismo e, enfim, a longa temporada de inverno no sul da França. O Romantismo prolongou estas invenções com sua descoberta do exotismo no tempo e no espaço. (BOYER, 2003, p. 19)

"Tempo" e "espaço" integram a primeira definição teórica do Turismo, concebida pela Sociedade das Nações, em 1937: "Toda a pessoa que viaja durante 24 horas ou mais por qualquer outro país distinto da sua residência habitual” (apud MOESCH, 2004, p. 22). Sabese que todo conhecimento é produzido com uma intencionalidade, e o da Sociedade das Nações era o de elaborar estatísticas. Com dados disponíveis, construiu uma tipificação do que viria a ser o turista, utilizando o método hipotético-dedutivo. O objetivo era contar, contabilizar esse turista e entender um movimento que era então observado, o do trânsito de pessoas.

Nos anos compreendidos entre 1920-1940, época do entre guerras, procurava-se entender quem eram aquelas pessoas associadas às classes trabalhadoras que circulavam - em números expressivos - entre países. A Europa tinha condições sociais e econômicas para nutrir esse fluxo, não somente por causa das viagens dos ingleses ao continente, mas também pela já presente burguesia francesa, além dos direitos trabalhistas existentes, especialmente por parte do sistema industrial, que passava a ordenar o tempo trabalhado e o destinado ao descanso. Cabe destacar que, mais tarde, com esse tempo diferenciado - trabalho e férias remuneradas - seriam criadas as condições objetivas para a existência de viagens voltadas para o turismo. Alguns autores, dentre eles Moesch, defendem que o Turismo só existe dentro desse processo de surgimento do capitalismo e evolução do capital, justamente pelas condições de trabalho e remuneração que permitiram ao mesmo tempo a sobrevivência dos trabalhadores e seus familiares e o uso desse tempo livre, de férias.

A evolução do Turismo internacional, objeto de estudos da OMT (1998), cresceu quase ininterruptamente ao longo do tempo, aumentado também nos 
períodos do auge econômico (lê-se do capitalismo), oscilando o seu crescimento nos períodos de recessão, e recuperando-se quando passava a crise econômica, o que permite aos estudiosos da OMT concluir que a atividade turística está claramente influenciada pelo crescimento econômico. (MOESCH, 2004, p.41)

Em 1954, portanto, dezessete anos mais tarde da conceituação inicialmente dada pela Sociedade das Nações, turista, para a Organização das Nações Unidas (ONU), sofreu alguma alteração, passando a ser definido como qualquer pessoa que ingressasse em local diverso de sua residência, nele permanecendo entre $24 \mathrm{~h}$ e seis meses ao longo de um ano, com qualquer finalidade (turismo, estudo, lazer, família, saúde, negócios), exceto imigração.

É também sob essa perspectiva que a Organização Mundial do Turismo (OMT), herdeira oficial dos estudos estatísticos, orienta o setor turístico mundial, bem como as pesquisas sobre demanda e oferta turísticas. Em 1994, mantendo suas formulações a partir das orientações dadas pelo paradigma dominante da ciência moderna, define:

[...] o Turismo compreende as atividades realizadas por pessoas durante suas viagens e permanências em lugares distintos ao seu entorno habitual, por um período de tempo consecutivo inferior a um ano, com fins de ócio, negócios e outros. (NACIONES UNIDAS, ORGANIZACIÓN MUNDIAL DEL TURISMO, 2000, p.7) ${ }^{1}$

Essa categoria da pessoa que viaja por um curto período de tempo tornou-se o conceito basilar de turista para a OMT, que emprega:

[...] uma metodologia científica para o estudo do Turismo, referindo-se pura e simplesmente, ao longo dessas décadas, aos estudos estatísticos de demanda e oferta, elaborados a partir de fatos empíricos contatados ao longo dos anos, refletidos nas economias internacionais, principalmente européias e norte-americana, pós Segunda Guerra Mundial. (MOESCH, 2004, p. 36)

E todo e qualquer dado é tomado como número passível de ser enquadrado e mensurável no modelo adotado pela entidade internacional, segundo a qual

O turismo é um fenômeno social, cultural e econômico relacionado com a movimentação de pessoas para lugares que se encontram fora de sua residência habitual por motivos pessoais ou de negócios/profissionais. Essas pessoas se denominam visitantes (que podem ser turistas ou viajantes; residentes ou não residentes) e o turismo tem a ver com suas atividades, das

\footnotetext{
1 “[...] el Turismo compreende las actividades que realizan las personas durante sus viajes y estancias en lugares distintos a su entorno habitual, por um período de tiempo consecutivo inferior a um año, con fines de ócio, por negócios y otros."(NACIONES UNIDAS, ORGANIZACIÓN MUNDIAL DEL TURISMO, 2000, p. 7)
} 
quais algumas implicam em gasto turístico. (NACIONES UNIDAS, ORGANIZACIÓN MUNDIAL DEL TURISMO, s/d $)^{2}$

Nesta definição, a OMT determina tipos de visitantes (aquele que viaja para um destino diferente do seu habitat cotidiano por menos de um ano e por qualquer motivo, exceto o de se empregar no local): "turista" (o visitante que pernoita), "excursionista" ou "visitante do dia" (quando não há pouso), "residentes" ou "não residentes". Na visão numulária da OMT, o consumo de bens e serviços, ainda que não seja uma condição para a existência do turismo, dele faz parte.

De acordo com Siqueira (2005), essas classificações como as apresentadas do turismo e do turista - e ela enumera diversas outras, como "institucionalizados", "peregrinos modernos", "buscadores de prazer" - são fruto da fragilidade da reflexão teórica verso o desconhecido. A tendência, segundo a autora, é a de adaptar o novo, o ignoto, dentro de uma lógica já sabida - e destaca a relevância da linguagem.

[...] A partir de nossas leituras da realidade, o desconhecido torna-se conhecido. O cérebro, em seu eterno fazer organizativo, incorpora, compreensivamente, aquilo que faça sentido em seu marco já existente de conhecimentos, daí a importância da linguagem. Ela possibilita a consciência daquilo que é estranho, desconhecido. [...] (SIQUEIRA, 2005, p. 82)

Foi na Inglaterra, que tem todo um arcabouço globalizante, devido à sua economia, à revolução industrial, que a primeira organização para o turismo se estabeleceu, com o objetivo de levar a população de um lado para o outro do arquipélago - ou mesmo para o continente.

A literatura do século XIX e do início do XX é pródiga em manifestações que atestam o gosto pelas viagens, cujo mote residia na crença de suas propriedades medicinais - vide "Casa de Bonecas", do norueguês Henrik Ibsen (1828-1906), ou "Morte em Veneza", do alemão Thomas Mann (1875-1975). Os textos, ainda que ficcionais e concebidos para o deleite dos amantes das letras, são exemplos da proliferação dos balneários, cujo desenvolvimento, nos séculos XVIII e XIX, tinha mote inicialmente apenas terapêutico.

[...] No século XIX o desenvolvimento dos balneários baseava-se nas supostas propriedades dos banhos de mar como restauradores da saúde. Os banhos de sol, ao contrário, eram relativamente inusitados, em parte devido ao grande valor atribuído à pele alva, que significava delicadeza, ócio e

\footnotetext{
2 "El turismo es un fenómeno social, cultural y económico relacionado con el movimiento de las personas a lugares que se encuentran fuera de su lugar de residencia habitual por motivos personales o de negocios/profesionales. Estas personas se denominan visitantes (que pueden ser turistas o excursionistas; residentes o no residentes) y el turismo tiene que ver con sus actividades, de las cuales algunas implican un gasto turístico." (NACIONES UNIDAS, ORGANIZACIÓN MUNDIAL DEL TURISMO, s/d)
} 
reclusão. Isso começou a mudar em relação às classes altas a partir de 1920, sobretudo graças ao desenvolvimento de novos balneários da moda, tais como Cannes e Biarritz [...]. (URRY, 1996, p. 60)

No pós-guerra, porém, o sol tomou o lugar do mar. E seguiram-se novos olhares sobre as montanhas, as paisagens, sobre o valor do ócio - este, até então inerente somente à nobreza, passou a integrar o cotidiano dos proletários assalariados da era industrial.

Antes de prosseguir neste importante marco de toda a estrutura do Turismo, o capitalismo, vale retomar Boyer (2003) e seu destaque para a etimologia da palavra. Segundo o autor, trata-se de um neologismo, cuja origem é aceita universalmente: a palavra anglosaxônica tourism pressupõe ida e volta, tendo sua origem na francesa tour e na italiana tornare, que significam dar a volta, retornar ao lugar de origem. Essa noção de deslocamento leva a considerações como a do mestre britânico Nelson Graburn: "O mínimo que se pode dizer do turismo é que envolve movimento de um lugar para outro.” (GRABURN, 2009, p.31)

Na Inglaterra, a partir do final do século XVII, o The Tour ou Grand Tour estruturava viagens para filhos da aristocracia em direção ao continente europeu, "os estudos sobre as viagens iam desde uma ênfase escolástica no turismo enquanto oportunidade para um discurso até o conceito de viagem como observação de um testemunho ocular" (URRY, 1996, p. 19).

Em 1851, a Exposição Internacional de Paris é a destinação da primeira viagem turística internacional, organizada na Inglaterra por aquele que é considerado o pioneiro, se não o "inventor", do moderno trade turístico, Thomas Cook. Essas exposições foram os primeiros marcos de uma civilização doravante globalizada econômica e culturalmente. Há uma cidade que convida o público a assistir a expositores de diferentes países que vêm mostrar o produto da sua criatividade e esperam futuras viagens dos visitantes.[...] (CAMARGO, 2011, p.19)

Acrescente-se que, do século XVIII ao século XX, os meios de transporte e de comunicação renovaram-se e as viagens encontraram condições cada vez mais favoráveis - e com elas a penetração do turismo em camadas sociais mais amplas. A revolução industrial, direta e indiretamente, inventou meios de locomoção (trem, automóvel) e estimulou o desenvolvimento de infraestruturas de circulação (de pessoas, de informações - jornais, livros, folhetos) e de hospedagem.

A evolução desse turismo, aliás, promoveu, não o surgimento, mas a evidenciação de como a hospitalidade operava de modo muito mais amplo do que se imaginava. E ela pode ser percebida em facilidades que o visitante passou a encontrar ao ingressar no espaço, seja de uma cidade, uma praça, um museu, um centro cultural ou afim. 
Uma sinalização que o faz sentir-se seguro e integrado é uma dessas premissas, cuja composição pode ser acrescida da qualidade na permanência, com prestação de serviços que favoreçam a escolha desse conviva, com opções de hotelaria, restaurantes e similares, para todos os bolsos e gostos, com transporte interno (ônibus, metrôs, táxis) que possibilite os deslocamentos no entorno. A variedade nas oportunidades de diversão e entretenimento em espaços fechados ou ao ar livre, em curtos deslocamentos para litoral, matas ou montanhas, com a alternativa de acompanhamento por receptivo local ou guia de agências de viagens integra esse arsenal.

$\mathrm{Na}$ visitação, esse que chega ao território do outro deve sentir-se incluído e adaptado ao ambiente. Para tanto, conta também com a educação e a capacitação dos profissionais e dos membros da sociedade que o recebem, numa construção de familiaridade, primeiro senso de acolhimento do ser humano. Na interpretação de Gilberto Freyre, dentro de casa é que se forja uma maneira de dialogar, amar, cozinhar, comer, educar as crianças, se relacionar com as pessoas, sofrer opressão e exercer o controle da situação. É parte desse cenário hospitaleiro que o visitante encontra no Centro Cultural Banco do Brasil Brasília.

[...] O que nomearia, de fato, a língua, a língua dita materna, aquela que carregamos consigo, aquela que nos carrega do nascimento à morte? Não parece aquele lar que não nos abandona nunca? O próprio ou a propriedade, pelo menos o fantasma de propriedade que, no mais perto do nosso corpo, e nós sempre ali voltamos, daria lugar ao lugar mais inalienável, uma espécie de hábitat móvel, uma roupa ou uma tenda? A tal língua maternal, não seria ela uma espécie de segunda pele que carregamos, um chez-soi móvel? Mas também um lar inamovível, já que ele se desloca conosco? (DERRIDA, 2003, p.81)

Em cada movimento dessa ruptura ou evolução, como prefere a maioria dos estudiosos sobre o tema (Camargo, Derrida, Dufourmantelle, Grassi, Montandon, dentre outros), o turista depara-se com a hospitalidade em suas mais diversas ramificações, pois essa categoria tornase muito mais evidente do que se pressupunha, sendo presença em todas as atividades relacionadas com o turismo. Como atesta a doutora em História e em Língua e Literatura francesa, Marie-Claire Grassi, "a hospitalidade é obrigatória" (GRASSI, 2011, p.47) e "gesto de autorização" (op.cit., p.48). Mas é, antes e acima de tudo, acolhida (Mauss, Montandon).

[...] Cabe frisar o sentido do verbo acolher, pois é observado nas atitudes hospitaleiras um forte desejo de querer receber, tratar ou até proteger bem o visitante, ou seja, o acolhimento é demonstrado para dar maior valor aos atos do bem receber. Os atos de acolhimento, ou melhor, o caráter hospitaleiro é um atributo especial para os que proporcionam a hospitalidade. [...] (NEVES e ALEXANDRE, 2006, p.4) 
A literatura reiteradamente afirma que a essência do turismo é a experiência e que os fluxos turísticos têm a ver com tempo, espaço, deslocamento, recursos (natureza, dinheiro).

\subsection{Fenômeno contemporâneo}

Foi a Inglaterra, país que promoveu, além das revoluções industrial, agrícola e financeira, a incipiente indústria turística (BOYER, 2003). Observa-se que foram condições objetivas de uma realidade que ali propiciaram: classe trabalhadora organizada, processo de alienação do trabalho - que Henry Ford colocaria no seu modelo da linha de montagem... Era o início do turismo organizado, como afirma Boyer. Trata-se de evidências sobre o quê e em quê se constituiria em uma concepção teórica. E como não poderia deixar de ser, surge, desde já, uma contradição relacionada ao materialismo histórico-dialético: ao mesmo tempo em que a revolução industrial estabelece melhores condições de trabalho, o proletário vai vender sua mão de obra. Em outras palavras, a indústria, enquanto aliena e escraviza, oferece, como ressalta Krippendorf (2003), um sistema de vida compensatório entre o trabalhar e o descansar - o que pressupõe lazer longe do trabalho, com deslocamento. Esse sujeito trabalhador precisa buscar o lugar em que vai descansar; mas, para isso, ele precisa receber salário, tanto para sua sobrevivência quanto para usufruir de suas férias, de seu tempo livre.

Para Boyer (2003), o consumo do turismo difere dos demais tipos de - desculpe a reiteração - consumo. Em primeiro lugar, porque se dá em outro local, que não o lar do consumidor, o seu próprio aconchego. Em segundo, porque não visa à satisfação de nenhuma necessidade fundamental do ser humano. A terceira justificativa, afirma o francês, é que "nenhum lugar é turístico em si" e "nenhum sítio merece ser visitado". Para ele, "o turismo é um produto da evolução sociocultural", cuja definição seria:

[...] conjunto dos fenômenos resultantes da viagem e da estadia temporária de pessoas fora de seu domicílio, na medida em que este deslocamento satisfaz, no lazer, uma necessidade cultural da civilização industrial. (BOYER, 2003, p. 16)

Essa relação intrínseca com a viagem e seu conceito - saída e retorno ao lugar de origem - é um aspecto que ainda induz cientistas a considerar o Turismo sob esse paradigma reducionista, à luz da conceituação da OMT. Deslocamento pressupõe dispêndio e, consequentemente, uso de dinheiro. Coube, portanto, aos economistas, inicialmente, notar a relevância da prática turística e da construção de sua concepção. 
Premissa aceita por diversos pesquisadores é a de que a experiência turística é uma característica da modernidade que confere status a quem a exerce (URRY, 1996, p. 19). Os estudiosos do Turismo se valem de observações como a de "empoderamento" para elucubrar sobre a intervenção capitalista na atividade:

Entretanto, vale dizer que nem a operadora mais competitiva do mercado turístico ousaria confessar que está interessada somente nos negócios. Nem sequer um manual de administração se atreveria a afirmar que no sistema comercial as pessoas somente existem como produtoras, consumidoras e mão de obra. (CAMARGO, 2010, p.135) ${ }^{3}$

Os acontecimentos da década de 1940, especialmente a chamada II Grande Guerra, abalaram os estudos epistemológicos empreendidos em Turismo. Os movimentos econômicos ocorridos no final das décadas de 1990 e 2000 também. Essas agitações nas estruturas dessas análises levam pesquisadores de diversas partes do mundo a ampliar o debate, incluindo, nas pesquisas, além de sua relação com a indústria, com a entrada de recursos e o crescimento dos empregos nos denominados polos turísticos, uma nova onda que oferece espaço para as temáticas dos grandes eventos e dos tipos de trabalhos inscritos nesses espaços de altercação. Em outras palavras, sai-se do campo da competitividade e entra-se no espaço do social, da construção de relações sociais, do acesso ao lazer, da movimentação "em" e "no" turismo. É nesse contexto que, nos anos 2000, o Centro Cultural Banco do Brasil Brasília vai emergir no Planalto Central e, em pouco tempo, solidificar-se como espaço de qualidade, bom gosto e hospitalidade, no qual todos os públicos são bem-vindos.

Em uma vertente histórica, com o advento do capitalismo, com a distribuição de renda, com a empregabilidade disponível ao cidadão apto e capacitado para o trabalho, as mais diversas classes sociais conseguem se organizar para as férias para usufruir com prazer de seu tempo livre. Tal fato vem tomando o olhar do pesquisador em Turismo. Afinal, para ser turista, já não é mais necessário sair de sua cidade.

Observa-se, contudo, que ainda é muito arraigado o olhar voltado para os estudos do turismo sob duas óticas: uma que o relaciona, necessariamente, a viagem, o chamado turismo formal, e outra que o determina como turismo alternativo - sendo este contextualizado a partir de dois movimentos: o dos residentes locais - envolve os excluídos do turismo formal e a valorização da cultura em bairros - e o que parte de turistas interessados em conhecer as chamadas comunidades tradicionais - quilombolas, indígenas, pesqueiras - ou seja, o turismo

\footnotetext{
3 "Sin embargo, vale decir que ni la operadora más predadora del mercado turístico osaría confesar que está interesada sólo en el negocio. Ní siquiera un manual de administración se atrevería a afirmar que en el sistema comercial las personas sólo existen como productoras, consumidoras y mano de obra." (CAMARGO, 2010, p.135)
} 
diferenciado em locais menos urbanizados. Muito se fala, portanto, em viagens e férias. $\mathrm{O}$ tempo livre, porém, aos poucos passa a ser considerado, posto demarcar as relações sociais e o próprio início do turismo.

De acordo com Molina (2003, p. 11): "O setor turístico é, em seus conceitos e práticas, geralmente conservador e pouco dado a identificar-se com novas teorias até que não tenham sido provadas." A afirmação do autor deve-se à defesa que faz do pós-turismo, conceito idealizado por ele, um modelo ainda em processo, e cuja base é "deixar de repetir para pensar, em superar o objeto supostamente conhecido, resolvido e concluído para retomá-lo e encaminhá-lo" (op.cit., p. 16). O pós-turismo seria uma realidade a ser decodificada.

Assim também a categoria hospitalidade, cuja complexidade (seu dever, seu direito, sua política, sua poética, sua ética, como a concebe Derrida) passa pela divindade, pelo sagrado direito de receber e ser recebido na realidade social e política.

O mito lança as bases da história da hospitalidade tal como ela se desenvolveu no Ocidente a partir da Grécia antiga, fazendo da hospitalidade o próprio signo de toda civilização. Esse caráter universal e humanista é um dos grandes fundamentos do conceito tal como ele se construiu ao longo dos séculos. Os mitos antigos como os mitos literários, os de Anfitrião, de Filêmon e Báucis tiveram um destino várias vezes milenar. (MONTANDON, 2011, p.713)

Na base, a mitologia grega, cujos escritos que chegaram até nós narram o apreço dos deuses pela hospitalidade, com recompensa para os hospitaleiros - como o casal Filêmon e Báucis - e castigo para os que praticam a inospitalidade - rei Licáon, da Arcádia (SCHWAB, 1994). Ao longo dos séculos, diversos autores recorreram às agruras e felicidades de um anfitrião, as virtudes e os vícios que envolvem a arte do acolhimento, propiciando ao público leitor ou espectador, risos e lágrimas. O tema, por sua relevância no contexto das mais diversas sociedades, é encontrado em obras escritas por ícones como Plauto e seu "Anfitrião", que inspirou a peça homônima de Molière, Shakespeare, o bardo de abordagens controversas sobre a hospitalidade, que vão da apresentação de rituais do bem receber da época às intrigas, com hóspede ilustre sendo assassinado por anfitriões, como o fazem Macbeth e sua Lady com o rei Duncan, em "Macbeth", apenas para citar uma de suas obras. No século XX, a citação recai sobre o controverso poeta e cineasta italiano Pier Paolo Pasolini que, em seu "Teorema", romance e filme de 1968, narra a chegada de um visitante que perturba completamente a ordem estabelecida. O CCBB Brasília sabe da importância de bem receber seu visitante, desde o modo de comunicar seus projetos ao último frequentador do dia. $\mathrm{Na}$ vida real e na ficção, paga um alto preço quem não trata seu hóspede com zelo. 


\title{
1.2 Hospitalidade - uma relação social
}

Percebe-se que a complexidade do Turismo se estabelece inicialmente desse emaranhado de condições e possibilidades, entre esse processo de construção do que vem a ser o desejo de estar em outro lugar, mas sempre com a intenção de se voltar para casa dentro de um curto período de tempo, nomadismo inerente ao ser humano, com a estada - que advém de uma característica cultural de hospitalidade. Mas tal lembrança ou associação não deve ser confundida com a hospitalidade originada nas antigas Grécia e Roma, onde a hospedagem era oferecida gratuitamente e quando receber um hóspede representava uma benção para o anfitrião.

\begin{abstract}
A hospitalidade deve ser pensada como muito mais do que receber, hospedar, alimentar e entreter. Pensada como uma relação social, onde o encontro de pessoas ou grupos de pessoas com vivências culturais diferentes determinam o ambiente hospitaleiro. Assim, pode-se avaliar a hospitalidade como sendo um comportamento interativo que estabelece a troca de benefícios mútuos para o anfitrião e do (sic) visitante. (NEVES e ALEXANDRE, 2006, p.6-7)
\end{abstract}

No turismo, fenômeno contemporâneo, não se pode esquecer, a hospitalidade está sob a ótica do capital. E é este que detém o poder da porta, de decidir quem pode ou não por ela passar. No Centro Cultural Banco do Brasil Brasília, o visitante adentra a soleira de uma porta simbólica, representada pela passagem da rua para os paralelepípedos que o introduzem ao espaço, placas indicativas sinalizam e direcionam o turista, que também se orienta pelos banners expostos ao longo de sua área externa e, em determinados casos, no próprio local expositivo. Para facilitar a locomoção, suprindo a deficiência do transporte público que serve a região, oferece ônibus gratuito, rapidamente identificável pelo público, posto estar sempre vestido com a marca do Banco e com a principal mostra no campo das artes visuais exposta no período. Outro modus operandi apresentado pela hospitalidade está na recepção, não do dono da casa, em si, mas por quem o representa: em se tratando de um centro cultural, bilheteiros, seguranças, técnicos do teatro, do cinema, das galerias, atendentes de serviços gerais e de limpeza. Nesse ambiente, as boas-vindas são terceirizadas, pois o anfitrião máster é impessoal e onipresente.

[...] o Turismo se constitui em um fenômeno sociocultural de profundo valor simbólico para sujeitos que o praticam. Simbólico porque as práticas realizadas, os produtos e serviços envolvidos significariam menos pelo seu valor venal ou valor de troca, e mais pelo seu valor de uso e pelo seu valor afetivo. Por isso, no turismo fala-se cada vez mais em experienciar, 
vivenciar e conviver, porque esses são os grandes mobilizadores do estranhamento. (GASTAL e MOESCH, 2007, p. 12)

É exatamente esse bem estar do turista, que busca experiências que transcendem seu cotidiano, que o CCBB procura oferecer por meio dos serviços que disponibiliza. A qualidade dessa oferta no destino turístico vai influenciar diretamente no conhecido maniqueísmo do bom ou mau atendimento ao visitante.

Aonde quer que vá, o turista espera encontrar hospitalidade, "sinal de civilização e de humanidade" (MONTANDON, 2011a, p.31). Pode-se depreender, com isso, que a perspectiva da hospitalidade está na natureza dos homens e dos espaços e a do CCBB Brasília não se limita simplesmente ao convite que faz, por meio do site, do Facebook, do Twitter, do livreto de programação e de outros meios. Ela está para além de sua capacidade de se expressar com palavras.

Tendo como mecenas uma instituição pública que, pela segunda vez consecutiva, é reconhecida pelo instituto norte-americano Ethisphere como uma das empresas mais éticas do mundo ${ }^{4}$, busca ser admirada. A opinião da era moderna acerca da esfera pública tem a ver com "admiração pública", com status, vaidade, e com "recompensa monetária" - ambas "têm a mesma natureza e podem substituir uma à outra”. (ARENDT, 2007, p.66)

Jardins, praça, edifício histórico - na condição de ter sido concebido por Niemeyer -, serviços gastronômicos, atrações culturais diversas e para todas as idades e trabalhadores dispostos a ajudar compõem o ambiente do CCBB DF. Receber bem, portanto, é uma condição existencial permanente face às circunstâncias sociais (seu patrono é um banco de economia mista; logo, ao mesmo tempo público e privado), às pressões da opinião pública (do espaço espera-se sempre o melhor e a demarcação do que é ou não arte, do que se produz atualmente nesse campo), aos valores impostos pelos meios de comunicação (a mídia está constantemente em busca de notícias, de novidades, de cases de sucesso) e às convenções acadêmicas (os projetos espelham os estudos desenvolvidos e os pautam). Esse "bem receber" vai motivar seu retorno ou não ao local visitado, sua vontade ou não de divulgar o espaço, seu carinho e atenção para com quem o recebe.

É nesse emaranhado turístico que uma pergunta se faz: o CCBB DF, por meio de seus canais de comunicação digital (Galáxia de Marconi), constrói e estabelece um discurso que

\footnotetext{
${ }^{4} \mathrm{O}$ BB é "o único banco da América Latina a figurar na lista das vencedoras [do Instituto Ethisphere, como uma das empresas mais éticas do mundo], que conta com apenas duas empresas brasileiras - BB e Natura". A premiação, concedida "anualmente, após análise das práticas corporativas, por meio de pesquisa com quase 200 questões", destaca a "excelência em controles internos, gestão do risco, cultura da ética, sustentabilidade e governança corporativa, com resultados em políticas de anticorrupção". (BANCO DO BRASIL, 2015)
} 
solidifica sua identidade como lugar de acolhimento e visitação? A questão, para ser respondida, clama por outras demandas investigativas, tendo em vista a interdisciplinaridade dos estudos turísticos e a metodologia escolhida, a análise do discurso, a qual pressupõe o poder do locutor, do detentor do lugar da fala.

Não se deve esquecer que há um mentor a balizar todas as ações do Centro Cultural Banco do Brasil Brasília e que este é, essencialmente, um ente cujas base e origem assentamse no polo financeiro. "Os recursos são a base de toda a indústria turística, quando transformados em atracções, e são a chave para a atractividade e crescimento do turismo." (AGÊNCIA DO ARADE, 2005, p. 10). Transportando a frase para a atuação do CCBB, temse o ambiente, a manutenção do espaço, com o oferecimento de programação disponível ao visitante durante seis dias por semana, gratuita, ou a preços acessíveis, serviços de gastronomia, limpeza, educacionais, e reiterado convite de boas-vindas diário, por meio de sua página no site e nas redes sociais. Mas como a linguagem adotada pelo CCBB constrói o espaço como lugar de visitação e o divulga enquanto destino turístico na conquista e atração do público?

O CCBB DF apresenta ao público, não somente artistas de renome nacional e internacional, mas também destaques da região em diversos segmentos - artes plásticas, artes cênicas, música, cinema - o que contribui para criar uma identificação com os residentes, ao valorizar a produção local. Nesse sentido, pratica a política da boa vizinhança, acolhendo aqueles que lhe são mais próximos.

As boas relações com a vizinhança e com o meio ambiente físico, que,
ancestralmente, se tornavam a referência mais comum para as cenas
hospitaleiras das famílias, são hoje valorizadas pela linguagem empresarial
como responsabilidade social para com o entorno, pela promoção de visitas
programadas às suas instalações pelos habitantes desse entorno [...].
(CAMARGO, 2011, p.22)

O CCBB acolhe com presentes. O Centro premia os visitantes mais assíduos com catálogos das mostras de cinema (retirados na bilheteria, mediante cartão fidelidade) e os clientes com convites especiais para pré-estreias, visitas guiadas, dentre outras ações de valorização do seu público. O fortalecimento do vínculo social gera "a fidelização, o algo a mais oferecido ao cliente" (op.cit.). 


\subsection{O Turismo na contemporaneidade: uma complexa combinação de elementos sociais}

Observa-se, a partir da leitura de estudiosos como Jaffar Jaffari (1994), John Urry (1996), Jost Krippendorf (2003), Marc Boyer (2003), Marustschka Moesch (2002, 2004) e Sergio Molina (2003), dentre outros, que é tempo de se repensar o Turismo em toda sua formação e complexidade, englobando fluxos, práticas, vivências, espaços e públicos. Sabese, porém, que, ao generalizar, pouco se contribui para o desenvolvimento de pesquisas e debates que possam desvelar fenômeno tão complexo quanto icônico, como é o Turismo.

[...] Quando as comunidades e os países descobriram o potencial econômico do turismo e se mobilizaram para melhor aproveitá-lo, este se converteu em um negócio, um comércio, uma indústria [...]. (JAFARI, 1994, p.7) $)^{5}$

Apesar de sua origem remontar a séculos, poucos fenômenos progrediram tão rapidamente. E seu crescimento vem despertando interesse, tanto como indústria quanto como fenômeno. Jafari (op.cit.) agrupa os estudos desenvolvidos e que sustentam tal observação em quatro plataformas de pensamento que, apesar de terem surgido em tempos distintos, coexistem na atualidade:

a) Defensora: el bien - cuja origem remonta às primeiras décadas do século $\mathrm{XX}$, com foco no viés econômico, e sustentando ser o turismo uma indústria que gera empregos e beneficia setores diversos;

b) de Advertencia: el mal - vozes audíveis na década de 1960 rechaçam a base anterior, argumentando sobre os efeitos negativos do turismo, tais como o de que os empregos gerados são temporários, com mão-de-obra desqualificada, e que o turismo destrói os recursos naturais;

c) de Adaptacion: el como - plataforma que desponta na década de 1980 como conciliadora, voltada para formas alternativas de turismo, como o de base comunitária e ecoturismo; e

d) Basada en el Conocimiento: el porqué - plataforma científica, embasada em construções teóricas, que estrutura os estudos de modo sistematizado e examina as flexões e inflexões sobre o fenômeno turístico.

\footnotetext{
5 “[...] Cuando las comunidades y los países descubrieron el potencial económico del turismo y aunaron esfuerzos para aprovecharlo, éste se convirtió en un negocio, un comercio, una indústria [...]." (JAFARI, 1994, p.7)
} 
Esse processo de formação do conhecimento em torno da prática e da teoria vem ajudando a estimular os estudos científicos voltados para o Turismo. E o principal beneficiado com esse desenvolvimento é a própria indústria turística (op.cit.).

Como ressalta Moesch (2004, p. 13), "uma epistemologia social do Turismo, crítica e emancipatória, poderá compreender como e por que as ideologias da cientificidade podem demarcar interesses diversos da sociedade". É, portanto, preciso desconstruir a percepção comum do que vem a ser Turismo, a fim de melhor compreendê-lo e interpretá-lo em sua dimensão e multidisciplinaridade e interdisciplinaridade. Entende-se que, com isso, poder-seá perceber melhor também seus correlatos e componentes, como é o caso da Hospitalidade neste estudo, de modo especial, a praticada pelo CCBB DF, por meio de um discurso proferido, o qual o solidifica como lugar de acolhimento e visitação turística na capital federal.

Neste momento de grandes transformações pelas quais passa o mundo contemporâneo, faz-se mister observar a relação entre o objeto (Turismo) e a forma de estudá-lo. $\mathrm{O}$ observador, sujeito investigador, sabe que toda teoria emana da prática, mas não se pode negar que esta pode ser reinventada por aquela. E esse sujeito está vinculado ao seu tempo, vai se inteirar de sua realidade e por esta será naturalmente transformado.

Há que se identificar e refletir as várias ambiguidades do campo. Afinal, só se faz ciência a partir de conceitos e de investigações. Há que se ultrapassar a competência técnica e operacional e o paradigma estratégico. [...] (SIQUEIRA, 2005, p. 83)

Siqueira alerta para a atenção do estudioso quanto à complexidade de seu objeto. Nesse sentido, a autora concorda com Geertz, que alerta para a função primeira do pesquisador: a de ter sempre o segundo olhar, porque o observador nunca será "um" ou "o" nativo - e mais, ele possui a interpretação racional dos códigos (GEERTZ, 1989, p. 24).

Por seu caráter interdisciplinar, a ciência do Turismo pode se beneficiar de inúmeras maneiras das mais diversas abordagens que recebe, bem como dos mais distintos campos de conhecimento com os quais se relaciona. A chamada Análise do Discurso é um deles. E é por essa metodologia que se pretende investigar o discurso de hospitalidade proferido pelo CCBB em seu site e página do Facebook. Como atesta Moesch (2004, p. 232), “[...] não será possível entender uma célula, a estrutura do cérebro, a família, uma cultura ou o Turismo se forem isolados de seus contextos. O relacionamento é tudo". 
O Turismo é uma combinação complexa de inter-relacionamentos entre produção e serviços. Em razão de não ser uma atividade produtiva agrícola ou industrial, normalmente é classificada no setor terciário ou de serviços. É muito mais que uma indústria de serviços, pois o fenômeno turístico é a composição de uma prática social com base cultural, com herança histórica, meio-ambiente diverso, cartografia natural, relações sociais de hospitalidade, troca de informações interculturais. $O$ somatório desta dinâmica sociocultural parte de um fenômeno recheado de objetividade/subjetividade, que venha a ser consumido por milhões de pessoas, enquanto síntese - o produto turístico, que está sendo tratado como um fenômeno totalizante, e não dialeticamente - uno/diverso, mas como produto final possível de total controle, suficiente em si mesmo. (MOESCH, 2004, p.15)

Nesta assertiva, a professora Moesch destaca os diversos fatores que tornam o Turismo um fenômeno complexo e fascinante. E, ao estabelecer estar ele associado a uma soma de elementos de base sociocultural, oferece as ferramentas para o estudioso encontrar sentido em sua análise, por meio do recorte do objeto. Como a deste estudo recai sobre a Hospitalidade, há de se lembrar de Derrida, para quem ela, a hospitalidade, é dada na acolhida, dentro da ideia do incondicional. É um serviço, mas também relacionamento que se rompe ou se fortalece. Quais são, então, as questões que norteiam o CCBB em termos de hospitalidade?

Percebe-se que o Centro se relaciona com seu público antes mesmo da chegada deste ao Setor de Clubes Sul, quando, ainda no âmbito do discurso inserido no universo virtual, convida o visitante a frequentá-lo, acolhendo-o como se ali estivesse pela primeira vez. O citadino parece querer conhecer as manifestações de sua cidade, como nos mostra o incipiente entendimento sobre o que vem a ser um turista cidadão, expressão introduzida na literatura do Turismo por Susana Gastal e Marutschka Martini Moesch no livro "Turismo, Políticas Públicas e Cidadania”. Para a professora Moesch,

O turista cidadão é aquele morador da localidade que vivencia práticas sociais, no seu tempo rotineiro, dentro de sua cidade, de forma não rotineira, onde é provado em relação à cidade. Turista cidadão é aquele que resgata a cultura da sua cidade, fazendo uso do estranhamento da mesma. Este estranhamento inicia no momento em que o indivíduo descobre, no espaço cotidiano, outras culturas, outras formas étnicas e outras oportunidades de lazer e entretenimento. Quando se encontra na situação de turista cidadão, este sujeito aprende a utilizar os espaços ambientais, culturais, históricos, comerciais e de entretenimento com uma percepção diferenciada do seu cotidiano. (GASTAL e MOESCH, 2007, p. 65)

Essa hodierna abordagem passa pela necessidade de o homem contemporâneo voltar seu olhar com acuidade para onde vive, posto que as cidades, para os residentes, não desempenham a função somente de morada, mas desafiam governantes e estudiosos por sua 
complexa estrutura. Dotadas de bens simbólicos, estão povoadas por cidadãos aptos e ávidos por exercer sua cidadania, o que inclui sua função de hospedeiro, anfitrião em seu espaço cotidiano.

Mas o que significa ser cidadão, ou antes, o que o complexo fenômeno da cidadania tem a ver com Turismo? "Cidadania não é uma definição estanque, mas um conceito histórico, o que significa que seu sentido varia no tempo e no espaço", afirmam Pinsky et al (2008, p. 9). Ao enfatizar esse caráter dinâmico, o autor indica que houve um início e com ele um percurso percorrido para a composição da cidadania.

Para outro autor, Alain Montandon, cidadania tem a ver com a noção e as condições de acolhida do outro, intervindo diretamente sobre a hospitalidade do espaço dentro de dispositivos e regulamentos públicos.

[...] Um dos traços constitutivos do direito de cidadania é a variedade de suas formas, quando se considera simultaneamente sua natureza e as razões de sua atribuição. Os direitos de residir, de circular, de ser cidadão, de ter a nacionalidade, oscilam entre o direito de qualquer comunidade de definir o pertencimento e o argumento das "leis não escritas" da humanidade. O próprio Kant, depois de ter sublinhado que a hospitalidade do Estado deve ser pensada do ponto de vista jurídico e não filantrópico, e afirmado que esse direito funda a obrigação de conceder um direito de visita, mas não de residência, dá conta desse direito através de outro, o da posse da terra por todos os homens. A reflexão sobre a outorga ou a recusa do direito de cidadania, se quiser ser um pensamento da hospitalidade de Estado para além do direito de visita, deve ser acompanhada por uma interrogação sobre as modalidades de acolhida oferecidas aos recém-chegados. (MONTANDON, 2011b, p.995)

Um breve deslocamento pela história contribuirá para a identificação da origem da palavra. A trajetória avant la lettre, como narram Pinsky et al (2008, p. 15-27), dá conta de "profetas sociais" que defendiam cuidados e proteção aos menos favorecidos. No entanto, o termo "cidadania" vem do latim "civitas", que quer dizer "cidade". Utilizado na antiga Roma, carregava consigo a expressão dos direitos que uma pessoa poderia exercer. De acordo com o jurista Dalmo de Abreu Dallari,

A cidadania expressa um conjunto de direitos que dá à pessoa a possibilidade de participar ativamente da vida e do governo de seu povo. Quem não tem cidadania está marginalizado ou excluído da vida social e da tomada de decisões, ficando numa posição de inferioridade dentro do grupo social. Por extensão, a cidadania pode designar o conjunto das pessoas que gozam daqueles direitos. [...] (DALLARI, 2004, p.22) 
Tal concepção remete às revoluções liberais, burguesas, do século XVIII, de modo especial as inglesas (1640 a 1688), que formaram as bases para a independência dos Estados Unidos e sua Carta de Direitos (1776), e a Revolução Francesa (1789). Pertence a cada uma delas o crédito de ser o alicerce da cidadania como esta é concebida em pleno limiar do século XXI.

\begin{abstract}
A cidadania instaura-se a partir dos processos de lutas que culminaram na Independência dos Estados Unidos da América do Norte e na Revolução Francesa. Esses dois eventos romperam o princípio de legitimidade que vigia até então, baseado nos deveres dos súditos e passaram a estruturá-lo a partir dos direitos do cidadão. Desse momento em diante todos os tipos de luta foram travados para que se ampliasse o conceito e a prática de cidadania e o mundo ocidental o estendesse para as mulheres, crianças, minorias nacionais, étnicas, sexuais, etárias. Nesse sentido pode-se afirmar que, na sua acepção mais ampla, cidadania é a expressão concreta do exercício da democracia. (PINSKY e PINSKY, 2008, p. 10)
\end{abstract}

De acordo com José Murilo de Carvalho, a cidadania plena é um ideal e, portanto, sem garantia de ser atingida. Afinal, ela deve combinar liberdade e igualdade para todos, sem qualquer distinção de raça, cor, credo etc. "Tornou-se costume desdobrar a cidadania em direitos civis, políticos e sociais. O cidadão pleno seria aquele que fosse titular dos três direitos. [...]" (CARVALHO, 2012, p. 9).

Qual seria, então, a importância de o indivíduo exercer esse direito como turista dentro de sua própria cidade? Para as precursoras Gastal e Moesch, deve-se primeiramente, considerar que turismo está relacionado a deslocamento, a vivência de experiências de estranhamento em relação ao desconhecido, incluindo o lugar onde se vive:

Para Moesch, a experiência do turista cidadão, carregada de subjetividade, se expressa, porém, objetivamente nas vivências ocorridas durante o tempo de lazer, no consumo de práticas de entretenimento, cultura e meio ambiente. Esse processo ocorreria por meio do estranhamento da própria cidade, especialmente na percepção estética da paisagem urbana pelo habitante. (GASTAL e MOESCH, 2007, p. 66)

E o cidadão de Brasília apropria-se do espaço do CCBB DF ao visitar as exposições, participar das atividades promovidas e até articulando movimentos próprios - como o piquenique na área externa - sendo um turista na cidade em que reside, ao mesmo tempo hóspede e anfitrião nesse ambiente. Em seu processo de chamamento, por meio do site e das redes sociais, o Centro atua como aglutinador, estimulando a população a incorporar, em seu cotidiano, o hábito de visitar o CCBB com o olhar, não de um turista qualquer, sem vínculo 
com o lugar, mas de um visitante cuja percepção ultrapassa os sentidos daquele que recebe. Esse turista é especial, posto ser partícipe, ao apropriar-se do espaço, como um legítimo anfitrião.

Mas há inúmeros riscos embutidos nessa cena. Para o anfitrião, os riscos são os da intrusão, do parasitismo, quando não das simples inconveniências dos seus hóspedes. Para estes, por outro lado, os riscos são o de ter pela frente um anfitrião inospitaleiro ou mesmo hostil, desconhecedor das leis da hospitalidade ou que abusa do direito sobre o espaço, até mesmo sufocando o hóspede de gentilezas ou agredindo-o seja física, seja psicologicamente [...]. (CAMARGO, 2011, p.17)

O número de visitantes conquistados, que a cada dia se interessam mais e mais pelo Centro, parece comprovar que o CCBB acolhe sem sufocar. Pode-se considerar que essa acolhida quebrou paradigmas, já que houve tempo que o Centro Cultural era identificado, pelo visitante, como um espaço destinado ao turista elitista.

Uma questão que salta aos olhos quando se depara com os elogios e opinião dos visitantes e as reportagens e colunas dos jornais sobre os espaços dos CCBB é a intermitente referência à sensação européia de seus ambientes, ao padrão de limpeza e qualidade da programação típicas de Primeiro Mundo, impressões que demarcam as fronteiras espaciais de um mundo recluso de civilidade e remanso em meio à realidade bruta e exasperada dos centros metropolitanos brasileiros [...]. (VIEIRA, 2006, p.183)

Ainda que tal ótica possa persistir, apesar do número crescente de público visitante - o que denota o acesso de diferentes classes sociais - adotá-la seria apartar-se da realidade, além de preconceituoso. É como se de imediato se preconcebesse que públicos não habituados ao universo artístico não são aceitos ou contemplados em um centro que se pretende cultural em seu sentido mais amplo.

Lei paradoxal ou perversiva: ela toca esse constante conluio entre a hospitalidade tradicional, a hospitalidade no sentido corrente, e o poder. Esse conluio é também o poder em sua finitude, a saber, a necessidade, pelo hospedeiro, de escolher, de eleger, de filtrar, de selecionar seus convidados, seus visitantes ou seus hóspedes, aqueles a quem ele decide oferecer asilo, direito de visita ou hospitalidade. Não há hospitalidade, no sentido clássico, sem soberania de si para consigo, mas, como também não há hospitalidade sem finitude, a soberania só pode ser exercida filtrando-se, escolhendo-se, portanto excluindo e praticando-se violência. [...] (DERRIDA, 2003, p.49)

A pesquisa procura identificar se o CCBB DF é esse anfitrião soberano na linguagem que utiliza para fazer-se conhecer. Em outras palavras, o Centro constitui-se lugar de 
acolhimento do turista por meio do discurso veiculado em seu próprio site e em sua página no Facebook? Lugar de visitação de públicos diferenciados e diversificados, posto que oportunidades para visitação são oferecidas. Isso, desde o convite feito virtualmente, passando pelo deslocamento, com os ônibus gratuitos que percorrem locais de acesso fácil - região da rodoviária, setor hoteleiro e universidade federal, dentre outros - até a acessibilidade à programação propriamente dita, com eventos com entrada franca ou a preços populares. Ao chegar ao local, o visitante ainda encontra orientadores do Programa Educativo, os quais atendem também alunos de escolas do Distrito Federal - aquelas de instituições públicas chegam ao CCBB por meio de transporte disponibilizado pelo próprio Centro. E, assim, a hospitalidade do anfitrião completa seu ciclo, iniciado pelo convite. 


\section{CAPÍTULO 2 - NA ORIGEM - UM ESPELHO DAS METRÓPOLES}

“Quando a ignorância começa a ousar, é porque tem uma bússola consigo.”

Victor Hugo

O Centro Cultural Banco do Brasil (CCBB) é uma instituição cujo principal mecenas é um ente financeiro de economia mista denominado Banco do Brasil. Existem, no país, quatro CCBBs que, ao longo de 25 anos de história, "receberam mais de 74 milhões de visitantes", ao realizar "mais de 3.600 projetos, consolidando-se como uns dos principais centros culturais no cenário cultural brasileiro e internacional.” (BANCO DO BRASIL, 2015a, p.1).

A definição e a execução da estratégia de Marketing Cultural no Banco do Brasil é competência da Diretoria de Marketing e Comunicação, que realiza e ativa projetos patrocinados (em sua maioria com incentivo da Lei Rouanet) nos Centros Culturais Banco do Brasil, que constituem unidades de apoio da Diretoria. A sustentabilidade do "negócio CCBB" busca um novo modelo de financiamento da programação e das despesas administrativas, e não somente da programação como é o modelo atual. (op.cit.)

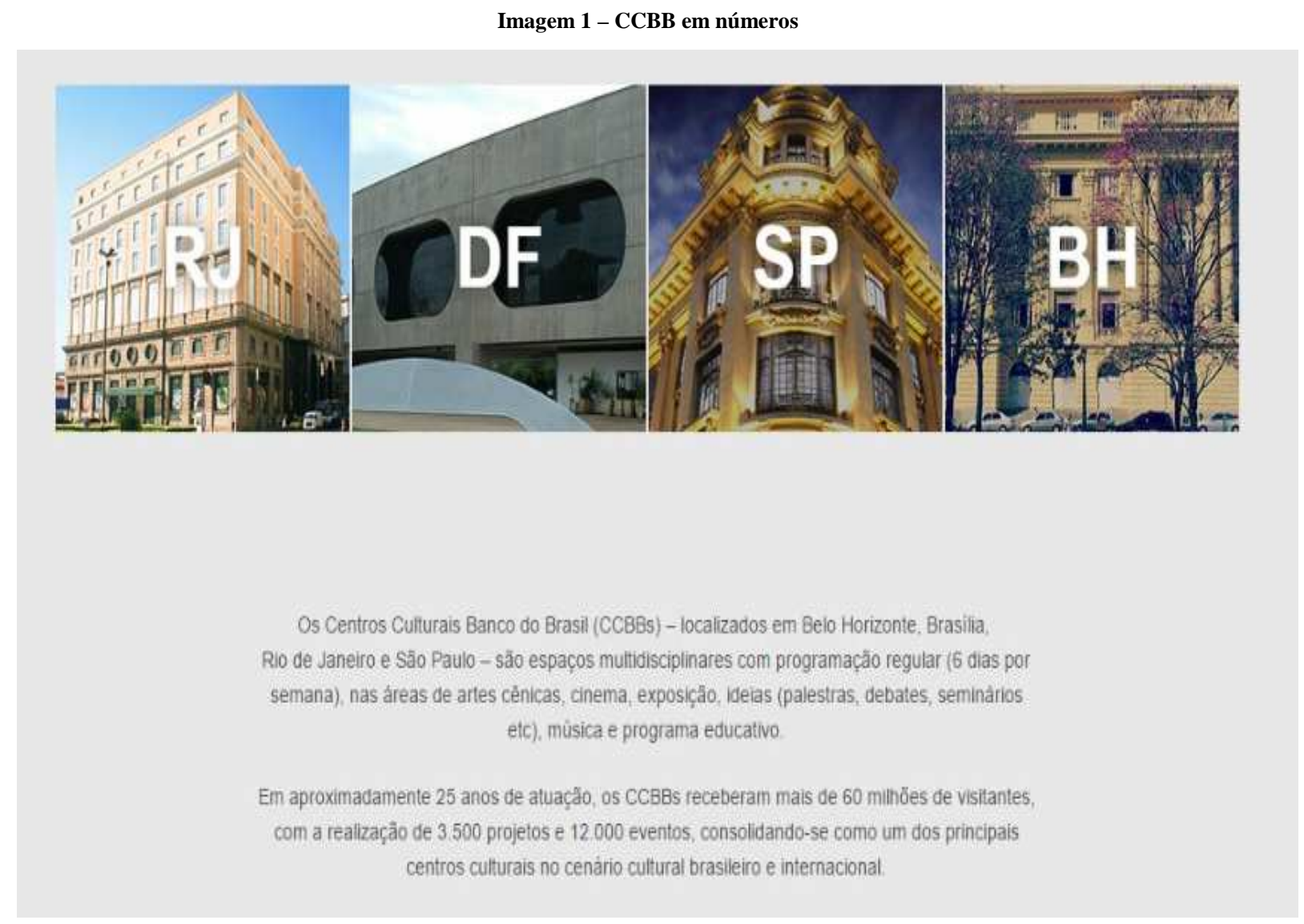

Fonte: http://culturabancodobrasil.com.br/portal/ (Acessado em 14out2014, às 23h20) 
Os quatro CCBBs recebem o nome das respectivas cidades nas quais estão sediados: CCBB Rio de Janeiro, CCBB Brasília, CCBB São Paulo e CCBB Belo Horizonte. Informações sobre cada um deles, bem como sua programação mensal, podem ser encontradas no site exclusivo mantido pela instituição financeira que os suporta. Logo na primeira página, imagens da fachada de cada um deles, acompanhadas de um texto genérico, único, demonstra a unicidade de discurso.

Em sua estrutura, cada Centro Cultural Banco do Brasil é constituído por um gerente Geral, um gerente de Programação e outro Administrativo/Comunicação. A exceção fica com a unidade carioca, posto contar com um gerente de Patrimônio, em função do Museu do Banco do Brasil, existente somente naquele espaço. Cada gerente responde, portanto, por uma respectiva área, e conta com funcionários de carreira, escolhidos por meio de seleção interna para compor o corpo funcional relativo aos assessoramentos.

As áreas Administrativa e de Comunicação foram unificadas em meados de 2013, quando os CCBBs passaram por uma reestruturação, com o objetivo de manter uma estrutura enxuta e ainda inaugurar seu quarto espaço, o CCBB BH. Na Diretoria de Marketing e Comunicação (Dimac), que à época geria os centros, foi criada a Divisão de Marketing Cultural, com a tarefa de coordenar os quatro espaços, o que significa a contratação de projetos de grande porte e alçadas maiores, além de organizar questões gerais relativas ao quarteto cultural. Cada Centro, porém, manteve seu núcleo de Programação e Administrativo/Comunicação, com a função de gerir e organizar o espaço, com menos profissionais que em anos anteriores.

Em meados de 2015, a reestruturação alcançou diversas diretorias, incluindo a Dimac, que, em parte, fundiu-se com a Diretoria Estratégia Organizacional, formando a Diretoria de Estratégia da Marca (Direm). Por sua importância estratégica, o marketing digital tornou-se Diretoria de Negócios Digitais (Dined) e a divisão de relacionamento com a imprensa, Unidade Assessoria de Imprensa. As demais ações de marketing esportivo, cultural, institucional, publicidade e propaganda ficaram com a Direm. Logo, também os CCBBs que, por não serem unidades independentes, obedecem a diretrizes traçadas por esta Diretoria, que responde diretamente ao presidente do Banco, conforme estrutura a seguir: 
Imagem 2 - Organograma BB

\section{Banco do Brasil}

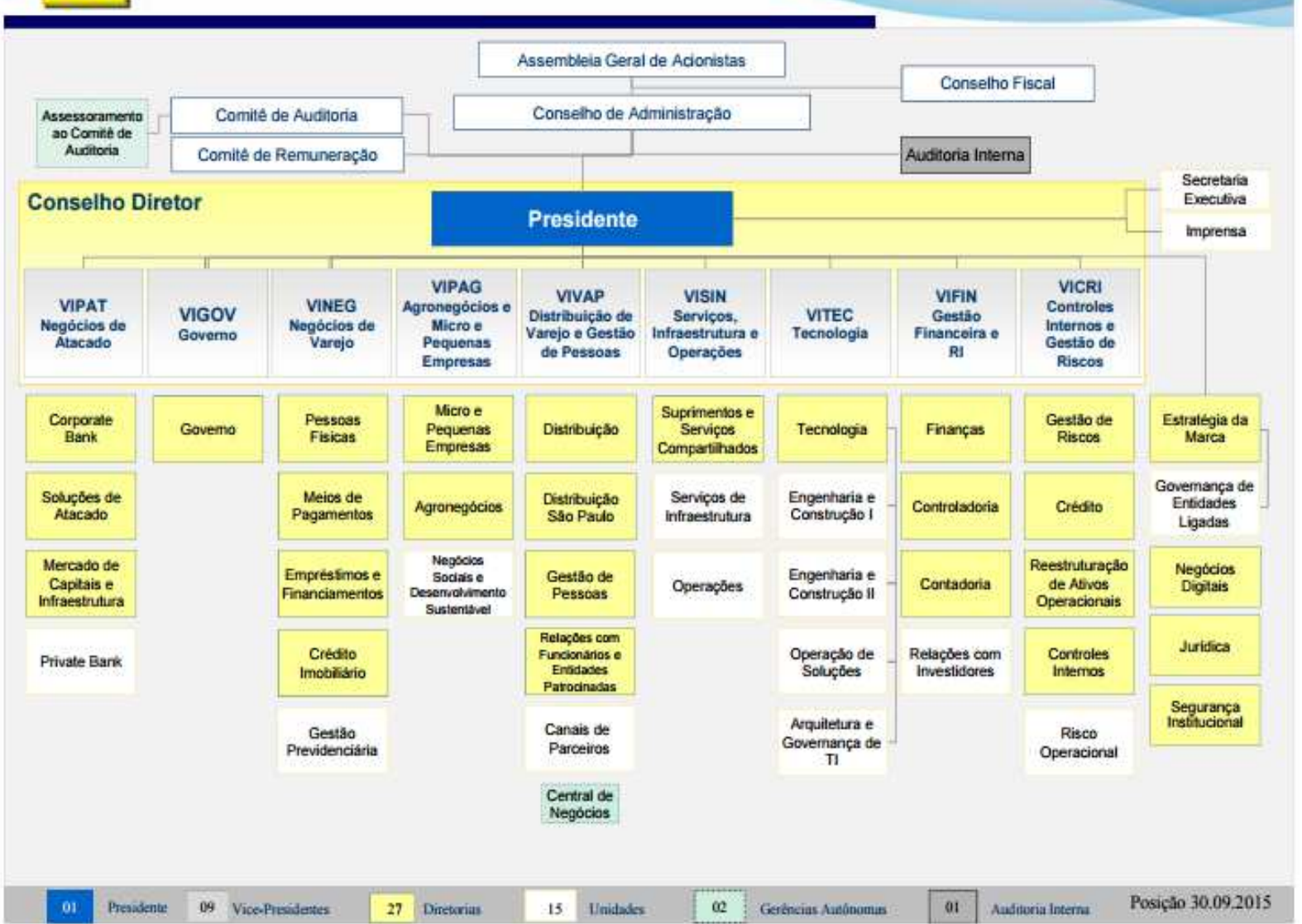

Fonte: http://www.bb.com.br/docs/pub/siteEsp/ri/pt/dce/dwn/3T15EstSR.pdf (Acessado em 12dez2015, às 19h54)

\subsection{Um centro cultural na capital federal}

A escolha dos edifícios que abrigam os quatro centros foi sempre pautada na revitalização da região, na acessibilidade e na valorização de importantes centros históricos. O CCBB Brasília é o único que foge à regra, ao situar-se fora da área central urbana, no Setor de Clubes Sul, Trecho 2, Edifício Tancredo Neves. O objetivo de sua constituição, porém, passava pela integração.

O parecer [...] de criação do CCBB Brasília, datado de 9 de fevereiro de 2000, [...] expressava uma conotação urbanística, ao assinalar o potencial do prédio escolhido para acolher o projeto, o Edifício Tancredo Neves, complexo projetado por Oscar Niemeyer para sediar a área de gestão de pessoal do Banco do Brasil, construído ao final da década de 1980, por se localizar "em área que atualmente está sendo reurbanizada - Projeto Orla o que facilitará o acesso por transporte público". (VIEIRA, 2006, p.211) 
O projeto do complexo foi realizado pelo arquiteto Oscar Niemeyer com o intuito de abrigar o Centro de Formação do Banco do Brasil (Cefor). A proposta original era, assim, voltada, exclusivamente, para o desenvolvimento da educação bancária dos funcionários da instituição financeira. O acesso seria facilitado com a implantação do Projeto Orla (Plano de Ordenamento e Estruturação Turística de Brasília), concebido originalmente para revitalizar o Lago Paranoá, o qual deveria ser

[...] composto por 11 pólos, planejados para funcionarem tanto no período diurno como noturno e um Calçadão, designado de Alameda que os interligam. Estão previstas várias utilizações para estes pólos, que vão desde a hospedagem às culturais, passando pelo comércio e lazer, com oferta de ambientes atrativos e de meios agradáveis de estada, tudo para aumentar o tempo de permanência do turista na cidade. (GOVERNO DO DISTRITO FEDERAL, 1995, p.11)

No entanto, o Projeto Orla jamais foi implantado. O Cefor, por outro lado, foi inaugurado em 1993. Todavia, as obras previstas no traçado original de Niemeyer não foram concluídas, como demonstra a maquete (ver Imagem 3 - Anexos) que fica à entrada da administração do CCBB Brasília, no segundo andar do edifício.

No final dos anos 1990, parte do prédio foi reformada para receber as instalações do CCBB Brasília. O Banco do Brasil vinha de uma experiência bem-sucedida no Rio de Janeiro. Desde que fora inaugurado, em 1989, o CCBB RJ tornou-se referência no cenário nacional pela qualidade, diversidade e regularidade da programação. O modelo levou o referido Centro a desenvolver um guia para criação e utilização de espaços culturais para todo e qualquer empreendedor com recursos para tal. O manual, denominado "Guia para formação e utilização de espaços culturais" (CENTRO CULTURAL BANCO DO BRASIL, 1997), traz, com certo detalhamento, indicações de como uma instituição deve instalar e gerir um ambiente cultural, com informações desde a escolha do local, passando por dicas de revestimentos de paredes, iluminação, organização do espaço, realização de eventos e até formação de pequenas bibliotecas. Não se pode afirmar peremptoriamente que foi um dos norteadores para os projetos de CCBB que se seguiram. Por outro lado, uma instituição com grande apreço por suas boas práticas e realizações não poderia desperdiçar as próprias experiências de sucesso.

Em 12 de outubro de 2000, no mesmo dia em que o Banco do Brasil completava 192 anos, nascia, na capital federal, o segundo Centro Cultural do Banco do Brasil do País - o terceiro foi implantado em 2001, na capital São Paulo (SP), e o último em 2013, em Belo Horizonte (MG). Com assinatura de Alda Rabelo Cunha, o projeto paisagístico do Centro 
brasiliense ressaltava o conjunto arquitetônico de concreto, projetado por Oscar Niemeyer, composto por dois andares, assentado sobre pilotis e dividido em módulos.

Era, porém, preciso adaptar o espaço para receber exposições, apresentações de artes cênicas e musicais. Para transformar um prédio projetado para ser centro de treinamento interno em espaço de fomento da arte, foram cinco meses de obras, com investimento de “R\$1,4 milhão (R\$600 mil a menos que o planejado)" (MACIEL, 2000, p.20).

Reportagem do jornal Correio Braziliense da época, intitulada "Por dentro do Centro", registra a dimensão da estrutura que surgia no planalto central. No texto, o jornalista Klecius Henrique oferece dicas de como se chegar ao local, o que fazer (programação), e ainda exibe ilustrações para melhor identificar os espaços disponíveis ao público que, pela primeira vez, entraria em contato com o CCBB Brasília.

O caminho pode não ser dos mais fáceis, mas vale a pena destrinchá-lo para chegar ao Centro Cultural Banco do Brasil - Brasília. Localizado no trecho 2 do Setor de Clubes Esportivos Sul, onde funciona o Centro de Treinamento do Banco do Brasil, prédio projetado por Oscar Niemeyer, o mais novo espaço cultural da cidade abre as portas hoje para o público. Em cartaz, as exposições Amílcar de Castro e Arte Popular - Brasil + 500 - módulo da Mostra do Redescobrimento - e, a partir de amanhã, a peça $O$ Avarento, dirigida por Amir Haddad. (HENRIQUE, 2000, p.1)

Nos três parágrafos seguintes de seu retrato sobre aquela novidade, o periodista demonstra que a preocupação com a distância e com a mobilidade urbana, ou seja, o acesso ao Centro, já se faziam presença desde o início. Destaque para a solicitação do CCBB ao Departamento Metropolitano de Transportes Urbanos (DMTU) por melhores serviços para a região, pois o Setor de Clubes Sul estaria "localizado em área malservida de ônibus". O repórter ainda reforça: "Para quem tem carro, a história é diferente. O estacionamento, com 500 vagas, é grátis e tem segurança garantida pelo CCBB, que fará controle de entrada e saída dos carros." (op.cit.)

Especula-se que essa característica tenha contribuído para o viés "elitista" dado ao Centro. Apesar de amplo e com uma intensa programação, o CCBB de Brasília chegava tímido, ocupando, em princípio, parte do prédio principal do Edifício Tancredo Neves: duas estruturas cilíndricas e um vão central arejado e livre de paredes.

[...] Importa registrar que o projeto do CCBB Brasília era bem mais acanhado que o de São Paulo, porquanto originalmente se circunscrevia a duas galerias, praticamente. O sucesso do empreendimento, no entanto, levou à expansão que o fez absorver o anterior auditório da Diretoria de 
Gestão de Pessoas, para instalação do teatro, e obter mais salas para exposições. (VIEIRA, 2006, p.211)

O Centro abria as portas ao público trazendo "extremos da arte brasileira" (MACIEL, 2000, p.20). Para ela, "o módulo Arte Popular e as esculturas de Amílcar de Castro colocam lado a lado o naïf e o neoconcretismo, o singelo e o sofisticado" (op.cit.). Havia, ainda, no teatro, um clássico da dramaturgia cômica, $O$ Avarento, de Molière, sob a direção de Amir Haddad, um dos ícones da cena dramática brasileira. Na semana seguinte, os brasilienses poderiam acompanhar a série musical Contraponto Cerrado - O melhor da música instrumental brasileira e as Rodas de leitura, tendo como primeiro convidado o poeta Ferreira Gullar. Assim, o Centro se apresentava à cidade com intensa programação de artes plásticas, artes cênicas, música, ideias e programa educativo - uma de suas iniciativas mais bemsucedidas de arte-educação. Faltaria apenas a sala de cinema, inaugurada em 2003, com a mostra Brasília 24 Quadros, com exibição de filmes realizados na cidade de 1962 até 2002.

Desde o início, portanto, a brasilidade dava o tom daquele espaço que, anos mais tarde teria destaque como o segundo museu/centro cultural ${ }^{6}$ mais visitado do país e o $45^{\circ}$ no mundo, com 1.155.036 visitantes (THE ART NEWSPAPER, 2012, p.37) ${ }^{7}$. E essa identificação, esse apreço pelo nacional, provinha de um projeto de cidadania, como destaca artigo de Paolo Enrico Maria Zaghen, presidente do Banco do Brasil à época da inauguração:

A preservação e a divulgação da cultura brasileira são formas de consolidar o posicionamento do Banco do Brasil, empresa cuja história é de profunda inserção no cotidiano de milhares de comunidades do país. (ZAGHEN, 2000)

Por sua capilaridade, não interessava ao Banco ter planejado um Centro sem visitantes. Afinal, como afirmou o dirigente, a instituição é parte da sociedade brasileira.

Os resultados positivos não demoraram e, dois anos após sua inauguração, o CCBB Brasília recebia a Comenda da Ordem do Mérito Cultural do Distrito Federal pelos relevantes serviços prestados à cultura brasileira. Entre outubro de 2000 e setembro de 2002, o Centro havia recebido mais de 300 mil espectadores, para os seus 713 eventos realizados. Só o Programa Educativo havia sido responsável por recepcionar cerca de 89 mil estudantes de

\footnotetext{
${ }^{6}$ A publicação inglesa não distingue museu de centro cultural, considerando, no levantamento, espaços exibidores existentes ao redor do globo.

${ }^{7}$ Em 2011, destaca a publicação, o primeiro lugar no Brasil ficou com o CCBB Rio de Janeiro, com total de 2.288.117 visitantes e o CCBB São Paulo em terceiro lugar, com 1.058.114. Em relação ao posicionamento no mundo, a unidade carioca ocupou o $17^{\circ}$ posto enquanto a paulista a $50^{\mathrm{a}}$ posição. $\mathrm{O}$ museu mais visitado no mundo foi o Louvre, em Paris (França) com 8.880.000 pessoas, seguido pelo Metropolitan Museum of Art, de Nova York (EUA), com 6.004.254, e pelo British Museum, de Londres (Grã-Bretanha), com 5.848.534 visitantes.
} 
escolas públicas e privadas (CULTURA E MERCADO, 2002). A acolhida caracterizou-se, desde sempre, como um aspecto peculiar para o Centro.

Com o sucesso dos números, eram inevitáveis os planos de crescimento. E, ao longo dos anos, o espaço foi ganhando novas estruturas e projeções: uma área localizada em um dos módulos do edifício, onde atualmente trabalham os funcionários que coordenam as atividades, outras duas galerias, outro teatro, uma sala de cinema, pavilhões de vidro (Vide Imagens 3, 4, 6, 7, 8, 12 nos Anexos). No ambiente que convida à convivência, a gastronomia se faz presente por meio de um bistrô e uma cafeteria, enquanto a livraria oferece cardápio para ocupar as mentes ${ }^{8}$. Na área externa, uma exposição permanente e interativa, "Casulo", composta de obras de Darlan Rosa que animam o dia-a-dia das crianças (vide Imagem 4 Anexos), uma instalação, “Améfrica” (vide imagem 5 - Anexos), de Denise Milan, além de bancos com espaço para leitura e vista para o lago.

Prédios monumentais de Niemeyer com grandes jardins há vários em Brasília. No caso deste, um dos ocupantes mudou a história do monumento. É o Edifício Tancredo Neves. Foi construído para ser o Centro de Treinamento do Banco do Brasil e ainda é! Teve Lula despachando e tomando decisões importantes para o país durante quase um ano e meio em uma ponta do prédio, enquanto o então presidente esperava a reforma do Palácio do Planalto. Mas é o espaço que ocupa apenas a outra ponta do edifício que mexe com a cidade. Virou referência cultural e afetiva com suas salas de exposição, teatro, cinema e espetáculos ao ar livre e que fazem parecer que é dono do pedaço, e às vezes é. (SOUZA, 2011)

Brasília, a cidade, está intrinsecamente ligada ao seu arquiteto, Oscar Niemeyer. As anotações de Souza remetem a essa quase onipresença e conta, em poucas palavras, as transformações sofridas pelo prédio batizado com o nome de Tancredo Neves, o primeiro presidente civil eleito (por eleições indiretas) após 20 anos de ditadura militar. É preciso atualizar, porém, duas referências dadas acima. A primeira, relativa à múltipla função do CCBB. Entre os anos de 2009 e 2010, parte do edifício abrigou o gabinete presidencial de Luís Inácio Lula da Silva, tendo em vista a primeira grande restauração do Palácio do Planalto, desde que fora inaugurado, em 21 de abril de 1960. O Blog do Planalto, produzido pela Secretaria de Comunicação da Presidência da República, à época, publicou:

Com sua extensa programação cultural, o CCBB é um vizinho tentador para quem tem que trabalhar ao longo da semana. São muitas as atividades todos os dias, para todos os gostos, de exposições de artes plásticas a peças de

\footnotetext{
${ }^{8}$ Os espaços gastronômicos e a livraria não são geridos pelo CCBB, mas por empresas privadas, cuja concessão é conseguida via concorrência pública: http://www.bb.com.br/editaislicitacoes.
} 
teatro, festivais de cinema e rodas de leitura. Não é raro ver muitos dos funcionários da Presidência voltando ao 'local de trabalho' nos fins de semana, justamente para aproveitar esse variado leque de opções. E o que é melhor: as atividades oferecidas pelo CCBB são baratas, em alguns casos até gratuitas. Para saber mais sobre a programação, visite o site oficial e acompanhe as atualizacões do CCBB de Brasília no Twitter. (GOVERNO FEDERAL, 2009)

O tom era de que havia sido uma alternativa que agradara aos servidores, trocar o Palácio do Planalto pelo espaço "amplo, fresco" e com "vista para um dos pontos turísticos mais bonitos da capital federal, a ponte JK" (op.cit.). O Blog ainda oferecia ao leitor links para o site e para o Twitter do centro cultural, o que pode levar a uma dupla interpretação: a de demonstração de que o prazer estava ao lado e a de retribuição da hospitalidade. Não por menos o título da matéria prenunciava "CCBB, um anfitrião cultural”.

Observa-se, com isso, o quanto a hospitalidade do CCBB Brasília é um elemento reconhecido e reforçado, seja na imprensa, seja nas manifestações dos visitantes em geral, seja nas publicações próprias nas mídias e redes sociais.

Com amplo estacionamento, opções de gastronomia e vista privilegiada, parte do CCBB abriga secretarias da Presidência da República com status de ministérios. Antes, porém, de receber o staff presidencial, em função das reformas de um dos principais prédios da Praça dos Três Poderes, entre novembro de 2002 e janeiro de 2003, salas abrigaram o chamado governo de transição, propiciado por um arranjo político entre a administração de Fernando Henrique Cardoso e a aliança vencedora das eleições de 2002 (PT-PL). O fato se repetiu na passagem do segundo governo Lula para o primeiro mandato da presidenta Dilma Roussef, entre novembro de 2010 e janeiro de 2011.

A outra atualização ao texto de Souza (2011) refere-se à destinação do prédio. Entre meados de 2013 e início de 2015, todo o centro de treinamento foi transferido para um novo imóvel, na zona central de Brasília. O espaço desocupado em todo o primeiro andar do Edifício Tancredo Neves entrou em obras em outubro de 2013 para abrigar as instalações do futuro "Museu Banco do Brasil - História, Cultura e Cidadania”.

A base conceitual do projeto integra memória, preservação do patrimônio, e oferta de novas dinâmicas interativas que caracterizam os espaços expositivos modernos, com participação cada vez maior do público e atendimento qualificado aos visitantes. Já as etapas físicas de expansão contemplarão, no futuro, entrega de área completa de vivências culturais, de lazer e de entretenimento. (BANCO DO BRASIL, 2013) 
Tem-se, assim, o Edifício Tancredo Neves, idealizado para abrigar apenas uma parcela dos funcionários da instituição financeira, hospedando, em suas instalações, um espaço para apresentações artísticas, o qual se tornou "referência cultural e afetiva" (SOUZA, 2011) para os cidadãos brasilienses, pela programação que oferece aos seus visitantes. O sisudo prédio de concreto, quem diria, passava a ser visto, por quem a ele se achegava, como um generoso anfitrião.

\begin{abstract}
A hospitalidade desapropria os limites da propriedade. A instauração da propriedade pode decerto ser pensada como condição da hospitalidade: só podemos oferecer aquilo que nos pertence. Mas o anfitrião sacrifica seu bem para seu convidado; ele se desfaz de sua propriedade para que o convidado se torne seu proprietário [...]. (MONTANDON, 2011a, p.35)
\end{abstract}

O sacrifício do hospedeiro, primeiramente, custa-lhe seu próprio nome. Poucos referem-se ao local pelo seu nome oficial, Edifício Tancredo Neves. Todos os que para ali se dirigem, tanto os que frequentam os espaços culturais, o bistrô e a livraria, quanto os que ocupam os gabinetes das secretarias da Presidência da República, vão ao CCBB, ao hóspede que tomou as chaves da casa e apropriou-se do lugar de maneira cativante para todos os que o frequentam.

Crianças comportadas estão sempre presentes nos programas educativos. E nos fins de semana correm soltas e brincam em todos os espaços. Os convites para vernissages e estreias de peças teatrais são disputados e invejados, causam sempre um frisson, a cidade fica ansiosa para ver trabalhos inéditos de grandes artistas nacionais, internacionais e locais, que são também referência nacional em trabalhos que dialogam com a capital. A frequência é uma boa mistura - bancários (donos da casa), artistas, penetras, diplomatas, poucos políticos, executivos e estudantes, que ajudam a formar uma nova tribo de gente colorida e irreverente, "um povo CCBB", como a cidade já apelidou! (SOUZA, 2011)

O mundo lúdico e onírico descrito acima apresenta uma impressão sobre o perfil do visitante - "um povo CCBB": pessoas "descoladas" e interessadas em novidades. Estranhamente, professores estão ausentes da lista do artigo da fotógrafa, assim como jornalistas, dois profissionais intimamente relacionados ao espaço. Desperta atenção a descrição das "crianças comportadas" que nos finais de semana se libertam no mesmo ambiente. Contudo, não se pode afirmar que as mesmas "crianças comportadas" que frequentam o Programa Educativo com seus colegas e mestres sejam as mesmas que vão ao espaço nos finais de semana, provavelmente acompanhadas de familiares. 
[...] Convém que os hóspedes se sintam em grande liberdade, que se sintam em casa [...], que sejam acolhidos numa casa limpa, que as camas oferecidas sejam as melhores possíveis [...]. (MONTANDON, 2011a, p.33).

Nessa condição, atua para que se cumpram as leis da hospitalidade. O perfil do público visitante do $\mathrm{CCBB}$, como se observa, demonstra ser uma vasta linha de pesquisa e pode ser motivo de outros estudos. Neste trabalho, o foco é o CCBB como anfitrião e como ele atua neste campo, por meio dos textos que produz e divulga em seu próprio website e em sua página no Facebook.

"A história atribui funções diferentes ao mesmo lugar." (SANTOS, 2008, p. 59). O centro cultural brasiliense vem confirmando a premissa de Milton Santos, à medida que, nascido de uma adaptação de espaços, segue seu curso, sendo reordenado e acrescendo às galerias e teatro iniciais, sala de cinema, pavilhões de vidro e, mais recentemente, um andar integralmente destinado a funcionar como um museu. Para o geógrafo, a "produção do espaço é resultado da ação dos homens agindo sobre o próprio espaço, através dos objetos, naturais e artificiais". (op.cit., p.70). No CCBB, a intervenção humana visa ao prazer, ao deleite e, com ele, a aceitação do visitante.

A paisagem não se cria de uma só vez, mas por acréscimos, substituições; a lógica pela qual se fez um objeto no passado era a lógica da produção daquele momento. Uma paisagem é uma escrita sobre a outra, é um conjunto de objetos que têm idades diferentes, é uma herança de muitos diferentes momentos. (op.cit., p. 73)

Como se verá mais adiante, a paisagem obedece à lógica do contexto e, no CCBB, ela reflete tanto na acolhida do turista quanto na programação que oferece aos visitantes. Um exemplo dessa apropriação da paisagem são os curtas-metragens produzidos a convite do próprio Centro.

Ao longo de todo o ano de 2011, pairava a sombra da profecia de Nostradamus de que o mundo iria acabar em 2012 - Hollywood se apressou a fazer um longa-metragem de ação que atingia até o Cristo Redentor, no Rio de Janeiro ${ }^{9}$. Nos CCBBs, as redes sociais ainda não contavam com tantos seguidores. Uma ideia reuniu os três centros existentes à época (CCBB DF, CCBB RJ e CCBB SP) na divulgação e efetivação das respectivas páginas. Trata-se da promoção "Curta 2012 no CCBB”, um concurso de abrangência nacional, para maiores de 18 (dezoito) anos, inclusive "funcionários, contratados, estagiários e terceirizados do Conglomerado Banco do Brasil, residentes e domiciliados no território nacional" (BANCO

\footnotetext{
${ }^{9}$ Intitulado “2012”, sob a direção de Roland Emmerich, e lançado no Brasil em 13 de novembro de 2009.
} 
DO BRASIL, 2011). A participação previa a produção de um curta-metragem de até 1 (um) minuto com o tema " 2012 ".

O filme deveria, necessariamente, ser filmado nas dependências de um dos CCBBs e publicado na fan page do Centro onde a gravação fosse realizada. Haveria dois vencedores, por CCBB. Cada um ganharia uma viagem, com acompanhante, para conhecer os outros dois CCBBs, além de um Kit, contendo mala de viagem, camisetas e tablet. Dentre as regras, somente os participantes que curtissem as fan pages dos três CCBBs no Facebook e seguissem os três perfis dos CCBBs no Twitter estariam aptos a participar. Ou seja, havia um claro objetivo de ampliar o número de acessos às contas na rede social dos três centros. Para tanto, públicos geralmente excluídos de promoções não estavam impedidos de participar ("funcionários, contratados, estagiários e terceirizados do Conglomerado"). No entanto, venceriam os dois vídeos ${ }^{10}$ mais bem avaliados por Comissão Técnica e não com maior número de "curtidas", o que demonstrava preocupação não somente com o aumento de público em suas páginas, mas também com a qualidade do material apresentado no concurso.

\begin{abstract}
A valorização do hóspede e de sua singularidade pelo anfitrião transformase, na estratégia mercadológica, em segmentação do público. Já que não é possível considerar cada hóspede como indivíduo, busca-se considerá-lo incluído em grupos cuja procura do serviço hoteleiro é objeto de cuidados particulares. (CAMARGO, 2011, p.21-22)
\end{abstract}

Infere-se que a promoção visava ao público jovem, à época, mais afeito aos conclames das redes sociais, ao universo digital, e com um tema em voga no mundo, estimulava-se a criatividade e promovia-se o espaço cultural na internet. A produção apresentada, certamente, deve ter surpreendido a comissão julgadora.

Um dos ganhadores, o curta-metragem de Gustavo Serrate, intitulado "Em 2012 eu vou viver no CCBB", acompanhado pelo som de Ergo Phizmiz, mostra um homem que começa o dia na obra "Casulo", de Darlan Rosa, verificando a programação no livreto do CCBB. Em seguida, faz ginástica; bebe água; come um fruto colhido diretamente de uma árvore; sai de um dos sanitários, se seca, como se tivesse acabado de se banhar; entra no cinema para uma sessão; deita-se debaixo de uma árvore nem tão frondosa, com um guardachuva aberto, que o abrigam de uma pancada de chuva; passa pela fila da bilheteria; retira uma sacola/pertences do armário; observa uma pessoa lendo o que parece ser o cardápio do

\footnotetext{
${ }^{10}$ Os vencedores em Brasília foram "Em 2012 eu vou viver no CCBB", com direção e atuação de Gustavo Serrate, música de Ergo Phizmiz, "Trick me" - https://www.youtube.com/watch?v=cHS4145LakE - e "2012", produção, atuação e música: Artur Paschoali e Amanda Apen; câmera: Artur Paschoali, Amanda Apen e Danielle Aranha https://www.youtube.com/watch?v=i-ScDlaOD4c.
} 
bistrô; e retorna para o "Casulo", nele se deitando, como se fosse ali dormir. Vale citar, ainda, que ele assim descreve o trabalho: ""Eu vivo no CCBB", a força de expressão faz jús a (sic) realidade. Eu sempre estou por lá para pegar um filme, ver uma exposição, tomar um café." (SERRATE, 2012). Por outro lado, o título da música que o acompanha, "Trick me" "Engana-me", numa tradução livre -, deixa claro que é possível que tudo não passe do mito da caverna de Platão.

Ao propor habitar o que não é habitável, o artista mostra a natureza excêntrica do espaço, ao mesmo tempo em que provoca no espectador a consciência desse mesmo espaço. Como demonstra o vídeo, o Centro oferece uma hospitalidade utópica aos olhos do visitante, capaz de sentir atração até pelo nada fazer, pelo simples prazer de estar ali. O CCBB, com tudo o que o constitui, faz o indivíduo querer viver naquele espaço cercado de natureza e arte por todos os lados. É sua casa, onde se aprende a falar, brincar, amar, comer, se relacionar, mandar, obedecer. É o lugar de residência do exercício do poder. É reino do prazer.

Cabe ressaltar como o discurso da hospitalidade proferido pelo Centro vai impregnando as representações e o imaginário dos visitantes. Como visto, o vídeo reitera a receptividade em todos os espaços disponíveis: casulo, jardins, sanitários, bilheteria, cinema, bistrô. São as ações de acolhimento do CCBB sendo reconhecidas por quem o frequenta.

O segundo vídeo, com composição musical dos próprios criadores do curta, Artur Paschoali e Amanda Apen, traz um jovem vestindo figurino, usando óculos e corte de cabelo que remetem aos anos 1970, o que denota a atemporalidade dada ao espaço. Ele caminha por diversos ambientes interpretando as cenas sugestivas da letra da canção abaixo reproduzida:

Em 2012 tudo pode acontecer com você / Dizem que o mundo vai acabar / Dizem que se você não se cuidar / Comida de zumbi você pode virar / Mas isso não importa se você lembrar / Que o planeta não vai parar de girar / Enquanto todo mundo conseguir se amar / E de mãos dadas festejar! / Faça um pedido / Pra 2012! (PASCHOALI e APEN, 2012)

Nesse curta, os criadores apresentam a tão ensejada liberdade - pelos jovens. Naquele espaço, ele é livre e pode construir a própria história.

Tudo começa naquela soleira, naquela porta à qual se bate e que vai se abrir para um rosto desconhecido, estranho. Limite entre dois mundos, entre o exterior e o interior, o dentro e o fora, a soleira é etapa decisiva semelhante a uma iniciação. É a linha de demarcação de uma intrusão, pois a hospitalidade é intrusiva, ela comporta, querendo ou não, uma face de violência, de ruptura, de transgressão, até mesmo de hostilidade que Derrida chama de "hospitalidade". A soleira marca uma fronteira, uma passagem, e 
sua transposição implica tacitamente, para o convidado, a aceitação das regras do outro. [...] (MONTANDON, 2011a, p.32)

O estranho, o visitante, chega ao CCBB DF vindo do mundo exterior, de fora, em busca de outras experiências, de uma iniciação no universo de tudo o que o espaço oferece. $\mathrm{O}$ anfitrião, por sua vez, pensa e organiza o convite, a recepção e as atividades para o conforto desse intruso, do qual se desconhece a identidade. Uma vez, porém, dentro das fronteiras demarcadas pela soleira, o visitante sente-se senhor do espaço e apropria-se dele, rompendo, de certa forma, com o próprio anfitrião.

Aos poucos, o turista vai conhecendo e se reconhecendo no espaço geográfico, promovendo a complexa inter-relação social de que trata Moesch (2004), a interiorização psicologizante e dotada de simbolismo, como nos mostra Auraix-Jonchière (2011) e, principalmente, se apropriando do lugar, promovendo nele sua própria manifestação, em uma marcante forma de identificação e, consequentemente, prática social, na abordagem de Yázigi (2001).

O tão aclamado "sinta-se em casa" pode tornar o visitante indesejado, caso não aceite as regras do espaço - e ele tem inúmeras formas de fazê-lo. Em pesquisa por sites e jornais, além de consulta aos dados disponibilizados pela gerência do CCBB DF, até o momento, nenhum ato de vandalismo e depredação foi ali registrado ao longo de seus 15 anos de existência. A análise do fato é a de que o turista respeita as normas e, se as burla, o faz assumindo o posto de anfitrião.

Como alerta Foucart (2011, p.966), não se deve esquecer "que receber é, antes de tudo, satisfazer a uma lei que é a da arte". Desse modo, indaga-se qual o lugar do turista no CCBB?

A promoção Curta 2012 no $C C B B$ nos dá outro indicativo relativo à forma como o Centro se apresenta ao visitante. Os dois vídeos vencedores em Brasília mostram o espaço como acolhedor. Ambos trazem consigo a alegria de desfrutar dos ambientes com certa autonomia e independência, da forma como convém ao visitante, que, ali, sente-se em casa.

\subsection{A hospitalidade no limite da propriedade}

Nas informações gerais do Guia para formação e utilização de espaços culturais (CENTRO CULTURAL BANCO DO BRASIL, 1997) - a partir deste ponto, simplesmente Guia -, aconselha-se a utilização do nome da empresa patrocinadora, "a fim de assegurar maior visibilidade de sua marca e a direta associação da instituição com o benefício oferecido à comunidade" (op.cit., p.5). O documento recomenda, preferencialmente, o uso da expressão 
"Centro Cultural" em vez de "Espaço Cultural", quando atuar em segmentos diversificados e, no caso de abertura de espaço similar em outras cidades, que o nome adotado no primeiro local seja "mantido, de forma a garantir a uniformidade". (op.cit.). Trata-se do "nomesímbolo", "símbolo de sua singularidade e uma resposta à pergunta sobre quem ela [a pessoa] é a (sic) seus próprios olhos, ele [o nome] também serve de cartão de visita." (ELIAS, 1994, p.151).

Quanto à localização, o Guia destaca a facilidade de "acesso para veículos, pedestres e [...] boa rede de transportes públicos" (op.cit., p.6); recomenda o uso de "prédios de valor histórico e/ou arquitetônico reconhecidos"; além de manter sua apresentação "em excelente estado: pintura, revestimento, piso etc." (op. cit.). Tal contexto remete à reurbanização de áreas, o que leva ao pós-modernismo de Fredric Jameson e à lógica cultural do capitalismo tardio, como nos lembra o pesquisador Marco Estevão de Mesquita Vieira.

[...] A estratégia bem-sucedida de o Banco do Brasil se colocar como o banco do Brasil, como instituição comprometida com o desenvolvimento nacional e comunitário, passou a ser cobrada de forma efetiva sob o corolário da empresa patrimônio de todos e, portanto, da empresa a extrair as soluções generosas demandadas pela sociedade.

A apropriação da cultura pelo Banco do Brasil e a apropriação cultural do Banco do Brasil nos projetos de reurbanização das metrópoles brasileiras se inserem na lógica cultural do capitalismo tardio, conforme análise de Fredric Jameson sobre o pósmodernismo $^{11}$. [...] (VIEIRA, 2006, p.152)

Foi exatamente nesses moldes que o CCBB Brasília iniciou suas atividades, ostentando o nome do patrocinador Banco do Brasil, mantendo a expressão "Centro Cultural", por sua característica de espaço multidisciplinar, e a preocupação com o acesso (HENRIQUE, 2000). Ainda que possua amplo e privilegiado estacionamento para automóveis e, embora atualmente existam mais linhas regulares de ônibus passando pela região, o ingresso de pessoas que dependem do transporte público é facilitado pelo ônibus, gratuito, que o próprio CCBB disponibiliza, nos dias de seu funcionamento, com paradas em pontos estratégicos da cidade. Sobre os cuidados com a aparência, a manutenção do Centro encarrega-se desses afazeres. Afinal, é preciso receber os convidados com estilo e, "em certas condições, uma casa hospitaleira pode mesmo se tornar sedutora" (SMOLIAROVA, 2011, p.442).

\footnotetext{
${ }^{11}$ JAMESON, Fredric. Pós-modernismo: A lógica cultural do capitalismo tardio. São Paulo: Ática, 2000.
} 
Assim, pode-se supor que habitantes tanto do Plano Piloto quanto do entorno de Brasília acessem o Centro Cultural, bem como visitantes de outras cidades brasileiras e até estrangeiros de passagem pela capital. Afinal, o CCBB é um lugar do qual o brasiliense orgulha-se e no qual se sente em casa. E a arte tem seu quinhão nessa sedução:

O mundo moderno considera a arte muito importante - quase como o sentido da vida. Prova desse grande apreço se vê na abertura de novos museus, na canalização de importantes recursos públicos para a produção e exposição de obras de arte, no desejo dos guardiões da arte de aumentar o acesso a essas obras (principalmente para crianças e minorias), no prestígio das teorias acadêmicas e nos altos valores do mercado de arte. (BOTTON e ARMSTRONG, 2014, p.4)

Identificar-se com o cliente por meio de atributos não-negociais ou simbólicos que sejam representativos do seu quadro de valores é uma maneira de a marca se posicionar no mercado. E uma casa atraente, arrumada e especial, sede do início de renomados eventos, pode significar um começo favorável.

Mas foi necessário um esforço conjunto, ainda que não declarado, entre a coordenação do espaço e o público para transformar o CCBB Brasília em lugar atrativo para a estreia dos eventos. Sob o título "Paula Sayão fala em entrevista sobre sua administração do CCBB", os repórteres do Correio Braziliense, Irlam Rocha Lima e Ricardo Allan, registraram, dentre outras, a seguinte declaração da gerente Geral do Centro Cultural, Paula Sayão:

“[...] as estreias projetam Brasília num cenário nacional. Antes, havia uma briga para manter essa proposta porque as produções não queriam. Tinha um clima de "deus me livre", de ser um ensaio geral. Agora, muitas fazem questão de colocar na proposta Brasília como um começo, até porque os artistas perceberam o quanto o público brasiliense é criterioso. Cada centro cultural tem sua especificidade, a nossa é de renovar e ampliar o público. Nesse sentido, as estreias nacionais são imprescindíveis e temos a nossa cota" $^{\prime 2}$. (LIMA e ALLAN, 2012)

Percebe-se que Brasília não chegou conquistando de imediato os artistas e os habituados produtores. Os anfitriões (CCBB e público) precisaram esforçar-se para agradar outro convidado ilustre: as produções nacionais de mostras e espetáculos.

[...] Artistas costumam ter [...] visões que enriquecem a percepção da realidade. [...] Cabe às rotinas do planejamento ter a sensibilidade de captar o que certos destaques têm a nos dizer e saber contextualizar o recado onde couber. (YÁZIGI, 2001, p.248)

\footnotetext{
${ }^{12}$ A entrevista foi publicada no caderno Diversão \& Arte em 10 de junho de 2012.
} 
Foi preciso deixar fluir a alma do lugar para que o CCBB DF se tornasse ponto de referência.

Outro estudioso, Serpa, alude ao famoso ensaio de Walter Benjamin, "A obra de arte na era da sua reprodutibilidade técnica", para afirmar que a obra reproduzida se emancipa e passa a existir justamente para sua reprodução.

[...] Pode-se generalizar dizendo que a técnica da reprodução destaca do domínio da tradição o objeto reproduzido. Ao multiplicar a reprodução, coloca, no lugar da existência única da obra, uma existência em série. Isso vai permitir a reprodução vir ao encontro do espectador, sempre atualizando o objeto reproduzido. Esses dois processos vão resultar, finalmente, num violento abalo da tradição. (SERPA, 2014, p.18)

Correndo-se o risco de forçar uma conexão, pode-se deslocar o conceito acima para a reprodutibilidade do modus operandi do CCBB Rio de Janeiro para as demais praças. Há um protótipo e suas reproduções, com características e concepções próprias, adequadas a cada cidade que, consequentemente, diferenciam-se umas das outras. Afinal, a reprodução de uma obra jamais será como o original.

Com o objetivo de dimensionar o espaço ocupado pelo CCBB Brasília, cabe destacar que o prédio possui aproximadamente $20.551 \mathrm{~m}^{2}$ de área construída, ocupando $7.000 \mathrm{~m}^{2}$ desse total (dados anteriores ao início das obras do Museu, os quais ainda não foram disponibilizados), além de uma área externa, composta por jardins e amplo estacionamento, com $23.940 \mathrm{~m}^{2}$. Apenas como comparação, o CCBB Rio de Janeiro possui $19.243 \mathrm{~m}^{2}$ de área construída, ocupando $15.046 \mathrm{~m}^{2}$ desse total; o CCBB SP ocupa integralmente seus $4.183 \mathrm{~m}^{2}$, enquanto o CCBB BH, com suas instalações ainda incompletas, ocupa $8.000 \mathrm{~m}^{2}$ dos $12.000 \mathrm{~m}^{2}$ de área construída (BANCO DO BRASIL, 2013a). Como é possível observar, apesar de polo econômico e zona de importância central no relacionamento com o cliente, o CCBB SP possui as menores medidas, o que muitas vezes o impede de receber integralmente mostras exibidas nos demais centros. O fato levou gestores daquele módulo a propor

[...] o aproveitamento do Complexo Umberto Primo, localizado próximo à Avenida Paulista, como centro cultural. [...] o Complexo, de acordo com a proposta apresentada em estudo, abrigaria o "Quarteirão Banco do Brasil", que, além da criação de espaços culturais, contemplaria unidades regionais do Conglomerado Banco do Brasil, tais como a Universidade Corporativa, Agência de Negócios "Corporate", Fundação Banco do Brasil, sem esquecer dos serviços de restaurantes, casa de chá, cafeterias, lanchonetes e centros de convenção, entre outros. (VIEIRA, 2006, p.215-216) 
O projeto não seguiu adiante por determinação da Diretoria de Marketing e Comunicação do Banco do Brasil (atualmente Diretoria Estratégia da Marca), à qual pertencem hierarquicamente os CCBBs. Uma das dificuldades de ampliação do Centro na capital paulista pode estar relacionada aos altos custos de tal implementação, uma vez que os valores envolvendo a reforma do prédio que ora abriga o CCBB BH foram da ordem de $\mathrm{R} \$ 37$ milhões (BANCO DO BRASIL, 2013b). O edifício ${ }^{13}$, ao redor da Praça da Liberdade, não pertence ao Banco do Brasil, tendo sido cedido em forma de comodato por 30 anos, assim como os edifícios históricos que compõem o chamado Circuito Praça da Liberdade. No caso de Brasília, para adaptar o Centro de Treinamento em Centro Cultural, no ano 2000, como visto, foram cinco meses de obras e R\$1,4 milhão de investimento. (MACIEL, 2000, p.20). Treze anos mais tarde, o aporte previsto para os projetos e as obras físicas de infraestrutura para a adaptação das salas do primeiro andar do Edifício Tancredo Neves em museu é estimado em R \$ 3,5 milhões, enquanto curadoria e montagem da exposição permanente têm orçamento de cerca de $\mathrm{R} \$ 5,5$ milhões. (BANCO DO BRASIL, 2013)

Simultaneamente ao compromisso de realizar lucros operacionais consistentes, o Banco do Brasil defende a realização de investimentos para a promoção da cidadania, incentivando ações no âmbito da responsabilidade social, da cultura, da ética. (ZAGHEN, 2000, p.5)

Retomam-se as palavras do presidente da instituição à época da inauguração do CCBB de Brasília para ressaltar que, ao gerir e manter tal estrutura, subentende-se que a orientação da instituição para sua associação com a cultura seja de perenidade nas ações de promoção dos empreendimentos ditos culturais. Entretanto, na "condição de empresa pública, condicionada às orientações do Governo Federal, a influência política sempre pesou nas decisões da Empresa, inclusive na ampliação dos CCBB”. (VIEIRA, 2006, p.219). O autor lembra que, no final de 2002, houve uma "ação política da elite pernambucana, que se uniu, conforme estudo realizado por Rogério Proença de Sousa Leite ${ }^{14}$, para tornar a capital o portal de entrada turístico, cultural e econômico do Nordeste" (Vieira, 2006, p. 219). A inauguração, prevista para 2004, não ocorreu devido a "pendências entre as partes" (op.cit, p.220). A experiência levou o Banco, em 2003, a "estabelecer um modelo de análise para avaliar as

\footnotetext{
${ }^{13}$ O prédio que abriga o CCBB de Belo Horizonte foi projetado em 1926, pelo arquiteto Luiz Signorelli, para integrar o complexo do serviço público no estado de Minas Gerais.

${ }^{14}$ Espaço público e política dos lugares: Usos do patrimônio cultural na reinvenção contemporânea do Recife Antigo, tese de doutorado defendida no Departamento de Antropologia do Instituto de Filosofia e Ciências Humanas da Universidade Estadual de Campinas, em 2001.
} 
propostas de expansão da rede" e "pelo menos, reforçar o seu poder de negociação ante as 'recomendações' que vinham de cima." (op.cit., p. 221).

\begin{abstract}
A discussão sobre a margem de contribuição das atividades mercantis para a sociedade sempre esteve em pauta na estratégia corporativa do Banco do Brasil. Essa atitude, bastante sedimentada ao longo da história, hoje está se tornando poderoso diferencial competitivo, que nos distingue de nossos concorrentes. O olhar atento dos cidadãos sobre as questões de nosso cotidiano difunde a cobrança cada vez maior junto às empresas, por ações socialmente responsáveis. No Banco do Brasil esse é um valor presente de forma marcante nas relações entre seus funcionários, clientes e acionistas. $\mathrm{O}$ princípio da responsabilidade social orienta e estimula os projetos voltados para a cidadania e cultura, aprimorando o percurso da empresa com os destinos do país. (ZAGHEN, 2000, p.5)
\end{abstract}

Desde sua inauguração, o CCBB Brasília desenvolve projetos no intuito de cumprir seu papel de inserir a capital do País no roteiro nacional dos eventos e produções culturais, ao ponto de seguir figurando como o segundo museu/centro cultural mais visitado no Brasil e $43^{\circ}$ no mundo, ao registrar 1.215.763 visitantes no ano de 2012. O primeiro lugar ficou com o CCBB Rio de Janeiro, que se manteve como o $17^{\circ}$ espaço cultural mais visitado do planeta, totalizando um público de 2.235.354, com o CCBB SP assegurando a terceira posição no país e caindo para a $65^{\mathrm{a}}$ dentre os países pesquisados, ao registrar 971.005 visitadores. (THE ART NEWSPAPER, 2013, p.29).

No exercício de 2013, as posições internas não se modificaram. No entanto, o espaço brasiliense foi o único nacional a subir dez posições, dentre os centros/museus dos países listados, ocupando o $33^{\circ}$ posto, ao receber um total de 1.468 .818 visitantes. O CCBB RJ caiu para a $21^{\text {a }}$ posição, com 2.034.397 pessoas, e o de São Paulo para o $69^{\circ}$ lugar, registrando 931.639 visitantes. (THE ART NEWSPAPER, 2014, p.15).

Apesar de assinalar um público ligeiramente superior ao do ano anterior, com 1.476.744 visitadores em 2014, o Centro sediado na capital federal passou ao terceiro lugar dentre os espaços dedicados às exposições de arte no Brasil, com a vice-liderança ficando com o Instituto Tomie Othake, em São Paulo (THE ART NEWSPAPER, 2015, p.15). Por outro lado, pela primeira vez, figurou entre os 20 espaços a receber as mostras mais populares do globo, ocupando o $11^{\circ}$ lugar no mundo pela exibição de "Obsessão Infinita", de Yayoi Kusama. A mostra, sozinha, levou ao CCBB DF uma média diária de 7.957 visitantes, totalizando 471.730 pessoas ao longo de 78 dias de exposição (19 de fevereiro a 28 de abril de 2014) (op.cit., p.3). Os avanços não foram suficientes para alavancar o Centro, que caiu cinco posições em relação a 2013, chegando ao $38^{\circ}$ lugar no mundo (op.cit., p.15). No ano de 
realização da Copa do Mundo de Futebol no Brasil, o CCBB SP ocupou o quinto posto no país, sendo ultrapassado pelo Museu Nacional de Brasília mantendo, entretanto, a $69^{\mathrm{a}}$ posição no mundo. O primeiro lugar no Brasil se manteve com o CCBB RJ, que agora detém o $20^{\circ}$ posto no planeta, com 2.399 .832 visitantes.

Vale o registro de que, em 2014, o Centro carioca bateu seu próprio recorde de visitação de uma única mostra, ao receber "Salvador Dalî" (BANCO DO BRASIL, 2014). A exposição mais vista em 25 anos de CCBB recebeu 973.995 visitas (THE ART NEWSPAPER, 2015, p.3). Para se ter uma ideia desse público, a última grande retrospectiva internacional do espanhol ocorreu em 2012, em Paris, no Centro George Pompidou, com público de 790 mil visitantes. Vale destacar ainda que, enquanto na França, a curadoria dedicou-se a apresentar uma retrospectiva das diversas fases do artista, no Brasil, ela se debruçou por sua obra surrealista e, mesmo antes de chegar ao CCBB, já gerava expectativas na imprensa (FURLANETO, 2014).

Paradigma para o marketing cultural das empresas e, especialmente nos casos de Rio de Janeiro e São Paulo, para a requalificação dos centros urbanos, indubitavelmente, o Centro Cultural Banco do Brasil está presente em qualquer análise ou consideração que se faça sobre museus e/ou centros culturais no Brasil. Mas o que, afinal, teria levado o maior banco do País a criar um espaço próprio voltado para as artes? Parte da resposta encontra-se no Guia, o qual indica que, para manter-se no mercado, não basta a uma empresa prestar ao consumidor serviços de qualidade; nos tempos modernos, ela precisa "mostrar-se indispensável, integrada ao meio, co-responsável pelo ambiente onde atua" e que "a realização de eventos que valorizem as manifestações artísticas e culturais nas diversas regiões do País" é uma das mais exitosas formas "de se estreitar o nível de relacionamento com a comunidade" (CENTRO CULTURAL BANCO DO BRASIL, 1997, p.3).

O Banco do Brasil (BB), em seu site, endossa que seus quatro centros culturais correspondem a "ação de responsabilidade social relevante para o País" (BANCO DO BRASIL, 2013b). Um exemplo contumaz pode ser atribuído ao Programa Educativo, responsável pelo atendimento diário de crianças e adultos, seja individualmente ou em grupo, por meio de visitas mediadas às exposições e condução de atividades diversas, sempre com acesso grátis. Para as crianças das escolas públicas, um ônibus é disponibilizado para buscálas e levá-las em segurança para um passeio pelo mundo encantado e revelador das artes. Talvez por atiçar tal curiosidade, é que Souza (2011) tenha se referido a esses estudantes como "crianças comportadas [...] sempre presentes nos programas educativos". 
Fato é que, ao dedicar à cultura um amplo espaço, o Banco do Brasil identifica-se com ela - e com o lugar que esta ocupa no imaginário do cidadão, construindo sua imagem de “empresa-cidadã” (CENTRO CULTURAL BANCO DO BRASIL, 1997, p.3) e hospitaleira.

\subsection{Para além das instalações}

Nesta pesquisa, tem-se o CCBB Brasília como o lugar para onde as pessoas se deslocam, saem de suas casas para ir até ele acompanhar seu calendário próprio de eventos. Desse modo, extrapola sua função de atração turística ou polo atrativo, pois não é simplesmente um destino pelo qual o cidadão passa e vê. Trata-se de lugar ou espaço dotado de personalidade, de infraestrutura básica, com atrativos qualificados, sedimentados no pilar da interseção informação-cultura-turismo-consumo-turista.

[...] A cultura de uma determinada localidade é reconhecida também pela sua hospitalidade que é oferecida e expressada nas formas de tratamento pessoal e agradecimentos. Fica exposto o fato de que os atos de comunicação têm estreita relação com as atitudes hospitaleiras de uma determinada localidade. (NEVES e ALEXANDRE, 2006, p.8)

No CCBB, observa-se a existência de uma relação conspícua de hospitalidade, pois, ainda que disperso em suas formas (paisagem, trabalhadores, eventos), há o dono da casa que convida e recebe o visitante, aquele que vem do exterior e está de passagem. Como lembra Grassi:

[...] O espaço a ser penetrado pode ser um espaço geográfico - em seus dois componentes, urbano e doméstico - ou um espaço psíquico - a penetração num território, o território do outro. Os dois são ligados, pois, no mais das vezes, todo território geográfico implica um território da alteridade. O gesto de hospitalidade não é nem confortável nem espontâneo. Na origem, no mundo greco-romano, ele resulta de um dado político e social ligado ao status do estrangeiro na cidade. [...]" (GRASSI, 2011, p.45)

Nesse ínterim, o CCBB constrói sua identidade enquanto lugar e como espaço que recebe grupos e indivíduos, tornando-se um lugar em que se efetiva a prática turística: "Turismo é você propiciar ao turista a experiência de ser protagonista" (BENI, 2014).

Trata-se do zelo do hospedeiro, das múltiplas atenções que aquele que recebe dedica, e claro, de bom grado ao visitante, mas que nem por isso deixam de ser uma obrigação. A própria presença do convidado, por mais desejada que seja, o prazer da festa proporcionado pelo estranho [...], subjugam o espírito, e a intrusão desejada não deixa de ser intrusão. O convidado esperado ocupa física e psiquicamente o espaço e o tempo: ele 
exige, para quem recebe, uma responsabilidade, uma obrigação, que é o cerne mesmo da hospitalidade. (MONTANDON, 2011a, p.33)

A programação do $\mathrm{CCBB}$ DF e dos demais centros culturais Banco do Brasil, em grande parte, é definida a partir das propostas aprovadas no Edital CCBB, lançado anualmente até 2012 e, desde então, a cada dois anos. Por meio do processo de seleção pública, com inscrições gratuitas, são recebidas propostas de patrocínio e de cessão de espaço para projetos culturais a serem realizados em suas dependências ${ }^{15}$.

No entanto, os editais constituem uma prática adotada a partir da década de $1990^{16}$. Até então, a programação era vislumbrada por funcionários do Banco lotados no CCBB Rio de Janeiro, além de contar com produtores culturais atentos às demandas do patrocinador. $\mathrm{O}$ respeito conquistado pela seleção de eventos que primassem pela qualidade tornou-se um legado do primeiro Centro.

A oficialidade da chancela Banco do Brasil, com seus atributos de segurança e solidez, fazia dos três CCBB os parceiros ideais de embaixadas, consulados e demais instituições estrangeiras que desejassem promover exposições ou mostras. [...] (VIEIRA, 2006, p.213-214)

Esse modelo de gestão foi crucial para a formatação e a construção da ideia geral sobre o CCBB no imaginário popular. Por imaginário entende-se um "sistema de ideias e imagens de representação coletiva que os homens, em todas as épocas, construíram para si, dando sentido ao mundo" (PESAVENTO, 2008, p.43). Em editorial do jornal Correio Braziliense de 2003, para celebrar os três anos do espaço cultural na cidade, o enaltecimento remetia a um ideário:

A qualidade da programação do CCBB remete-nos a pedaços da Europa; lembra-nos bons momentos no CCBB dos cariocas; dá orgulho de morar em Brasília. E aí está um sentimento que o brasileiro tem uma dificuldade enorme de lidar.

E o CCBB é um desses raros lugares municiados com verbas governamentais que resgatam o que poderíamos chamar de "bom patriotismo". É daqueles que mostram que o apoio do Estado pode ser

\footnotetext{
15 "Os projetos serão avaliados pelas equipes técnicas dos Centros Culturais Banco do Brasil e, posteriormente, por representantes da sociedade civil com notório reconhecimento no meio cultural e acadêmico. [...]" (BANCO DO BRASIL, 2012) ${ }^{16}$ Não foi possível precisar a data exata do lançamento do primeiro edital público, mas apurou-se que, desde 1991, o CCBB Rio de Janeiro recebe projetos para análise. No intuito de padronizar a forma como chegavam os projetos, foi criado, em 1995, um formulário de encaminhamento de propostas.
} 
benéfico e que podemos - sem qualquer constrangimento - ter orgulho desse país.

$[\ldots]$

Somos capazes de realizar exposições sofisticadas e de exportar o combustível mais requisitado do planeta. Somos capazes de adquirir tecnologia de lançamento de foguetes. E muito mais. Seremos bárbaros quando esses fatos dominarem a cena. (CORREIO BRAZILIENSE, 2003)

Se a programação e o próprio acesso ao CCBB DF outrora pudessem ser considerados privilégio, insígnia de classe abastada e fator de distinção entre estratos sociais, os números crescentes de público nos últimos anos, como visto, parecem indicar que o fenômeno do acolhimento atingiu outras camadas, sendo atualizado pelo imaginário mobilizado das relações sociais.

Com a adoção do edital, modelo de transparência e democratização do acesso de produtores e, por que não, do público, são explicitados os critérios de seleção e o eixo curatorial, norteadores da programação do próximo biênio, além de comunicada a composição da comissão de seleção (BANCO DO BRASIL, 2014a). O resultado do edital é publicado em seu site, nas redes sociais, e divulgado pelos veículos de comunicação. Destarte, o público sabe, de antemão, parte do que verá nos espaços dos CCBBs.

O principal critério - além da qualidade - para a escolha dos eventos é que venham ao encontro dos valores da comunidade, com assuntos que despertem o interesse ou que preservem as raízes e a memória locais. (CENTRO CULTURAL BANCO DO BRASIL, 1997, p.3)

Esse modelo de operação, o edital, adotado pelos CCBBs, não é unanimidade, e sofre arguições de parte da crítica especializada. Ao delegar aos produtores culturais a apresentação de projetos, os centros deixam-se dominar pela "lógica do marketing", ao invés de se "pensar uma programação coerente, baseada na pesquisa e na continuidade”. (CYPRIANO, 2014). Essa "ditadura dos produtores culturais" estaria promovendo, de acordo com essas análises, exposições fast food, realizadas com pressa, sob o efeito apenas da capitalização de público.

No entanto, mesmo com a realização do edital, o que possibilita que produtores de todas as regiões do País mostrem suas propostas e tenham a oportunidade de circular por importantes centros urbanos, abrindo caminho para o reconhecimento fora de seus estados de origem, espaços abertos são deixados para serem preenchidos por propostas de ocasião, que mantenham o Centro como um dos lugares preferidos dos brasilienses: 
É facultada ao CCBB a prospecção de até 30\% (trinta por cento) dos projetos que irão compor suas grades de programação para o período. As prospecções são escolhas diretas de projetos, realizadas por iniciativa exclusiva dos Centros Culturais Banco do Brasil, visando a compor o eixo curatorial definido, não havendo inscrição de projetos para esta modalidade. (BANCO DO BRASIL, 2012)

Desse modo, o CCBB também se impõe a premissa de seleção direta. O mercado é dinâmico e oportunidades são vislumbradas pelo CCBB com o objetivo de atingir o público, mantendo as conquistas da marca.

Outra vertente da crítica credita haver uma preocupação excessiva com a afluência de público.Tal fato se observa, tendo em vista que, para legitimar-se internamente, o CCBB procura atender as expectativas de retorno do seu mantenedor e a quantificação do público é um importante quesito, além das matérias e notas nos jornais. A mensuração de visitantes "evidencia (em princípio) o retorno simbólico obtido com a arte exposta com a chancela e o logotipo da empresa". (SOUZA, 2013, p.233).

O retorno do investimento em cultura é representativo, como apresentado na reportagem de O Estado de S. Paulo:

O Banco do Brasil consegue lucrar com mídia espontânea até 18 vezes o valor que investe nos patrocínios culturais. No ano passado [2014], o maior banco do país aportou $\mathrm{R} \$ 49,3$ milhões em projetos de cultura. O retorno em reportagens que mostravam a marca do banco atrelada aos eventos chegou a $\mathrm{R} \$ 900$ milhões, segundo estimativa de uma consultoria contratada pelo banco. (ALVES, 2015)

A matéria prossegue, e compara os números da cultura com os do esporte, outro segmento de patrocínio adotado pelo BB visando ao fortalecimento da marca. "Nos aportes em modalidades esportivas, como o vôlei, o retorno é de duas vezes o investido. Em alguns casos, chega a três e meio, como no handebol." (op.cit.)

Até o edital de seleção pública de 2012, que contemplou projetos a serem realizados em 2013/2014, o processo de seleção era direcionado apenas a patrocínios, ou seja, as propostas contempladas receberiam apoio financeiro do Banco do Brasil. Em outubro de 2013, a instituição inova, ao lançar um edital exclusivo, objetivando a cessão de espaço (BANCO DO BRASIL, 2013c). O CCBB, como visto, sempre foi procurado por inúmeros produtores, incluindo embaixadas, consulados e outras instituições, para receber seus eventos, sem necessidade de patrocínio por parte da mantenedora. A medida, portanto, amplia o acesso dos interessados em ocupar os "nobres" espaços dos CCBBs. 
No ano de 2014, visando à composição das programações dos CCBBs em 2015/2016, mais novidades. Pela primeira vez, o Banco do Brasil abriu, simultaneamente, dois editais para receber propostas de patrocínios: o denominado Edital de Patrocínio Banco do Brasil, lançado anualmente, e que abarca projetos ambientais, sociais, culturais, negociais a serem realizados em qualquer lugar do País, incluindo as cidades com CCBB - desde que a proposta não seja para realização em um dos centros culturais do Banco - e o Edital de Patrocínio e Cessão de Espaço 2015/2016 (Edital CCBB), posto ser exclusivo para a programação dos seus centros culturais. Ainda havia o incipiente Prêmio CCBB Contemporâneo, integralmente destinado às artes plásticas. Essa novidade tinha por objetivos "reconhecer, estimular e difundir trabalhos inéditos de artistas brasileiros", ao premiar até 10 (dez) trabalhos originais, com possibilidade de compor a programação do CCBB Rio de Janeiro e até de circular com as obras pelos demais CCBBs, "a critério do Banco do Brasil” (BANCO DO BRASIL, 2014b). Interessa ao andamento da pesquisa o entendimento do funcionamento do CCBB DF; por esse motivo, nossa referência ao edital anual termina aqui, bem como as decorrências do Prêmio.

O Edital CCBB é composto por duas modalidades, a de Patrocínio, cujas propostas selecionadas dependem e contam com apoio financeiro do Banco, e a de Cessão de Espaço, cujos projetos já devem possuir os recursos necessários para sua realização, desde que não envolvam empresas concorrentes do conglomerado Banco do Brasil. Em ambos os casos, os projetos devem ser inéditos. As áreas e os segmentos são indicados no Edital: Artes Cênicas (circo, dança, eventos multidisciplinares, festival, ópera, teatro - adulto e infantil); Cinema (festival, eventos multidisciplinares, mostra temática); Exposição (coletiva, coletivo estabelecido, contemporânea, dupla, eventos multidisciplinares, histórica, individual, temática); Ideias (curso, debate, eventos multidisciplinares, palestra, seminário, workshop / oficina); Música (série musical nacional, série musical internacional); e Programa Educativo (arte-educação, contação de estórias).

O Edital explicita também a política de ingressos praticada pelo CCBB. O patrocinado nas áreas de Artes Cênicas, Cinema, Ideias e Música recebe também o valor da bilheteria, já descontados impostos e taxas, sendo os projetos de Exposição e Programa Educativo, necessariamente, gratuitos. O valor do ingresso, sempre a preços populares, deve seguir o valor praticado pelos CCBBs, incluindo os critérios de meia-entrada. Para o produtor e o público que serão recebidos, acolhidos pela casa, as regras estão postas com lisura e clareza, muito antes da estreia do projeto.

A recomendação de se fazer um edital de seleção pública não constava com essa nomenclatura no referido Guia, apesar de este sugerir ao local a criação de um cadastro de 
expositores, com entrevista, portfólio e currículo, não deixando de comunicar ao proponente a existência de uma seleção de projetos.

[...] Hoje em dia, uma reflexão sobre a hospitalidade pressupõe, entre outras coisas, a possibilidade de uma delimitação rigorosa das soleiras ou fronteiras: entre o familiar e o não-familiar, entre o estrangeiro e o nãoestrangeiro, entre o cidadão e o não-cidadão. Mas primeiramente entre o privado e o público [...]. (DERRIDA, 2003, p.43)

No CCBB, a prática dos editais foi motivada pela necessidade tanto de organização quanto de democratização do acesso, além de transparência - cabe lembrar que o Banco do Brasil é uma empresa pública de economia mista.

\subsection{Banco do Brasil}

Em março de 1808, a família real portuguesa, sob o comando do príncipe regente D. João, instalou-se no Rio de Janeiro, após fugir das tropas napoleônicas que invadiam Portugal. A colônia passava a ser a sede do império e uma série de medidas estava sendo adotada para sua administração: abertura dos portos às nações amigas, criação de ensino superior, incentivo à indústria (com a revogação do alvará de 1785, que proibia as fábricas e manufaturas em solo brasileiro), inauguração da imprensa régia, da Academia da Marinha e do Banco do Brasil.

A criação da entidade, no entanto, partiu da necessidade da própria Corte de financiar despesas governamentais. E, assim, em 12 de outubro de 1808, o príncipe regente D. João assinava um alvará, instituindo o primeiro banco do Brasil. Ironicamente, foi essa a primeira instituição financeira criada sob os domínios portugueses, sendo a quarta, no mundo, na condição de emissor de papel-moeda. Até então, somente Suécia, França e Inglaterra possuíam bancos emissores. Apesar de o documento firmado por D. João ressaltar tanto seu caráter público quanto sua função de impulsionar a economia com a oferta de crédito, o Banco do Brasil nascia sem dinheiro, contando com a captação de recursos privados para iniciar suas atividades (BANCO DO BRASIL, 1988).

Passados mais de 200 anos, o Banco do Brasil está presente em 99,8\% dos municípios brasileiros (agências, caixas eletrônicos e Banco Postal), é uma empresa de economia mista (sociedade anônima - S.A.) controlada pela União e listada desde 2006 no Novo Mercado da BM\&FBOVESPA, segmento que reúne as companhias com as melhores práticas de governança corporativa, com cerca de 111 mil funcionários, mais de 61 milhões de clientes, sendo "a maior instituição financeira da América Latina em termos de ativos" (BANCO DO 
BRASIL, 2015a), e com diversos prêmios de reconhecimento dessas condutas ${ }^{17}$. "Como um dos principais agentes dos desenvolvimentos econômico e social do País e de políticas públicas", o BB atua "de forma responsável para promover a inclusão social, por meio da geração de trabalho e renda" (BANCO DO BRASIL, 2015b).

A história do Banco do Brasil, além de retratar o desenvolvimento da banca brasileira, espelha a trajetória do capitalismo no Brasil e o embate travado entre desenvolvimentistas e monetaristas, confronto que ao longo do tempo expõe o ritmo errante da economia brasileira, a carência de capitais e a imprecisão de limites das esferas pública e privada.[...] (VIEIRA, 2006, p.103)

Sendo assim, entende-se que enveredar mais e mais pela história da instituição afastaria a pesquisa de seu interesse crucial, o discurso de acolhimento contido no convite para o visitante do CCBB Brasília. No imaginário popular, bancos costumam ser instituições austeras, autocentradas nas suas atividades de prestação de serviços financeiros e, dessa feita, desinteressadas em iniciativas que não remontam à premissa da hospitalidade.

A gênese, a expansão e a manutenção de centros culturais apontam para outro caminho. Todavia, não há como negar que a lógica do sistema de gestão bancária influencia a organização do trabalho cultural do CCBB. Afinal, o patrocínio é praticado "não apenas como exposição da marca, mas também como estratégia de negócio”. (ALVES, 2015)

Em sua tese de doutorado, Vieira demonstra, contrariando a expectativa inicial,

[...] que mais de $60 \%$ do público freqüentador dos CCBB não possuem vínculos negociais com o Banco do Brasil; que a Empresa é vista como extensão do Estado e, portanto, com o senso comum de uma atuação "desinteressada", "sem pedir nada em troca", o que lhe granjeia grande estima e admiração, mas não lhe retorna os dividendos desejados; que o uso político, mais que o estratégico, valida a expansão dos CCBB e que o marketing cultural não deve ser prioridade, na opinião pública, nas ações de responsabilidade socioambiental dos bancos. (VIEIRA, 2006, p.05)

Hierarquicamente, o CCBB obedece às recomendações da Diretoria de Estratégia da Marca, responsável por toda a área de marketing do Banco do Brasil, dentre outras atribuições. "A importância mercadológica do segmento cultural já não deixa dúvidas diante

\footnotetext{
${ }^{17}$ Citam-se apenas algumas premiações recebidas no ano de 2015, posto serem consecutivas: reconhecido pelo segundo ano pelo instituto norte-americano Ethisphere uma das empresas mais éticas do mundo; pela $25^{\text {a }}$ vez o banco mais lembrado pelos brasileiros, de acordo com Top of Mind da Folha de S.Paulo; pela quarta vez, integrante do Índice Dow Jones de Sustentabilidade da Bolsa de Nova Iorque (DJSI, na sigla em inglês), pela RobecoSam Sustainability Investing, e que ainda identificou o $\mathrm{BB}$ como um dos oito bancos mais sustentáveis do mundo em responsabilidade corporativa no livro "The Sustainability Yearbook 2015". No que se refere à educação, posto que o CCBB DF nasceu no ambiente do Centro de Formação Banco do Brasil, vale destacar que a Universidade Corporativa Banco do Brasil (UniBB) foi eleita pela comissão julgadora do instituto europeu Global CCU (Global Council of Corporate Universities - www.globalccu.com) como a "melhor universidade corporativa do mundo", com o BB sendo reconhecido no Brasil como "Top of Mind RH 2015", como empresa com melhores práticas de educação corporativa/e-learning.
} 
de um movimento de público cada vez mais amplo" (VIEIRA, 2006, p. 193), como se observa em levantamentos como os do já citado The Art Newspaper e nos divulgados pelo Ministério da Cultura (MinC). Nesses, o Banco do Brasil figura entre os primeiros colocados dentre os maiores investidores em cultura, por meio da Lei 8.313/91, mais conhecida como Lei Rouanet: quarto lugar em 2012; terceiro em 2011 e 2013, e primeiro lugar em 2014 (MINISTÉRIO DA CULTURA, s/d).

[...] O mecenato é apresentado como uma forma de humanizar a imagem das empresas, uma vez que os clientes e demais públicos não vêem apenas o lado comercial da empresa, mas também o seu lado humano, a sua responsabilidade social. [...] (VIEIRA, 2006, p.193)

Como esclarece Vieira, o investimento em cultura passou a ser um instrumento efetivo de contato com a coletividade; ele reforça a marca da empresa e é importante tática negocial. Em outras palavras, a atuação do BB vai bem além das vantagens de abatimento da Lei Rouanet. Do total de recursos investidos nos CCBBs em 2014, R\$ 118.804.658,60, somente $\mathrm{R} \$ 46.710 .149,17$ receberam os benefícios fiscais do mecenato. O montante maior, portanto, é oriundo de investimento próprio $^{18}$ (BANCO DO BRASIL, 2015a, p.121).

Se a hospitalidade deve ser entendida como o dentro que se abre para fora, como o íntimo que se abre ao outro, a soleira (seuil) constitui seu espaço próprio, um espaço ambíguo, e assim um espaço perfeito para uma literatura fantástica que ama o entremeio no qual se misturam o real e o imaginário. [...] O espaço do maravilhoso, em contrapartida, por mais estranho e exótico que seja, se acompanha da aceitação sistemática, e é imediatamente admitido e compreendido pelo personagem e pelo leitor na medida mesma em que ele dá, à maneira de um convite, as chaves de sua compreensão: Alice permanece bem-vinda no País das Maravilhas... Assim é preciso compreender o fantástico como um gênero que se dá um espaço e empreende ao mesmo tempo sua violação. (PRINCE, 2011, p.855)

No fantástico mundo dos negócios, o espaço, a arte e o visitante integram a poética do gênero pelo fato de representar, de uma maneira ou de outra, o objeto último do desejo. $\mathrm{O}$ anfitrião, o Banco, que pode ser temido em meio a diversos serviços que oferece, na cultura, é hospedeiro ideal, ao conceder ao outro o desfrute da programação. Nathalie Prince lembra a importância da polissemia do termo "hóspede/hospedeiro", em francês. Segundo ela, "esse hôte [hóspede/hospedeiro], esse outro que se convida e que o personagem recusa ou repele, é

\footnotetext{
${ }^{18}$ Nos CCBBs, em 2014, o BB investiu R \$ 49.267.819,32 em programação, valores que incluem R \$ 46.710.149,17 via Lei Rouanet, e, sem incentivo fiscal: $\mathrm{R} \$ 383.917,30 \mathrm{em}$ projetos, $\mathrm{R} \$ 1.100 .628,53 \mathrm{em}$ ação promocional e $\mathrm{R} \$ 1.073 .124,32 \mathrm{em}$ contratos administrativos (transporte para visitantes e educativo, sistema de contagem de público). Os recursos destinados à manutenção dos quatro espaços foram da ordem de $\mathrm{R} \$ 69.536 .839,28$ que, somados aos relativos à programação, atingem o total de R\$118.804.658,60. (BANCO DO BRASIL, 2015a, p.121).
} 
uma parte dele mesmo. O estranho nunca foi tão familiar." (op.cit., p.860). O mesmo ocorre com os correlatos na língua inglesa

Em síntese, a substituição da designação hotelaria por hospitalidade não é decorativa nem com intenção de novidade e nem em razão de circunstâncias lingüísticas. Sabe-se que em inglês, não existe um termo correspondente à hotelaria, sendo utilizado "hospitality" e que pode ser traduzido como hospitalidade, ou seja, característica de um ser ou um lugar hospitaleiro. Essa terminologia (hospitalidade e não hotelaria) permite ampliar as possibilidades de campos científicos para o estudo de práticas sociais e administrativas que venham representar estilos de acolhimento de viajantes com desdobramentos para a convivência social. [...] (NEVES e ALEXANDRE, 2006, p.4)

Na língua portuguesa, os termos não são correlatos e cada um designa uma condição: o hospedeiro é o anfitrião, aquele que recebe, e o hóspede, quem é recebido. Ainda assim, “o mínimo deslize instaura o desconforto ou o inverso da hospitalidade, que é a hostilidade (não por acaso de mesma raiz etimológica)". (CAMARGO, 2011, p.17)

No evento denominado "Banco do Brasil Day", realizado nos dias 23 e 24 de novembro de 2009, o diretor de Estratégia e Organização, Marco Antônio Ascoli Mastroeni, apresentou "O processo de construção da estratégia no Banco do Brasil" no qual o destaque era a estratégia corporativa para o período de 2010-2014. Com o slogan “Todo Seu”, a Missão era a de:

Ser a solução em serviços e intermediação financeira, atender às expectativas de clientes e acionistas, fortalecer o compromisso entre os funcionários e a Empresa e contribuir para o desenvolvimento do País. (BANCO DO BRASIL, 2009)

Como Valores, destacava:

Ética e transparência; Compromisso com o desenvolvimento das comunidades e do País; Responsabilidade socioambiental; Excelência e especialização no relacionamento com o cliente; Gestão participativa, decisão colegiada e trabalho em equipe; Ascensão profissional baseada no mérito; Marca como diferencial competitivo; Conservadorismo e proatividade na gestão de riscos; e Comprometimento com rentabilidade, eficiência e inovação. (op.cit.)

Já a Visão de Futuro destacava:

Sermos o primeiro banco dos brasileiros no Brasil e no exterior, o melhor banco para trabalhar e referência em desempenho, negócios sustentáveis e responsabilidade socioambiental. (op.cit.) 
Quatro anos depois, no Relatório da Administração do Banco do Brasil relativo ao ano de 2014 (DIÁRIO OFICIAL DA UNIÃO, 2015), a instituição apresentou sua estratégia corporativa para o período de 2015-2019. A essentia estava orientada pelo conceito "Banco de mercado com espírito público" e se efetivava pela Crença de que "um mundo bom para todos exige espírito público em cada um de nós". Assim, tem a Missão de operar como "Banco de mercado com espírito público. Ser um banco competitivo e rentável, atuando com espírito público em cada uma de suas ações junto a toda a sociedade". Para tanto, mostra aonde quer seguir se desenvolvendo, com a Visão de Futuro que objetiva: "Ser o Banco mais relevante e confiável para a vida dos clientes, funcionários, acionistas e para o desenvolvimento do Brasil." É como a instituição se organiza e se enxerga para seguir se mantendo como uma das maiores do sistema financeiro no mundo. (op.cit.).

Apesar das diferenças observadas nos dois posicionamentos, o Banco mantém-se firme no propósito de ser líder de mercado e referência em segurança, tendo a marca como diferencial. Com essa premissa, é como se decretasse "minha ipseidade, minha soberania de hospedeiro" (DERRIDA, 2003, p.49).

O turismo é uma das atividades chave da modernização contemporânea que privilegia relações sociais típicas da sociedade de consumo ao transformar o lazer em mercadoria a ser consumida em viagens, pressupondo outros consumos. Faz-se necessário reconhecer que nesta sociedade a organização socioespacial é decorrente das imposições do modo de vida moderno que prioriza as necessidades do capital em processo contraditório que enfraquece o Estado, mas fortalece os movimentos sociais e a democracia [...]. (CORIOLANO, ARAÚJO e VASCONCELOS, 2009, p.13-14)

No entendimento de Coriolano et alli., o turismo está inserido, é parte da política econômica global, e, assim, seria ingenuidade não perceber que as ações para ele voltadas não estariam vinculadas aos princípios do mercado. O pensamento vai ao encontro da essência do controlador do CCBB, que se organiza no intuito de ser um "banco de mercado com espírito público".

As aprovações para instalação dos CCBBs Brasília e São Paulo possibilitaram ao Banco do Brasil, como lembra Vieira (2006), fazer-se presença em capitais que reforçariam o seu poder simbólico: o Rio de Janeiro, considerado, à época, a capital cultural do País, São Paulo, pela potencialidade econômica, e Brasília, pela sua importância política.

[...] A elegibilidade de Brasília fora mesmo uma surpresa, porquanto, até onde se apurou, não houve a demanda ou a pressão sistemática das autoridades e mídia locais para esse fim, o que parece confirmar os rumores 
de ter sido uma iniciativa da presidência ${ }^{19}$ sob a assessoria dos gestores da Diretoria de Marketing e Comunicação. Ou seja, a confluência de interesses internos (dos que viam na disseminação de centros culturais nichos de trabalho mais prazerosos ao espírito) aos interesses políticos externos, que insuflavam a apropriação da cultura como fonte de poder econômico e imagético, viabilizou de uma tacada só o surgimento dos dois novos CCBB. (VIEIRA, 2006, p.210-211)

Cabe ao pesquisador investigar as circunstâncias em que se origina e se delineia tal aproximação, bem como os contextos e processos em que esse espaço e essa relação se constroem, por meio de um discurso determinante na comunicação de um destino que deixa de se identificar com o sistema financeiro para imiscuir-se às práticas comunitárias sociais e culturais. Por meio da cultura, o BB, possuidor do faro do contemporâneo, se insere na práxis transformadora e modernizante da cidade. Como CCBB, a Empresa não só presta serviços, mas apresenta-se à sociedade como anfitrião de um espaço que tem se tornado, a cada ano, mais hospitaleiro.

\subsection{Cultura e identidade - esboços de interlocução}

Interpretar os discursos que versam sobre os conceitos de cultura e identidade no mundo contemporâneo apresenta-se como tarefa, no mínimo, desafiadora. São muitas e, por vezes, díspares as definições que um e outro recebem, a partir de classificações que servem, em princípio, ao cunho ideológico.

Destarte, este trabalho não entra no mérito das atividades culturais desenvolvidas pela programação. No entanto, pela natureza do objeto, a pesquisa orienta-se pelo tema da cultura, ainda que consciente de que se trata de questão polêmica e controversa, cuja discussão

[...] provavelmente nunca terminará, pois uma compreensão exata do conceito de cultura significa a compreensão da própria natureza humana, tema perene da incansável reflexão humana. [...] (LARAIA, 1986, p.63)

As questões relativas a cultura e identidade têm sido extensamente discutidas na teoria. Nesta era, ditada pela velocidade e pela essência da dúvida, a premissa é a de que as concepções formuladas até aqui são fonte de conhecimento e precisam ser rediscutidas constantemente. As mudanças nas conceituações de cultura, identidade e seus correlatos ${ }^{20}$ são

\footnotetext{
${ }^{19}$ Entre janeiro e julho de 1999, Andrea Sandro Calabi ocupou o cargo de presidente do Banco do Brasil, sendo substituído por Paolo Enrico Maria Zaghen, que ficou no posto entre julho de 1999 e março de 2001. O parecer de criação do CCBB Brasília data de 09 de fevereiro de 2000. (VIEIRA, 2006, p.211)

${ }^{20}$ Por "correlatos" entendem-se os papeis desenvolvidos pelos atores que compõem o quadro da cultura e da identidade, tais como: indivíduo, sociedade, meio, estado, nação.
} 
apenas parte de um amplo processo de deslocamento dos quadros referenciais promovidos pelas sociedades modernas.

É, portanto, de uma ideia de cultura e de identidade que vêm se modificando ao longo dos séculos o nosso foco. E suas ambiguidades refletem a ambivalência da construção de seus conceitos. O CCBB DF é descendente e protagonista desse processo. Cabe investigar como se dá a construção da identidade do Centro como lugar de visitação e acolhida.

\subsubsection{A Cultura em Questão}

A obsessão pelo universo ordenado vem do pensamento grego. Para os estudiosos de então, o oposto de Cosmos (ordem) era o Caos (desordem). Na sociedade hodierna, tudo é passível de questionamentos. E, assim, a desordem pode ser compreendida como base para o ordenamento (darwinismo).

Os poemas homéricos, sobretudo Odisseia, Teogonia, de Hesíodo, e a Bíblia, as principais fontes do imaginário ocidental, exaltam, em contrapartida à agressão humana, o antídoto da hospitalidade. Mais: mostram, o que é menos percebido, que se trata de um ritual do qual o hóspede também participa. [...] Assim, do ponto de vista das nossas principais fontes de inspiração, a hospitalidade remete ao divino. Não por acaso, antes do direito positivo, em diversas culturas, o templo religioso era aberto a todos e aquele porventura ameaçado gozava debaixo de uma imunidade cuja violação era equiparada a sacrilégio. (CAMARGO, 2011, p.16)

Essa "instalação do divino no seio do humano" (FOUCART, 2011, p.966) reforça a ideia de que a arte de receber integra e transforma as diversas culturas.

Ao longo dos séculos, o mundo e com ele as pessoas, as comunidades, vêm provocando e sofrendo mudanças. Ambos são, portanto, ativos e passivos da história. Uma das mais citadas e importantes ${ }^{21}$ definições de cultura consta na introdução de Burnett Tylor para seu livro Primitive Culture (1871):

Cultura ou civilização (...) é o todo complexo que inclui conhecimento, crença, arte, lei moral, costumes e quaisquer outras capacidades e hábitos adquiridos pelo homem como um membro da sociedade. (apud BURNS, 2002, p. 75).

Nessa conceituação, cultura tem a ver com valores adquiridos e transmitidos entre gerações, com padrões de comportamento e conhecimento. Ela, portanto, estabelece uma clara

\footnotetext{
${ }^{21}$ Importantes porque se subentende que o significado da cultura ultrapassa o âmbito da associação com a matéria, sendo relacionado à interação entre pessoas, à assimilação e ao acúmulo de conhecimentos que podem ser transmitidos de uma geração a outra.
} 
diferença entre o que pode ser herdado biologicamente e o que pode ser adquirido pela aprendizagem. No entanto, teóricos vêm defendendo que todas as culturas mudam, porque a sociedade possui uma dinâmica própria, que responde ao ambiente e, consequentemente, à tecnologia básica da vida moderna.

O que levaria uma instituição financeira a investir em um segmento que não é o seu, concentrando investimentos em espaços com equipamentos próprios, prevendo programação regular e diversificada, de modo a conquistar seu visitante? Haveria um público-alvo específico ou a meta é justamente sua heterogeneidade? Uma possível resposta pode estar no modelo desenvolvido pelo CCBB, o qual permite a formação de plateia, fator essencial para a promoção daquilo que o próprio Centro define e denomina como cultura - a arte em suas formas mais variadas.

[...] O objetivo de contemplar obras de arte não é aprender a reagir exatamente como reagiu determinado artista. É o seu método que deve nos inspirar, o que significa que seria bom descobrirmos o que nos agrada em particular num certo trecho da natureza, levarmos as nossas experiências a sério e sermos seletivos nos nossos entusiasmos, de modo que a natureza possa se tornar uma força mais duradoura e terapêutica na nossa imaginação. (BOTTON e ARMSTRONG, 2014, p.132)

Acolher o olhar do outro e indicar a ele a existência de outras miradas são modos hospitaleiros aos quais o CCBB se volta, por meio, por exemplo, do Programa Educativo. Nesse projeto, crianças, adolescentes, jovens e adultos são convidados a olhar as obras expostas com o auxílio da história e das curiosidades nelas contidas.

Sociedade e cultura se modificam e são modificadas em resposta ao comportamento das gerações, acredita Burns, que ainda assinala: "Não é coincidência que a palavra "cultura" tenha, em suas raízes latinas (pense em 'cultivo'), uma conexão com a terra.” (BURNS, 2002, p. 86).

Essa ideia de cultura como movimento, e não assertividade, assim como pensamentos e conceitos, é comungada por Bauman: “[...] É da natureza das ideias que elas nasçam como heresias perturbadoras e morram como ortodoxias aborrecidas. [...]" (BAUMAN, 2012, p. 10). Desse modo, na reedição, 30 anos depois, de seu livro "Ensaios sobre o conceito de cultura", ele não se furta a reexaminar suas próprias formulações em retrospectiva, relembrando os problemas com os quais se defrontou e remodelando premissas.

Se antes Bauman depreendia cultura como um fenômeno objetivo, e assim justificava sua tentativa de elucidar as contradições - por acreditar que as incoerências encontradas eram fruto de "falhas analíticas" e, portanto, "corrigíveis"-, décadas mais tarde ele se depara com a 
impossibilidade, não só de eliminar a ambivalência do discurso da cultura, como alerta o leitor para o fato de que tal paradoxo é inerente à própria ideia de cultura.

Nesse processo, o sociólogo polonês toma a história "como a causa da "condição humana', e não como o caso que a exemplifica" (op.cit., p. 15). Ao retomar a perspectiva histórica da cultura, o pesquisador o faz com o intuito de não se perder, e observa que não se pode separar cultura do social, visto não existirem mudanças de curta duração na sociedade. Nesse ponto, o polonês conversa com o alemão Elias (1990), em suas abordagens que tratam de cultura enquanto processo.

Ao trazer à análise o processo civilizador das sociedades, Elias mostra que nos acostumamos a imaginar que determinada forma ou maneira de contato é mais adequada porque expressa mais fielmente a natureza humana - e se opõe a essa ideia. Para ele, o que houve foi um "condicionamento" e um "adestramento" no âmbito das relações.

Ao apresentar o livro de Elias (1990, p. 10), Renato Janine Ribeiro vincula o "condicionamento" ao behaviorismo e o "adestramento" a Nietzsche e a Freud. Por condicionamento, entende-se um processo de aprendizagem e mudança comportamental por meio de mecanismos de estímulo-resposta, no qual o sujeito aprende ao fazer a associação entre um e outro. Por "adestramento", tome-se o processo de aprendizagem no qual o homem torna-se previsível e precavido para se relacionar com as relações de causa e efeito.

[...] A relação de hospitalidade põe em jogo não dois indivíduos, mas duas categorias de atores: membros permanentes fortemente organizados entre si e o hóspede, que deve se introduzir numa organização doméstica à qual hoje em dia ele é cada vez menos estranho, na medida em que a divisão do trabalho no seio mesmo do grupo doméstico tende, mesmo que debilmente, a se recompor e a se repartir mais uniformemente pelo conjunto de seus membros. Chamado não somente a participar das tarefas domésticas, mas a contribuir para a vida do coletivo, o hóspede deve assim, ao mesmo tempo, estar presente sem todavia se impor, se regular pelo ritmo da vida doméstica (em termos de horários, de abastecimento, de participação nos gastos, de serviços...) sem pesar sobre a vida de cada um nem sobre a do grupo.[...] (GOTMAN, 2011, p.104)

O frequentador do CCBB conhece as regras do espaço e as segue ou transgride, sabendo das condições de receptividade do anfitrião. O público de 1.476 .744 visitantes alcançado em 2014 foi uma conquista que levou mais de 14 anos - dois anos antes haviam comparecido ao espaço 1.215 .763 pessoas. Parte dessa aceitação, infere-se, deve-se à ampliação da divulgação com os chamados via internet e sua forte penetração nos lares, nas escolas, no dia-a-dia do cidadão. Em outras palavras, tendo em vista os números apresentados, percebe-se que os brasilienses reconhecem o Centro como seu e nele procuram estar como 
visitantes, apropriando-se das áreas externas e participando ativamente das ações de lazer e entretenimento oferecidas.

\subsubsection{Sistema de relações}

Por meio de ensaios pensados e redigidos em diferentes formas e direções, o antropólogo norte-americano Geertz procura chegar a um conceito de cultura que assegure sua importância ao invés de enfraquecê-lo. Todos os textos, assim, argumentam em prol de uma conceituação da transitoriedade da verdade. Enquanto os iluministas pensavam " $x$ " sobre algo, hoje pensa-se outra coisa. Ele critica o senso comum e pressupõe a existência de um processo de interpretação relacionado a múltiplas linguagens e realidades. Geertz acredita que fazer uma descrição densa não é tão simples. Não basta apenas descrever o que se vê; é preciso estabelecer a relação teórica com seu tema, interpretando e contextualizando o fato.

[...] A análise cultural é intrinsecamente incompleta e, o que é pior, quanto mais profunda, menos completa. É uma ciência estranha, cujas afirmativas mais marcantes são as que têm a base mais trêmula, na qual chegar a qualquer lugar com um assunto enfocado é intensificar a suspeita, a sua própria e a dos outros, de que você não o está encarando de maneira correta. [...] (GEERTZ, 1989, p. 39)

E, com isso, embora Geertz não conteste a força criadora da incipiente definição de Tylor, como cultura sendo o "todo mais complexo", defende que tal conceituação pode confundir muito mais do que esclarecer. O norte-americano também trabalha com perspectiva diferente da de Bauman, apesar de ambos serem contrários aos critérios universais e favoráveis às concepções de Claude Lévi-Strauss sobre a futilidade da concepção sistêmica da cultura.

No entanto, como defendem teóricos da teoria antropológica, é importante estudar o passado para compreender o presente. Todo fator que se observa tem seu processo histórico.

[...] Um dos traços mais marcantes da história da hospitalidade é sua funcionalização crescente, implicando especializações múltiplas, quer se trate do controle cada vez mais cerrado da população, da hospitalidade sob condições (múltiplas e contraditórias), das hospitalidades institucionais com a ameaça permanente de que o lugar de hospitalidade seja um não lugar, isto é, um lugar vazio, vacante, onde não se poderia habitar, quando muito sobreviver.[...] (MONTANDON, 2011a, p.33)

Assim como a cultura, a hospitalidade se insere num sistema de significações. Introduz-se, neste contexto, Raymond Williams, para quem a cultura está na totalidade do processo social, com o indivíduo em contínua sociedade com a sociedade. Utilizando-se 
essencialmente das artes, ele questiona: por que o movimento artístico radical do século XX perdeu sua postura antiburguesa, virou ideologia e foi integrado ao novo capitalismo internacional? É essa a pergunta de fundo dos seus ensaios reunidos. Ao longo dos textos, ele usa o termo "convergência" da língua, da realidade, para definir "cultura" - e nega a proposição de Frankfurt, justificando que esta pressupõe a superioridade da cultura dita da "elite" em relação às demais culturas.

Renato Ortiz (1986) lembra que cultura, para os frankfurtianos, "não significa práticas, hábitos ou modo de vida", é Kultur ao modo alemão, associado à "arte, filosofia, literatura e música". A cultura teria, assim, uma "dimensão de autonomia" e "caráter universal", "o mundo espiritual, que se integra ao mundo material" e "perde sua dimensão "transcendental" (alienante) que a colocava como uma resistência, uma barreira à expansão do processo de racionalização".

No CCBB DF, o termo cultura é identificado à arte em suas diferentes formas de expressão, tanto que a programação inclui projetos nas áreas de música, teatro, artes plásticas, cinema, dança, ideias e arte-educação. Nessa concepção, o lazer e o entretenimento superam qualquer outro conceito sobre tão controversa palavra, cultura. Ao mesmo tempo, não se pode simplesmente conjecturar que tal significado constitua redução do termo. Na literatura acadêmica, cada uma das áreas destacadas ganha dimensões ímpares por parte de pesquisadores, na tentativa justamente de encontrar parâmetros para tais fenômenos que, igualmente ao Turismo, revivem, renascem e se fortalecem em diferentes fases. Todavia, o pesquisador não pode se apegar a tão superficial descrição.

É preciso notar que essa natureza do objeto é contemporânea, inventada pela linguagem, que não se furta em questioná-la. Neste trabalho, não se busca a natureza em si do objeto cultura ou da hospitalidade do CCBB, mas seus ecos evidenciados pela linguagem que o Centro estabelece como sendo seu constituinte.

Inserido no circuito mundial dos centros/museus mais visitados do mundo, o CCBB DF reflete uma realidade que é nacional. Pesquisa realizada ao longo de 2014, no Brasil, registra a hospitalidade, com 97,2\% de aprovação, como a característica mais marcante para os turistas estrangeiros que visitaram o País naquele ano ${ }^{22}$. Assim, outra vertente que deve ser

\footnotetext{
22 Pesquisa divulgada pelo Ministério do Turismo, em 18 de novembro de 2015. O estudo foi feito em parceria com a Fundação Instituto de Pesquisas Econômicas (Fipe). Foram ouvidos 44.080 entrevistados, mais de 10 mil turistas, apenas durante a Copa do Mundo, em 15 aeroportos brasileiros e 10 fronteiras terrestres, que representam mais de $90 \%$ do fluxo terrestre internacional. Disponível em: http://www.turismo.gov.br/\%C3\%BAltimas-not\%C3\%ADcias/5695-lazer-\%C3\%A9a-principal-motiva\%C3\%A7\%C3\%A3o-do-estrangeiro-que-visita-o-brasil,-revela-estudo.html. Acesso em 07 de dezembro de 2015
} 
lembrada é o da cultura transplantada. É desse pressuposto que parte Lúcia Lippi Oliveira, em “Cultura é patrimônio", para explicitar sobre a cultura brasileira.

[...] Desdobra-se dessa interpretação a compreensão de que temos uma cultura mestiça ou híbrida. Mas, cabe perguntar, que cultura não é híbrida, que cultura é verdadeiramente autóctone? [...] (OLIVEIRA, 2008, p.8)

Em seu guia sobre cultura e patrimônio, ela não questiona essa premissa, aceita-a. E narra o caminho que a sociedade brasileira tem percorrido na formação de sua cultura singular, nem por isso linear.

Apresentado ao público brasiliense por meio de obras nacionais, o CCBB DF mantém em seu radar a brasilidade em sua programação. No Edital 2013/2014, o Eixo Curatorial previa que a programação deveria "estimular a reflexão e a experiência do público e o compromisso com a sustentabilidade e com a inclusão social", assim como valorizar "a memória e a diversidade da cultura brasileira" por meio de "temas relevantes da sociedade contemporânea" (BANCO DO BRASIL, 2012).

Na seleção seguinte, o Edital 2015/2016 versava:

A curadoria será norteada pelas seguintes premissas: a) nova produção cultural brasileira; b) valorização da memória cultural brasileira; c) significativa expressão artística nacional e internacional; d) possibilidade de ações multidisciplinares; e) ineditismo da proposta. (BANCO DO BRASIL, 2014a, p.8)

Nota-se a valorização da brasilidade no último édito. Dos cinco itens aos quais a curadoria deveria ter como princípios, na análise das propostas inscritas, pelo menos três remetiam ao reconhecimento da produção nacional. A afirmação já era evidente no preâmbulo do mesmo Edital:

O Centro Cultural Banco do Brasil orienta-se pela atuação como agente incentivador da cultura brasileira, oferecendo à sociedade significativas expressões artísticas, proporcionando experiências interativas e transformadoras, contribuindo para a formação e o desenvolvimento cultural da sociedade brasileira. (BANCO DO BRASIL, 2014a, p.1)

Daí, seja qual for a brasilidade que o Centro comunique ou pretenda comunicar, ela tem função estratégica. Ao reconhecer-se nos eventos, por meio de seu nacional, o sujeito sente-se integrado, recepcionado pelo que de mais familiar existe. 
A valorização do hóspede e de sua singularidade pelo anfitrião transformase, na estratégia mercadológica, em segmentação do público. Já que não é possível considerar cada hóspede como indivíduo, busca-se considerá-lo incluído em grupos [...]. (CAMARGO, 2011, p.21-22)

E, como ser social, o visitante, convidado ilustre, sem saber-se elemento principal dessa relação, aproxima-se daquele "espaço multidisciplinar" fadado a inserir a capital federal no circuito dos principais projetos culturais. Como lembram Yázigi et alii, o lazer organiza-se na reprodução de relações sociais.

A indústria do turismo sabe captar (além de produzir) o desejo transfor-
mando tudo que toca em espetáculo controlado, o que transforma o
indivíduo num ser reduzido à passividade e ao olhar. Reproduz um espaço e
tempo controlados, homogêneos, vigiados. Reproduz a reprogramação da
vida sob a alegação da fuga do cotidiano, revelando uma ilusão sob a
aparência de liberdade de escolha. Na realidade há uma contradição não
revelada visto que o lazer produz a mesma rotina massacrante, controlada e
vigiada do trabalho, sob diferentes formas em lugares diferentes. A indústria
turística reforça a hierarquia social produzindo espaços diferenciados
exclusivos fechados. A característica do espaço produzido é a do
homogêneo, altamente excludente, com ausência de identidade. O lugar é
apenas o que pode ser visto, fotografado e depois esquecido. (YÁZIGI,
CARLOS e CRUZ, 1996, p. 32)

O que se observa é que o CCBB DF é um lugar que está no inconsciente coletivo, incorporado à ideia de lazer do cidadão brasiliense, e tem como referência a arte em seu aspecto relacional com a cultura. Como espaço pluridisciplinar, não exclui sua identificação com o condicionamento e o adestramento do visitante. Afinal, ao mesmo tempo em que o anfitrião concede ao hóspede liberdade, esta é vigiada por um poder disciplinar e regulador.

[...] Na cena hospitaleira, aquele que recebe (o anfitrião) deve honrar seu visitante (hóspede), servir-lhe o que tem de melhor em sua casa, atender às suas necessidades de acolhimento, hospedagem, alimentação e entretenimento, convidando-o a desfrutar daquilo de que gostar ou necessitar ("faça de conta que está sua casa"), organizando o espaço destinado a esse encontro, mas, ao mesmo tempo, vigiando-o. Este, por sua vez, deve honrar seu anfitrião com palavras e presentes, ocupando apenas o espaço que lhe é reservado, fora do qual todo uso necessita de permissão, e aceitando todas as gentilezas que receber. (CAMARGO, 2011, p.17)

Por "gentilezas", no caso, leia-se "programação". É nesse sistema de relações, com a constante presença da alteridade que o poder do CCBB se estabelece. Na sociedade pósmoderna, demarcada pelos estudiosos como sendo o período vivenciado pelo homem a partir da segunda metade do século XX: 
Os novos tempos [...] são [...] marcados pela globalização do mercado e da informação, pela diminuição do poder do Estado nacional, pela aceleração do tempo histórico e de sua percepção, pela ausência de um modelo único do qual todos se aproximam gradativamente, por diferentes identidades, diferentes memórias, diferentes patrimônios e por uma cultura transnacional, com seus viajantes virtuais. (OLIVEIRA, 2008, p.187)

É preciso lembrar, porém, que a globalização não é um fenômeno hodierno. É, antes, um fenômeno ocidental e desigual, porque trata como iguais os desiguais. Assim, o visitante do CCBB não precisou ir à Itália para apreciar trabalhos de incomparáveis nomes da pintura, como Da Vinci, Raphael, Veronese, Ghirlandaio, Michelangello, Donatello, Bellini, Botticelli, dentre outos, pois teve acesso a eles na mostra "Mestres do Renascimento: obrasprimas italianas" (BANCO DO BRASIL, 2013d). Outro exemplo é a arte contemporânea da japonesa Yayoi Kusama, cuja retrospectiva, "Obsessão Infinita”, em 2014, foi vista por mais de dois milhões de pessoas nas américas do Sul e Central, das quais 471.730 registradas no CCBB Brasília (THE ART NEWSPAPER, 2015, p.3).

Como todo e qualquer fenômeno, a globalização é de caráter complexo, abrange desde a economia política às ideologias culturais e ainda desperta diferentes ponderações. De um modo geral, e mais simplista, apresenta-se relacionada à expansão econômica europeia, a partir das conquistas além-mar. Em tempos recentes, com as intervenções e o alcance global da economia, especialmente dos Estados Unidos da América, é confundida com "imperialismo", sendo uma de suas vertentes o "imperialismo cultural", pelo predomínio do cinema e das artes ocidentais.

Yúdice sustenta que o argumento do imperialismo cultural foi criticado, principalmente, por três motivos: por desconsiderar "a subordinação das minorias internas (...) quando questionam a agressão simbólica do poderio imperial"; pelas complicações geradas pelas diásporas e migrações, complicando "a unidade que se presumia existir na nação"; e pelo hibridismo cultural (YÚDICE, 2004, p. 51).

Ao ocupar-se do tema, Burns (2002, p. 147) apresenta alguns argumentos de estudiosos para estimular a reflexão sobre a globalização. O primeiro deles é de Anthony Giddens, em The Consequences of Modernity, para quem a globalização está relacionada às influências de uma localidade na outra, ainda que distantes entre si, em função das relações sociais existentes entre elas. O segundo, de Angie Hoogvelt, em Globalization and the Postcolonial World: the New Political Economy, apresenta a globalização como "um processo, não um estado final de coisas", sendo, portanto, um conceito difereciado daquele que comumente se instala, de que vivemos em um mundo sem grandes diferenças, devido ao 
consumismo e aos produtos globalizantes. Uma outra linha de pensamento, ou terceira argumentação, é a de R. Robertson, em Globalization: Social Theory and Global Culture, para quem a globalização poderia ser caracterizada como "compressão do mundo". Tal conceito aproxima-se da clássica definição de Marshall McLuhan de "aldeia global". Essa mesma inclinação aparece em Dunning e seu Globalization of Business: The Challenge of the 90s, para quem o planeta, como um todo, assume características comuns quando o "intercâmbio de pessoas, bens, produtos, ideias e culturas entre fronteiras" passa a ser norma e não exceção.

Burns, no entanto, pondera que a comunicação eletrônica e instantânea ainda não está ao alcance de todos - e mais, que ela segue sendo o grande "paradoxo da teoria da globalização" quando, mesmo com toda sua força e potência, a comunicação não amplia o “entendimento entre as nações" (BURNS, 2002, p. 148). Segundo o autor, apesar de o nome indicar o contrário, a globalização possui características elitistas, que acabam por excetuar os excluídos do acesso à tecnologia e ao poder.

\footnotetext{
Vamos voltar à etimologia do termo exclusão. É excluído aquele que é mantido fora. Fora de quê? Do espaço dos incluídos. [...] Os excluídos, em geral, ficam fora de certos circuitos, mas integrados a outros. Eles não estão fora da sociedade, mas bem dentro da sociedade. Se não estivessem no interior da sociedade, não seriam excluídos, estariam simplesmente em outro lugar. [...] (BESSONE, 2011, p.1096-1097)
}

Pela programação apresentada ao longo dos seus anos de existência e das apresentações realizadas pelas redes e mídias sociais, o CCBB, assim como Bessone, parece entender que todos são passíveis de serem tocados. E não concorda com Burns, à medida que o espaço utiliza esses meios para ampliar, incluir - e não excluir - visitantes.

Mas quem define o status do incluído e do excluído? Essa questão semântica está longe de ser resolvida e nestas páginas não terá sua discussão ampliada pela complexidade que tal categoria abarca. No entanto, ela é um traço importante a ser citado, posto que a proposta de pesquisa considera o lugar da fala. Magali Bessone recorre a Saül Karsz, para quem a exclusão seria um "conceito falso" aplicado a um "problema verdadeiro" (op.cit., p.1090).

[...] Ora, o primeiro problema que encontramos, quando procuramos definir a exclusão, é o da posição do locutor. Quem define a exclusão, o excluído ou o incluído, aquele que se encontra fora ou o que se encontra dentro? É fácil, num primeiro momento, supor que o status do excluído é plausivelmente imposto pelo incluído. A categoria de exclusão só adquire sentido em 
relação à de inclusão, de inserção, de integração. Preocupado com suas prerrogativas e seus privilégios, o incluído define alguns critérios de inclusão que justificam a sua integração ao sistema e as preferências e recompensas autorizadas por essa integração. [...] A exclusão confirma o ideal da inclusão, que funciona como uma marca de referência ou um modelo, e os incluídos fazem questão de informar que eles o são. [...] (BESSONE, 2011, p.1090)

No imaginário popular, a tendência ainda é a de se considerar cultura o que é encontrado em museus, monumentos, espetáculos. No entanto, o termo encerra, em si, uma gama infinita de significados que variam de acordo com o contexto. Ademais, cultura não é mero conhecimento, mas conhecimento qualitativo. É um saber que, além de ser informação, repercute sobre a sensibilidade, a imaginação, a moral, em suma, sobre todo o conjunto vital de uma pessoa, que vai desembocar na forma como ela recebe e é recebida nos espaços. Neste estudo, em especial, pelo CCBB Brasília.

Como nos lembra Williams, todos têm cultura porque a praticam. A práxis cultural cotidiana possibilita tanto a invenção de novos saberes quanto o esquecimento seletivo dos antigos. Porém, como argumenta Bauman, alguns se recusam a desaparecer muito depois de já terem perdido seu significado.

\subsubsection{Princípio de identidade na hospitalidade do Centro Cultural}

O campo das ciências humanas, ao longo do tempo e por diversas maneiras, tem procurado definir um tema tão controverso quanto identidade. A principal preocupação e ao mesmo tempo dificuldade encontrada tange justamente o caráter mutável do objeto de estudo.

Tomando-se por base o ponto de vista sociológico, toda e qualquer identidade é construída. Mas a assertiva para por aqui, pois questões se impõem: cada identidade é concebida e edificada a partir do quê, por quem, para quem e para o quê? Ao passar por todo esse processo, o indivíduo e os grupos sociais constroem a história, a memória coletiva e as relações de poder. Na visão de Castells:

No que diz respeito a atores sociais, entendo por identidade o processo de construção de significado com base em um atributo cultural, ou ainda um conjunto de atributos culturais inter-relacionados, o(s) qual(is) prevalece(m) sobre outras fontes de significado. Para um determinado indivíduo ou ainda um ator coletivo, pode haver identidades múltiplas. No entanto, essa pluralidade é fonte de tensão e contradição tanto na auto-representação quanto na ação social. [...] (CASTELLS, 1999, p. 22) 
O autor segue refletindo sobre a tensão representada por esse pluralismo, pois não se deve confundir identidade com os papeis que o indivíduo exerce na sociedade (pai, mãe, religioso, fumante, trabalhador): "Identidades constituem fontes de significado para os próprios atores, por eles originadas, e construídas por meio de um processo de individuação." (CASTELLS, 1999, p. 23)

A declaração de Castells conduz à reflexão de que há muitas configurações em uma única experiência. Em suas publicações, o CCBB preocupa-se não somente em divulgar a programação que realiza, mas também em incentivar o visitante a perceber a relação dele com a cidade.

A dádiva também institui uma relação assimétrica de poder. Como doador, o anfitrião domina a cena, e o hóspede deve a ele se submeter. Mas, na sucessão de dádivas e contradádivas, inclusive o convite para retribuir a visita, quando hóspede passa a anfitrião, o outro também deve a ele se submeter. [...] (CAMARGO, 2011, p.17)

O CCBB, então, recebe o visitante, cuja retribuição é a própria visita, pois receber, obter o maior público possível, é um dos objetivos do Centro. Assim, este convida com generosidade tal a ponto de o próprio visitante sentir-se à vontade para ser também anfitrião de outros visitantes.

\footnotetext{
Hospitalitas vem do substantivo hospitalis, ele mesmo derivado de hospes, "aquele que recebe o outro". É um gesto de acolhida e de hospedagem gratuita. Lembremos que, ao receber o hostis, o hospes o coloca no mesmo nível que o seu, dá-lhe uma parte de seu poder de "déspota". Na origem de toda essa família de palavras, um verbo: hostire, igualar. A noção é fundamental. A hospitalidade é gesto de compensação, de igualização, de proteção, num mundo em que o estrangeiro originalmente não tem lugar. Portanto, não pode haver gesto de hospitalidade, no sentido etimológico do termo, sem desigualdade de lugar e de status entre hospedeiro e hóspede: um está no interior, dono da casa, sedentário, é aquele que recebe; o outro vem do exterior, está de passagem, é recebido. O convite, a acolhida, a caridade, a solidariedade, parecem ser formas vizinhas e derivadas de uma forma inicial de hospitalidade. (GRASSI, 2011, p.45)
}

Essa igualdade de raiz etimológica indica, inclusive, um sentimento de pertencimento. Um (anfitrião) e outro (visitante) sabem desenvolver seus papeis, reconhecem suas identidades, ainda que na sociedade moderna esses variem a todo momento.

Hall (2004, p. 10-13), em seus estudos, avalia a existência de uma "crise de identidade" e suas consequências. Para tanto, inicia suas reflexões a partir de três diferentes concepções: "sujeito do Iluminismo", "sujeito sociológico", e "sujeito pós-moderno". O 
entendimento sobre o sujeito do Iluminismo traz à tona o ser dotado de razão, unificado, centralizado, com identidade fixa - e essencialmente masculino (à época, século XVIII, o discurso era de que as mulheres eram inferiores, tanto física quanto intelectualmente, devendo viver sob o jugo da autoridade masculina). É um indivíduo que sofreu influência direta de importantes movimentos culturais, religiosos e científicos como o Humanismo Renascentista, a Reforma Protestante e as revoluções científicas.

O entendimento de Hall para o sujeito sociológico floresce na medida em que o sujeito individual não sustenta as mudanças e passa a estar envolvido em processos de grupo. A identidade então é formada nessa “'interação” entre o eu e a sociedade”, ocupando o espaço entre o mundo pessoal e o mundo público. Trata-se, portanto, de uma relação dialética, de reciprocidade. Esse movimento dá origem ao sujeito pós-moderno, para o qual a identidade não se apresenta centralizada, única, fixa ou permanente, mas modifica-se constantemente. Esse conceito emerge do deslocamento das identidades do sujeito cartesiano, racional, situado no centro do conhecimento.

Muitas descobertas propiciaram o aparecimento e o fortalecimento desse sujeito cartesiano, como os escritos de Marx, nos quais a infraestrutura (meios de produção) sempre determina a superestrutura (estado e sociedade); a descoberta do inconsciente por Freud, para quem a identidade não é inata, sendo constantemente construída; as teorias do linguista Ferdinand de Saussure, cuja defesa assenta-se na afirmação de que a produção de significados não é uma construção individual; e o trabalho do filósofo e historiador Michel Foucault, com a idéia do poder disciplinar, composto pela regulação e pela vigilância das ações do indivíduo. Essas novas perspectivas auxiliam na compreensão da não-existência de uma unidade de identidade nem para um indivíduo nem para uma instituição, cuja natureza está sedimentada no vocábulo foucaultiano controle. E o CCBB não foge à regra: “A história da hospitalidade é marcada pelo desejo de controlar o hóspede.” (MONTANDON, 2011a, p.34).

[...] Claro, controlando-o, o que pode parecer negativo e repressivo, ele pode pretender do mesmo modo protegê-lo, tornar a comunicação possível, estender a informação e a transparência [...]. (DERRIDA, 2003, p.49 e 51)

Para Hall, o conceito de identidade passou daquele ligado ao sujeito do Iluminismo para o conceito sociológico e, depois, para o do sujeito pós-moderno:

[...] A identidade plenamente unificada, completa, segura e coerente é uma fantasia. Ao invés disso, à medida que os sistemas de significação e representação cultural se multiplicam, somos confrontados por uma 
multiplicidade desconcertante e cambiante de identidades possíveis, com cada uma das quais poderíamos nos identificar - ao menos temporariamente. (HALL, 2004, p. 13)

O sujeito reconhecido por uma identidade estável está se tornando fragmentado e composto por diversas identidades, algumas contraditórias ou não-resolvidas. Seria o caso do CCBB? Esse espaço multidisciplinar com a responsabilidade de ter uma programação regular durante seis dias por semana, na qual o visitante é tanto senhor do espaço quanto convidado?

[...] A dádiva da hospitalidade é reconhecimento e ênfase de uma original comunidade dos bens, de que aquilo que pertence a um pertence ao outro, que entre o teu e o meu, entre ti e mim, um comum pertencimento, um vínculo secreto vibra e canta. (MONTANDON, 2011a, p.35)

Como lembra Montandon, a "hospitalidade desapropria os limites da propriedade" (op.cit.). Essa antinomia incorpora a visão da moderna condição humana. O público retribui a acolhida, tornando-se presença no espaço e sendo, ao mesmo tempo, seu divulgador e cicerone para outros convivas.

Percebe-se que a interface entre estes dois fenômenos, cultura e identidade, combina fatores desafiadores, tais como informação (sabe-se da programação pelo site, pelas redes sociais, pela mídia), conhecimento (apreciação da obra de determinado artista), costume (ir a um espaço cultural como parte dos afazeres cotidianos). Ambos apresentam-se como corpos complexos, com diversas e distintas definições, percepções, bibliografias. Na literatura encontrada sobre cultura, identidade, globalização, modernidade, observa-se que:

[...] Os estudos constroem-se sobre outros estudos, não no sentido de que retomam onde outros deixaram, mas no sentido de que, melhor informados e melhor conceitualizados, eles mergulham mais profundamente nas mesmas coisas. [...] (GEERTZ, 1989, p. 35)

Há de se reconhecer, na pós-modernidade, que a compreensão do Turismo e da Hospitalidade passa pela necessidade de assimilar, perceber a condição humana em toda a sua complexidade.

[...] As práticas turísticas contribuem para a construção de novas subjetividades e de ressignificações sociais, novas leituras [...] sobre as diferenças (culturais, estéticas, patrimoniais, étnicas, raciais) [...] de reconhecimento de alteridades (o outro como Outro, íntegro em sua totalidade diferente da minha), de tolerância, de pluralidade de convivências. (SIQUEIRA, 2005, p.123-124) 
A sociedade é o espaço onde o indivíduo nasce, cresce e vive, gerando e transmitindo saberes. Mas o ser não se agrupa apenas para manutenção da espécie; uma premissa importante para tal é o fator proteção. Para Giddens (2002), o medo na sociedade prémoderna é diferente do medo na sociedade de risco (era industrial). $\mathrm{O}$ indivíduo nas relações pós-modernas está constantemente temeroso por não mais ter a segurança inicial do parentesco nem seus referenciais, pois os poderes globais permitem a derrubada de laços. As fronteiras, no entanto, são flexíveis.

[...] O hóspede é, por seu turno, visto sob seus múltiplos aspectos: o convidado de honra, o convidado de marca, o hóspede familiar, o exilado, o estrangeiro, o refugiado, o ocupante, o naturalizado. (CONSTANTINESCU, 2011, p.681)

No CCBB, eventos como o piquenique e a meditação da lua cheia são respostas do visitante ao chamado do espaço como lugar de convivência e contemplação - provas do valor simbólico do Turismo. Ambos são também exemplos de como o turista se torna anfitrião no espaço do outro.

Em tempos de um mundo globalizado, nem mesmo o conceito de sociedade está incólume da incerteza. Novas características espaço-temporais se apresentam para colocar em xeque sua definição clássica de sistema de ordenamento da vida social. Também "nações" não são, necessariamente, sinônimas de "sociedades" e, muito menos, mantêm sua tão propagada unicidade cultural e linguística. Como destaca Montandon na Introdução da quinta parte do essencial compêndio sobre a história da hospitalidade: “A utopia é um motor essencial para pensar a hospitalidade.” (MONTANDON, 2011b, p.996).

No pensamento do sociólogo Elias, a dita civilização está constantemente em processo. Essa perspectiva, porém, não é vista como progresso, mas como dinâmica social que se estabelece no seio das diversas sociedades. O autor também assinala que, nas sociedades desenvolvidas, o "eu" é mais valorizado que o "nós", ou seja, o coletivo. Nem por isso entende que as ciências sociais possam ou devam dicotomizar sociedade e indivíduo: “[...] vemos o quanto a existência da pessoa como ser individual é indissociável de sua existência como ser social” (ELIAS, 1994, p. 151).

Por identidade, entendo o processo pelo qual um ator social se reconhece e constrói significado principalmente com base em determinado atributo cultural ou conjunto de atributos, a ponto de excluir uma referência mais ampla a outras estruturas sociais. Afirmação de identidade não significa necessariamente incapacidade de relacionar-se com outras identidades (por exemplo, as mulheres ainda se relacionam com os homens), ou abarcar toda 
a sociedade sob essa identidade (por exemplo, o fundamentalismo religioso aspira converter todo mundo). Mas as relações sociais são definidas vis-à-vis as outras, com base nos atributos culturais que especificam a identidade. [...] (CASTELLS, 2013, p.57-58)

Vale salientar que as formas de relação do indivíduo com o mundo vêm se transformando nesses tempos de modernidade líquida, em que a civilidade humana vivencia transformações e na qual o tempo e o espaço deixam de ser concretos e absolutos para serem líquidos e relativos (BAUMAN, 2003). Com essa perspectiva, também não se deve criticar o fato de não existir almoço grátis nas relações sociais, como no gesto de hospitalidade. 


\section{CAPÍTULO 3 - ESPAÇO - ÂNIMA LOCAL}

"Não precisa pressa porque os lugares estão parados. Os lugares estão no lugar porque não precisa pressa."

Arnaldo Antunes

O crescente público frequentador do CCBB demonstra que o espaço vem atendendo as expectativas dos seus visitantes, pois, como lembra Neves, na sociedade contemporânea, com acesso à tecnologia da informação e aos diversos meios de comunicação, o indivíduo pode escolher livremente o que fazer para ocupar seu tempo livre (NEVES, 2009, p.3). E o Centro brasiliense tem sido essa opção para muitos.

Apesar da redundância, é preciso lembrar que Brasília, por si só, é uma cidade que atrai turistas do Brasil e do mundo a partir de diferentes motivações: seu status de capital federal, a curiosidade de ter sido construída em cinco anos, pelos monumentos e edifícios de Niemeyer ou mesmo pelo traçado urbanístico de Lúcio Costa. Inúmeros estudos dão conta da personalidade e das facetas da capital, aos quais não iremos nos ater.

A região turística corresponde a uma área com certa densidade de frequentação, serviços e equipamentos turísticos e com uma imagem que lhe caracteriza. Às vezes se confunde ou se identifica com um conjunto natural, em cujo interior se circunscreve, como nos núcleos urbanos ou focos de frequentação turística litorâneos, localizados em diversos municípios limítrofes e pertencentes a um mesmo conjunto geográfico. É possível distinguir pelo menos três tipos de regiões turísticas: a) os âmbitos espaciais considerados a priori, onde existem atividades turísticas suscetíveis de serem analisadas; b) as regiões homogêneas; e c) as unidades administrativas consideradas regiões turísticas. (YÁZIGI, 2001, p.33-34)

Centremos no CCBB DF e seus domínios - a caracterizá-lo como turístico, como na descrição de Yázigi. O projeto paisagístico de Alda Rabelo Cunha, com as árvores e um amplo jardim esverdeado, mantém destacado o conjunto arquitetônico de concreto concebido por Oscar Niemeyer. Tais estruturas ganham denominações e funções distintas das ciências. Espaço, paisagem, território e lugar são elementos caros para Milton Santos (1926-2001), para os quais o mestre dedicou boa parte de suas reflexões metodológicas.

Paisagem e espaço não são sinónimos. A paisagem é o conjunto de formas que, num dado momento, exprimem as heranças que representam as sucessivas relações localizadas entre homem e natureza. O espaço são essas formas mais a vida que as anima. (SANTOS, 2006, p.66)

O geógrafo prossegue: 
A palavra paisagem é frequentemente utilizada em vez da expressão configuração territorial. Esta é o conjunto de elementos naturais e artificiais que fisicamente caracterizam uma área. A rigor, a paisagem é apenas a porção da configuração territorial que é possível abarcar com a visão. Assim, quando se fala em paisagem, há, também, referência à configuração territorial e, em muitos idiomas, o uso das duas expressões é indiferente. (op. cit., p.67)

Em uma tentativa de utilizar tais noções no CCBB DF, tem-se todo o complexo (jardins, construções, a vista para o lago etc.) na composição de sua paisagem, a qual vem se modificando ao longo dos anos: o próprio edifício de concreto, os jardins e suas exposições permanentes - Casulo, de Darlan Rosa, e Améfrica, de Denise Milan -, suas inúmeras exibições temporárias - shows musicais, cinema ao ar livre etc. -, seus dois pavilhões de vidro, sua praça... São as formas que caracterizam a paisagem e configuram seu caráter histórico.

Já o espaço,

[...] uno e múltiplo, por suas diversas parcelas, e através do seu uso, é um conjunto de mercadorias, cujo valor individual é função do valor que a sociedade, em um dado momento, atribui a cada pedaço de matéria, isto é, cada fração da paisagem. (SANTOS, 2006, p.67)

Assim, tem-se como espaços os dois teatros, as três galerias, os dois pavilhões de vidro, cada qual com sua função, com seu uso e valores atribuídos. Logo, pode-se dizer que “paisagem e espaço são um par dialético" (SANTOS, 2008, p.79). E nessa relação:

O espaço é o resultado da soma e da síntese, sempre refeita, da paisagem com a sociedade através da espacialidade. A paisagem tem permanência e a espacialidade é um momento. A paisagem é coisa, a espacialização é funcional e o espaço é estrutural. [...] (op.cit., 2008, p.80).

O turista/visitante do CCBB DF se organiza e se (re)organiza nos espaços que, cada vez mais, tornam-se significativos para ele no momento em que pode tanto usufruir da programação oferecida quanto criar sua própria inserção, seu próprio estar no espaço, ou seja, apropriar-se dele. Como exemplo dessa adequação, o público ocupou o CCBB para venerar a natureza nas meditações da lua cheia, sendo a beleza da vegetação e a vista para o lago provas materiais dessa percepção pública, sem que houvesse para tal chamamento por parte do Centro. Também o piquenique, que reúne família, amigos, foi um ato espontâneo de ocupação pelo visitante. Na visão do público, tudo deve ser aproveitado, principalmente a paisagem. Nas palavras de Yázigi (2001, p.34), “nesse sentido, é preciso reconhecer uma multiplicidade 
de formas e tempos presentes na paisagem. [...]". E, assim, de maneira planejada ou lhana, natural, como anfitrião, o CCBB DF adapta-se para fornecer tanto conteúdo às formas de seu ambiente quanto infraestrutura aos seus frequentadores.

Para Santos, o espaço não pode ser estudado sem se observar também o homem e as instituições que o rodeiam. Daí serem as indagações sobre "a alma do lugar” (YÁZIGI, 2001) imprescindíveis para auxiliar a investigação a identificar como se dá o reconhecimento do CCBB como lugar de visitação e acolhimento. Eis uma das premissas deste estudo, que, ainda que esbarre na lógica econômica, tendo em vista o escopo e a origem dos recursos de seu principal mecenas, abre a possibilidade de se tratar o discurso do CCBB DF no que tange à necessidade de se desenvolver uma programação cultural eficaz, ao intuito de reforçar seu papel junto à sociedade local, de apresentar-se como espaço de encontro, de probabilidade de reorganização de laços de sociabilidade e de reafirmação de poder (FOUCAULT, 2013).

Todas as relações de poder funcionam, quer abrindo novos caminhos (modo abertura-de-novos-caminhos), quer fixando fronteiras (modo fixação-defronteiras), mas não funcionam sempre nos dois regimes em simultâneo ou com a mesma intensidade relativa [...] (SANTOS, 2011, p.268).

No seu percurso crítico, Boaventura Santos dialoga com Michel Foucault, de quem reconhece a contribuição para a compreensão do poder nas sociedades contemporâneas, ao mesmo tempo em que não se furta a exprobrar sua concepção: "Se o poder está em todo o lado, não está em lado algum" (op.cit., p.265). E conceitua poder como "qualquer relação social regulada por uma troca desigual" (op.cit., p.266), sabendo da dificuldade de se medir tal desigualdade, tendo em vista que "as relações de poder não ocorrem isoladas, mas em cadeias, em sequências ou em constelações" (op.cit., p.267).

O turismo recheado de alto valor simbólico conjuga o atributo e o atribuído; portanto, é também um processo humano que necessita de ressignificações às relações impostas pelos códigos capitalistas, que determinam não só o valor venal das mercadorias, mas também os valores impostos, como bens culturais e estilos de vida.[...] (GASTAL e MOESCH, 2007, p.12-13)

O número de visitantes que o CCBB apresenta indica que ir ao local tornou-se um hábito do brasiliense. E como lembra Botton et al (2014, p.59), "o hábito é o mecanismo pelo qual o comportamento se torna automático em várias áreas do nosso funcionamento.” E aí encontra-se uma diferença da condição humana: a capacidade de escolher, de decidir ir para e vir de um lugar para outro. Em 2014, quase 1,5 milhão de pessoas decidiram utilizar seu tempo livre no CCBB. 
Reconheço o lugar como uma arrumação que produz o singular, mas estimo que de modo algum se poderá entendê-lo ou trabalhá-lo sem a consideração da extensão de seus sistemas. Ele tem uma personalidade sim, mas não é sujeito. (YÁZIGI, 2001, p. 38)

Yázigi ressalta a responsabilidade do turismo e, com ele, de seus atores, para com o patrimônio local, o qual não deve se perder em meio às mudanças promovidas pelo cotidiano. A cultura de espetáculos que o visitante acompanha no CCBB torna este um lugar de cultura, um lugar que pode conter a dimensão espacial do cotidiano revisitado. Assim,

Cada lugar é, à sua maneira, o mundo. [...] Mas, também, cada lugar, irrecusavelmente imerso numa comunhão com o mundo, torna-se exponencialmente diferente dos demais. A uma maior globalidade, corresponde uma maior individualidade. [...] (SANTOS, 2006, p.213)

$\mathrm{O}$ visitante tem à sua disposição diversos canais de comunicação abertos para críticas e sugestões ao CCBB, tais como filipetas na bilheteria, e-mail, as redes sociais (Twitter e Facebook) pelos quais o público se manifesta. As respostas são obtidas pelos mesmos canais online ou por outros indicados pelo visitador, no caso dos comentários deixados nas urnas depositadas ao lado da bilheteria. Outra forma de participação é a apropriação do espaço - por exemplo, ao levar seus próprios apetrechos para preparar um piquenique ou adotar um dos bancos espalhados pelos jardins para leitura ao ar livre. O protagonismo do visitante, no CCBB DF, não ocorre apenas por meio dos eventos que o Centro conduz, partindo também de ações espontâneas de seus frequentadores. Trata-se da ocupação do espaço pelo cidadão, ao ponto de fazer daquele um lugar "todo seu" - como dizia a assinatura da campanha publicitária lançada no final de $2006^{23}$-, onde pode realizar um convescote, divertir-se, tomar um café, enfim, exercer seu amplo direito de cidadania.

Ser cidadão não é só fugir da pobreza do campo e se abrigar na miserável periferia das inchadas e violentas metrópoles brasileiras de hoje em dia. Ser cidadão é, principalmente, ter direito a uma vida decente, com um padrão de dignidade aceitável e acesso, não apenas ao essencial para sobreviver, mas também aos direitos elementares de produzir, consumir e se expressar com liberdade. A cidadania de primeira classe é a exigência inicial que todo brasileiro, sem distinção de credo, raça ou classe social, precisa fazer para se considerar perfeitamente integrado ao mundo livre e civilizado, que está sendo construído neste século XX. (MESQUITA, 1992, p. XII)

\footnotetext{
${ }^{23}$ Mais informações podem ser encontradas em: http://mundodasmarcas.blogspot.com.br/2007/05/banco-do-brasil-o-tempotodo-com-voc.html e http://www.bb.com.br/docs/pub/inst/dwn/Trocadefachadas.pdf - acessados em 30 de dezembro de 2015.
} 
Ao assenhorar-se de um espaço em que se conhecem os limites de ocupação, o cidadão confere autenticidade a um fenômeno em constante mutação. Isso porque o turismo obedece a uma lógica cuja premissa é o imaginário, o espaço "ressignificado" da e na esfera pública. Trata-se do "estranhamento" com o próprio olhar, despertando desejos e comportamentos ao deslocar-se, ou seja, ao "sair das rotinas espaciais e temporais" (GASTAL e MOESCH, 2007, p. 38) às quais o cidadão está habituado.

Cabe retomar Hannah Arendt e suas reflexões, no que tange à esfera pública, para a qual relaciona duas acepções. Na primeira, público seria tudo o que "pode ser visto e ouvido por todos e tem a maior divulgação possível" (ARENDT, 2007, p.59). Nesse conceito, observa-se que o CCBB DF preocupa-se com a difusão de si mesmo como ambiente ao qual o visitante não só é bem-vindo como também é partícipe das atividades. É o lugar próprio da experiência individual e, ao mesmo tempo, coletiva, contagiante, realizada a partir da percepção que se tem da realidade, daquilo que se experimenta. Na segunda definição, a filósofa tem como público o que é "comum a todos nós e diferente do lugar que nos cabe dentro dele" (op.cit., p.62). Estabelecendo-se a construção do Centro Cultural para todos, a partir de uma programação que satisfaça o maior número de pessoas, não importando classes sociais, estilos, seu principal mecenas procura encontrar vínculos que possam conduzir as pessoas àquele lugar, fazendo com que dele se apropriem, como espaço público, ainda que sabendo-o privado.

[...] Em poucas palavras, o lugar só existe com a reunião (e organização) de vários aspectos. Mas dada a efemeridade destas construções (memória coletiva, modismos da arquitetura e do urbanismo, a atual prevalência do individualismo no gosto etc.), a geografia física poderia ser o fator mais estável na definição da essência do lugar, o vetor de mediação de certas categorias construtivas. Já sabemos que o espaço é constantemente modificado pela história.[...] (YÁZIGI, 2001, p. 40)

As ampliações sofridas pelo CCBB ao longo dos anos são exemplo do que diz Yázigi. E é em uma constante mutação que o Centro concentra sua força e liderança. O frequentador (brasiliense ou não) é partícipe dessa organização ao contribuir para que a cidade (lugar de sua residência ou não), a capital federal, tenha um dos 100 centros culturais/museus mais visitados do mundo, desde a primeira publicação, em 2012, da listagem coordenada pela The Art Newspaper.

Como assevera Angelo Serpa, é especialmente "a história pessoal do indivíduo" que decreta a relação dele com seus espaços habituais: “[...] O lugar se transforma e vira história 
pessoal, permuta-se em sujeito.” (SERPA, 2014, p.133). É como se o CCBB, com sua programação e ambiente, deixasse de ser um castelo intangível.

Ao tratar, em seu artigo, sobre a dualidade acolhida e hostilidade do castelo, Pascale Auraix-Jonchière frisa que esse espaço no qual o turista sente-se seguro e protegido acaba por revelar processos que excedem a alçada da sociabilidade:

[..] Os princípios de uma hospitalidade entendida como prática social se interiorizam, se psicologizam. [...] Protegido pelo espanto que suscita tanto quanto por sua arquitetura eminentemente defensiva e pela geografia hostil que o circula, ele só pode ser o teatro de um estranho simulacro de hospitalidade, encenação de uma fatídica confrontação do eu consigo mesmo. [...] Objeto de uma transferência simbólica, a hospitalidade figura aqui uma etapa maior na progressão iniciática do personagem, que é também processo de individuação. Desviada de suas funções primeiras, ela é parte integrante de um caminhar interior no seio de um edifício psíquico. (AURAIX-JONCHIÈRE, 2011, p.477)

E como a pesquisa aborda um centro cultural, intrinsecamente identificado pela arte, essa relação de autoconhecimento do visitante passa, necessariamente, por ela. "Toda obra de arte vem imbuída de certa atmosfera moral e psicológica." (BOTTON e ARMSTRONG, 2014, p.34)

A arte, no CCBB, seria, nesse sentido, também um "lugar".

As famosas linhas curvas de Niemeyer, num projeto leve e funcional, aliamse à paisagem aberta do Planalto para criar um ambiente agradável, perfeito para apreciação de manifestações culturais. (BANCO DO BRASIL, s/d)

A professora Zeny Rosendhal (2007) recorre ao geógrafo W. Norton em seu “Cultural geography: themes, concepts, analyses" para afirmar que a "criação de lugares é um ato social e, portanto, os lugares diferem porque as pessoas assim os construíram”. Nessa acepção de lugar como "fenômeno inter-relativo", ou seja, que pressupõe a comunicação entre os seres

[...] os lugares fornecem modelos de sentido de pertencimento nas conexões que abordam as relações entre o social e o individual. Em outros termos, as pessoas se interpretam e são interpretadas de acordo com o lugar onde moram, ao qual pertencem, ou de onde se originam. (Norton, 2000, p.263 apud ROSENDHAL, 2007, p.246)

Parafraseando Rosendhal, que apresenta "o peregrino como consumidor do sagrado no santuário porque o seu comportamento revela a prática de atividades religiosas como a de assistir missa e receber os sacramentos..." (ROSENDAHL, 2007, p. 253), observa-se o turista 
como consumidor da cultura artística no $\mathrm{CCBB}$, devido ao seu comportamento revelar a prática de atividades próprias ao espaço, como a de exibir mostras expositivas, espetáculos, shows musicais e filmes - atividades que são diretamente dependentes do trabalho especializado dos profissionais das artes. Acrescenta-se a questão relativa à ritualização que permeia todo esse cenário, com horários marcados, assentos delimitados, modo de comportamento nas salas etc. - um ritual de hospitalidade.

A noção de hospitalidade encenada em contraponto a uma hospitalidade dita
genuína é mais complexa do que parece à primeira vista. Esse ritual
elaborado com base em outro ritual não acontece apenas na hospitalidade
comercial. Na verdade, a hospitalidade é sempre um ritual, sendo, pois,
natural a dificuldade frequente de distinguir a genuína da encenada. Mesmo
na hospitalidade doméstica, as recepções (jantares, festas) não apenas
limitam os anfitriões ao papel correspondente aos dos maittres de
restaurantes, como cada vez mais lançam mão de espaços e serviços
comerciais. [...] (CAMARGO, 2011, p.23) O ritual, esse conjunto de formalidades e pleno de valor simbólico, é praticado pelo $\mathrm{CCBB}$, desde o convite ao frequentador, no mundo virtual, com o discurso proferido por meio da rede de computadores. A forma de receber, a liberdade dada no ambiente, os serviços oferecidos... Tudo é criado e organizado para seduzir o visitante, personagem central no turismo, como atesta a reflexão de Yázigi:

Mas o que são os lugares sem pessoas? Hoje impossível de imaginar, senão em contextos intergalácticos. Toma forma, então, tudo aquilo que se falou sobre a noção de espaço-palimpsesto, de tecnologia, de história enfim. A paisagem tem atributos expressamente simbólicos. O homem e suas construções - a arquitetura, quer se queira ou não, fica sendo o grande marco da paisagem. Sem negar, é claro, as desconstruções, as cicatrizes... Num mundo globalizado, a personalidade do lugar encerra múltiplas identidades, produto dos movimentos de migrantes, fluxos de objetos e informações que, praticamente, puseram um ponto final a quase todas as comunidades isoladas da terra. Como se reencontrar neste cipoal que o mundo moderno tende nivelar? É assim que o trabalho, por ser estrutural do cotidiano das pessoas, e por muitas vezes manifestar-se visivelmente no espaço geográfico, convertese numa marcante forma de identidade. É assim também que o próprio turismo, como prática social e econômica, também é identidade, dependendo da intensidade e forma como se organiza, no contexto em que está inserido. (YÁZIGI, 2001, p. 35-36)

E, assim, o estudo investiga como, por meio do discurso, o Banco do Brasil constrói uma narrativa em que o CCBB Brasília torna-se um lugar em que é possível experienciar a prática turística da acolhida. Anne Dufourmantelle, no convite que faz a Derrida para falar da hospitalidade, evoca a busca pela aproximação "de um silêncio em torno do qual o discurso se 
ordena [...] mas que sempre, no próprio movimento da palavra ou da escrita, esquiva-se ao desvendamento.” (DERRIDA, 2003, p.4)

Quando entramos num lugar desconhecido, a emoção sentida é quase sempre a de uma indefinível inquietude. Depois começa o lento trabalho de familiarização com o desconhecido, e pouco a pouco o mal-estar se interrompe. Uma nova familiaridade se segue ao susto provocado em nós pela irrupção de "um outro" [...]. (op.cit., p.28)

Numa sociedade fascinada por aparências, o CCBB age de modo a tornar-se um lugar para o qual todos são bem-vindos, numa tentativa de manter sua imagem hospitaleira. No entanto, cada ação gera uma reação que pode implicar em agradar a alguns e desagradar a outros. Nessa perspectiva, qual seria o papel da linguagem utilizada no site e no Facebook do CCBB no chamamento a esse público visitante? E como as relações de poder e as relações sociais seriam construídas nesses espaços de comunicação? O discurso proferido estabelece o posicionamento da marca $\mathrm{BB}$, tendo a cultura como processo de formação e inclusão social (acolhimento). 


\section{CAPÍTULO 4 - MECÂNICA DAS REDES}

"Só permito a mim existir, hoje, enquanto consistência de palavras."

Silviano Santiago

Geertz é enfático ao defender que o conceito de cultura com o qual trabalha está relacionado a semiótica e, tal qual Max Weber, acredita que "o homem é um animal amarrado a teias de significados que ele mesmo teceu" (GEERTZ, 1989, p. 15). A cultura seria justamente esse emaranhado e seu exame.

Cabe inserir neste estudo outro espaço, o virtual, ânima da sociedade contemporânea. É nele que se encontram alguns dos principais canais de acesso público às informações veiculadas pela instituição e no qual se pode observar o discurso hospitaleiro do Banco para o CCBB enquanto destino turístico.

Trata-se de um campo de "novas tecnologias intelectuais" (LÉVY, 1993, p.9), "novas maneiras de pensar e de conviver" (op.cit, p.7), cujo papel na sociedade contemporânea cresce a cada dia, posto que mais e mais pessoas e instituições utilizam desses espaços discursivos para agir e interagir com seu interlocutor ${ }^{24}$. Nesse universo, os símbolos são referenciais e determinantes; logo, dotados de poder onipresente e invisível. Como tal, são instrumentos de conhecimento, comunicação e dominação, ainda que percebidos de forma doxológica, como mobilizador e não-impositivo (BOURDIEU, 1989).

A programação do Centro é divulgada por meio de livreto impresso mensalmente, com tiragem de 10 mil exemplares ${ }^{25}$, disponível gratuitamente no próprio espaço. A publicação contém as atividades oferecidas ao longo do mês, com o resumo do(s) espetáculo(s), da(s) mostra(s) de cinema, da(s) exposição(ões), do(s) debate(s) a ser(em) realizados. A mesma versão, porém no formato digital $(p d f)$, pode ser enviada por e-mail a todo e qualquer cidadão. O serviço, no entanto, depende da manifestação do destinatário, que deve solicitá-lo no site, mediante preenchimento de um cadastro. Observa-se, assim, que os dois meios divulgam as atividades oferecidas, mas de forma bastante restrita. O primeiro, porque reclama a presença do visitante e o segundo, pela necessidade de manifestação expressa do interessado.

O formato em $p d f$ também está disponível nos demais canais de divulgação do Centro, dentro da rede de computadores. E é assim, pelo meio digital, que a instituição atinge maior

\footnotetext{
${ }^{24}$ A título de exemplo, no Brasil, o Facebook é acessado diariamente por cerca de 59 milhões de usuários e mensalmente por 89 milhões, ou seja, oito de cada dez internautas, pois o número total no país chega a 107,7 milhões, segundo a consultoria eMarketer. Os dados são referentes ao segundo trimestre de 2014. Se comparada com 2013, a base de pessoas ativas na rede aumentou 105\%, atingindo 41 milhões de pessoas. (MEIO E MENSAGEM, 2014)

${ }^{25}$ Dados de maio de 2014.
} 
contingente de público eventual, por meio de suas páginas na internet, posto democrático e de acesso facilitado no mundo atual. É no discurso da construção do CCBB como espaço de hospitalidade para a vivência da experiência turística contido nessa presença virtual do CCBB Brasília que este estudo vem se estruturando. E isso em torno de plataformas sociais e institucionais, a saber: Facebook (relacionamento com o público que possui afinidade com atividades culturais cujo endereço é o /ccbb.brasilia) e site (www.bb.com.br/cultura).

O Centro atua ainda em outras plataformas de divulgação: Twitter, com pílulas de conteúdos sobre o universo do CCBB: programação, curiosidades, dicas culturais, datas comemorativas etc., podendo ser acessado por meio de @ ccbb_df; Instagram, rede com maior afinidade visual, por meio da qual o perfil do CCBB divulga imagens inspiradoras dos eventos, das exposições, dos bastidores e até da interação com o público - /ccbbbrasilia; Foursquare, organização de localização do CCBB, com dicas e ações de relacionamento com o público; e Youtube, repositório de vídeos referentes ao CCBB.

Para o desenvolvimento deste estudo do acolhimento por meio do discurso, optamos por direcionar nossa atenção no âmbito das plataformas Facebook e site, por entender serem essas as mais representativas da atualidade, tendo em vista a flexibilidade da linguagem, bem como a possibilidade de ampliação do público a ser atingido, em função da rede de computadores. Embora pudéssemos ter delimitado ainda mais o corpus, limitando a análise a apenas um dos canais, revela-se pertinente e mais produtivo o diálogo com as duas bases.

Fundamentado em Ribeiro (2007), é possível afirmar que a tecnologia é parte de um momento histórico e de constituição social, em um contexto de sociedade globalizada com foco na informação.

A ubiqüidade é apresentada como característica particular da hospitalidade
virtual, pois se refere à condição superior de estar em toda parte ao mesmo
tempo. A onipresença do emissor e do receptor da mensagem eletrônica
delimita suas inter-relações de anfitrião e visitante simultaneamente. As
pessoas chegam e partem virtualmente. Este mercado se torna virtual na
medida que (sic) se constitui uma relação especializada entre dois
protagonistas, aquele que recebe e aquele que é recebido e que, quase nunca,
estão no mesmo local ao mesmo tempo. Esta capacidade de estar em vários
lugares ao mesmo tempo, característica da comunicação virtual, é conhecida
como ubiqüidade. (NEVES e ALEXANDRE, 2006, p.6)

Esse fenômeno relaciona-se a mudanças no próprio perfil do anfitrião e das relações que estabelece com os turistas e o meio ambiente. "A aceitação desta simples definição muda nossas atitudes e nosso comportamento, pois a comunicação não é concordância, mas, sim, compreensão." (op.cit., p.7) 
Tal relação é construída por meio de signos. A padronização da programação do CCBB DF, com uma grade constante nas áreas de artes cênicas, artes visuais, cinema e música, com funcionamento de quarta a segunda-feira é um deles. O espaço está sempre preparado para atender o público em qualquer desses dias. O visitante assíduo sabe que encontrará ali, diariamente, o que ver, o que fazer, o que saborear, o que experimentar.

Castells lembra o interessante debate entre Roe Merrit Smith e Leo Marx em "Does technology drive History? The dilema of technological determinism”, de 1994, ao afirmar que: "A tecnologia não determina a sociedade: incorpora-a. Mas a sociedade também não determina a inovação tecnológica: utiliza-a." (CASTELLS, 2013, p.62). Logo, o resultado depende de um complexo processo dialético e interativo. Assim, à medida que conquista seguidores no mundo virtual, o Centro torna-se conhecido por um número maior de pessoas, possíveis visitantes, clientes em potencial daquele que sustenta a instituição cultural, os quais, por sua vez, têm a possibilidade de desfrutar de um ambiente acolhedor, com programação diversificada e de qualidade sob os mais amplos aspectos (posto que não cabem classificar nem mesmo julgar artistas e obras expostos) e a preços acessíveis, quando não é gratuita (como historicamente é a dedicada às artes visuais, ao programa educativo e aos projetos de ideias).

Por outro lado, Silverman (2009, p.165) afirma que "é lugar-comum declarar que a comunicação está sendo cada vez mais mediada pela tecnologia da informação". Tal assertiva pode ser notada pela velocidade da evolução da tecnologia, em especial a internet.

A rede digital tem crescido em uma velocidade espantosa; basta comparar seu crescimento com o de outros veículos de comunicação: o rádio levou 38 anos para atingir uma audiência de 50 milhões de pessoas; a TV aberta, 16 anos; a TV a cabo, 10; a Web apenas 5 anos. (XAVIER e SANTOS, 2005, p.30)

As descobertas e as facilidades da rede para o visitante ainda estão sendo realizadas. A inovação tecnológica vem se aperfeiçoando pela prática, com usuários aprendendo também por meio da ação, promovendo uma reconfiguração de redes de novas descobertas muito mais rápidas que o desenvolvimento tecnológico do passado.

O que caracteriza a atual revolução tecnológica não é a centralidade de conhecimentos e informação, mas a aplicação desses conhecimentos e dessa informação para a geração de conhecimentos e de dispositivos de processamento/comunicação da informação, em um ciclo de realimentação cumulativo entre a inovação e seu uso. [...] As novas tecnologias da 
informação não são simplesmente ferramentas a serem aplicadas, mas processos a serem desenvolvidos. [...] (CASTELLS, 2013, p.69)

Para comunicar seus produtos, bem como a programação dos CCBBs, por meio do site e do Facebook, o BB contrata uma empresa especializada. A coordenação das informações publicadas, porém, fica a cargo de funcionário concursado do BB.

Assim como a programação é escolhida por meio de edital público, a agência o é por meio de licitação. Em 2012, doze agências do País participaram de uma concorrência acirrada, na qual não faltou polêmica na disputa pela verba de $\mathrm{R}$ \$ 66 milhões por três anos de contrato. (TURLÃO, 2012). Ao final do processo, saiu vencedora a AgênciaClick Isobar.

"O Banco do Brasil, por sua importância e pelo porte, é uma conquista que
nos traz enorme orgulho. O resultado desse rigoroso processo de
concorrência posiciona de forma incontestável a AgênciaClick como a
melhor e maior agência do Brasil voltada às plataformas digitais", afirma
Abel Reis, presidente da AgênciaClick Isobar. O Banco do Brasil está
presente em 5.378 municípios e mantém 5.263 agências e 43.602 terminais
próprios de autoatendimento. (PROPMARK, 2012)

O vencedor da conta tinha a responsabilidade de "cuidar de toda a estratégia do BB nas plataformas digitais: planejamento estratégico, criação e desenvolvimento da comunicação da companhia" (op.cit.). O site ainda informa que aquela teria sido "a primeira concorrência realizada pela instituição a fim de segmentar seus investimentos em publicidade digital" (op.cit.). O Propmark, especializado na área de propaganda e marketing, resume todo o trabalho em "publicidade" quando o que está intrinsecamente envolvido no projeto ultrapassa a promoção.

O modelo de relacionamento digital tem sido uma das principais ferramentas para o Banco do Brasil fidelizar seus clientes. Dentre as inovações estão a certificação digital, com o objetivo de atestar a identidade do titular (pessoa ou organização) no mundo virtual, e o Mobile Banking, com diversos aplicativos para Smartphones. No entanto, os CCBBs ainda caminham a passos lentos quando o assunto é tecnologia. Para se ter uma ideia, somente em 2015, os CCBBs São Paulo e Rio de Janeiro começaram a agendar visitas pela internet, com o objetivo de diminuir as enormes filas que tomam conta dos respectivos centros, especialmente quando ali estão expostas obras de destaque internacional. Os CCBBs BH e Brasília ainda não adotaram tal medida. Apenas para pontuar, todos os centros mantêm agendamentos por telefone - que não deixa de ser um exemplo de tecnologia - para visitas guiadas de alunos de escolas a toda e qualquer exposição, com o CCBB disponibilizando ônibus gratuitamente para os frequentadores de escolas públicas. 


\subsection{Processo evolutivo da comunicação}

Tanto o termo rede social como mídia social já existiam antes do advento da internet, mas nenhum deles foi tão usado quanto nos tempos atuais. E, por serem ambos antigos, vêm sofrendo adaptações e variações de conceitos para o ambiente web. Há teorias que defendem que ambos possuem significados idênticos e outras que sequer veem elo entre elas.

Definições incipientes nos dão indícios de que uma rede social remete a determinados grupos de pessoas com qualquer tipo de relação ou interesse mútuo no ambiente online ou de internet. São os chamados sites de relacionamento. Já as outrora denominadas new media (novas mídias) agora são conhecidas como mídias sociais. E, se antes se referiam ao poder de divulgar conteúdo fora dos grandes meios de comunicação de massa, agora são traduzidos por muitos como ferramentas online utilizadas para veicular informações, ao mesmo tempo em que permitem e promovem alguma relação com outras pessoas, pois enquanto disseminam conhecimentos, amenidades, temas em geral, abrem espaço para que os leitores interajam. Em outras palavras, ferramentas cujo objetivo é o compartilhamento de conteúdo, ficando as relações entre os participantes em segundo plano.

[...] A noção de senso comum de hospitalidade já revela o processo de comunicação entre aqueles que visitam e aqueles que recebem em uma determinada localidade turística. Como as ciências da comunicação auxiliam no estudo deste processo? Também a comunicação sofre diante da amplitude do desafio de estudar um campo no qual se desenrola um processo ainda mais complexo, com três elementos em permanente "feedback" - o emissor (e sua mensagem), o canal (contato pessoal entre o emissor e o receptor) e o receptor (e a forma como ele elabora a mensagem recebida, condição para o início do processo de feedback). (NEVES e ALEXANDRE, 2006, p.8)

Por ora, pode-se listar constituição de novos laços de identidade coletiva, volume e velocidade de acesso às informações como características que aproximam esses dois fenômenos da sociedade contemporânea - turismo e internet. Trata-se de duas forças que vêm conquistando tanto empresas - pelas possibilidades de destinarem-se a estratégias corporativas - quanto o público - por possibilitar a participação ativa do usuário na produção de conteúdos e na utilização personalizada de informações e dados, desafiando instituições que lidam com riscos de imagem e com grande diversidade de públicos.

[...] A lógica do funcionamento de redes, cujo símbolo é a Internet, tornou-se aplicável a todos os tipos de atividades, a todos os contextos e a todos os locais que pudessem ser conectados eletronicamente. (CASTELLS, 2013, p.89) 
Neste estudo, a abordagem ater-se-á às plataformas para as quais o texto é determinante: site e Facebook. Isso porque a linguagem utilizada apresenta-se como objeto de análise, tendo em vista que conteúdo, mensagem e informação dependem da comunicação.

A comunicação simbólica entre os seres humanos e o relacionamento entre esses e a natureza, com base na produção (e seu complemento, o consumo), experiência e poder, cristalizam-se ao longo da história em territórios específicos, e assim geram culturas e identidades coletivas. (op.cit., p.52)

A pesquisa em tela procura refletir, por meio da análise de discurso, como o Banco processa essa comunicação na construção do CCBB como lugar em que se manifesta uma peculiar característica do Turismo, a hospitalidade, e se o faz conscientemente, ciente de que “a linguagem é a principal fonte de poder" (HALLIDAY, 2003, p. 47). Nesse sentido, a ideia de comunicação é partilhada com o pensamento de Hannah Arendt, quando esta nos lembra da importância, para a compreensão das coisas, da existência de um ser dotado do ato da fala. Logo, quem fala detém o poder. No entanto, esse "poder nunca é propriedade de um indivíduo; pertence a um grupo e existe somente enquanto o grupo se conserva unido" (ARENDT, 2007, p.123).

Quando se trata da divulgação do Centro Cultural Banco do Brasil pela mídia e rede sociais, tal entendimento apresenta uma possibilidade de reflexão sobre o lugar da fala, a partir de quem profere o discurso. Esclarece-se, ainda, para fins deste estudo, que o lugar da fala é do anfitrião, pois no site e nas redes sociais, ao contrário do que pode aparentar, não há democratização, conforme entendimento de Fairclough (2001, p.248), que toma "por 'democratização' do discurso a retirada de desigualdades e assimetrias dos direitos, das obrigações e do prestígio discursivo e linguístico dos grupos de pessoas".

[...] O surgimento da sociedade em rede [...] não pode ser entendido sem a interação entre estas duas tendências relativamente autônomas: o desenvolvimento de novas tecnologias da informação e a tentativa da antiga sociedade de reaparelhar-se com o uso do poder da tecnologia para servir a tecnologia do poder. [...] (CASTELLS, 2013, p.98)

Os locutores são os detentores da voz ativa. A história nos mostra que as ideologias são sempre determinadas pelos interesses dominantes, que são as relações de poder, como se exerce na comunicação (BOURDIEU, 1989). E a maior e mais longeva instituição financeira do país está atenta às novas formas de tecnologia. 


\subsection{No campo da rede}

No campo minado da informação, o Turismo é um fenômeno inventado, que nasceu e vem se desenvolvendo no âmago da sociedade complexa. Suas múltiplas facetas dão ao lugar um espaço privilegiado no contexto de seus estudos, porque é nesse território que ocorrem as condições para o turismo urbano, com o qual o cidadão se identifica e se apropria. A ele o visitante se dirige atraído pela comunicação que se faz da oferta, do produto cultural, no caso abordado - o Centro Cultural Banco do Brasil Brasília. Ao fazer-se mecenas de um destino turístico urbano, o Banco, por meio da linguagem, corporaliza seu símbolo dentro da cultura, instituindo uma relação de acolhimento, de bem receber o visitante. $\mathrm{O}$ estudo reflete sobre como o CCBB DF, por meio do discurso proferido no site (www.bb.com.br/cultura) e em sua página no Facebook (www.facebook.com/ccbb.brasilia) comunica-se a si mesmo como lugar de visitação para o turista a partir da categoria hospitalidade.

A apresentação do estilo virtual da hospitalidade pode ser considerada um advento ousado e um tanto abstrato. Porém, a inclusão desta categoria se torna extremamente necessária para estabelecer meios de interação entre a população em geral e os governos, cidades e países. Sites da internet demonstram o quanto é significante receber e enviar mensagens hospitaleiras, ou seja, mensagens acolhedoras que não agridam e que vão de encontro aos interesses do receptor. (NEVES e ALEXANDRE, 2006, p.5)

Nesse sentido, Neves et al lembram que é pela comunicação que se estabelece o primeiro contato do visitante com o espaço. E não há visita se não houver relacionamento, o qual se dá a partir da comunicação, cuja origem do verbo está no latim "communicare", que significa "por em comum".

Registre-se, embora igualmente se compreenda, a ausência de menção às formas modernas de uma hospitalidade que bem pode chamar de virtual e que tem certificado de nobreza, com reflexões, ainda que resumidas, de Derrida $(2001)^{26}$. A ausência de referências à implicação dos deveres de hospitalidade na comunicação virtual é, assim, mais fruto das indecisões teóricas sobre a abordagem do tema do que sua importância, de resto crescente e a exigir estudos aí focados. (CAMARGO, 2011, p.14)

Camargo expõe sobre a vacância de estudos em torno de um importante tema da atualidade, a hospitalidade no espaço virtual. A justificativa passa pela falta de consenso teórico, que, como de praxe no universo acadêmico, demanda tempo, critérios sobre os quais

\footnotetext{
${ }^{26}$ DERRIDA, J. Cosmopolitas de todos os países, mais um esforço! Coimbra: Minerva, 2001.
} 
debruçar e pesquisadores interessados em avançar nas reflexões sobre as constantes mudanças do mundo contemporâneo.

Nesta pesquisa, tem-se o CCBB Brasília como o lugar para onde as pessoas se deslocam para acompanhar seu calendário próprio de eventos por encontrarem ali interesses comuns. E parte delas comparece, por meio de um chamado realizado pelo meio virtual. Nesse espaço, é preciso considerar, dentre outros: tema abordado, público-alvo e linguagem. É preciso lembrar que, para realizar o serviço da comunicação digital, o Centro contrata, por meio de licitação, uma empresa especializada, assim como faz com os projetos artísticos.

Desse modo, entende-se que o Centro extrapola sua função de polo atrativo, posto que se trata de espaço dotado de infraestrutura, com programação qualificada, sedimentado no pilar da interseção informação-cultura-turismo-anfitrião-turista. E tudo começa com um convite ao acolhimento.

[...] A hospitalidade pode dizer-se e manifestar-se por meio de muitas maneiras: pelas palavras, pelos gestos, pelas leis e pela pluralidade imensa de formas de gerir os tempos e os espaços que nos coube viver. [...] (BAPTISTA, 2002 p. 161)

Como "banco de mercado com espírito público", "competitivo e rentável, atuando com espírito público em cada uma de suas ações junto a toda a sociedade", o principal mecenas do $\mathrm{CCBB}$ entende que todo e qualquer cidadão é um cliente em potencial e, com isso, é seu público referencial. No caso do Centro, não há discriminação, nem mesmo para clientes de empresas concorrentes. Na rede e no próprio espaço, todos têm os mesmos acessos aos eventos, com oportunidades iguais. Existem, porém, algumas exceções, que beneficiam os detentores de conta no BB: a cota de ingressos destinada ao patrocinador é utilizada para o marketing de relacionamento, com clientes sendo convidados para pré-estreias e visitas guiadas exclusivas, além do privilégio de adquirir ingressos pela metade do preço, assim como professores, estudantes, idosos e outros casos exigidos por lei.

Indaga Pierre Lévy

De que lugar julgamos a informática e os estilos de conhecimento que lhe são aparentados? Ao analisar tudo aquilo que, em nossa forma de pensar, depende da oralidade, da escrita e da impressão, descobriremos que apreendemos o conhecimento por simulação, típico da cultura informática, com os critérios e os reflexos mentais ligados às tecnologias intelectuais anteriores. (LÉVY, 1993, p.19) 
A familiaridade com a rede oferece uma perspectiva para a conexão com o filósofo francês:

\begin{abstract}
A comunicação eletrônica está presente na vida de nossos jovens já há bastante tempo. Para essa meninada, nascida no final do século XX, ligar um computador, desenvolver sites, conversar na rede, expressar-se através de blogs, fotoblogs, enviar e-mails ou participar de fóruns é algo absolutamente corriqueiro. (SANTOS, 2007, p.151)
\end{abstract}

Intui-se, com a assertiva acima, que gerações mais jovens são mais propensas ao uso da rede - não descartando as formadas antes da proliferação de computadores, notebooks e aparelhos móveis, com acesso (quase) ilimitado às informações disponíveis nas redes e mídias sociais, bem como sites em geral. A internet é um fenômeno contemporâneo de interação social que se renova a cada dia com a tecnologia. Fato é que as pessoas estão cada vez mais conectadas, seja para se informar ou se comunicar com outras.

A cultura da virtualidade real representa a consolidação do processo que se inicia com a chamada comunicação de massa muito embora a prerrogativa e tendência das novas tecnologias da informação sejam, ao final das contas, a de estabelecer processos interativos individuais na via de mão dupla que constitui a rede mundial de telecomunicações. (VIEIRA, 2006, p.235)

Não se deve esquecer que a comunicação integra e fortalece a condição humana, desempenhando papel essencial no desenvolvimento social. E, na "sociedade em rede" de Castells, a cultura da virtualidade real emerge sob a influência tanto de interesses sociais quanto de governos, empresas e instituições. O sociólogo espanhol alerta que há um preço a ser pago pela inclusão no sistema: a "adaptação" à sua "lógica", à sua "linguagem", à sua “codificação e decodificação" (CASTELLS, 2013, p.461). Nas palavras do teórico, "afirmo que a dominação social é exercida por meio da inclusão seletiva e da exclusão de funções e pessoas em diferentes estruturas temporais e espaciais. [...]" (op.cit.,p.527).

No entanto, como lembra Bessone (2011, p.1091), “a categoria do incluído talvez seja ela própria uma mera ilusão simplificadora, um modelo que se torna o objeto sobredeterminado por ideologias e imaginários coletivos".

Ora, diante da multiplicidade de sentidos dessa noção sem rigor nem sutileza, ao mesmo tempo muito rica e muito pobre, a única maneira de permanecer um incluído é tendo a certeza da continuidade de uma categoria homogênea, a do excluído, que confirma em negativo a existência de um sistema de incluídos. Os excluídos confirmam que os incluídos são, de fato, o que eles pensam ser, o que lhes permite se posicionar em relação aos outros, tomar uma posição a respeito do normal, etc. [...] (op.cit.) 
Como visto no capítulo anterior, a exclusão é relativa, posto que todos são parte integrante da sociedade. Além disso, o universo capitalista não faz distinção de regimes e se desenvolve tanto no ambiente privado quanto no público, pois todos têm o mesmo interesse: atingir a maior audiência possível. Enquanto o Estado visa finalidades político-ideológicas, o sistema privado foca no lucro máximo, pois "quer, antes de tudo, agradar ao consumidor" (MORIN, 1997, p.23). Consumidor contemporâneo esse que "faz da experiência do tempo livre uma mercadoria a ser consumida e assume a interação mediada pela comunicação virtual", como destaca Neves ( 2009, p.4).

\subsection{Construção social da comunicação}

Refletir sobre atualidade requer muito mais que conhecimento histórico e etimológico; exige do investigador abertura para todas as demandas sociais que a este termo se voltam. De imediato, é possível desconstruir a possível distorção de que a noção de atualidade tenha surgido na contemporaneidade. Segundo o professor Wilmont Haacke, pouco antes de 1700 já se formulava a experiência de atualidade (MARTINO, 2012, p.1). Afinal, o hoje é fruto do ontem, do passado, das evoluções tecnológicas e sociais.

Assim, não é o ambiente natural que produz no indivíduo a necessidade de informarse, mas o ambiente social, pois a informação constante nos sites, nas redes sociais, nos jornais, nas revistas, nas emissoras de rádio e nos telejornais corresponde ao mundo globalizado, ao mesmo tempo em que fornece

[...] subsídios ao indivíduo enquanto agente social: emprego e negócios, para o agente econômico; notícias políticas para o cidadão e eleitor (agente político); shows, programação de cinema, exposições, restaurantes e esporte, para o lazer e a cultura (agente cultural). A informação mediática, da qual a notícia é uma parte importante, mas não sua totalidade (é preciso incluir todos os produtos da indústria cultural), é o correlato da ação, é a contrapartida da necessidade do indivíduo se orientar em um ambiente complexo, como o da cultura contemporânea e da sociedade complexa. Ela viabiliza a administração de si, num mundo onde os papéis sociais se multiplicaram e o indivíduo ganhou uma relativa autonomia em relação ao coletivo. (MARTINO, 2012, p. 4).

O ser humano conhece por meio da palavra, essa dimensão simbólica e cultural, conforme tese de Sapir-Whorf. E é na hospitalidade da rede mundial de computadores que atualmente se abriga. Nela, todos são bem-vindos para receber conteúdos diversos que podem ou não colaborar na formação e no desenvolvimento social. 
Se, em um primeiro momento, o impulso da pesquisa, no que tange a comunicação, foi o de simplesmente buscar as raízes e as origens dos meios para dar um tratamento histórico ao papel das redes e mídias sociais na formação do público frequentador do CCBB DF, o que ora se vislumbra são reflexos de uma incipiente imersão em algumas correntes da Comunicação. Uma delas é uma aproximação do objeto de estudo à indústria cultural, com suas intrínsecas contradições e dilemas.

A característica industrial da cultura produz consequências, pois busca a estandardização, a qual se manifesta em uma grade de programação constante nas áreas de artes cênicas, artes visuais, cinema e música, com funcionamento de quarta-feira a segunda. $\mathrm{O}$ espaço precisa estar pronto para receber seu visitante. Toma-se como tendência da natureza do consumo cultural, sempre em busca do novo, do individualizado, a constante superação dessa contradição em sua estrutura. Ciente dessa necessidade, o CCBB Brasília produz arquétipos, fórmulas que permitem algumas mudanças para individualizar o produto. "[...] Compreender a força dos arquétipos é a chave para a união dos contrários, como ápice do processo de evolução humana e espiritual. [...]”. (SERPA, 2014, p.129). A abordagem do professor brasileiro remete ao planejamento turístico no espaço urbano e serve como exemplo das transformações promovidas pelo Centro para manter-se em voga na memória dos turistas.

[...] A contradição invenção-padronização é a contradição dinâmica da cultura de massa. É seu mecanismo de adaptação ao público e de adaptação do público a ela. É sua vitalidade. (MORIN, 1997, p.28).

Essas variações ficam por conta das escolhas dos eventos que abriga. E um público curioso, mas conservador, sente-se atraído por uma exposição clássica, com obras de colecionadores sobre o Renascimento Italiano, ou sobre a civilização iraniana ou indiana, seguida por outra voltada para todas as idades, interativa, vibrante, cheia de cores e da singular história de sua artista, a japonesa Yayoi Kusama, ou as construções surpreendentes e originais do holandês Escher. No campo das artes cênicas, raramente vê-se um programa em que não constem atrizes e atores renomados do teatro, da televisão e do cinema na ficha técnica; ao mesmo tempo, o projeto Seleção Brasil EmCena abre oportunidades para textos inéditos da dramaturgia nacional, os quais são lidos e encenados por estudantes ou artistas recém-formados na academia. Nas apresentações musicais, expoentes da cena brasileira, prestam homenagens a consagrados músicos em arranjos personalizados - mas a velha guarda também tem seu lugar cativo para apresentações. Todos os exemplos formam uma receita comprovadamente de sucesso que levou 1.476.744 visitantes ao longo de 2014 ao CCBB 
Brasília, dando a este o posto de terceiro museu/centro cultural mais visitado do Brasil e o $38^{\circ}$ lugar no mundo (THE ART NEWSPAPER, 2015).

A massa é uma matriz de onde brota, atualmente, todo um conjunto de novas atitudes em face da obra de arte. A quantidade tornou-se qualidade. O crescimento maciço do número de participantes transformou seu modo de participação [...] (BENJAMIN, 2011, p.277).

$\mathrm{Na}$ sociedade de massa, surge o indivíduo como ele quer ser visto pelos outros. A maneira de ele se expressar passa a ser a forma como se veste, a marca do carro que adquire, os lugares que frequenta, como o CCBB. O sujeito adota estereótipos por meio dos quais se apresenta à sociedade e pressupõe estar em processo de comunicação com outros. É uma sensação de pertencimento a um determinado grupo social. No CCBB, porém, todos os tipos de todas as tribos são acolhidos.

Vivemos em uma época repleta de opostos. Esperamos que as organizações existam globalmente e atuem localmente, sejam eficientes e inovadoras e permaneçam lucrativas a curto e longo prazos. Nesse ambiente de crescente complexidade, o foco unidimensional é fatal. (CROSS e THOMAS, 2009, p.55)

Há uma construção social do comum a partir do discurso proferido pelo CCBB por meio do site e do Facebook, que cria identidades e sincroniza experiências. E, assim, o turista é estimulado a ir e vai ao CCBB Brasília. Ao chegar, sente-se partícipe de uma sociedade, de uma comunidade, de um grupo, ao ponto de apossar-se, apropriar-se, do espaço - por exemplo, ao realizar um piquenique, passear pelos jardins, meditar sob a lua cheia, desfrutar de leituras ao ar livre. É o hóspede se apropriando do espaço e fazendo as vezes de anfitrião. O protagonismo do visitante no CCBB DF não ocorre apenas por meio dos eventos que o Centro conduz, mas parte também de ações espontâneas de seus frequentadores.

Um olhar para as características gerais do público do Centro remete a pesquisa ao pensamento do filósofo e sociólogo alemão Axel Honnet, diretor, desde 2001, do Instituto de Pesquisa Social, a partir do qual se originou a expressão "Escola de Frankfurt", no começo do século XX. Para o teórico, enquanto Benjamin via na arte voltada para um grande número de pessoas "novas formas de percepção coletiva", Adorno a percebia como "um processo que força o observador a transformar-se num consumidor passivo e alienado" (HONNETH, 1999, p. 530). O diretor ainda critica seu antecessor, Horkheimer, por não demonstrar 
[...] que os sujeitos socializados não estão apenas passivamente sujeitos a um processo anônimo de direcionamento mas, antes, participam ativamente com seus próprios desempenhos interpretativos no complexo processo de integração social. [...] (HONNETH, 1999, p.515)

O efeito da arte seria, assim, um sintoma e não uma causa. Observa-se que, na sociedade cultural movida pelo capitalismo, o padrão se beneficia do sucesso passado e o original é a garantia do novo triunfo.

$\mathrm{O} \mathrm{CCBB}$, como visto, foi concebido para receber visitantes, oferecendo aos turistas obras de arte em suas variações estéticas e de gênero. O objetivo era colocar a capital federal, já famosa pelos traçados inusitados de Lúcio Costa e arquitetura ímpar de Oscar Niemeyer, na rota de importantes exposições. A cidade, por si só, nascera com vocação para receber. A estratégia para aumento da percepção turística, grosso modo, assemelha-se à da narrativa de Camargo:

[...] Não é por acaso que, exatamente nessa perspectiva de cidade hospitaleira, surgiu o mais antigo evento da sociedade contemporânea: as exposições internacionais, a primeira delas a de Londres, em 1844, e que até hoje são realizadas com intervalos de dois a três anos em cidades que igualmente disputam acirradamente o privilégio de acolhê-las e de hospedar os visitantes (turistas) de forma digna. [...] (CAMARGO, 2011, p.19)

Camargo, em sua dimensão histórica, ressalta, ainda, outro fato marcante daquela exposição:

[...] Pela primeira vez na história, um evento é organizado sem a inspiração e/ou o controle do poder sociorreligioso, com a participação crescente da iniciativa empresarial, tornando-se mais uma peça na engrenagem da economia capitalista. (op.cit.)

O CCBB nasceu da iniciativa de uma instituição de economia mista. O edital público de seleção de projetos realizado pelo Centro, transparente aos olhos da sociedade, garante o controle sobre o que se pretende mostrar, sempre com a perspectiva de que o público compareça e prestigie os programas escolhidos.

Infalivelmente, cada manifestação particular da indústria cultural reproduz os homens como aquilo que foi já produzido por toda a indústria cultural. E, no sentido de impedir que a simples reprodução do espírito não conduza à sua ampliação, vigiam todos os seus agentes, desde o produtor até as associações femininas.[...] (HORKHEIMER e ADORNO, 2011, p.191) 
Nas palavras de Montandon (2011b, p.997), "a hospitalidade é uma interação social que também cria ligações profissionais e pessoais". Assim, refletir sobre a divulgação de shows, espetáculos, exposições, do que ocorre aqui e agora, na atualidade, exige do investigador abertura para todas as demandas sociais que a este termo se voltam. Não é o ambiente natural que produz no indivíduo a necessidade de informar-se, mas o ambiente social, pois a informação constante nos sites, nas redes sociais, nos jornais, nas revistas, nas emissoras de rádio e nos telejornais corresponde ao mundo globalizado, do qual visitante e anfitrião são partícipes.

Na clássica definição de Marshal McLuhan, um meio dá forma à mensagem; o meio, portanto, não é exatamente a coisa, o suporte, mas o uso que dele se faz. Em pauta, uma viagem de experiência, requisito importante do Turismo, pois "a comunicação, predominante no fenômeno turístico, visa tocar o outro, favorecer o contato com o outro, seja direta ou indiretamente" (MOESCH, 2002, p. 41).

Com essas premissas, os estudos caminham na investigação de como o CCBB DF, por meio de seus canais de comunicação digital (Galáxia de Marconi), constrói e estabelece um discurso que solidifica sua identidade como lugar de acolhimento e visitação turística. Ao mesmo tempo, averigua se, pelos mesmos meios, o visitante é interpelado pela ideologia, por meio dos "implícitos", os quais, de acordo com Fairclough (2001), são sempre precedidos de contextos de informação e cultura, sendo por estes interpretados e ressignificados.

[...] A comunicação, a informação, a desmaterialização das trocas indicam uma nova fluidez do real que, à primeira vista, descolou-se do grande peso. Ora, nesse fingimento existe encantamento, encriptamento.[...] Nós nos evadimos nas redes da Web para melhor nos fecharmos num dado lugar e num dado tempo ali inscritos. Vejo nisso também um atestado da condenação dos povos nômades e de toda transumância. [...] (DERRIDA, 2003, p.112 e 114)

Acima, Derrida é convidado por Anne Dufourmantelle a tratar do "mundo estruturado pela ausência" de um interlocutor, ao mesmo tempo em que ambos mantêm "relação com o terceiro, linguagem, ética, transcendência" (op. cit., p. 110 e 112). Cultura, sociedade, técnica, todos se relacionam entre si, bem como as representações de mundo modificadas pela tecnologia. Daí uma característica a se considerar em relação à hospitalidade dada no discurso proferido pelo $\mathrm{CCBB}$.

Entre as práticas textuais existem relações, mais ou menos manifestas, que, de um modo metafórico, evocam a hospitalidade: um texto acolhe outro, pode ser seu abrigo, seu refúgio, pode fazer dele o convidado de honra, ou 
pode lhe fazer dom de si, o que constitui, no sentido figurado, um ato de hospitalidade que se faz e se desenrola no nível da literatura, ou no nível mais geral e mais generoso da cultura e mesmo no nível do texto infinito do mundo. (CONSTANTINESCU, 2011, p.669)

A literatura nos mostra que um conhecimento nunca é absoluto; pois ele é sempre gerado na relação com outros conhecimentos. E na cultura mediada e determinada pela comunicação, nossos códigos são transformados pelo novo sistema tecnológico e o serão ainda mais com o passar do tempo (CASTELLS, 2013, p.414).

Quando vivíamos em uma sociedade em que o indivíduo humano era a referência, tudo remetia a esse indivíduo, ou a essa figura do homem. E quando passamos para uma sociedade em que a informação é o principal, a medida de todas as coisas, tudo passa a ser remetido à informação.[...] (SANTOS, 2001, p.31)

Como alerta Santos, é preciso começar a mudar a maneira de pensar a relação do homem com a tecnologia, e não apenas com a tecnologia da informação. O homem contemporâneo tem uma relação puramente utilitária com a tecnologia. Ele acredita que a utiliza como e quando quer, deixando-a de lado quando não mais necessita; e crê que seu uso não exerce nenhum efeito mais profundo sobre a própria humanidade. "Usamos e depois descartamos, desligamos e pronto." (op.cit., p.40). Quando faz isso, supõe que a sensibilidade humana e também a natureza humana têm uma existência completamente separada da realidade tecnológica. O desdobramento do chamado do $\mathrm{CCBB}$ ao visitante pela internet prova o contrário. 


\section{CAPÍTULO 5 - UM CAMPO DE PRÁTICAS HISTÓRICO-SOCIAIS}

"Quando um pensamento nos domina, nós o encontramos expresso em todos os lugares, nós o cheiramos até no vento."

Thomas Mann

Nos primórdios da chamada civilização, a pesquisa era considerada meramente um estudo teórico, sem experimentações que testassem e atestassem as hipóteses e suas variáveis. Embora as bases para a construção do conhecimento de forma sistematizada se deva à Idade Média e ao Renascimento, a associação da teoria com a prática de forma contextualizada, holística e sistêmica é um privilégio da contemporaneidade (OLIVEIRA, 2007).

O rigor necessário para que o pesquisador conheça o que deseja conhecer, ou seja, o seu objeto de análise, é fruto do pensamento científico moderno, em cuja base encontra-se o fato. Importa, antes, lembrar que, desde a categorização de Aristóteles, passando pela racionalização de René Descartes e o pensamento complexo de Edgar Morin, o método científico vem sendo transformado, à medida que o mundo também se transmuta - e com ele o sujeito.

Sujeito contingente, o homem é fruto de práticas histórico-sociais, sendo dialético em seu modo de pensar e agir. E é, na pesquisa, quem observa e se relaciona com seu objeto de estudo, situado num tempo e num espaço que ele mesmo apreende e examina à luz de conceitos e metodologias disponíveis. Essa aproximação consciente delimita seu campo de saber, do mesmo modo que produz e desenvolve a "potencialidade disruptiva" do conhecimento científico, por meio da qual "o ser humano se rebela e confronta com todos os seus limites, transformando-os em desafios" (DEMO, 2003).

O conhecimento científico depende de um esforço, de uma busca constante por parte do investigador, que inicia sua trajetória pelo encontro do método, do caminho a ser percorrido para se chegar ao saber. Faz-se imprescindível que o pesquisador saiba qual direção tomar, qual regra adotar, pois ela deve ser pertinente ao objeto de estudo. Tal rigor visa ao que se constituirá como conhecimento novo, a ser validado por um conjunto de critérios que auxiliarão o cientista na confirmação da discussão inserida no problema de estudo. Daí a contribuição da Análise de Discurso (AD) na construção do CCBB DF como lugar de acolhimento ao visitante, por meio do discurso produzido nas páginas de seu site e Facebook. 
[...] Na realidade, não são palavras o que pronunciamos ou escutamos, mas verdades ou mentiras, coisas boas ou más, importantes ou triviais, agradáveis ou desagradáveis, etc. A palavra está sempre carregada de um conteúdo ou de um sentido ideológico ou vivencial. É assim que compreendemos as palavras e somente reagimos àquelas que despertam em nós ressonâncias ideológicas ou concernentes à vida. (BAKHTIN, 2009, p.98-99)

$\mathrm{Na}$ apreciação sobre o tema “O CCBB como anfitrião: uma reflexão sobre o turismo e a hospitalidade a partir do discurso proferido pelo Centro Cultural Banco do Brasil Brasília no site e no Facebook", leituras apontam que a análise do discurso apresenta-se como método a ser trabalhado. Por meio dele, percebe-se como o discurso hospitaleiro do CCBB Brasília na rede e na mídia social, a partir da linguagem adotada no mundo virtual concebe, constrói o espaço como destino turístico e, ao mesmo tempo, o divulga, conquistando e atraindo o público visitante.

\subsection{Formação nas prioridades}

A ciência depende do princípio da dúvida e, por mais que um método ou doutrina pareçam estabelecidos e aceitos, eles sempre estarão abertos a outras proposições. A incerteza é um atributo da modernidade. Assim, sejam quais forem os referenciais teóricometodológicos do pesquisador, bem como seus interesses e compromissos sociais, ele precisa evidenciar, dentre seus objetivos, a ampliação do conhecimento e a explanação de sua teoria. Para tanto, como adverte Luna (2002, p.74), é preciso que se confira "generalidade" aos resultados, indo para "além da constatação das informações" coletadas.

\footnotetext{
A teorização depende de um esforço de generalização e de um esforço de individualização. A generalização nos dá a listagem das possibilidades; a individualização nos indica como, em cada lugar, algumas dessas possibilidades se combinam. (SANTOS, 2008, p. 65)
}

Para reunir dados e fatos sobre o objeto a ser pesquisado, o investigador precisa partir da realidade que se lhe apresenta o discurso contido nas páginas do site e as postagens no Facebook produzidas para divulgar e promover o espaço do CCBB DF, entre abril de 2014 e abril de 2015. No entanto, essa realidade não pode se impor. O observador do fato deve ter claro que ele é sujeito e condutor da análise, sendo responsável pela reconstrução do significado e do significante de seu estudo, sob orientação, especialmente, de dois decisivos eixos: o "evolucionário" - relativo ao "equipamento cerebral" - e o "cultural" - caracterizado "pelos modos históricos de lidar com a realidade, com realce para a linguagem" (DEMO, 2003). Nesse sentido, os estudos de Foucault contribuem para os fundamentos da pesquisa na 
construção discursiva de poder, além do funcionamento da linguagem no âmbito das relações sociais.

Essa produção de conhecimento novo, criativo, encontra obstáculos, ao mesmo tempo em que se submete ao rígido controle do pesquisador. Na expressão cunhada por Gaston Bachelard em "A poética do espaço", trata-se da "vigilância epistemológica", na qual é imprescindível o permanente cuidado que o investigador necessita ter para com os conceitos, as condições de captação de dados e os limites da validade de técnicas utilizadas para se obter o tão desejado conhecimento. Cabe ressaltar que, ao optar por uma metodologia, o investigador se posiciona e assume os riscos em relação às teorias explicativas a serem adotadas por ele. Um dos cuidados a serem tomados é com o conceito de prática discursiva com o qual a pesquisa será desenvolvida, se a relativa à vertente francesa, na qual as palavras não são autônomas, mas se realizam nas práticas discursivas e nas relações sociais (tendo como expoentes Foucault, Orlandi e Maingueneau), ou se na direção inglesa, segundo a qual nos estudos críticos do discurso, observa-se tanto a interioridade da língua (gramática) quanto sua funcionalidade nas relações sociais (inclinação representada por Fairclough).

Apesar de o pesquisador que busca o conhecimento novo procurar afastar-se da ideia de senso comum, nem sempre ele conseguirá abster-se de determinadas premissas. Uma delas é a constatação de que a ciência é uma construção do ser humano - et nec plus ultra. Mas não se trata de uma elaboração qualquer, pois ela deve ser concebida a partir da percepção do cientista em trazer consigo um método capaz de oferecer a ela autenticidade, auxiliando-o na explicitação do objeto, que, por seu turno, deverá ser tomado a partir de uma concepção crítica, a fim de não perder seu caráter de cientificidade.

Inferir, pela observação a olho nu e não sob a luz da ciência, que o CCBB DF possui uma trajetória de sucesso junto ao público visitante, devido à programação que oferece e à divulgação eficaz de seu espaço, significa infirmar o valor do conhecimento sistematizado, capaz de reconhecer a exploração da linguagem, por meio do universo da cultura dentro das redes sociais. Enfrentar a realidade sem critérios metodológicos pode significar, dentre outras mazelas, não se chegar a lugar algum.

Para desenvolver sua função, o pesquisador deve interpretar a realidade observada. $\mathrm{Na}$ abordagem de Sérgio Luna:

[...] abandonou-se (ou, vem-se abandonando) a ideia de que faça qualquer sentido discutir a metodologia fora de um quadro de referência teórico que, por sua vez, é condicionado por pressupostos epistemológicos. O reconhecimento do poder relativo da metodologia tem por trás outra 
decorrência da evolução do pensamento epistemológico: a substituição da busca da verdade pela tentativa de aumentar o poder explicativo das teorias. [...] (LUNA, 2002, p.14)

Na perspectiva de Creswell (2007), toda ciência desenvolve-se dentro da matriz disciplinar dominante, de base aristotélica, resolvendo os problemas nos limites estabelecidos por esse paradigma. Quando surge uma questão que não pode ser resolvida dentro da visão dominante, tem-se uma crise que será solucionada apenas com o surgimento de um novo paradigma.

Nas ciências modernas, espera-se que o cientista atue de forma relevante teórica e socialmente, demonstrando a produção de seu conhecimento de modo fidedigno, por meio de critérios convincentes. Santos (2005, p. 28) lembra ao pesquisador que "conhecer significa dividir e classificar para depois poder determinar relações sistemáticas entre o que se separou". Em sintonia, Morin (2011) afirma não haver uma base empírica simples e lógica para a resolução dos problemas que se apresentam. Para o pensador francês, o simples não é o fundamento de todas as coisas, mesmo porque não há solo firme na ciência; nela, nem mesmo espaço e tempo são entidades absolutas e independentes.

Para desenvolver novos paradigmas, visões de mundo, conceitos e valores que orientem as investigações científicas, no entanto, é preciso lançar mão da via especulativa. Tal especulação deve ser aquela iniciada nas pistas emitidas e deixadas pelo que Boaventura Santos denomina de "paradigma dominante" e que se orientarão para o "paradigma emergente", no qual o conhecimento é constituído pela pluralidade. Para o autor português, o paradigma dominante vive uma crise irreversível, devido à diversidade, à ampliação dos campos do conhecimento e das condições da sociedade moderna. Tal afirmativa remete novamente a Morin e sua advertência de que as ciências devem tentar ser precisas no reino da imprecisão. A ciência moderna, ao contrário da ciência aristotélica, conjetura e suspeita de modo sistematizado das evidências do objeto.

No entender de Morin, o paradigma da simplificação, originado em Descartes, separou o sujeito pensante (ego cogitans) da coisa pensada, entendida (res extensa). Durante muito tempo - e ainda hoje - essa redução quanto à percepção do objeto controla a aventura do pensamento ocidental. Segundo o autor, o pensamento simplificador é incapaz de conceber a conjunção do uno e do múltiplo - ou ele unifica abstratamente ao anular a diversidade ou, ao contrário, justapõe a diversidade sem conceber a unidade. Não enxergando o princípio de que a parte está no todo, mas percebendo que não só a parte está no todo como o todo está no interior do todo. Para Morin, os modos simplificadores de conhecimento mutilam mais do que 
exprimem as realidades ou os fenômenos de que tratam, produzindo mais cegueira que elucidação. O pensamento simplificador possui limitações, ineficiências e carências, enquanto o pensamento complexo é um desafio do qual o cientista não deve se desvencilhar.

$\mathrm{Na}$ investigação em curso, que pretende estabelecer as condições de acolhimento ao turista no espaço do CCBB DF, por meio da linguagem, percebe-se como o todo (CCBB, com sua programação, divulgação e espaço) está nas partes (cultura nas acepções de arte e práticas sociais; lugar; espaço; convivência; turista; cidadão; ser social; integração) e vice-versa. Talvez por apresentar-se multifacetada e diversamente seja possível observar o quanto o visitante se apropria daqueles $20.551 \mathrm{~m}^{2}$ de área, por exemplo, ao atender ao chamado da visita, diga-se, de modo enviesado. É o caso do piquenique realizado por inteiras famílias e grupos de amigos, nos jardins - iniciado de forma espontânea pelo turista, e não a partir de um convite formal do CCBB DF para que o fizesse. Esse, a partir dessa apropriação do espaço pelo público, posteriormente, adota tal prática e a estimula, abrigando eventos da cidade. "O grupo transforma seu espaço à sua imagem e a ele se adapta" (YÁZIGI, 2001, p. 36).

[...] Todos os papéis sociais são relações que o indivíduo estabelece com outros, a informação do ambiente social nada mais é que a contrapartida necessária desta ação, que caracteriza o indivíduo moderno. [...] (MARTINO, 2012, p. 4)

Sendo disciplinado, o conhecimento moderno tem o saber organizado e orientado para observar as fronteiras entre as disciplinas e conter os que pretendem transpô-las. Nele paradigma emergente -, os temas se encontram e o conhecimento avança na medida em que o objeto ganha interfaces e estimula "os conceitos e as teorias desenvolvidos localmente a emigrarem para outros lugares cognitivos, de modo a poderem ser utilizados fora do seu contexto de origem" (SANTOS, 2004, p.77). Como afirma o autor de "Um discurso sobre as ciências", o conhecimento pós-moderno não é nem determinante nem descritivo; ele trata das condições, das possibilidades, pois a realidade vai redarguir na língua em que for perguntada e, sabe-se, cada método possui uma linguagem própria, particular.

Sob essa perspectiva, Santos ainda observa que, no paradigma emergente, o objeto é a continuação do sujeito e todo conhecimento científico é também autoconhecimento. Para tanto, é necessário que a distinção epistemológica entre sujeito e objeto se articule metodologicamente a partir da distância empírica entre ambos.

[...] A ciência moderna não é a única explicação possível da realidade e não há sequer qualquer razão científica para considerá-la melhor que as 
explicações alternativas da metafísica, da astrologia, da religião, da arte ou da poesia. A razão por que privilegiamos hoje uma forma de conhecimento assente na previsão e no controle dos fenômenos nada tem de científico. É o juízo de valor. [...] (SANTOS, 2004, p.83-84)

Assim, a explicação científica dos fenômenos dá-se pelos meios que a própria ciência encontra para justificar a si mesma enquanto fenômeno central do mundo contemporâneo. Esse caráter autobiográfico é plenamente assumido no paradigma emergente. Nele, legados da ciência moderna, como o conhecimento funcional do mundo e a incerteza (como limitação técnica destinada a ser superada) possibilitam, respectivamente, uma ampliação das perspectivas de sobrevivência e o entendimento de que o mundo deve ser contemplado e não controlado.

Para o professor português, a analogia textual, lúdica, está entre as categorias matriciais do paradigma emergente: "o mundo é comunicação e por isso a lógica existencial da ciência pós-moderna é promover a situação comunicativa tal como Habermas a concebe" (SANTOS, 2004, p.73).

O dilema na busca pelo método epistemológico que possa melhor evidenciar a pesquisa encontra na investigação qualitativa uma opção para o cientista. Schwandt (2006) estabelece três posturas epistemológicas para a investigação qualitativa - interpretativismo, hermenêutica e construcionismo social. Essas filosofias, segundo o autor,

[...] seguem diferentes perspectivas quanto ao objetivo e à prática da compreensão da ação humana, de diferentes compromissos éticos e de diferentes posturas em relação a questões metodológicas e epistemológicas que envolvam a representação, a validade, a objetividade, e assim por diante. [...] (SCHWANDT, 2006, p. 194)

O interpretativismo reflete o olhar de quem observa. É ele quem vai encontrar o significado para a ação. Braços estendidos podem ser entendidos como convite a um abraço ou chamada a um taxi, um sorriso pode ser interpretado como terno ou forçado. A contextualização e a interpretação do significado de imagens, sons, depoimentos e documentos transcendem o aqui e agora, o ambiente histórico. Cabe ao investigador compreender o todo, o complexo de intenções, crenças, o texto ou o contexto da linguagem.

Como constata Yázigi, não se é turista em tempo integral: "O turismo deve ser encarado como momento da vida; avaliado em seu espaço de tempo." (YÁZIGI, 2001, p.19). Observa-se que o cidadão brasiliense desperta para o turismo dentro da própria cidade. Não para o turismo cívico, tão característico das capitais federais, e no qual os visitantes voltam seus olhares para prédios e monumentos públicos nos quais são decididos os destinos da 
nação, mas para lugares nos quais identifica como de lazer, entretenimento, de reconhecimento de culturas, de encontros. O CCBB DF preenche essa característica na vida social, como prova o número crescente de visitantes que vem recebendo ao longo dos anos.

A hermenêutica filosófica sustenta que a compreensão é a interpretação e, por isso, não é controlada por regras. Por outro lado, "a compreensão é algo produzido" dialeticamente.

Nesse sentido, a hermenêutica filosófica opõe-se a um realismo ingênuo ou objetivismo no que diz respeito ao significado, e pode-se dizer que defende a conclusão de que nunca existe uma interpretação definitivamente correta. [...] (SCHWANDT, 2006, p. 199)

As epistemologias construcionistas sociais rejeitam a representação, interessando-se pelo modo como "funcionam" os enunciados, compreendendo as "práticas sociais e de análise das estratégias retóricas que estão em jogo em determinados tipos de discurso". Schwandt recorre a Rouse $(1996)^{27}$ para indicar que, no construcionismo social, o conhecimento "não é desinteressado, apolítico [...] mas é, de certa forma, ideológico, político e permeado por valores" (SCHWANDT, 2006, p. 202).

Nota-se que as três posturas epistemológicas - interpretativismo, hermenêutica e construcionismo social - analisadas pelo professor Schwandt oferecem modos distintos de lidar com a grande questão da investigação qualitativa: a profunda preocupação com a compreensão. Para tanto, deve empregar recursos que impõem três questões:

[...] (a) como definir o verdadeiro significado da "compreensão" e como justificar as alegações do "compreender"; (b) como formular o projeto interpretativo, concebido em linhas gerais; e (c) como prever e ocupar o espaço ético no qual os pesquisadores e pesquisados (sujeitos, informantes, entrevistados, participantes, co-pesquisadores) relacionam-se entre si na ocasião ou no evento sociotemporal que é a "pesquisa", e, consequentemente, como determinar o papel, o status, a responsabilidade e as obrigações do pesquisador na sociedade que ele pesquisa e para com esta. [...] (SCHWANDT, 2006, p. 205)

Independentemente da escolha epistemológica do cientista, na análise, ele não deve se furtar a compreender e justificar sua compreensão, quanto ao seu objeto de interesse e sobre o método escolhido para investigá-lo.

E, assim, a Análise de Discurso apresenta-se como um caminho a ser percorrido no processo de reconhecimento das questões que norteiam o $\mathrm{CCBB} \mathrm{DF}$, em termos de

\footnotetext{
${ }^{27}$ ROUSE, J. Feminism and the social construction os scientific knowledge. In: L. H. Nelson \& J. Nelson (eds.), Feminism, science, and the philosophy os Science. Dordrecht, Netherlands: Kluwer, 1996, p.195-215.
} 
territorialidade, identidade cultural e, principalmente, hospitalidade, no que se refere à experiência turística vivenciada pelo sujeito.

Foucault, em seus estudos sobre as relações de poder, considerava este, o poder, capaz de reconhecer como se produzem os saberes e como os seres se constituem na articulação entre ambos. Para o filósofo, as sociedades não são livres de relações de poder, e cunha o conceito de "biopoder", no qual "discurso" e "linguagem" se concentram no coração das práticas e dos processos sociais modernos.

O Banco do Brasil, por meio do discurso, apresenta-se como fomentador de cultura, um mecenas, apropriando-se de um linguajar de informalidade para penetrar no espaço, materializando seu símbolo dentro de outros universos, o cultural e o turístico. O cultural, porque se empenha em oferecer à cidade uma programação exclusiva, intensa, diversificada, abrangente do universo artístico do Brasil e do mundo. E o turístico, porque faz de si mesmo um destino, um lugar de encontro para o turista, residente ou não na capital federal, que se sente atraído pela programação e pela acolhida com a qual se depara desde que recebe o convite pelo meio virtual até o desfrute do ambiente e da programação in loco. Nas palavras de Neves (2009, p.7), “a interação social mediada pela hospitalidade pressupõe um processo de comunicação entre aquele que visita e aquele que recebe."

\subsection{Partilhas disciplinares}

$\mathrm{Na}$ antiga Grécia, naquela que é considerada o berço do pensamento ocidental, o filósofo Sócrates originou o chamado método socrático. Por meio do diálogo, ele induzia o próprio aluno a encontrar dentro de si mesmo as respostas que procurava. Tal interlocução, no entanto, consistia em duas fases: a ironia, que fazia o discípulo enxergar sua própria ignorância, e a maiêutica, na qual fazia aflorar suas ideias (ROSA, 1993, p. 39). O discípulo, por meio desse método, propagado por Platão, era estimulado a pensar, mas longe dos livros. O mesmo mundo helênico, porém, descobriu que o método socrático era adequado a determinadas situações, mas não a todas. Sujeito a restrições, não poderia responder a todas as inquietações do homem.

Os temas adequados ao método socrático são aqueles de que já possuímos conhecimento suficiente para chegarmos a uma conclusão acertada, mas que não alcançamos por confusão de espírito ou por falta de análise e da qual não temos proveito. Uma pergunta, por exemplo, como 'que é a justiça?' é sumamente adequada para discussão num diálogo platônico. [...] (ROSA, 1993, p. 40) 
Um estagirita denominado Aristóteles, discípulo de Platão e preceptor de "Alexandre, o Grande", legou à posteridade o aprofundamento do saber, por meio da investigação pela razão. Séculos mais tarde, René Descartes reafirmava a soberania desta ao assegurar que ao ser humano e somente a ele era dada a razão, fonte de todo conhecimento seguro e verdadeiro.

A ciência moderna ganhava um meio de se relacionar com seus fenômenos, fatos e mistérios. Ocorre que o sujeito investigador está vinculado ao seu tempo. É por ele e nele que se inteira de sua realidade e por esta é naturalmente transformado. $\mathrm{O}$ cientista contemporâneo descobre que é preciso derrubar as barreiras do senso comum quanto ao que vem a ser o mundo, a fim de melhor compreendê-lo e interpretá-lo. As destruições causadas por um tsunami ou um terremoto no oceano Pacífico ou Índico deixam vivo nas pessoas o brutal poder das forças naturais em ação. Nesses casos, a interferência humana é inexistente - ou, quando há, invisível. Pode isso estar relacionado à incapacidade do ser humano de antecipar as consequências, de ficar impassível frente à sua inabilidade para decifrar fenômenos enganosos de uma normalidade instável ou mesmo de enxergar tendências desastrosas dos que usam ou administram recursos naturais.

Em pleno século XX, o investigador se depara com um desafio - o de que seu trabalho, o seu problema, não é o de trazer à luz respostas ou soluções, mas o de pensar, como afirma Morin (2011), por meio de infinitas "retroações, incertezas e contradições". Não se trata de tarefa simples. Ao contrário, pois como nos mostram a Psicanálise e a História, o que se apresenta o faz por inteiro, com seus desejos obscuros, lutas, dominação, poder.

Nesta pesquisa, a temática se volta para a análise do discurso do BB produzido no site e na página do CCBB Brasília no Facebook, por meio da qual o Centro se transforma em um destino turístico a partir da categoria hospitalidade. Essa reflexão sobre a atuação da comunicação digital na visitação ao Centro Cultural, que propicia ao sujeito a experiência turística do acolhimento, apenas indica seus primeiros inputs e outputs. A caminhada, sabe-se, é longa e passa por terrenos pantanosos, íngremes, para dar corpo e voz a um conhecimento incipiente.

Há que se aprofundar nos conceitos metodológicos e em toda sua relação com o Turismo, fenômeno que a cada dia se enriquece de tentáculos. Contudo, o "proveito científico" retirado do conhecimento do espaço pode ser considerado pelo fato de que, conhecendo a realidade e o próprio fragmento para estudo, desenham-se, formam-se "linhas de força do espaço", observando-se com mais acuidade o ponto que se quer focar (BOURDIEU, 1989, p.31). 
O Turismo, por sua interdisciplinaridade, vem ampliando seu espaço no mundo, deixando cada vez mais distante o campo puramente econômico sob o ponto de vista em que foi inicialmente notado e em que a OMT insiste em encarcerá-lo, promovendo seu encontro com o social.

Para alguns, as pesquisas que dizem respeito ao discurso [...] são uma
ocupação nem sempre séria, que mistura de maneira desordenada análises de
ordem linguística e considerações sociológicas ou psicológicas de segunda
categoria. Durante muito tempo, a solução mais cômoda consistiu em
localizar tais pesquisas nos confins das ciências da linguagem. Hoje arrisca-
se menos a manter uma tal posição, pois uma crise de identidade
generalizada afeta as partilhas disciplinares tradicionais.
(MAINGUENEAU, 2007, p. 13)

Pode-se inferir, com isso, que também as pesquisas correlatas à cultura e ao próprio Turismo nem sempre são consideradas ocupações "sérias". Os motivos seriam os mesmos expostos por Maingueneau para as análises relacionadas ao discurso: sua interdisciplinaridade babélica, heterogênea e instável, decididamente de ordem social, que muitas vezes necessita fugir à doxa, em função de seu dinâmico caráter. Adotaria o CCBB uma linguagem específica voltada para a acolhida do cidadão?

\subsection{Análise do discurso - um caminho}

A linguagem e seu funcionamento vêm sendo estudados desde Ferdinand de Saussure, cujas postulações teóricas estabeleceram o objeto da Linguística. Era o início da descrição do conjunto de regras da comunicação. As remissões do linguista e filósofo genebrino revolucionaram esse campo de pensamento ao instituir classificações para a língua e a fala, os signos ou unidades significativas, o significante e o significado. É assim que Helena Brandão inicia seu livro Introdução à análise do discurso (2012).

A autora brasileira esclarece que Saussure estabeleceu uma dicotomia entre a língua, sistema abstrato e ideal, potencial, e a fala, "ato linguístico material e concreto" - ou seja, "o uso que cada indivíduo faz da língua" (BRANDÃO, 2012, p.108). Para Saussure, língua e fala não podem ser excluídos da linguagem, uma vez que esta "só existe como atividade" (op.cit.).

Estudos avançaram, tendo como um desses expoentes Mikhail Bakhtin, ao tratar e conceber "a língua como algo concreto, fruto da manifestação individual de cada falante" (op.cit.). Desse modo, ele valorizou não somente a fala, mas o lugar de fala, a 
intencionalidade. Em comum, ambos - Saussure e Bakhtin - concebiam a língua como um fato social, cuja existência se fundamenta nas necessidades de comunicação.

O reconhecimento de uma estrutura formal perpassada por um pressuposto da língua não existir por si mesma, provoca o surgimento de estudos que passam a encarar a linguagem não mais como uma entidade abstrata, mas um lugar onde se dá a manifestação concreta do subjetivo e do social. (BARROSO, 2008, p.78)

E é na condição de "antípoda de Saussure" (RIBEIRO, 2006) que o russo buscou estudar seu objeto, a linguagem, a qual está em constante processo, não se submetendo, como a língua, na linguística saussuriana, "a uma forma fixa e imutável” (op.cit.).

[...] para Saussure, é indispensável partir da língua como sistema de formas cuja identidade se refira a uma norma e esclarecer todos os fatos de linguagem com referência a suas formas estáveis e autônomas (autoregulamentadas). (BAKHTIN, 2009, p.89)

Bakhtin destaca a tese fundamental de Saussure: "a língua se opõe à fala como o social ao individual. A fala é, assim, absolutamente individual." (op. cit.).

[...] Para Saussure, um signo é uma relação entre um significante (um som, uma imagem acústica ou um grafema) e um significado (um conceito). Para Bakhtin, o significado é uma impossibilidade teórica. Um signo, aceitando-o provisoriamente, não tem um significado, mas receberá tantas significações quantas forem as situações reais em que venha a ser usado por usuários social e historicamente localizados. Em uso, a língua é muito diferente do seu modelo teórico. Para a linguística um signo tem um significado. Sabemos entretanto que, ao falar, nós estamos diariamente modificando, acrescentando, excluindo, torcendo os significados codificados pela língua. (RIBEIRO, 2006)

Bakhtin ainda insere em suas considerações o enunciado enquanto realidade da linguagem e percebe nele um elemento importante: "a presença de um enunciador (quem fala, quem escreve) e de um receptor (quem ouve, quem lê)" (op.cit.). Em uma análise marxista da linguagem, aponta a palavra como signo linguístico e ideológico por excelência, além de vivo, dinâmico e dialético.

$\mathrm{Na}$ realidade, o locutor serve-se da língua para suas necessidades enunciativas concretas (para o locutor, a construção da língua está orientada no sentido da enunciação da fala). Trata-se, para ele, de utilizar as formas normativas [...] num dado contexto concreto. Para ele, o centro de gravidade da língua não reside na conformidade à norma da forma utilizada, mas na nova significação que essa forma linguística adquire no contexto. [...] 
Mas o locutor também deve levar em consideração o ponto de vista do receptor. Seria aqui que a norma linguística entraria em jogo? Não, também não é exatamente assim. É impossível reduzir-se o ato de descodificação ao reconhecimento de uma forma linguística utilizada pelo locutor como forma familiar, conhecida - modo como reconhecemos, por exemplo, um sinal ao qual não estamos suficientemente habituados ou uma forma de uma língua que conhecemos mal. Não; o essencial na tarefa de descodificação não consiste em reconhecer a forma utilizada, mas compreendê-la num contexto concreto preciso, compreender sua significação numa enunciação particular. [...]. (BAKHTIN, 2009, p.95-96)

Tanto aquele que fala quanto aquele que recebe a mensagem integram as análises de Bakhtin. O estudioso identifica a importância da interação verbal e do interlocutor nas relações de comunicação. Para ele, o interlocutus não é um elemento passivo na constituição do significado.

É para comunicar a si mesmo como lugar de visitação e de acolhimento para o turista que o Centro Cultural Banco do Brasil Brasília (CCBB DF) utiliza como ferramentas os textos inseridos na internet, no site (www.bb.com.br/cultura) e no Facebook (www.facebook.com/ccbb.brasilia), dentre outros recursos. Em todos esses canais, observa-se o discurso do Banco a serviço do convite, do acolhimento ao outro - público visitante - que, como receptor, tanto pode atender a esse chamado quanto a ele renunciar.

Toda hospitalidade começa, portanto, com a língua, na própria língua, mais precisamente nessa oscilação turva, nunca pura, entre linguagem e língua, zona de contato e de contaminação, e isso já seria, sem dúvida, uma interpretação possível da proposição de Lévinas, "a linguagem é a hospitalidade", frequentemente citada por Derrida, mas também deslocada e examinada com mais circunspecção, e mais inquietude, talvez.[...] (MICHAUD, 2011, p.1009)

Brandão lembra que entre a língua e a fala está o discurso, o ponto de articulação dos processos ideológicos e dos fenômenos linguísticos. E complementa: a natureza ideológica do signo linguístico passou a ser adotada pelos pesquisadores sucessores do filólogo russo sem perder de vista a integração do social ao linguístico.

Foram os formalistas russos que abriram espaço para a entrada no campo dos estudos linguísticos daquilo que se chamaria mais tarde discurso - afirmação imputada por Brandão (2012) ao professor doutor Dominique Maingueneau. Desse modo, o método teria origem na também denominada Crítica Formalista, escola que atuou entre 1910 e 1930, cujo objetivo era o estudo da linguagem poética e literária. Nesse momento, observava-se a lógica de encadeamentos, e não o texto em si. Os seguidores desses estudos foram os estruturalistas ou formalistas, que propuseram o estudo da estrutura do texto "nele mesmo e por ele mesmo", 
restringindo a uma abordagem que excluía "qualquer reflexão sobre sua exterioridade" (BRANDÃO, 2012, p. 13).

\begin{abstract}
A Análise de Discurso, como seu próprio nome indica, não trata da língua, não trata da gramática, embora todas essas coisas lhe interessem. Ela trata do discurso. E a palavra discurso, etimologicamente, tem em si a idéia de curso, de percurso, de correr por, de movimento. O discurso é assim palavra em movimento, prática de linguagem: com o estudo do discurso observa-se o homem falando. (ORLANDI, 2013, p.15)
\end{abstract}

Orlandi, assim, introduz a ideia das diferentes maneiras de se estudar a linguagem: pela língua (Linguística), pela palavra (Gramática), em si, e pelo discurso (Análise de Discurso).

\title{
5.3.1 Convergência virtual da hospitalidade
}

Na perspectiva francesa de prática escolar da explicação textual e reflexão sobre texto e história, Maingueneau apreende a relação interdiscursiva na gênese dos discursos:

[...] O discurso sempre se confunde com sua emergência histórica, com o espaço discursivo no interior do qual se constituiu, com as instituições através das quais se desenvolveu, com os isomorfismos em cuja rede ele foi envolvido. (MAINGUENEAU, 2008, p.117)

Quando se volta ao tema deste trabalho, "O CCBB como anfitrião: uma reflexão sobre o turismo e a hospitalidade a partir do discurso do Centro Cultural Banco do Brasil Brasília no site e no Facebook", depreende-se que a instituição produz, de um lado, uma apresentação em discurso direto e objetivo, como determina o texto contemporâneo, produzido para o veículo indicado. De outro, a presença da estrutura ideológica, na medida em que as redes sociais reproduzem modos de fala. Nota-se que, por detrás do convite para que o visitante seja o protagonista da experiência turística, o Banco do Brasil se materializa enquanto fomentador de cultura. Em outras palavras, a linguagem corporaliza o símbolo do Banco dentro da cultura, instituindo, assim, uma relação com o interlocutor-turista.

[...] Se a linguagem existe é que, por sob identidades e diferenças, há o fundo das continuidades, das semelhanças, das repetições, dos entrecruzamentos naturais. A semelhança, que é excluída do saber desde o começo do século XVII, constitui sempre a orla exterior da linguagem: o anel que contorna o domínio daquilo que se pode analisar, pôr em ordem e conhecer. É o murmúrio que o discurso dissipa, mas sem o qual ele não poderia falar. (FOUCAULT, 2007, p.169) 
O discurso, assim, se faz presença no social e inscreve-se na história. O processo por meio do qual se dá, entretanto, não ocorre de modo linear e organizado, no qual um fala e o outro decodifica a mensagem. É preciso perceber a existência do interdiscurso, "um espaço de trocas entre vários discursos convenientemente escolhidos” (MAINGUENEAU, 2008, p.20).

Problematizar as maneiras de ler, levar o sujeito falante ou o leitor a se colocarem questões sobre o que produzem e o que ouvem nas diferentes manifestações da linguagem. Perceber que não podemos não estar sujeitos à linguagem, a seus equívocos, sua opacidade. Saber que não há neutralidade nem mesmo no uso mais aparentemente cotidiano dos signos. A entrada no simbólico é irremediável e permanente: estamos comprometidos com os sentidos e o político.[...] (ORLANDI, 2013, p.9)

O que se verifica no discurso sobre a história do CCBB DF publicado em sua página na internet (site) são as marcas do interdiscurso e o entrecuzamento de campos de saber (op.cit.). No que tange à hospitalidade, é um convite para se visitar um local pensado para a cidade e a ela integrado, cujo sucesso é validado por uma frequência que ganha relevância internacional.

Texto 1 - E tudo começa num ponto

\section{A História}

- o CCBB Brasília localiza-se no Setor de Clubes Sul, Trecho 2 (próximo à ponte JK), no Edifício Tancredo Neves, projeto de Oscar Niemeyer, inaugurado em 1993 como sede do Centro de Formação do Banco do Brasil.

- No final da década de 1990, parte do prédio foi reformada para abrigar as instalações do CCBB Brasília, com o objetivo de inserir a capital do País no roteiro internacional dos grandes eventos e produções culturais. Com projeto paisagístico assinado por Alba Rabelo Cunha, o harmonioso conjunto arquitetônico de dois andares está pousado sobre pilotis e divide-se em módulos, cabendo ao CCBB parte do prédio principal.

- Inaugurado no dia 12 de outubro de 2000, o CCBB Brasília é o segundo museu/centro cultural mais visitado no Brasil e $043^{\circ}$ no mundo, de acordo com o ranking da publicação inglesa The Art Newspaper (abril/2013).

- O prédio possui uma área construída de aproximadamente $20.551 \mathrm{~m} 2$. O CCBB ocupa $7.000 \mathrm{~m} 2$ desse total, além de uma área externa (jardins e estacionamento) com $23.940 \mathrm{~m} 2$.

Fonte: http://culturabancodobrasil.com.br/portal/distrito-federal/ (Acessado em 14out2014, às 23h30)

Focando-se na exterioridade do texto, nota-se, em torno da ideia geral, um discurso pleno de adjetivos, autoelogios e ostensivas pretensões. É o anfitrião em seu esforço por convencer seu conviva de suas qualidades, de suas nobres origens. A opção de apresentar sua historicidade em forma de tópicos e não em prosa denota, ainda, a necessidade de se 
comunicar objetivamente aquilo a que se propõe. O discurso direto é impositivo e conduz, direciona o leitor para o viés pretendido pelo falante.

No campo minado da informação, a primeira referência é sua instalação, seu endereço: “O CCBB Brasília localiza-se no Setor de Clubes Sul, Trecho 2 (próximo à ponte JK), no Edifício Tancredo Neves", demonstrando que não se trata de um espaço qualquer, mas de um lugar gerido em um ambiente elitizado (Setor de Clubes Sul). Tal fator pode levar à exclusão de visitantes que não se sintam partícipes da região. No entanto, Magali Bessone (2011) lembra que os excluídos estão incluídos na sociedade e quando a autora evoca Saül Karsz, ainda adverte que essa condição é definida pela "posição do locutor". Assim, ao mesmo tempo, quem fala dá indicações precisas para se chegar ao local: Setor de Clubes Sul, Trecho 2, (próximo à ponte $\mathrm{JK}$ ), o que leva a intuir que o locutore objetiva fazer convergir a si o maior público possível. O leitor interessado pode, com tais dados, chegar ao local por diversos meios de transporte.

Em seguida, menciona-se a autoria do desenho arquitetônico, "projeto de Oscar Niemeyer", o mais famoso arquiteto brasileiro, também conhecido por suas criações monumentais. A informação já funciona como um convite para visitação; afinal, suas obras são referência em todo o mundo e um capítulo à parte na constituição da capital federal. A sua destinação - "inaugurado em 1993, como sede do Centro de Formação" - mostra o caráter exclusivista e restrito do prédio - naquele início da década de 1990, apenas para funcionários da instituição, indicando, ainda, uma preocupação com a capacitação, a disciplina e o aperfeiçoamento do seu corpo técnico. A propriedade "do Banco do Brasil" sela o comunicado primeiro do objeto de estudo: no recinto de construção do conhecimento - "Centro de Formação" - o domínio é de um agente financeiro.

Os talentos pertencem à indústria muito antes que esta os apresente; ou não se adaptariam tão prontamente. A constituição do público, que teoricamente e de fato favorece o sistema da indústria cultural, faz parte do sistema e não o desculpa. [...] (HORKHEIMER e ADORNO, 2011, p.185)

O segundo tópico informativo indica mudança de direcionamento na destinação do edifício, pois não havia 10 anos que seu funcionamento era restrito à formação dos empregados do BB, e já recebia nova roupagem: "No final da década de 1990, parte do prédio foi reformada para abrigar as instalações do CCBB Brasília". E a alteração não era para mais um serviço usual da empresa, agência bancária, sede de superintendência, unidade operacional ou estratégica ou diretoria. Haveria um centro promotor de cultura e, como tal, 
imbuído de conexão ideológica, manifesta pela dupla função de mecenas (BB) e proprietário das "instalações".

A reforma também não se pretendia tímida, mas grandiosa e imponente, vocacionada a "inserir a capital do País no roteiro internacional dos grandes eventos e produções culturais" sem elucidar de que forma intencionava fazê-lo. A necessidade de nominar o autor do projeto novamente aparece na próxima sentença - "Com projeto paisagístico assinado por Alba Rabelo Cunha" -, reforçando a identidade do lugar e remetendo ao poder que o Banco, como patrocinador e mentor, tinha na escolha de quem ele queria ao seu lado na construção do seu Centro - como já havia ocorrido com Niemeyer. A preocupação em estabelecer controle sobre o que edifica está presente na adjetivação e no orgulho de apresentar o espaço que ocupa: “o harmonioso conjunto arquitetônico de dois andares está pousado sobre pilotis e divide-se em módulos, cabendo ao CCBB parte do prédio principal”. O ambiente, outrora exclusivo, passava a ser público e a ele estava destinado não um canto, ou um simples pedaço, mas "parte do prédio principal", demonstrando que o CCBB nascia para se fazer presença na paisagem urbana de Brasília.

No terceiro item, uma data de inauguração emblemática: "12 de outubro de 2000". Alguns anos antes, neste mesmo dia do ano de 1989, o BB inaugurara seu primeiro Centro Cultural, o do Rio de Janeiro, no edifício que outrora abrigou a presidência da instituição. Essa também é a data de aniversário do próprio Banco do Brasil, criado por ordem de D. João VI, logo em sua chegada a então colônia, no ano de 1808. O dia é também representativo por outros dois motivos: é feriado nacional, por pretexto religioso - dia da padroeira do Brasil, Nossa Senhora Aparecida - e Dia das Crianças. Essa dupla que, aparentemente, nada tem a ver com as ambições artístico-culturais-sociais-financeiras do Centro, acaba contribuindo para com o espaço que, anualmente, prepara uma programação especial nesta data, com vistas a angariar um público partícipe e ávido por novidades em seu dia de dispensa do trabalho.

O texto ainda apresenta o CCBB como um território animado, de constante movimento, onde não há mesmice, marasmo. Localiza-se no Setor de Clubes, o que remete ao lazer - ao tempo do não trabalho, na concepção de Joffre Dumazedier, ou do ócio criativo, para Domenico De Masi; tem instalações criadas por Niemeyer - por si só chamariz de turistas observadores, amantes da arquitetura - ostentando posições de destaque no Brasil e no mundo no campo da visitação pública; e, por fim, oferece ampla área livre, disponível para passeios, piqueniques, encontros e reencontros. A ocupação do tempo livre é uma característica marcante para o desenvolvimento do turismo, por demarcar as relações sociais, 
como visto em capítulos anteriores. Em 2014, por exemplo, quase 1,5 milhão de pessoas decidiram utilizar seu tempo livre no CCBB DF.

Na sequência histórica, a confirmação de que o investimento foi produtivo. A análise apresentada é a de que a sociedade (brasiliense) recebeu, adotou o novo produto, tornando-o uma força reconhecida no Brasil e no mundo: “o CCBB Brasília é o segundo museu/centro cultural mais visitado no Brasil e o $43^{\circ}$ no mundo, de acordo com o ranking da publicação inglesa The Art Newspaper (abril/2013)". A informação não esclarece quando o Centro atingiu esse patamar, nem como se deu tal levantamento de público, nem como chegou à publicação anglo-saxônica. Tais lacunas, no entanto, permitem ao investigador observar que o CCBB vem impondo uma identidade própria, assumindo-se como sujeito e colocando-se junto à sociedade, evitando uma possível rejeição de sua identidade instituída. "É o triunfo do capital investido" (HORKHEIMER e ADORNO, 2002, p. 173). Em pouco tempo de existência, o empreendimento ganhava repercussão e destaque internacional.

Os lapsos, no entanto, remetem a outra característica a ser destacada no campo da AD, a importância do esquecimento na construção da linguagem. Para Orlandi, ao lembrar M. Pêcheux ${ }^{28}$, necessariamente, o ser humano passa por dois esquecimentos constitutivos da linguagem: Paráfrase e Polissemia. O polissêmico é um esquecimento ideológico e está na instância do inconsciente (aparentemente, quem falou foi o presidente da República, mas não foi ele, pois aquele dizer já existe). Já o parafrástico é um esquecimento da ordem da enunciação. Estamos sempre reproduzindo e ressignificando o que foi dito antes de nós (Foucault); os sentidos vêm do contexto e dependem da interpretação.

Infere-se, com isso, que a linguagem não é transparente, assim como o sentido. Para falar, o locutor esquece. Ele não fala sozinho, mas constrói o seu dizer. Aquilo que ele disse pode ser dito de diversos modos. A linguagem é polissêmica, possui muitos sentidos, e é parafrástica porque o locutor reorganiza o que já foi dito. A produção de sentidos é relacional e depende do posicionamento do autor, do leitor e da obra. Entende-se que o texto tem memória radicada tanto na do emissor quanto na do receptor.

O texto é a unidade que o analista tem diante de si e da qual ele parte. O que faz ele diante de um texto? Ele o remete imediatamente a um discurso que, por sua vez, se explicita em suas regularidades pela sua referência a uma ou outra formação discursiva que, por sua vez, ganha sentido porque deriva de

\footnotetext{
${ }^{28}$ PÊCHEUX, M. Les verités de la palice. Maspero, Paris, trad. bras. Semântica e discurso, E. Orlandi et alii, Editora da Unicamp, 1975.
} 
um jogo definido pela formação ideológica dominante naquela conjuntura. (ORLANDI, 2013, p.63)

Em ambos os casos, portanto, os sentidos dependem da interpretação. É sob esse aspecto que o terceiro tópico de $A$ história segue sob análise.

O texto acompanha a nomenclatura da edição inglesa, dando ao espaço um status diferenciado. Ele não é somente um centro cultural, mas um "museu", denominação que aumenta seu valor no universo da ressignificação. Na definição de "museu" encontrada na publicação do Comitê Brasileiro do Conselho Internacional de Museus (ICOM):

O termo "museu" tanto pode designar a instituição quanto o estabelecimento, ou o lugar geralmente concebido para realizar a seleção, o estudo e a apresentação de testemunhos materiais e imateriais do Homem e do seu meio. A forma e as funções do museu variam sensivelmente ao longo dos séculos. Seu conteúdo diversificou-se, tanto quanto a sua missão, seu modo de funcionamento ou sua administração. (DESVALLÉES e MAIRESSE, 2013, p.64)

Fato inusitado é que a notícia referente ao CCBB DF estar entre os 11 museus mais visitados do mundo foi publicada no começo do mês de abril de 2015, replicada em diversos canais (G1 DF, 2015; DANTAS/Ibram, 2015), incluindo a página do Centro no Facebook (https://www.facebook.com/ccbb.brasilia?fref=ts) e no Twitter (https://twitter.com/CCBB_DF/status/585443846248620032), em 07 de abril de 2015 e, no momento em que esta reflexão está sendo realizada, em 21 de maio de 2015, o site do Centro Cultural mantém a informação desatualizada: "Inaugurado no dia 12 de outubro de 2000, o CCBB Brasília é o segundo museu/centro cultural mais visitado no Brasil e o $43^{\circ}$ no mundo, de acordo com o ranking da publicação inglesa The Art Newspaper (abril/2013)". Na edição de 2014 da publicação inglesa, referente ao exercício de 2013, o CCBB DF havia figurado em $33^{\circ}$ lugar, ao receber 1.468 .818 visitantes ao longo daquele ano, mas sem qualquer exposição de destaque (THE ART NEWSPAPER, 2014, p. 15). Mesmo alcançando resultado positivo, o site não registrou os avanços do Centro, e os dados constantes no site ainda eram os da edição de 2013, referente à programação de mostras de artes plásticas ocorridas em 2012.

Em nova consulta, em período que transcende o selecionado para a análise deste trabalho, o trecho havia sido alterado para:

Texto 2 - Entre os mais visitados

- Inaugurado no dia 12 de outubro de 2000, o CCBB Brasilia é a terceira instituição cultural mais visitada no Brasil e a $38^{\circ}$ no mundo, de acordo com o ranking da publicação inglesa The Art Newspaper (abril/2014).

Fonte: http://culturabancodobrasil.com.br/portal/distrito-federal/ (Acessado em 24out2015, às 23h40) 
A informação, ainda que com considerável atraso, foi atualizada. No entanto, apresenta erro na data da publicação, induzindo o leitor a buscar a informação na publicação de 2014, quando a correta é abril/2015. Como anotado no Capítulo 4, na informação mediática, a notícia é "parte importante, mas não sua totalidade" (MARTINO, 2012). Não se encontra outra justificativa, senão o tratamento relapso para o informe. Além dos funcionários concursados, responsáveis pela área de comunicação, há uma agência contratada para cuidar das mídias digitais. Infere-se, com isso, que há preocupação em manter em dia a página da programação, sendo esta atualizada mensalmente, deixando de lado as consideradas fixas. Mas, por que deixar de atualizar um de seus principais canais de comunicação, com uma informação favorável em seu histórico? Uma possível justificativa remete-se ao período de mudanças internas dentro da estrutura do CCBB, iniciado em meados de 2013, com a criação da Divisão de Marketing Cultural, que promoveu ajustes nas equipes dos centros, como visto no Capítulo 2.

O quarto e último tópico da historicidade demonstra a monumentalidade, a imponência do ambiente: "O prédio possui uma área construída de aproximadamente $20.551 \mathrm{~m} 2$. O CCBB ocupa $7.000 \mathrm{~m} 2$ desse total, além de uma área externa (jardins e estacionamento) com 23.940m2." A necessidade de apresentar a dimensão espacial é tão premente que a norma culta da Língua Portuguesa é esquecida na grafia " $\mathrm{m}^{2}$ ". É nesse território que o Banco do Brasil exerce seu domínio no campo da programação, ao oferecer ao visitante a oportunidade de acompanhar exposições e espetáculos inéditos, de renomados artistas, possibilitando a troca de ideias - por meio da promoção de palestras - e do seu programa educativo, o qual retoma o caráter de formação que, desde o início, caracteriza o espaço.

Por meio da programação e do acolhimento, o CCBB DF conquista os visitantes e ganha anima: "Há alma quando há paixão das gentes pelo lugar." (YÁZIGI, 2001, p. 24). Antes, porém, já o faz por meio da linguagem, lugar da constituição da subjetividade e no qual o sujeito ocupa posição privilegiada, pois se encontra no campo discursivo criado da relação com os outros (interlocutor e mensagem). O Centro se transforma, pouco a pouco, em um espaço no qual o indivíduo estabelece a prática turística, na medida em que ele próprio se torna protagonista de conhecimento e vivência de novas experiências.

Texto 3 - Informações da página - Descrição Curta 
"Seja bem-vindo à fanpage do CCBB Brasília. Aqui vamos divulgar nossa programação, trazer novidades e tirar dúvidas. Curta, compartilhe e comente!" (BANCO DO BRASIL, 2015c). Assim, com joia e alegria, em um abraço acolhedor, o Centro Cultural Banco do Brasil apresenta-se em sua página no Facebook. Mas essa é a versão "curta". Vejamos, a seguir, a "longa":

Texto 4 - Informações da página - Descrição Longa

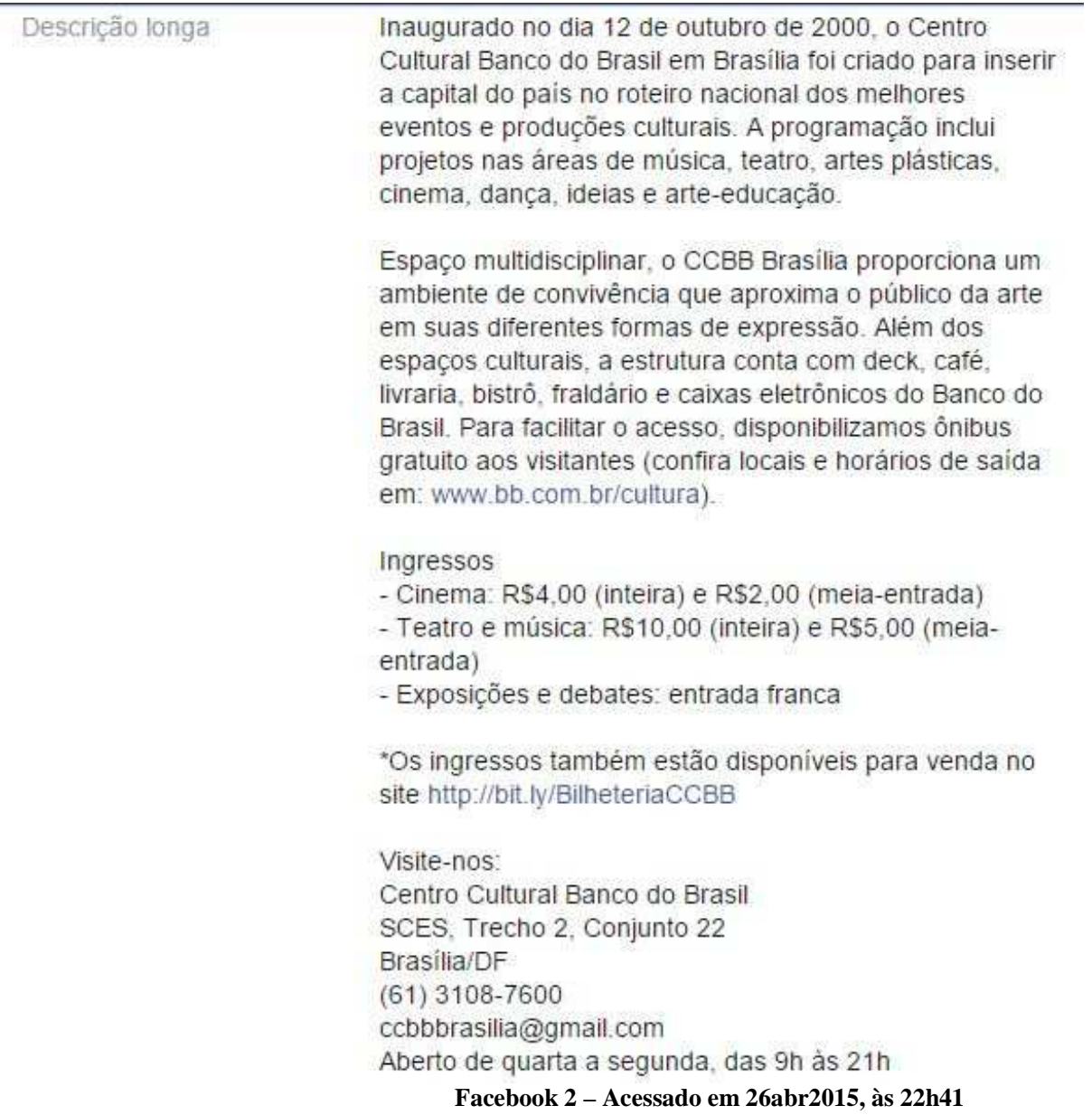

Observa-se que as duas mensagens diferem, não só em conteúdo, como também em intencionalidade. Enquanto a segunda traz informações detalhadas e em tom mais "sério" sobre o espaço, a primeira restringe-se ao limite de seu objetivo.

$\mathrm{Na}$ informação "curta", mais informal que a "longa", percebe-se que há uma proximidade com o público, a começar pela recepção: "Seja bem-vindo à fanpage do CCBB Brasília”. Nesta simples frase, nota-se a desobediência à norma culta da Língua Portuguesa, com a não inserção do itálico à palavra estrangeira "fanpage", e a calorosa acolhida a quem se presta a adentrar no recinto. Constata-se, por meio das frequentes visitas realizadas às páginas 
e comentários postados no Facebook, que a linguagem tem-se modificado para atender as práticas sociais naturalizadas por meio da língua, como visto neste capítulo, com a escrita sendo espelho de como as pessoas se correspondem e se relacionam. Assim, sem se preocupar com a forma da grafia, o enunciado segue proferindo o objetivo da página: "Aqui vamos divulgar nossa programação, trazer novidades e tirar dúvidas”. Com isso, o leitor/visitante, tendo sido acolhido, logo ao chegar, ainda recebe a preciosa informação de que ali obterá todas as respostas às suas possíveis perguntas. Novo convite encerra a resumida apresentação: "Curta, compartilhe e comente!" Os três verbos, conjugados na terceira pessoa do modo Imperativo e na forma Afirmativa, exprimem pedido ou ordem - a interpretação a ser dada depende do leitor. O foco, entretanto, é o mesmo: a participação do visitante, do fã, mas sempre com proeminência do Banco, em seu manifesto poder de provedor da informação e de anfitrião, a quem compete valorizar o visitante, como estratégia mercadológica (CAMARGO, 2011). À visita, cabe seguir, divulgar e apreciar, caso atenda ao conclame do hospedador.

Já a apresentação "longa" do CCBB DF na página do Facebook traz uma síntese de sua história, de sua programação, de seus espaços, conveniências e facilidades. O post mantém relação com a página "A história”, publicada no sítio eletrônico, ao mesmo tempo em que compartilha informações genéricas sobre a atuação do Centro. Assim, nota-se ser a inserção no site com tom mais institucional que o do Facebook. Neste, por exemplo, há claro interesse em mostrar a diversidade da programação: “inclui projetos nas áreas de música, teatro, artes plásticas, cinema, dança, ideias e arte-educação", mas, principalmente, destacar as vantagens do espaço - o que fica evidente no segundo parágrafo, cujo início dá o tom do amplo atendimento: "Espaço multidisciplinar, o CCBB Brasília proporciona um ambiente de convivência que aproxima o público da arte em suas diferentes formas de expressão." A programação constitui apenas parte do convite que o hospedador faz ao conviva. Neves et al (2006) ressaltam ser a hospitalidade tomada como uma relação social, na qual devem ser mutuamente beneficiados hospedador e visitante. Enquanto o Centro tem o público, este opta pelas diversas opções oferecidas, para além da programação e dos espaços culturais, pois há uma infraestrutura "com deck, café, livraria, bistrô, fraldário e caixas eletrônicos do Banco do Brasil". A marca do anfitrião reitera sua presença nos serviços de conveniências - as máquinas de autoatendimento. Apesar de não gerir diretamente o café, a livraria e o bistrô, o CCBB toma para si a responsabilidade de divulgar todos esses serviços mantidos em seus espaços, e angaria deles bônus e ônus. No mesmo parágrafo, anuncia a disponibilidade de transporte gratuito aos turistas, direcionando-os ao sítio eletrônico. 
Como visto com Foucart, no capítulo 2, não se trata, simplesmente de se respeitar as normas tradicionais da hospitalidade, mas de criar um universo acolhedor, posto que receber é uma arte. Essas quatro letras contêm uma valiosa extensão de acepções e a que se toma neste momento é a de Botton et al (2014, p.5), segundo a qual a arte "pode ser um instrumento, e precisamos observar melhor que espécie de instrumento é este [...]."

O texto segue com o chamado serviço geral, com informações de seus endereços físico e eletrônico, facilitando a localização do lugar, bem como comunicando os preços de ingressos praticados, a denotar uma relação de custo/benefício para o visitante, pois, além da facilidade pela aquisição pela internet, ainda informa que os custos cabem em todos os bolsos, com entradas gratuita ou a preços populares de $\mathrm{R} \$ 4,00$ ou $\mathrm{R} \$ 10,00$ (valores de inteira para os diferentes segmentos - exposição, ideias, cinema, música, artes cênicas).

Quando se observa o pronunciamento do CCBB DF, em sua apresentação biográfica, emerge a imagem-conceito do Banco do Brasil. Trata-se de um posicionamento da empresa no universo mercadológico e como ente público, relacionando e apropriando-se da linguagem da informalidade para penetrar em outros espaços, (re)criando uma identidade cultural para uma marca originalmente financeira. Contudo, como Camargo (2011, p.17) ressalta, as leis da hospitalidade abrangem tanto quem recebe quanto quem é recebido. E a retribuição esperada é o afluxo desse público.

\subsubsection{Celebrar é receber}

A década de 1950 foi determinante para a constituição da Análise do Discurso enquanto disciplina, com os trabalhos de Zellig Harris, Roman Jakobson e Émile Benveniste. Tais estudos também determinaram duas linhas de pesquisa: a norte-americana, representada por Harris, e a francesa, por Jakobson e Benveniste. De acordo com Brandão (2012), a norteamericana compreendia o discurso como uma "extensão da linguística", ao defender a transferência e a aplicação de "procedimentos de análise de unidades da língua aos enunciados", ficando à parte de qualquer reflexão sobre significação e até de considerações sócio-históricas de produção. Por esse motivo, não serão levados em consideração, neste trabalho, os estudos no âmbito norte-americano. A perspectiva da linha francesa, por seu turno, havia nascido e seguia refletindo sobre a existência de uma "crise interna da linguística", especialmente da área da semântica.

Para Deborah Schiffrin, professora no Departamento de Linguística da Georgetown University, o discurso está situado entre dois paradigmas, o funcionalista e o formalista. 
Trata-se de dois universos distintos e ao mesmo tempo complementares para o discurso, visto ser este observado tanto como "[...] uma unidade particular da linguagem (situada acima da sentença) quanto um ponto em particular (do uso da linguagem [...])",29 (SCHIFFRIN, 1994, p. 20).

De um lado, o formalista, a preocupação com o ordenamento e a articulação dos elementos textuais, sem levar em consideração os contextos comunicativos da fala; de outro, de abordagem funcionalista, o discurso pressupõe inter-relação entre linguagem e contexto. Há ainda uma terceira via proposta por Schiffrin, a do discurso como enunciados (utterances), numa tentativa de conciliar as outras duas concepções. Essa visão recupera a ideia de discurso como algo de extensão mais ampla que outras unidades da linguagem, ao mesmo tempo em que assume o enunciado como a menor parte do discurso, "[...] podemos sugerir que o discurso aparece, não como uma coleção de descontextualizadas unidades de estrutura de linguagem, mas como uma coleção de intrinsecamente contextualizadas unidades de linguagem em uso" ${ }^{, 30}$ (op.cit., p. 39).

Como as redes sociais reproduzem modos de fala, uma perspectiva a ser adotada dentro do objeto de estudo da atuação do CCBB na divulgação de seu espaço seria a de atribuir funções às situações linguísticas apresentadas nas postagens, levando-se em conta o ato comunicativo (linguagem funcionalista), a identificação das unidades mínimas que compõem o enunciado analisado (visão estruturalista/formalista), bem como a própria intertextualidade. Observa-se que, por detrás do convite para que o visitante seja o protagonista da experiência turística, o Banco do Brasil se materializa enquanto fomentador de cultura. Em outras palavras, a linguagem corporaliza o símbolo do Banco dentro da cultura, instituindo, assim, uma relação com o interlocutor-turista por meio da categoria hospitalidade.

[...] Em todas as sociedades, a humanidade tem existido em um ambiente simbólico e atuado por meio dele. Portanto, o que é historicamente específico ao novo sistema de comunicação organizado pela integração eletrônica de todos os modos de comunicação, do tipográfico ao sensorial, não é a indução à realidade virtual, mas a construção da realidade virtual. [...] Todas as realidades são comunicadas por intermédio de símbolos. E na comunicação interativa humana, independentemente do meio, todos os símbolos são, de certa forma, deslocados em relação ao sentido semântico

\footnotetext{
29 "[...] a particular unit of language (above the sentence), and a particular focus (on language use [...])". (SCHIFFRIN, 1994, p. 20).

30 "[...] we can suggest that discourse arises not as a collection of descontextualized units of language structure, but as a collection of inherently contextualized units of language use". (op.cit., p. 39).
} 
que lhes são atribuídos. De certo modo, toda realidade é percebida de maneira virtual. (CASTELLS, 2013, p.459)

Nas palavras de Manuel Castells, "a comunicação on-line, aliada à flexibilidade do texto, propicia programação de espaço/tempo ubíqua e assíncrona" (op.cit., p.114). Cabe, aqui, ressaltar que linguagem, na perspectiva discursiva, "é interação, um modo de ação social" (BRANDÃO, 2012, p.108), e, por isso, vai além de sua identificação apenas como instrumento de comunicação. Ao ser situada tanto dentro quanto fora dos mecanismos linguísticos e em campo minado, como é o sócio-histórico, ela, a linguagem, torna-se "lugar de conflito" e de "confronto ideológico" (op.cit.).

[...] A língua, no seu uso prático, é inseparável de seu conteúdo ideológico ou relativo à vida. Para se separar abstratamente a língua de seu conteúdo ideológico ou vivencial, é preciso elaborar procedimentos particulares não condicionados pelas motivações da consciência do locutor. (BAKHTIN, 2009, p.99)

$\mathrm{Na}$ era da informação da sociedade em redes, como apregoa Castells (2013), a comunicação mediada por computadores promove transformações na organização, pois a inovação tecnológica favorece a empresa a estar em sintonia com a sociedade. Assim, modelos institucionais enraizados e conservadores são levados à flexibilidade e adaptabilidade, na garantia de maior rapidez e eficiência no contato com o interlocutor.

Texto 5 - Aniversário CCBB

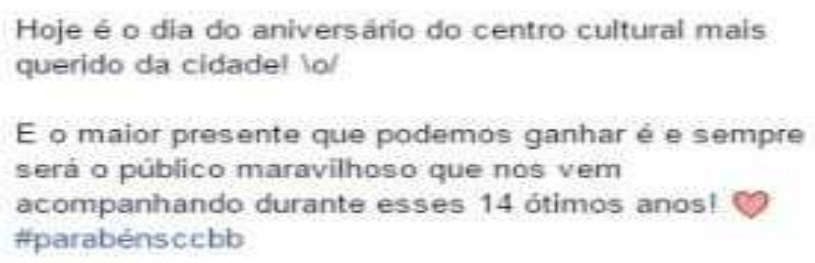

Facebook 3 - Acessado em 18out2014, às 12h51

Na mensagem acima, publicada no Facebook, de 12 de outubro de 2014, uma autohomenagem emerge, com a presunção de intitular a si mesmo, de identificar-se como o "centro mais querido da cidade". Como a linguagem, nesta plataforma, é a de informar, o tom pode soar como simplesmente festivo, uma brincadeira desinteressada, auxiliada pelos populares nas redes sociais, emoticon e emoji $i^{31}$, a ilustrar o texto. Nas referências indicadas, o

\footnotetext{
${ }^{31} \mathrm{O}$ termo emoticon, formado pela junção de duas palavras inglesas, emotion (emoção) e icon (ícone), consiste na utilização de caracteres gráficos para representar emoções humanas, como “:-)", que representa um rosto feliz. Já emoji tem origem
} 
emoticon "lo/", formado por barras representando bracinhos para cima, significa alegria, enquanto o emoji ${ }^{\top}$ representa o amor.

Resulta que, em sua materialidade, um texto (oral ou escrito) nos permite descrever e interpretar como as pessoas falam ou escrevem em diferentes contextos interacionais ou situações sociais. (SILVA, 2006, p. 167)

No segundo parágrafo, é dada uma sugestão de regalo: "E o maior presente que podemos ganhar é e sempre será o público maravilhoso que nos vem acompanhando durante esses 14 ótimos anos!”. Celebra-se, portanto, um aniversário enaltecendo seu bem maior, o público, aquele que a ele se direciona, em parte, porque sente ser ali bem-vindo, bem-quisto. Gotman ( 2011a, p.76) lembra, no contexto da narrativa da grande festa que chefes de tribos faziam para celebrar o nascimento de um filho e comunicar o fato a todos, que no "convite a um rito de passagem particularmente significativo, se lê o sentido social da hospitalidade, verdadeiro símbolo da vida de grupo.[...]". Não se trata, portanto, somente de celebrar a existência do Centro, mas de promover encontros e reencontros de familiares, amigos, conhecidos e desconhecidos. Nas palavras de Foucart (2011, p.963), "o fato de receber convidados em casa, escapa aos simples clichês da alegria de viver".

O convite é feito, na expectativa de ser atendido por quem é, na realidade, responsável pela festa: o visitante. Por outro lado, este, sentindo-se partícipe da celebração, comparece. O que se estabelece "é uma competição pela generosidade" (CAMARGO, 2011, p.18).

Ora, quem não gosta de ser convidado para uma festa de aniversário? Uma celebração, em geral, intimista, à qual apenas os mais próximos e queridos são convidados? Isso torna o conviva um ser especial frente aos mais diversos grupos e à sociedade. Ainda mais a de um lugar no qual o sujeito é comunicado e sabe, de antemão, que terá atrações de valor artístico gratuitas, segurança, pessoas sorrindo, um mundo idílico, onírico e utópico à sua frente?

Numa cena hospitaleira, quem recebe deve honrar seu visitante, organizando o espaço destinado a esse encontro, provendo o entretenimento e, ao mesmo tempo, vigiando-o. $\mathrm{O}$ conviva, por sua vez, deve honrar seu anfitrião, ocupando apenas o espaço que lhe é reservado e aceitando todas as gentilezas que receber (op.cit., p.17). Entretanto, é importante lembrar que o anfitrião é um poderoso elemento social. Nesse caso, pode-se também interpretar o convite não somente como um mero gesto de gentileza, mas como uma convocação. Afinal, sem convidados não há festa.

japonesa, sendo composto pela aglutinação de $e$ (imagem) e moji (letra), e é considerado um pictograma ou ideograma, ou seja, uma imagem que transmite a ideia de uma palavra ou frase completa. 
E quase ninguém vai sozinho à celebração da ufania: leva-se um e outro parente, amigo... Assim, o convidado torna-se, ele mesmo, um anfitrião. Tal atitude é estimulada pelo Centro.

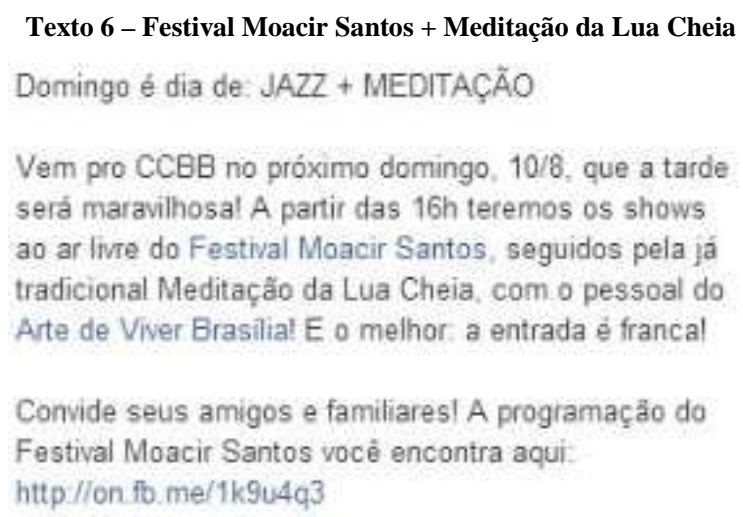

Facebook 4 - Acessado em 09ago2014, às 13 h20

Na publicação, o convite é para ouvir música e, na sequência, meditar. A união dos dois programas, distintos em suas características, traz para a análise alguns contrastes. $\mathrm{O}$ texto começa com uma espécie de título, fato raro nas chamadas do Centro no Facebook, assim como anunciar duas atrações distintas no mesmo post, com letras grafadas em maiúsculas: "Domingo é dia de: JAZZ + MEDITAÇÃO". No domingo, dia da semana geralmente reservado ao ócio, no imaginário social, o convidado pode terminar o dia, apreciando uma sonoridade reconhecida por ser destinada a gostos exigentes e ecléticos, sem a popularidade de um pop ou um rock, e em estado contemplativo. Sabe-se que o registro em maiúsculas, na comunicação na rede, serve para chamar a atenção do interlocutor para algo importante na visão do autor. Por outro lado, também é considerado grito e, consequentemente, uma forma deselegante de correspondência com o outro. Observa-se, portanto, nesse "título", a contradição entre a elegância e a serenidade da programação e a forma com a qual o texto se apresenta, de acordo com as conhecidas regras da internet. Infere-se, no entanto, que as maiúsculas foram utilizadas apenas como recurso visual, com o objetivo de destacar os eventos para públicos que vão além dos bem definidos perfis do programa - jazz para amantes do ritmo caracterizado pela improvisação e meditação para os adeptos de práticas contemplativas.

O espaço público é um retrato do grau de coesão comunitária na medida em que desempenha uma função de forte peso na eficácia dos símbolos, pois reúne em si o maior número de pessoas que partilham dos mesmos códigos. (YÁZIGI, 2001, p.202) 
A seguir, o convite direto, com uma certeza: "Vem pro CCBB no próximo domingo, 10/8, que a tarde será maravilhosa! A partir das $16 \mathrm{~h}$ teremos os shows ao ar livre do Festival Moacir Santos, seguidos pela já tradicional Meditação da Lua Cheia, com o pessoal do Arte de Viver Brasília! E o melhor: a entrada é franca!" A assertividade do prazer, garantida na primeira frase, como se vê, é válida apenas para uma parte do programa, pois a meditação só é realizada quando o satélite da Terra está bem visível, no alto do céu. A gratuidade é um chamariz à parte, seguido do conclame para que o visitante, convencido da promessa de lazer, “Convide seus amigos e familiares!" O estar entre os seus - familiares - é o primeiro senso de hospitalidade do ser humano. Com isso, o hóspede é convidado pelo anfitrião a exercer, ao mesmo tempo, os dois papeis, o de hóspede e o de anfitrião.

Mesmo o visitante mais habituado ao espaço e, consequentemente, mais aparentemente a ele ligado, ao ponto de considerá-lo como seu, sabe que é outro o dono da casa, a quem se deve respeito.

"A programação do Festival Moacir Santos você encontra aqui: http://on.fb.me/1k9u4q3." Assim termina o enunciado, com outro convite.

No espaço público da cidade contemporânea, [...] diferença e desigualdade articulam-se no processo de apropriação espacial, definindo uma acessibilidade que é, sobretudo, simbólica. Visto assim, acessibilidade e alteridade têm uma dimensão de classe evidente, que atua na territorialização (e, na maior parte dos casos, na privatização) dos espaços públicos urbanos. O conceito de habitus é sem dúvida a melhor ferramenta disponível para perceber como a dimensão de classe, uma alteridade ao mesmo tempo "desigual" e "diferente". Desse modo, a acessibilidade ao espaço público da/na cidade contemporânea é, em última instância, "hierárquica". (SERPA, 2014, p.20)

A análise do discurso (AD) nasce, tendo como base a interdisciplinaridade, sendo seu cerne constituído pela reflexão sobre a escritura em uma articulação entre a Linguística, o Marxismo e a Psicanálise. Na perspectiva de Eni Orlandi (2013), é uma disciplina que se faz, portanto, na contradição desses três campos do saber. Sobre a Linguística, o pesquisador questiona sua atenção concentrada na língua como sistema de signos e as normas gramaticais, enquanto as ciências sociais são interrogadas por excluírem a linguagem em sua materialidade.

[...] Toda vez que procuramos delimitar o objeto de pesquisa, remetê-lo a um complexo objetivo, material, compacto, bem definido e observável, nós perdemos a própria essência do objeto estudado, sua natureza semiótica e ideológica. [...] (BAKHTIN, 2009, p.72) 
Orlandi e Bakhtin nos dizem, com isso, que o objeto de estudo - no caso desta dissertação, o discurso hospitaleiro do CCBB na internet - carrega em si a dialética de forças opostas, que formam sua totalidade.

Desde o início de sua história, a hospitalidade implica não somente a oposição entre exterior/interior, inserção/exclusão, mas também seu corolário, a oposição entre nomadismo - ou mesmo errância - e sedentarismo. [...] A condição do hóspede é a de não permanecer, senão ele se torna membro, se instala no espaço. [...] É preciso falar do tempo da hospitalidade ou, antes, da brevidade dos diversos tempos, dos diversos hóspedes [...] A passagem do exterior para o interior supõe autorização ou convite, assim como proteção. A hospitalidade é rito de passagem, dádiva temporária de um espaço. (GRASSI, 2011, p.46)

Nas palavras de Grassi, "a hospitalidade é fato social, produzido por uma sociedade, num dado momento, para responder a uma situação precisa" (op.cit., p.52). Assim também a comunicação, que se dá pelo discurso. Desse modo, o Turismo conversa com a Comunicação, com a Linguística, com a Geografia etc., numa prova de que o processo turístico se dá em correspondência com o outro.

Para Orlandi, as questões referentes à linguagem requerem do cientista o deslocamento para outras áreas e teorias de conhecimento das quais as relações sociais, históricas e linguísticas são também partícipes e constitutivas. Um desses recortes apontados pela professora é a relação entre língua e discurso. No quadro teórico da AD, Orlandi destaca:

[...] nem o discurso é visto como uma liberdade em ato, totalmente sem condicionantes linguísticos ou determinações históricas, nem a língua como totalmente fechada em si mesma, sem falhas ou equívocos. [...] (ORLANDI, 2013, p. 22).

Como ressalta Brandão, e neste ponto ela concorda com Orlandi, o discurso está relacionado à "articulação dos processos ideológicos e dos fenômenos linguísticos". Na sua concepção, a discursividade depende de suas relações com o contexto sócio-histórico.

[...] O mistério que é próprio da subjetividade humana nunca poderá ser possuído como coisa ou alimento, o que não significa que não se pode, (ou deve) tentar a relação com esse mistério, procurando criar lugares de comunicação, de contato e de proximidade. Pelo contrário, só com uma relação de proximidade é possível abraçar verdadeiramente a aventura da descoberta, da realização e de superação da (sic) nós mesmos. [...] (BAPTISTA, 2002, p.157)

E a linguagem informal é uma forma efetiva de aproximação. 
Texto 7 - Dia do Trabalho

Amanhă é o Dla do Trabalio e a gente vai trabalhar com sorrisảo no rosto pra te receber. (:) Quem vai aproveitar a folguinha no \#CCBBBrasilia bota o dedo aqui. स Vem ver o tanto de coisa boa que tem: http//bit ly/CCBBnaopara

Facebook 5 - Acessado em 10mai15_11h41

Um dos feriados mais comemorados pelo trabalhador é o do dia de seu ganha-pão. Pelas cidades, diversas festividades procuram oferecer momentos de descontração para todo aquele que, de uma maneira ou de outra, ajuda no desenvolvimento da economia da nação. $\mathrm{O}$ CCBB não é diferente, e abre suas portas para seus convivas. A receptividade é explícita de imediato: "Amanhã é Dia do Trabalho e a gente vai trabalhar com sorrisão no rosto pra te receber. :)"

O sorriso é conhecido por quebrar barreiras, por acolher, com afetividade, quem chega, esboça simpatia, emoção, e colabora para o estabelecimento de relações entre as pessoas. No texto, o gesto é ainda direcionado - "pra te" - para você, leitor/público/turista. O sorriso integra a "alma do lugar":

Nossos valores são dominados pela concepção mecanorracionalista. Isto tem causado estragos de proporções angustiantes neste mundo. Não são tecnocratas ou banqueiros que nos ensinarão como alimentar a alma do lugar... Mas quem é esta senhora chamada Alma? [...] A alma está oculta, mas é perfeita. É o que um lugar qualquer tem de melhor. No fundo essa gente toda dá a entender que se não cuidarmos da alma, criaremos um vácuo, perderemos força e luz. Como então ousar nutrir o mundo com nossas ideias - ou presentear a humanidade - sem energia vital? (YÁZIGI, 2001, p.24-25)

Esse símbolo de hospitalidade e generosidade também carrega consigo seu oposto, podendo ser confundido como signo da inospitalidade, caso o visitante detecte o gesto do receptivo como, nas palavras de Luiz Octávio de Lima Camargo (2011, p.25), "riso comercial", ou seja, aquele sorriso irônico e desconfiado. Não parece ser este o mote do Centro, ao gerir uma programação que pode ser encontrada sob a égide de "CCBBnaopara", ou seja, de um lugar sempre disponível para receber e encontrar o visitante. Cabe ressaltar que, mesmo nos dias de galerias e teatros fechados, o Centro fica aberto e pode ser visitado em sua área externa.

"Quem vai aproveitar a folguinha no \#CCBBBrasília bota o dedo aqui. Ê". Por meio da alusão a uma brincadeira "bota o dedo aqui", que convida à interação, ainda que fictícia, posto que de nada adiantará o gesto, o toque na tela, o Centro aproxima-se do público. A escolha de deslocar-se é dele, do visitante, que é convidado, ainda, a conhecer a programação 
oferecida: "Vem ver o tanto de coisa boa que tem: http://bit.ly/CCBBnaopara". Em três frases, quatro expressões informais - "sorrisão", "folguinha", "bota o dedo aqui" e "o tanto de coisa boa que tem" - ajudam na criação de vínculos com o convidado. Por outro lado, uma vez dominante, o domínio se mostra na utilização do verbo no imperativo afirmativo "Vem", ao invés do convidativo conjuntivo, o qual expressa dúvida, "Venha".

E não se deve esquecer a intrínseca ligação entre trabalho e turismo. Cabe lembrar estudiosos como Urry (1996), Boyer (2003) e Krippendorf (2003), os quais apontam que o desenvolvimento das atividades turísticas a partir do século XX tem sido impulsionado pela mudança de hábitos de consumo nas sociedades contemporâneas. As pessoas adquirem folgas e férias pagas, utilizando esse tempo livre em lazer, seja por meio de viagem a curta ou longa distância, seja no entorno de onde reside. Esses prazeres tornaram-se necessidade de primeira grandeza para os trabalhadores assalariados da era pós-moderna. Assim, nada como ser recebido em um espaço, por outros trabalhadores assalariados, "com sorrisão no rosto".

Como assegura Hannah Arendt, temos, como humanos, uma condição de existência construída por labor, trabalho e ação. É nossa condição humana, que nos coloca em outro patamar, o de autores do mundo que nos cerca.

Texto 8 - Terceiro museu mais visitado do Brasil

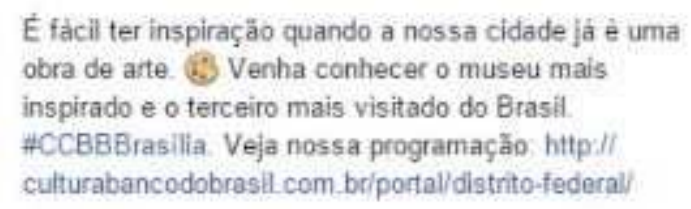

Facebook 6 - Acessado em 29abr15_23h00

No post acima, o CCBB DF invoca o imaginário para celebrar a capital federal e sua relevância turística, pelo seu urbanismo e arquitetura modernistas - "nossa cidade já é uma obra de arte". E convida o público para "conhecer o museu mais inspirado e o terceiro mais visitado no Brasil". Neste chamado autoelogioso, de dúbia informação, a identidade é colocada em xeque, uma vez que "inspiração" não condiz com a condução formal do espaço cultural, coordenado por uma instituição financeira e sujeita a normativos, como o edital de seleção de projetos e o eixo curatorial que norteia a programação.

O imaginário social torna-se inteligível e comunicável através da produção dos "discursos" nos quais e pelos quais se efectua a reunião das representações colectivas numa linguagem. Os signos investidos pelo imaginário correspondem a outros tantos símbolos. E assim que os 
imaginários sociais assentam num simbolismo que é, simultaneamente, obra e instrumento. (CASTORIADIS apud BACZKO, 1985, p.311)

Outro ponto é o convite, destinado a quem ainda não conhece aquele que conquistou o terceiro posto dentre os mais visitados do Brasil. Logo, a quem se destina esse chamado, que parece importar-se mais em convocar novos visitantes que manter seu público cativo? E ainda, por ser chamado de museu pela publicação inglesa, ele também passa a se considerar um, sem que (ainda) tenha acervo para tal.

Não se é turista o tempo todo. O turismo deve ser encarado como momento da vida; avaliado em seu espaço de tempo. Ele é ramo de uma categoria mais abrangente: o lazer, que vem sendo sonhado como ideal de civilização, desde os filósofos gregos até Trotsky. Embora boa parte da população seja turista em algum momento, pretende-se que todo turista seja um imbecil, incapaz de qualquer crítica e de ser enganado pelos pôsteres. Nesse sentido, a reconstrução do lugar entra no difícil dilema de escolher entre cair na mesmice da globalização ou de buscar um caminho condizente com o diálogo, com raízes territoriais e culturais.[...] (YÁZIGI, 2001, p.19)

Contraponto da cidade, do espaço urbano, a complexidade do turismo se estabelece justamente dessa trama. A ideia é sair do cotidiano, coberto de subjetividades, porque é o sujeito/visitante quem pratica, é recebido e recebe. Há, ainda, uma relação com esse espaço, que sempre vai estar no campo da expectativa, da motivação desse mesmo sujeito, de uma busca pela estética, posto que a forma como ele vai se relacionar com esse lugar, com aquela cultura ou experiência turística estará sustentada pela maneira como ele mesmo se relaciona com o prazer. Então, para alguns, o prazer é o turismo de aventura, para outros, o cultural, e assim por diante.

\subsubsection{Lugar de fala}

E, assim, abrem-se as chaves para a abordagem de duas vertentes que vão influenciar a Análise de Discurso (AD) de corrente francesa: ideologia, na perspectiva de Louis Althusser (1918-1990), e discurso, sob a concepção de Michel Foucault (1926-1984). Antes de trazer algumas referências de Althusser sobre o tema, Brandão adverte que o termo ideologia possui, ainda hoje, para os estudiosos, "uma noção confusa e controversa". E segue seu raciocínio, apresentando a abordagem de Karl Marx sobre o tema, de quem Althusser é tributário. Em sua elaboração crítica ao sistema capitalista, o autor de "O capital" emprega o termo com carga semântica negativa. Marx toma como base para suas formulações apenas dados possíveis de serem verificados empiricamente e identifica a existência da separação entre trabalho 
intelectual e trabalho material. Para ele, a ideologia é um instrumento de dominação das classes dominantes, que determina como uma sociedade deve pensar, sentir, agir etc. Com suas formulações, o pai do Marxismo ainda influencia diversas áreas do saber humano, como Sociologia, Economia e História.

Essa ideologia, que do ponto de vista de Marx é percebida como consciência falsa e não dotada de história ou memória, é, em parte, compartilhada por Althusser. O filósofo francês adverte, porém, que, mesmo ilusória, ela [a ideologia] se refere à realidade - para tanto, basta interpretá-la.

A iniciativa do Banco do Brasil em abrir centros culturais se inscreve [...] no contexto de mudanças que ao longo das últimas décadas vem sendo objeto de estudos no campo das ciências humanas e sociais. As análises produzidas tratam do surgimento de um novo cenário socioeconômico e cultural, característico do processo de acirramento ou de mutação do capitalismo. [...] (VIEIRA, 2006, p.2).

O espaço serve ao poder institucional para homogeneizar (SERPA, 2004). Nesse sentido, observa-se que o CCBB pauta a cultura no Distrito Federal, ao apresentar um recorte para o campo da arte. Em seu discurso, deixa claro que a programação oferecida é representativa e de importância tanto para o universo artístico quanto para o público visitante. E que esse é sempre bem-vindo aos seus espaços - o virtual e o físico, como no post a seguir.

Texto 9 - A experiência da arte - série arte para crianças

\title{
sobre a mostra
}

\begin{abstract}
"A Experiência da arte - Série Arte para Crianças" traz obras inéditas de destacados artistas da cena contemporânea, como Ernesto Neto, Paula Trope e Vik Muniz. A exposiçāo interativa apresenta um importante recorte da produção brasileira, mostrando diferentes gerações e expressões artísticas, tudo desenvolvido para o público infantil. A ideia que norteia a exposição parte do conceito de que a infância contém as condiçōes ideais para o usufruto pleno da arte, sem barreiras ou preconceitos.
\end{abstract}

Curadoria: Evandro Salles

Artistas: Paula Trope, Ernesto Neto, Cildo Meireles, Vik Muniz, Waltercio Caldas, Wlademir Dias-Pino e Eduardo Coimbra

Fonte: http://culturabancodobrasil.com.br/portal/experiencia-da-arte-serie-arte-para-criancas/ (Acessado em 18out 2014, às 21h36)

No informe publicado no site, a mostra A experiência da arte - série arte para crianças exibida no CCBB DF de 24 de maio a 11 de agosto de 2014, portanto, no período em que o Brasil recebia a Copa do Mundo de Futebol, enaltecia a arte brasileira e evocava a criança dentro de cada indivíduo. A chamada, porém, apresenta-se dúbia. Tendo como 
público-alvo as crianças, o texto em nenhum momento faz concessão e se volta para essa geração, apesar de "tudo" ser "desenvolvido para o público infantil”. O tom mantém o padrão formal da informação divulgada no site, ao contrário da linguagem mais livre encontrada nos posts do Facebook.

"A exposição interativa apresenta um importante recorte da produção brasileira, mostrando diferentes gerações e expressões artísticas, tudo desenvolvido para o público infantil”, informa. No discurso, o público é compelido a aceitar que os artistas selecionados são de diferentes gerações (etárias, artísticas?), posto não haver nenhuma especificação ou justificativa para além dos nomes elencados na primeira frase e, posteriormente, na reduzida ficha técnica. Apreende o significado do "recorte" e das "gerações" apenas pessoas que acompanham de modo mais ou menos próximo o universo das artes visuais. É o CCBB quem garante a qualidade do que o turista - e especificamente o mirim - apreciará.

As constantes mudanças que atingem a sociedade pós-moderna estão além dos assuntos de inovação tecnológica, dos processos administrativos, das ações de marketing e da modernização das cidades. Trata-se de mudanças no próprio perfil dos viajantes e das relações dele com o meio ambiente, com os outros turistas e com os anfitriões, valorizando o contato interpessoal e enfatizando mais os serviços do que os produtos em si.

A aceitação desta simples definição muda nossas atitudes e nosso comportamento, pois a comunicação não é concordância, mas sim, compreensão. [...] (NEVES e ALEXANDRE, 2006, p.7)

Uma criança não vai sozinha ao espaço, ela sempre está acompanhada dos pais, professores ou outro responsável. É, assim, um convidado que, necessariamente, leva outro consigo - apesar de, na prática, ocorrer o contrário. Mas como compreender a frase final: "A ideia que norteia a exposição parte do conceito de que a infância contém as condições ideais para o usufruto pleno da arte, sem barreiras ou preconceitos"? Nesse contexto, os elementos textuais parecem excluir o adulto e sua capacidade de abstração. Desse modo, na tentativa de privilegiar o olhar desprovido de pré-julgamento e de ideias pré-concebidas (o da criança), e homogeneizar o público, acaba criando um comunicado confuso, para um público-alvo amplo, que se torna acéfalo pelo teor da mensagem, a qual parece ter sido retirada do projeto, do conceitual da produção, e ali colocada sem se preocupar com um tratamento mais descritivo e informativo, como é usual das publicações no site. 
Outro ponto a ser observado é que o texto cita as "obras inéditas de destacados artistas da cena contemporânea, como Ernesto Neto, Paula Trope e Vik Muniz", mas deixa ausente o intruso Wlademir Dias-Pino, escritor e não artista plástico, como os demais. Seu livro experimental, A ave, criado em 1948 e impresso artesanalmente até 1956, deu origem a uma obra interativa, por meio da qual os visitantes manuseavam palavras retiradas das poesias de Dias-Pino para criar seus próprios poemas e frases.

[...] Todo o paradigma da acolhida é convocado: o abrigo, o refúgio, o esconderijo, chegando até ao jogo de esconde-esconde. O hóspede é, por seu turno, visto sob seus múltiplos aspectos: o convidado de honra, o convidado de marca, o hóspede familiar, o exilado, o estrangeiro, o refugiado, o ocupante, o naturalizado.

No mais das vezes, entre uma categoria e outra, as fronteiras são frágeis e permeáveis, as figuras são ambíguas e mistas: o jogo, o divertimento e a tranquinagem que acompanham desde sempre a literatura se tornam cada vez mais manifestos em nossa modernidade, permitindo-nos falar, no que diz respeito às relações textuais, de uma hospitalidade divertida. (CONSTANTINESCU, 2011, p.681)

Acima, o professor de literatura francesa remete aos diversos aspectos sob os quais um visitante é visto, do convidado de honra ao ocupante de um espaço. Nesse aspecto, pode-se inferir sobre a hospitalidade oferecida pelo CCBB e seu componente ideológico referencial, posto que na condição de anfitrião encontra-se um ente financeiro.

Em outra ponta dessa discussão está Michel Foucault. Embora tenha sido filósofo e não linguista, o teórico influenciou e continua a inspirar pesquisadores dos mais diversos ramos ao apregoar que a construção de um objeto do saber deve levar o investigador a interrogar o próprio discurso sobre suas regras de formação. Uma afirmativa a considerar, neste momento, é sua defesa sobre a existência de processos internos de controle e delimitação do discurso, no qual determina: o autor é a unidade e a origem das significações do discurso, o núcleo de sua coerência.

[...] $\mathrm{O}$ autor, não entendido, é claro, como o indivíduo falante que pronunciou ou escreveu um texto, mas o autor como princípio de agrupamento do discurso, como unidade e origem de suas significações, como foco de sua coerência. [...] (FOUCAULT, 2013, p. 25).

Para Foucault, o autor é responsável pelo texto que produz, mas ele limita sua função a um quadro restrito e, consequentemente, privilegiado, de produtor original da linguagem. 
Nesse contexto, Orlandi se difere do mestre, pois amplia a noção de autoria para o uso corrente, enquanto função discursiva do sujeito, dessemelhante da de enunciador e de locutor.

Nessa concepção, a linguagem é o lugar da constituição da subjetividade, enquanto o sujeito ocupa posição privilegiada, pois se encontra no espaço discursivo criado da relação com os outros (interlocutor e mensagem).

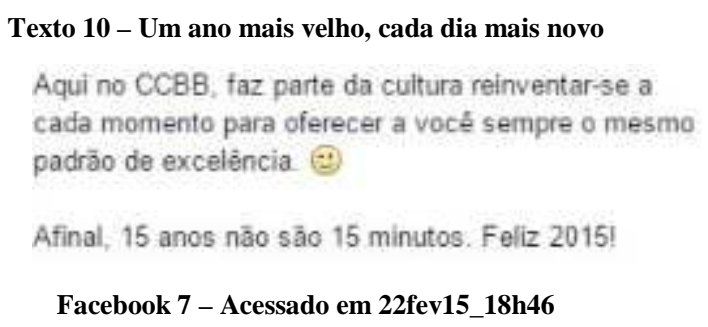

Quando se observa o pronunciamento do CCBB, emerge a imagem-conceito do Banco do Brasil. Trata-se de um posicionamento da empresa no mercado e ao seu papel de ente público, relacionando e apropriando-se da linguagem da informalidade para penetrar em outros espaços, criando uma identidade hospitaleira para uma marca originalmente financeira.

Considerando a hospitalidade como atividade social que envolve várias atitudes do núcleo receptor e dos visitantes, o ato de recepcionar virtualmente, ou seja, receber e enviar mensagens eletrônicas é um campo fértil e aberto para uma gama variada de estudos da hospitalidade, principalmente se considerar os games e o entretenimento virtual. (NEVES e ALEXANDRE, 2006, p.5)

A comunicação virtual do $\mathrm{CCBB}$ também prevê a interatividade, no intuito de promoção de projetos. Nas páginas, podem ser encontrados jogos como quizzes, nos quais o leitor responde perguntas sobre a programação e pode ou não concorrer a ingressos e catálogos; convites são feitos para se fotografar obras, espaços, tendo sua imagem compartilhada, dentre outros - conforme postagens a seguir:

Texto 11 - Kandinsky - Quiz

Se você ainda não sabe a resposta desse Quiz, tá precisando visitar a exposição \#Kandinsky CCBB $\odot$

Facebook 8 - Acessado em 02dez14_00h42 
Texto 12 - A experiência da arte - interação

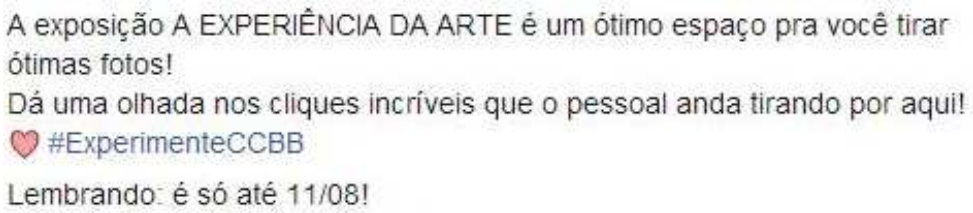

Facebook 9 - Acessado em 27jul14_08h12

Texto 13 - Beekme

Vem conhecer melhor Brasilia com o aplicativo

Beekme! ::)

Com ele você pode ver e ouvir informações sobre os pontos turisticos mais próximos, além de conferir os detalhes das obras de arte dos principais museus e pontos turísticos, incluindo o CCBB Brasilia!

Ficou curioso pra ver como isso funciona? Baixe o aplicativo e vem experimentar aqui no CCBB! É de graça! $\Theta^{3}$

Facebook 10 - Acessado em 31out14_23h18

Observa-se, com isso, que a linguagem e as atrações precisam estar conectadas ao seu público.

O modelo clássico de comunicação apresentado estabelece um contato interpessoal entre emissor e receptor na medida em que a troca da mensagem (“feedback") seja compartilhada gerando sempre uma reação do receptor. Neste tratado universal da linguagem humana, o sentido da troca de experiências está implícito nos interlocutores e o fazem através de um darreceber-retribuir constante, onde identifica-se a necessidade de correlacionar a noção da teoria da hospitalidade com o modelo tradicional da comunicação quando o emissor codifica uma mensagem para o receptor poder decodificála, este retribui conforme suas experiências criando um constante movimento de troca e relacionamentos pessoais. (NEVES e ALEXANDRE, 2006, p.8-9)

Neves et al indicam o processo corriqueiro e esperado da comunicação. No entanto, como lembra Orlandi (2013, p.21), a linguagem tanto "serve para comunicar" quanto "para não comunicar", posto que "as relações de linguagem são relações de sujeitos e de sentidos". Assim, "seus efeitos são múltiplos e variados". A estudiosa brasileira completa: "Daí a definição de discurso: o discurso é efeito de sentidos entre locutores." (op.cit.)

Entre fevereiro e março de 2015, o CCBB DF recebeu a montagem teatral Contrações, texto de Mike Bartlett, com direção de Grace Passô e tendo Débora Falabella e Yara de Novaes no elenco. No site, a informação manteve a linguagem informativa, de resumo do texto dramático e o serviço geral, com horários das apresentações. 
Texto 14 - Contrações - site

\section{SABANALS \\ sobre a peça}

No espaço de um escritório, em uma grande corporação, a funcionária Emma (Débora

Falabella) é convocada por sua gerente (Yara de Novaes), que lhe pede para ler em voz alta uma cláusula contratual que proíbe aos funcionários qualquer relação sentimental ou sexual com outro empregado da empresa. Nos encontros seguintes, a gerente, exorbitando seus poderes, exibe diferentes facetas para manipular Emma. A fim de manter o emprego, a funcionária se submete ao assédio moral de sua superior, o que expõe a sua privacidade e causa danos à sua vida particular.

\section{PROGRAMAÇÃO}

Sexta $-21 \mathrm{~h}$

Sábado - $18 \mathrm{~h} 30$ e $21 \mathrm{~h}$

Domingo - $18 \mathrm{~h}$

Fonte: http://culturabancodobrasil.com.br/portal/contracoes-4/ (Acessado em 08mar2015, às 22h23)

Já uma das postagens no Facebook introduz na cena o provável espectador e, portanto, visitante, convidando-o a decodificar a mensagem:

\begin{abstract}
Texto 15 - Contrações - Facebook
Não venha só por causa dos prêmios, da Yara de Novaes ou da Débora Falabella. Venha porque é sobre você. Contrações, de Mike Bartlett, de 20 de fevereiro a 15 de março. Garanta seu ingresso. Pensou cultura, pensou \#CCBBBrasilia.
\end{abstract}

Facebook 11 - Acessado em 22fev15_16h34

O convite é enviesado e parte da premissa de que o público conhece a história da peça e todo o seu passado de sucesso - a montagem havia estreado um ano antes, no CCBB SP, tendo já percorrido os demais CCBBs e angariado diversas premiações para as duas atrizes. "Não venha só por causa dos prêmios, da Yara de Novaes ou da Débora Falabella" - inicia, assim, com uma negativa que, ao mesmo tempo, contém informações - as premiações recebidas pela montagem. É um outro modo de dizer: você tem diversos motivos para ver esta montagem teatral.

A frase seguinte - "Venha porque é sobre você" - joga diretamente no colo do público a opção de encarar um espetáculo que o CCBB afirma ser sobre você. O leitor, caso não tenha visto nenhuma publicação relatando a história, o contexto do espetáculo, como a inserida no 
site do CCBB ou outras postagens no Facebook ou até mesmo as informações dos jornais, ficará apenas com essa indicação. Fala o quê sobre você/mim?

A seguir, os nomes da montagem e do autor, além do período da temporada e um comando: "Contrações, de Mike Bartlett, de 20 de fevereiro a 15 de março. Garanta seu ingresso." A direção, grande responsável pelo resultado deste e de qualquer espetáculo, não existe na mensagem, foi omitida. Afinal, como visto anteriormente, a linguagem é polissêmica (possui muitos sentidos) e parafrástica (o locutor reorganiza o que já foi dito). As frases, agrupadas, deixam a mensagem confusa para o leitor, pois infere-se que haja uma mesma situação de memória radicada tanto na mente do emissor quanto na do receptor. Como lembra Orlandi,

\begin{abstract}
A memória [...] tem suas características, quando pensada em relação ao discurso. E, nessa perspectiva, ela é tratada como interdiscurso. Este é definido como aquilo que fala antes, em outro lugar, independentemente. $\mathrm{Ou}$ seja, é o que chamamos memória discursiva: o saber discursivo que torna possível todo dizer e que retorna sob a forma do pre-construído, do já-dito que está na base do dizível, sustentando cada tomada da palavra. [...] (ORLANDI, 2013, p.31)
\end{abstract}

"Pensou cultura, pensou \#CCBBBrasília", finaliza o enunciado, com a marcação da territorialidade, com o orgulho de ser um centro a abrigar produções de destaque no cenário artístico. Afinal, a natureza da linguagem é ser social.

Em seu discurso, implicitamente, o Centro coloca-se como um lugar a ser visitado, extrapolando sua função de polo atrativo, pois trata-se de espaço dotado de infraestrutura com programação qualificada, sedimentado no pilar da interseção informação-cultura-turismoconsumo-turista. Ao mesmo tempo, mantém vínculo com seu cliente, ao oferecer descontos para os que possuem conta bancária na instituição, convites para pré-estreias, dentre outras ações de relacionamento de marketing, além de disponibilizar ao público em geral sem, assim, discriminar clientes de não-clientes (os possíveis futuros clientes), uma programação de interesse para a sociedade e a preços acessíveis.

$\mathrm{Na}$ análise do discurso de perspectiva francesa, marxista, tudo é minucioso, porque nela a linguagem é material, na qual se busca entender como a fala se constrói, como se fala sobre nós mesmos, falantes da língua, sobre sua condição de produção, sem interferência pois não cabe ao analista produzir intervenção. Em contraposição, como visto, há a vertente norte-americana, cujo representante, Zellig Harris, traz em si uma perspectiva mais intervencionista. Uma terceira via é a vertente anglo-saxã, representada por Michael Halliday, segundo a qual o discurso está relacionado à interação oral, e mais recentemente por Norman 
Fairclough e sua Análise de Discurso Crítica (ADC). Em qualquer dos casos, porém, não existe o óbvio - de modo imperativo - para o analista.

A vertente britânica da análise de discurso propõe uma abordagem crítica de problemas sociais que envolvem linguagem. E uma base importante foi estabelecida em 1973, quando Halliday, com sua Linguística Sistêmico-Funcional (LSF), começava a fortalecer a proposta de uma teoria linguística da linguagem, não apenas em sua descrição, mas também na demonstração de como se interpreta um texto. $\mathrm{O}$ autor defendia a multiplicidade funcional da linguagem, pois via como ela se refletia na organização interna da língua, em sua "exterioridade" (o funcionamento da língua, para quê ela serve) e "interioridade" (as necessidades da língua reveladas pela estrutura da linguística - gramática). Para Halliday, a linguagem possui três funções: Ideacional, que implica transitividade (a sentença como processo); Interpessoal, na qual a oração é tida como ato de fala; e Textual, a qual consiste na construção e na organização dos textos e envolve tema e informação (a sentença como mensagem) (SILVA, 2013). Essas funções argumentativas e comunicativas da linguagem estão também conectadas aos enunciados, considerados por Halliday como porções do discurso em sentido completo, são unidades de informação, com as quais os analistas de discurso devem se preocupar. Na dimensão textual, a unidade básica de análise é o texto, composto por vários segmentos. Halliday propõe focar no significado da linguagem e na oração como processo, como ato de fala (interpessoal).

Texto 16 - Trágica.3

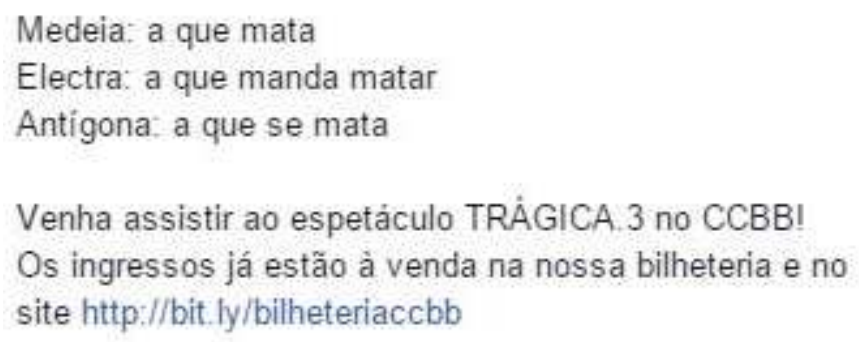

Como informa o texto do $\operatorname{site}^{32}$, o espetáculo Trágica.3 trouxe ao espectador uma releitura no formato de três peças curtas de três tragédias gregas escritas por aqueles que são considerados os "pais" do gênero e cujas protagonistas são mulheres: "Medeia", de Eurípedes, "Electra", de Ésquilo, e "Antígona", de Sófocles. As releituras são de três autores contemporâneos: o alemão Heiner Müller e os brasileiros Caio de Andrade e Francisco Carlos. Apenas a direção é assinada por um único profissional, Guilherme Leme.

\footnotetext{
${ }^{32}$ O link para o texto no site é: culturabancodobrasil.com.br/portal/trágica-3-4/
} 
Pode não ter sido intencional, mas na interseção da linguagem, o número três, ao aparecer reiteradas vezes, provoca certa curiosidade, especialmente quando se analisa um discurso. No entanto, entende-se que o chamado reproduz a concepção do projeto. Assim, não se deve imputar ao autor CCBB qualquer relação ou conotação com os números, pois corre-se o risco de sair do contexto, perdendo-se o foco do objeto.

Assim, ao observarmos a postagem acima, no Facebook, por meio da lupa de Halliday, compreende-se cada enunciado relacionado a cada uma das protagonistas como unidade de informação, como fração do discurso em sentido completo. A reescrita é sucinta, direta, apresentada em formato de lista, a caracterizar as três personagens. "Medeia: a que mata"; "Electra: a que manda matar"; "Antígona: a que se mata". O leitor, convidado a acompanhar in loco as sagas dessas três mulheres, não necessariamente precisa conhecer suas histórias originais - apesar de todas serem de fácil acesso e, de certo modo, conhecidas pela sua reprodução em filmes, por exemplo. Nem saber que o trágico, da forma como foram concebidas as obras, originalmente, tem a ver com o quadro cultural da antiga Grécia, quando a vida dos seres humanos era regida pelos deuses do Olimpo, sendo aqueles meros joguetes nas mãos destes.

O convite é para que o visitante se interesse em acompanhar seja lá qual for a trajetória dessas três criaturas ligadas ao Tânatos, à morte. "Venha assistir ao espetáculo TRÁGICA.3 no CCBB! Os ingressos já estão à venda na nossa bilheteria e no site http://bit.ly/bilheteriaccbb”. Não há informação quanto à temporada. Só saberá quem se interessar em adquirir os ingressos ou se remeter ao site do Centro. A falta dessa informação, pode-se inferir, deve-se ao fato de a postagem datar do dia 03 de novembro de 2014, quando a montagem já estava em cartaz no CCBB - as apresentações haviam começado três dias antes, no dia 31 de outubro. Logo, é como se o leitor fosse um contumaz seguidor da programação do Centro, não sendo necessário reiterar aquele tipo de informação.

Uma nova abordagem para a análise do discurso foi capitaneada por Norman Fairclough, a ADC, na qual o discurso passou "a ser enfocado como prática social e a linguagem como um objeto historicamente produzido e interpretado, em termos de sua relação com estruturas de poder e ideologia" (SILVA, 2012, p. 226). Não se entende, no contexto dos discursos selecionados, algum que possa conter os critérios da ADC. No entanto, por sua relevância na prática das análises desenvolvidas nesse campo, especialmente por sua relação com a Universidade de Brasília, destaca-se que, na ADC, toda pesquisa, para ser útil, deve ser preconizada por uma prática social transformadora. No entanto, não se pode limitar a descrever os usos, mas buscar interpretá-los, bem como suas motivações linguísticas, sociais, 
culturais, históricas e ideológicas; por exemplo, por que usamos "Senhor" para homens e "Senhorita" ou "Senhora" para mulheres? O que está por trás dessa necessidade de diferenciação no contexto da sociedade?

\subsubsection{Procedimentos em processo}

Nominal e historicamente ligado ao país, o Banco do Brasil carrega consigo as marcas de seu controlador. No âmbito dos direitos individuais, lembra Vieira (2006, p.187), sua conquista ocorreu sem expressiva participação democrática, angariando para o Estado a percepção distanciada e pouco aderente aos sentimentos da coletividade.

Essa talvez seja uma das razões pela a qual (sic) o Banco do Brasil, que conseguiu lograr a imagem de instituição patrimônio dos brasileiros, não consegue ser visto como banco do povo, atributo percebido no Bradesco. Nas pesquisas desenvolvidas, a percepção do Banco do Brasil como braço do Estado mantém as camadas populares a meia distância, sem querer maior envolvimento para não estar sujeita às sanções do Estado. Tal prudência e recato em utilizar os serviços do Banco do Brasil e adentrar em seus espaços talvez seja um dos motivos pelos quais os CCBB, em função da imagem do seu patrocinador, se tornaram os equipamentos culturais de excelência para compor a paisagem de poder dos programas de enobrecimento dos centros metropolitanos brasileiros, dada o (sic) seu caráter oficial estar mais compatível com a desenvoltura dos grupos sociais que lograram "europeizarse" instrumentalmente para validar sua classificação social. (op.cit., p.188)

Apesar dessa reiterada associação do BB com a elite, observa-se que a maior instituição financeira pública do país é líder na lembrança da população na categoria Banco na premiação Top of Mind $^{33}$. O Banco do Brasil é, desde 1992, ano da primeira edição da referida premiação, o primeiro a ser lembrado pelos brasileiros (PILAGALLO, 2015). O esforço de aproximação da marca à população é contínuo e parte de publicidade e ações para ser identificado como "bom para todos" (campanha a partir de 2012), conceito que precede o posicionamento da marca como "banco de mercado com espírito público" (lançado em 2014). O CCBB, certamente, é partícipe desse reposicionamento.

[...] a lealdade se realiza com grande sucesso no campo simbólico, sem, todavia, criar elos complementares e objetivos na difusão de negócios. As afinidades eletivas se traduzem no campo da visibilidade, do retorno

\footnotetext{
${ }^{33}$ Pesquisa realizada por profissionais do instituto Datafolha, em 244 municípios brasileiros de todas as regiões do país, com 8.142 entrevistados, sendo as classes econômicas assim identificadas: 4\% A; 6\% B1; 20\% B2; 22\% C1; 24\% C2 e 25\% D/E. Dessas, $18 \%$ possuíam superior completo; $46 \%$ o ensino médio; e $36 \%$ o fundamental. Foram pesquisadas 50 categorias. A pergunta respondida pelos entrevistados foi: "Qual é a primeira marca que lhe vem à cabeça?" (FOLHA DE S.PAULO, 2015).
} 
espontâneo de mídia, e na reverência da Instituição, respeito mais associado às questões do poder e da identidade nacional. (VIEIRA, 2006, p.05)

Como sociedade de economia mista, o Banco do Brasil lança seus editais de patrocínio e cessão de espaço. Também nesse meio, a hospitalidade pode ser lida nas entrelinhas:

Texto 17 - Edital 2015/2016

Sabe aquele seu amigo artista? Que tal mostrar essa oportunidade para ele?

As inscrições para o Edital de Cultura do Banco do

Brasil estão abertas até o dia 19/09, quem sabe essa

não é a grande chance que ele precisava. Saiba mais:

hitp//bit.ly/1t713i2 (-)

Facebook 13 - Acessado em 14set14_22h33

Nela, o leitor é convidado a convidar. Em um texto redigido como se dois amigos conversassem, apela-se para a generosidade e o desprendimento do interlocutor. Quem detém o poder da fala envolve o outro com a possibilidade de ser ele, o outro, o protagonista da história, quem levará a boa-nova a um terceiro, ao "amigo artista".

$\mathrm{Na} \mathrm{AD}$, a exploração possui abordagens diversas, de apelo hermenêutico e na qual coexistem diferentes linguagens em uma única formação discursiva. Há textos, por exemplo, que parecem não ter sujeito. Retomando a formulação de Benveniste, pode-se encontrar enunciado sem enunciador? Quando se trata de textos desse tipo, com o enunciador aparentemente ausente, inexistente, ainda pode-se encontrar a fonte enunciativa - CCBB - no caso, entidade abstrata cujos membros estão autorizados a tomar a palavra. Tal enunciador assume a neutralidade, a objetividade e a imparcialidade do discurso. E deve-se ter sempre presente a assertiva de Foucault, segundo a qual o autor existe e é real, passível de identificação e de a ele serem imputadas responsabilidades.

Acolher o outro como hóspede significa que aceitamos recebê-lo em nosso território, em nossa casa, colocando à sua disposição o melhor do que somos e possuímos. Contudo, nossa casa continua a ser isso mesmo, a nossa casa. Do mesmo modo, o outro mantém a liberdade do forasteiro, continuando a seduzir-nos com sua exterioridade e seu segredo. A hospitalidade permite celebrar uma distância e, ao mesmo tempo, uma proximidade, experiência imprescindível no processo de aprendizagem humana. Portanto, é urgente transformar os espaços urbanos em lugares de hospitalidade. [...]. (BAPTISTA, 2002, p.162)

Seja no espaço virtual, seja no ambiente físico, o sujeito CCBB é aquele que fala. 


\title{
5.3.5 Espaço de penetração
}

A coerência é dada pelo contexto. E cada ordem de discurso encerra gêneros discursivos característicos que implicam em capacidade de se ver um elemento através da lupa de outro (SILVA, 2006). Ocorre que

\begin{abstract}
Algumas metáforas são tão profundamente naturalizadas no interior de uma cultura particular que as pessoas não apenas deixam de percebê-las na maior parte do tempo, como consideram extremamente difícil escapar delas no seu discurso, pensamento ou ação, mesmo quando se chama sua atenção para isso. (FAIRCLOUGH, 2001, p. 241).
\end{abstract}

Daí a importância, dentro da ADC, de se perceber os perigos que cercam a linguagem, tendo em vista as práticas sociais que estão naturalizadas. Sob esta ótica, a língua, como sistema, só tem validade se o observador descrever as funções: em quê situação aquele morfema é utilizado, qual a situação de risco? No texto inserido nas redes sociais é possível identificar como, pode-se dizer, familiar a noção de que as práticas sociais são sempre discursivas, proporcionando a percepção do contexto em que o próprio autor está envolvido e que sua mensagem será fruto de suas vivências e ideologias (SILVA, 2013). Desse modo, a própria forma da escrita vai espelhar esse processo.

\begin{abstract}
A hospitalidade é uma dádiva. Em seu célebre "Ensaio sobre a dádiva: forma e razão da troca nas sociedades arcaicas", publicado em 1923-1924, Marcel Maus descreveu o exercício das prestações e das contraprestações que regem o ciclo das trocas em sociedades "primitivas" ou "arcaicas". Trata-se do que ele designa como um fenômeno social total, porque exprime toda sorte de instituições: religiosas, jurídicas e morais, políticas e familiares, econômicas (sem falar das formas morfológicas e estéticas). A ideia é que o caráter voluntário, aparentemente livre e gratuito, da dádiva e da hospitalidade é, todavia, coagido e interessado. Decerto, aquilo que se troca não são apenas bens de consumo, coisas úteis economicamente. São, antes de tudo, cortesias, banquetes, ritos, danças, festas. [...] A obrigação de retribuir os convites sob pena de prejudicar a própria imagem cria uma coesão social num sistema de reciprocidade que antropólogos e etnólogos puseram muito bem em evidência. (MONTANDON, 2011c, p.42)
\end{abstract}

Montandon, acima, reitera o desejo de retribuição como essencial ao vínculo humano e comunga com Anne Gotman quando esta afirma que, na obra de Mauss, a hospitalidade "representa uma das prestações típicas da troca não mercantil" (GOTMAN, 2011a, p.73),

em sua sequência em três tempos: dar, receber, retribuir - o convite como oferta; a visita como hospitalidade recebida e o fato de retribuir o convite -, mais do que da hospitalidade como troca. [...] (op.cit., p.75) 
A situação do visitante em sua relação com o CCBB, também na linguagem, está intrinsecamente ligada ao acolhimento, ao contato com o outro. Nas palavras de Grassi, "hospitalidade instaurada como gesto necessário de compensação, de igualização, diante de uma evidente disparidade cívica do status dos protagonistas”. (GRASSI, 2011, p.52).

Texto 18 - “Obsessão Infinita” - Yayoi Kusama

\section{sobre a mostra}

Em seu último mês em Brasilia, a mostra que já atraiu mais de 60 mil pessoas traça a trajetória de Yayol Kusama do privado ao público.

Obsessăo Infinita é a primeira exposição apresentada no país que expressa uma pesquisa profunda sobre o trabalho de Kusama, uma das artistas mais originais e inventivas do Japão contemporâneo. Da pintura à performance, do ateliê às ruas, desde 1977 a artista vive voluntariamente em uma instituição psiquiátrica. O caráter psicológico singular e pronunciado de seu trabalho sempre foi combinado com uma generosa dose de reinvenção e inovação formal, produzindo peças que fizeram dela, com justiça, a artista viva mais celebrada do Japão.

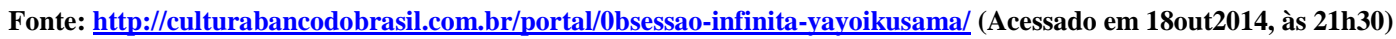

A mostra Obsessão Infinita - Yayoi Kusama ficou em cartaz de 19 de fevereiro a 28 de abril de 2014, chegando, ao final do ciclo, a contabilizar 471.730 visitantes (THE ART NEWSPAPER, 2015). Embalada pelo estrondoso sucesso da exposição no CCBB Rio Janeiro, as obras da japonesa já aterrissaram em Brasília com grande expectativa do público, que atendeu aos chamados do CCBB e a ele afluiu em massa, formando filas praticamente em todos os dias, com média diária de 7.957 pessoas (op.cit.). Desse modo, chama atenção a informação constante na publicação no site: "Em seu último mês em Brasília, a mostra que já atraiu mais de 60 mil pessoas traça a trajetória de Yayoi Kusama do privado ao público.” Ora, estima-se que naquele mês derradeiro a mostra tenha atraído bem mais que 60 mil espectadores, posto que seria praticamente impossível para o espaço receber mais de 400 mil pessoas em 28 dias. Tal constatação leva a análise a suspeitar que a postagem foi apenas parcialmente atualizada de um mês para o outro. Acredita-se que o número apresentado, “mais de 60 mil pessoas", tenha sido alcançado apenas nos 10 dias de fevereiro, tendo a informação sido publicada na edição de março e replicada na seguinte. A exemplo do que se observou na postagem sobre A história, o site apresenta considerável atraso nas atualizações.

Na sequência, o texto segue com caráter informativo e centrado na figura de quem é Kusama: "uma das artistas mais originais e inventivas do Japão contemporâneo", que "desde 
1977 [...] vive voluntariamente em uma instituição psiquiátrica", sendo a "artista viva mais celebrada do Japão". "Da pintura à performance, do ateliê às ruas", o visitante pode acompanhar um apanhado da "primeira exposição apresentada no país que expressa uma pesquisa profunda sobre o trabalho de Kusama”. No discurso, a valorização do público, que, portanto, tem o privilégio de apreciar uma mostra inédita e criteriosa, de uma artista que desperta curiosidade e fantasia.

Essa valorização do visitante foi mais visível e incisiva um ano depois, na publicação do Facebook, ao se constatar que o afluxo do público alçou a exposição de Kusama, no CCBB Brasília, ao posto de a $11^{\text {a }}$ mostra mais vista do globo. Percebe-se, no tom de celebração, a alegria do autor que, estranhamente, enaltece primeiramente "Yayoi Kusama e \#CCBBrasília”, os quais "deram um match incrível e resultaram em uma das exposições mais visitadas do mundo". É o lugar da fala, é o poder da marca mostrando sua força; afinal, sem as obras da artista não haveria a possibilidade de o Centro realizar a mostra. Daí, passa-se à informação do ranking e só por último o público visitante, a grande estrela, no caso, é agraciada. "Agradecemos a todos os 471.730 mil (sic) visitantes que passaram por aqui. Devemos isso a cada um de vocês $\bigcirc$ Muito obrigado $\nabla "$.

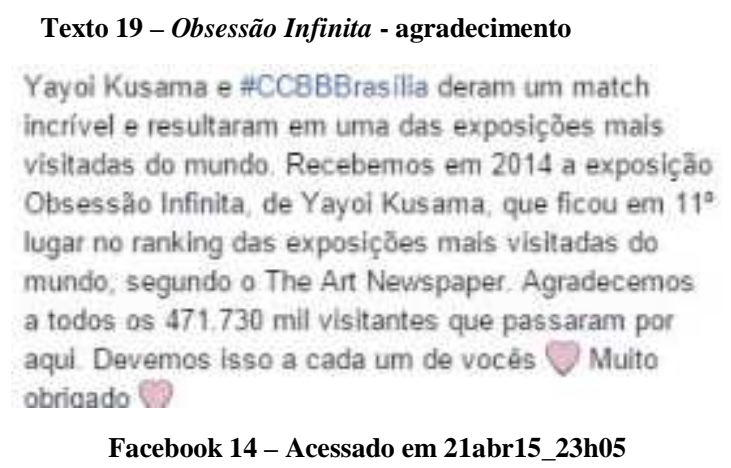

Nascida da interdisciplinaridade, a linguagem apresenta-se como um fenômeno a ser estudado, não só em relação ao seu sistema interno, enquanto formação linguística, mas também enquanto formação ideológica. Não há chave nem verdades ocultas, há método e gestos de interpretação.

O CCBB, na programação, foca na pluralidade temática, no ineditismo e na relevância cultural, possibilitando o acesso à arte e à cultura aos mais diversos segmentos da sociedade. Com isso, a linguagem empregada não segrega públicos, uma vez que na internet as fronteiras das classes sociais são abolidas. A informação divulgada tanto reproduz a oferta de lazer e 
entretenimento oferecidos pelo destino quanto oferece ao leitor/visitante outros referenciais do local, como sua cultura e história.

A Tolstoi é atribuída uma frase, segundo a qual, "para ser universal, basta falar de sua aldeia”. Assim, seria correto afirmar que o CCBB transforma-se em seu próprio discurso. $\mathrm{O}$ site e o Facebook traduzem uma linguagem na outra enquanto o discurso ganha materialidade, formas.

Observa-se a presença da cordialidade na relação CCBB e público visitante, ainda que cada um (enquanto indivíduo e ser social) carregue consigo seu próprio complexo sistema de valores.

[...] o trabalho em serviços, mesmo que rotineiro, também requer autoaperfeiçoamento e aprendizado contínuos. Sabe-se que o nível de qualificação profissional dos prestadores de serviços de hospitalidade é considerado insuficiente em vários aspectos. O nível educacional, a falta de domínio de outros idiomas, o desconhecimento do cliente, a despreocupação com as necessidades dos visitantes são alguns dos fatores que impedem a evolução da qualidade dos serviços de hospitalidade. (NEVES e ALEXANDRE, 2006, p.2)

No que tange a segmentação, a visitação ao CCBB integra o turismo urbano, categoria na qual a própria cidade é destino e principal motivação para o deslocamento de seus moradores (GASTAL e MOESCH, 2007). O Centro ainda extrapola sua função de atração turística ou polo atrativo, pois não é simplesmente um lugar pelo qual o cidadão passa e vê. Caracteriza-se como destino turístico, para o qual pessoas se deslocam, saem de suas casas para ir até ele acompanhar seu calendário próprio de eventos. Nesse ínterim, o "olhar do turista" é orientado para aspectos que o separam da experiência cotidiana, que o direcionam para fora do que lhe é rotineiro, habitual (URRY, 1996). Trata-se de lugar ou espaço dotado de infraestrutura básica, com atrativos qualificados, sedimentados no pilar da interação informação-cultura-turismo-consumo-turista.

Turismo, redes e mídias sociais são fenômenos da sociedade contemporânea que vêm conquistando tanto empresas, pelas possibilidades de estratégias corporativas, quanto usuários, por possibilitar a constituição de novos laços de identidade coletiva, desafiando instituições que lidam com riscos de imagem e com grande diversidade de públicos. Castells alerta

[...] Usuários e criadores podem tornar-se a mesma coisa. Dessa forma, os usuários podem assumir o controle da tecnologia no caso da Internet [...] Há, por conseguinte, uma relação muito próxima entre os processos sociais de 
criação e manipulação de símbolos (a cultura da sociedade) e a capacidade de produzir e distribuir bens e serviços (as forças produtivas). Pela primeira vez na história, a mente humana é uma força direta de produção, não apenas um elemento decisivo no sistema produtivo. (CASTELLS, 2013, p.69)

A inovação tecnológica vem se aperfeiçoando pela prática, com usuários aprendendo, "usando" e "fazendo", promovendo uma reconfiguração de redes de novas descobertas muito mais rápidas que o desenvolvimento tecnológico do passado. Assim, não é possível subestimar o poder da linguagem. O filólogo Bakhtin, como visionário, identificara a importância da interação verbal e do interlocutor nas relações de comunicação. $\mathrm{Na} A D$ da comunicação do CCBB, a exemplo de Bakhtin, o interlocutus não é um elemento passivo na constituição do significado.

Na clássica definição de Marshal McLuhan, "o meio é a mensagem”. A comunicação faz parte do processo turístico, mas não se dá somente pelo processo objetivo, da mídia, em si, mas acima de tudo pela relação do "estar junto", de participação no sentido místico de comunicabilidade nesse ou naquele evento - como professa Maffesoli. Cada ser se integra em um conjunto que permite ao mesmo tempo ter e entrar em correspondência com o outro. A ideia toda da comunicação é "estar com". A escolha do destino turístico, por parte do consumidor, dá-se por meio da seleção dentre as diversas opções apresentadas pelas formas de comunicação interpessoal (contatos com amigos, familiares) e externa (veículos de comunicação, folheteria etc.).

Na investigação da linguagem adotada pelo CCBB Brasília, a partir da observação das publicações do nosso objeto de estudo editadas nas plataformas online (Facebook e site), não se deve ignorar tampouco as ponderações de Orlandi, para quem o discurso é língua em movimento; enquanto interdiscurso é o movimento do discurso. O pesquisador utiliza palavras dos outros para produzir suas concepções, de onde organiza seu mosaico para produzir um discurso próprio, que acredita ser seu, dentro de suas condições de produção.

Tal produção deve ser conquistada com método e regras:

Quatro noções devem servir, portanto, de princípio regulador para a análise: a noção de acontecimento, a de série, a de regularidade, a de condição de possibilidade. Vemos que se opõem termo a termo: o acontecimento à criação, a série à unidade, a regularidade à originalidade e a condição de possibilidade à significação. Estas quatro últimas noções (significação, originalidade, unidade, criação) de modo geral dominaram a história tradicional das ideias onde, de comum acordo, se procurava o ponto da criação, a unidade de uma obra, de uma época ou de um tema, a marca da originalidade individual e o tesouro indefinido das significações ocultas (FOUCAULT, 2013, p. 51). 
Não se volta atrás no tempo em que o pensador Porfírio teria a chave da resolução da ambiguidade ao afirmar: "Porque como as coisas são, assim são as expressões que primeiro as exprimem." O mundo clássico, medieval, renascentista e de pensamentos múltiplos segue em transformação. O momento é o da comunicação mediada por computadores. Nas palavras de Castells (2013, p.57), “as novas tecnologias da informação estão integrando o mundo em redes globais de instrumentalidade".

O "penso, logo existo", de Descartes, proclama: sou sujeito consciente. Parafraseando Lacan: "Onde não penso é que existo" - reapresentando-nos o sujeito do inconsciente de Freud. A Análise do Discurso vai depender sempre de como o pesquisador olha o discurso e a partir de que referencial bibliográfico. A diferença de um conhecimento científico para o prático: o papel do intérprete.

\title{
5.3.6 Respeitável público
}

Em seu chamado, o CCBB não separa cliente de não-cliente, ele procura pelo hóspede, pelo visitante. No espaço, são esperados os consumidores de entretenimento que, sob a perspectiva da cultura, são denominados público e espectador. A seguir, uma comunicação registrada no site do espaço brasiliense sobre a mostra de artes plásticas Ciclo - criar com o que temos.

Texto 20 - Ciclo - criar com o que temos

\section{sobre a mostra}

\begin{abstract}
Comemorando 100 anos dos primeiros ready-made de Marcel Duchamp, artista que inovou ao promover o deslocamento de objetos comuns para o cenário de exposiçóes de arte, a mostra reúne 15 artistas de diversas nacionalidades (Daniel Canogar, Daniel Senise, Douglas Coupland, Joana Vasconcelos, Julia Castagno, Lorenzo Durantini, Michael Sailstorfer, Michelangelo Pistoletto, Pedro reyes, Daniel Rozin, Petah Coyne, Ryan Gander, Song Dong, Tara Donovan, Tayeba Begum Lupi.

Através de esculturas, instalaçōes e performances, a exposiçāo propōe novos significados a partir de objetos do cotidiano.

Curadoria: Marcello Dantas
\end{abstract}

Fonte: http://culturabancodobrasil.com.br/portal/distrito-federal/ (Acessado em 08mar2015, às 22h24)

Como visto neste capítulo, Halliday concebe a linguagem, a partir de funcionalidades, com o objetivo de mostrar sua multiplicidade: o funcionamento próprio da língua, para quê ela serve, e suas necessidades gramaticais. Para o professor, a linguagem possui três funções, dentre as quais, a textual, cuja sentença é a mensagem, preocupando-se em afirmar que cada 
uma constitui-se em unidade de informação, porção do discurso em sentido completo. $\mathrm{O}$ CCBB, ao comunicar a realização da exposição Ciclo, parece voltar-se a um público bastante específico, posto que o texto, em sua exterioridade, usa expressão - "ready-made" - em idioma estrangeiro sem marcação e sem explicar seu significado, além de apresentar um apanhado de nomes de artistas - "Daniel Canogar, Daniel Senise, Douglas Coupland, Joana Vasconcelos, Julia Castagno, Lorenzo Durantini, Michael Sailstorfer, Michelangelo Pistoletto, Pedro reyes (aqui faltou a maiúscula), Daniel Rozin, Petah Coyne, Ryan Gander, Song Dong, Tara Donovan, Tayeba Begum Lupi" - que pouco ou quase nada comunicam ao leitor/público comum.

Em uma frase de seis linhas, o comunicado não tem tom convidativo. Ao contrário, insurge petulante, como se todos tivessem a obrigação de saber do quê e sobre o quê trata. Começa, anunciando a celebração do centenário dos iniciais "ready-made de Marcel Duchamp". Na sequência, dá indicativo de quem foi o pintor e escultor francês, ícone da vanguarda europeia da primeira metade do século XX, e enumera 15 artistas das mais diversas nacionalidades - sem citar quais países representam. Enquanto isso, o leitor provavelmente segue aguardando o significado dos "ready-made".

Neste parágrafo, observa-se a linguagem como lugar da constituição da subjetividade. O sujeito, quem fala, o original produtor da mensagem. A imagem que dele emerge é a de caráter elitista e pouco afeito a disseminar a informação. O fato surpreende, tendo em vista a vocação popular e voltada para a acessibilidade do Centro, além do próprio conceito da exposição em questão. O enunciado não condiz com a mostra, a qual, por meio de "esculturas, instalações e performances [...] propõe novos significados a partir de objetos do cotidiano", explica no segundo parágrafo. De cunho educativo, os trabalhos mostravam a força criativa e transformadora da arte, ao oferecer outras possibilidades de uso para conhecidos objetos, tais como copo de plástico, palitos de fósforo, armas letais, câmaras de pneus, absorventes íntimos, dentre outros objetos. Tal associação passa ao largo das informações inseridas no site. No entanto, nas postagens do Facebook, as palavras descrevem o material de que são feitos os sonhos - os quais puderam ser apreciados por quem esteve no CCBB entre fevereiro e abril de 2015, período em que permaneceu em cartaz - como nos exemplos a seguir: 
Texto 21 - Fantasma de Eguchi, de Petah Coyne

A obra 'Fantasma de Eguch" fol inspirada em uma história japonesa e foi feita a partir da carroceria de um traller americano. Quer saber mais? 3. . Marque uma visita guiada $\in$ mergulhe fundo na exposiçào Cicloł Agende pelo telefones: 2 (61) $3108-7623$ ou 2 (61) $3108-7624$ (2)

Facebook 15 - Acessado em 21abr2015, às 23h07

Texto 22 - Desarme, de Pedro Reyes

A instalação do artista mexicano Pedro Reyes utilizou mais de seis mil armas apreendidas pelo governo para criar instrumentos musicais automatizados que formam uma banda, totalmente programada e operada por computador. $\mathrm{O}$ artista utilizou algo que já tirou muitas vidas e transformou isso tudo em algo positivo. Eu \#reCiclo e você? ¿(-)

Facebook 16 - Acessado em 16abr2015, às 14h54

Texto 23 - Vamos dar um tempo, de Tayeba Lipi

Sim, é uma banheira totalmente revestida por lâminas de barbear! Na obra "Vamos dar um tempo", a artista Tayeba Lipi utiliza materiais cortantes, como as lâminas e os alfinetes de segurança, para remeter à violência sofrida pelas mulheres e às questões baseadas em estereótipos de sensualidade e dominação. Interessante, não é? Pensou cultura, pensou \#CCBBBrasília! \#reCiclo (-):

Facebook 17 - Acessado em 21abr2015, às 23h07

Texto 24 - A noiva, de Joana Vasconcelos

A artista Joana Vasconcelos usou mais de 25 mil O.B.'s para fazer este lustre. A obra já passou pela Bienal de Veneza e seria exposta no Palais de Verssailes, mas foi vetada. Uma pena! Quer saber mais? Que tal agendar uma visita mediada? Agende pelo telefone: (61) 3108-7623 ou (61) 3108-7624 (2)

Facebook 18 - Acessado em 08mar2015, às 19h07

Texto 25 - Modelo para a sobrevivência, de Julia Castagno

A uruguaia Julia Castagno utilizou um objeto que é muitas vezes desvalorizado e criou algo belo. Foram cerca de 100 mil palitinhos de dente. Ela acredita que, assim como os seres humanos, cada palito é único, pois tem a sua própria história e o fato de estarem unidos é fundamental para que a obra se sustente. Venha ver de pertol \#PorTrásDaObra \#reCicio \#CCBBBrasilia

Facebook 19 - Acessado em 10mar2015, às 21h40 
Texto 26 - Slogans para o século 21, de Douglas Coupland

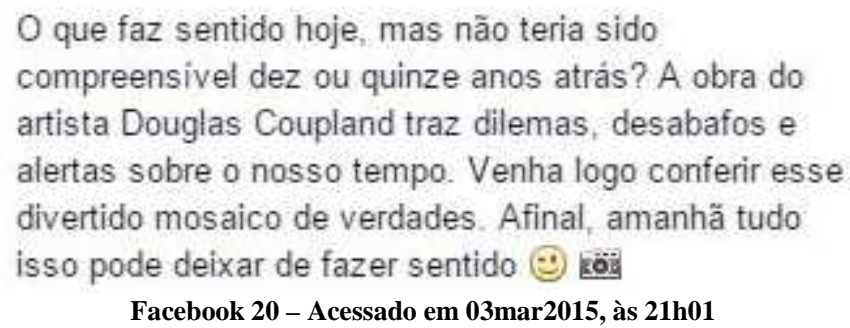

Facebook 20 - Acessado em 03mar2015, às 21h01

Observa-se que, nas inserções acima, o convite é feito por meio de textos criativos, que, de certa forma, dialogam com a própria obra. Ao mesmo tempo em que fornecem pistas sobre o que o visitante verá, preocupa-se em narrar histórias e contextos de criação. Como visto no quarto capítulo, a abordagem da comunicação indica que o indivíduo tem uma necessidade de informar-se a partir do ambiente social, sendo a palavra o meio pelo qual o ser humano conhece (a si mesmo, as coisas e o outro) e se relaciona (consigo mesmo, com as coisas e com o outro).

As duas páginas - a do site e a do Facebook - parecem feitas por dois sujeitos falantes distintos. Na inserção do site, por meio da linguagem objetiva e sucinta, o anfitrião não se mostra tão receptivo ao visitante, beirando a petulância, como se fosse obrigação de todos conhecer os artistas envolvidos, bem como saber de antemão a pretensão dos trabalhos reunidos. Seria, como destaca Schiffrin (1994), o discurso do formalista, cuja preocupação é para com o ordenamento e a articulação dos elementos textuais, sem considerar os contextos comunicativos da fala. Nas postagens do Facebook, porém, o hospedador assume discurso conciliador, didático, e, de certa forma, original, de abordagem funcionalista, presumindo inter-relação entre linguagem e contexto. É o mecenas posicionando-se por meio da apropriação da linguagem da informalidade, criando uma identidade de hospitalidade. 


\section{CONCLUSÃO}

No campo minado da informação, o Turismo é um fenômeno inventado, que nasceu e vem se desenvolvendo no âmago da sociedade complexa. Suas múltiplas facetas dão ao lugar um espaço privilegiado no contexto de seus estudos, porque é nesse território que se promovem as condições para o turismo urbano.

Tem-se na Inglaterra, berço da revolução industrial, a primeira organização da prática turística, quando pessoas se deslocam de um lado para o outro do arquipélago com o intuito de deleite. Essas ações se deram, devido a condições objetivas de uma realidade: classe trabalhadora organizada, assalariada e com tempo livre. Camargo (2011, p.19 e 97) lembra que as exposições internacionais pensadas para atrair turistas surgiram na Londres de 1844, inaugurando a era de eventos organizados "sem a inspiração e/ou o controle do poder sociorreligioso, com a participação crescente da iniciativa empresarial, tornando-se mais uma peça na engrenagem da economia capitalista". O turismo, assim, desde sempre, surge como um grande sistema composto de uma realidade social, cultural e política estabelecida em um território que, por sua vez, possui uma maneira própria de dispor de sua lógica e de suas possibilidades.

Tudo - praia, campo, cidade - está sob a ótica do capital. Não escapa dessa premissa nem mesmo a hospitalidade, a qual, outrora, na Grécia antiga, era oferecida gratuitamente e considerada uma das mais belas virtudes da humanidade, posto que, ter um hóspede em casa significava ser abençoado pelos deuses.

É um consumo diferente dos demais (BOYER, 2003) esse fenômeno chamado turismo. O ser humano prescinde dele para existir; não se trata de uma necessidade básica, segundo a Pirâmide de Maslow, mas de sociabilidade e status. Viajar, conhecer lugares confere ao sujeito uma posição privilegiada na sociedade.

Fruto da criatividade e da predisposição do homem de conhecer e reconhecer-se nas marcas da antiguidade projetadas na arquitetura, na história, nas culturas, o turismo tornou-se parte do conhecimento a ser adquirido e desfrutado. E o primeiro passo é o desejo. É preciso querer ir ao seu encontro, se deslocar, para [melhor] percebê-lo. Trata-se de uma fonte de sabedoria não-estanque, que circula e clama pela experiência.

Entende-se, assim, não haver por que resistir ao investimento do capital no turismo. Afinal, é inegável sua participação no desenvolvimento de sua prática cotidiana - do transporte de pessoas à circulação de informações. 
Turismo, no entanto, tem raízes polissêmicas. Para além de sua conexão com o capitalismo, movimenta-se nas mais complexas redes estabelecidas pela sociedade. Sob essa perspectiva, envolve relações sociais, promove encontros, inclusive disciplinares, e se fortalece em categorias que preservam sua importância para quem o pratica. A Hospitalidade, sendo uma delas, com suas condições de acolhimento, visitação, em ambiente ocupado por anfitrião e hóspede, esferas cujas conceituações imiscuem-se, emerge com poder de atribuir e promover outros significados aos espaços constituídos.

$\mathrm{Na}$ estratégia corporativa do Banco do Brasil, a aproximação de funcionários, acionistas, clientes e não-clientes passa, necessariamente, por ações socialmente responsáveis. E uma delas gira em torno da criação e manutenção dos quatro centros culturais sediados em Belo Horizonte, Brasília, Rio de Janeiro e São Paulo. Não se pode negar que cada um, à sua maneira, e todos, em seu conjunto, representam um "poderoso diferencial competitivo", a distinguir a instituição da concorrência (ZAGHEN, 2000).

O Centro Cultural Banco do Brasil carioca veio primeiro, em 1989, tornando-se referência no cenário nacional pela qualidade, diversidade e regularidade da programação. $\mathrm{Na}$ sequência, foram constituídos o brasiliense, o paulista e o mineiro. A escolha dos edifícios históricos que abrigam os quatro centros, com a preocupação de revitalização da região e acessibilidade, demonstra ser um instrumento efetivo de contato com a coletividade, primando por qualidade de vida e bem estar do público. Nesses espaços que abrigam a cultura em suas variadas manifestações, de modo especial, a artística, a identidade sisuda, mercantil, corporativa, da entidade financeira dá lugar à do incentivador dos usufrutos da liberdade e do prazeroso tempo livre por parte do cidadão, do estrangeiro, do visitante.

Cabe destacar que três dos centros estão situados na região central das capitais e com acesso facilitado a quem se aproxima. O CCBB Brasília, nesse ponto, possui peculiaridades. Sua origem remonta a um projeto muito maior, que visava à integração da cidade. É um lugar pelo qual não se passa, simplesmente. Ele não está no caminho da casa ou do trabalho das pessoas; ao contrário, é um local para onde é preciso se deslocar com o intuito de lá estar. A distância dos elementos urbanos centrais - centro da cidade, rodoviária etc. - e as condições de locomoção foram sempre levados em consideração pelos seus gestores, tanto que, desde sua criação, em 12 de outubro de 2000, um ônibus é oferecido pelo Centro para todo e qualquer visitante, sem contar os veículos disponibilizados para as escolas públicas levarem seus alunos para visitas guiadas dentro do Programa Educativo, um dos projetos de maior visibilidade do espaço e que tende à formação de plateia, de apreciadores de arte. Receptiva a quem dele deseja se aproximar, a gestão considera as características da cidade e de seus 
frequentadores, mantendo-se no intuito de cumprir seu papel de inserir a capital do País no roteiro nacional dos eventos e das produções culturais. Como assinala Milton Santos (2006, p.213), ao mesmo tempo em que cada lugar é o mundo, “à sua maneira”, ele é "exponencialmente diferente dos demais", pois não perde sua "individualidade".

A solução para o deslocamento é um desdobramento dessa condição da cidade de Brasília, turística por natureza, pelos inusitados traçados de Lúcio Costa e pela arquitetura de referência mundial de Oscar Niemeyer - este, autor do prédio que abriga o Centro. Assim também o desenvolvimento dos canais de comunicação para divulgar a programação, pensada especialmente para o público do CCBB Brasília. Para fins deste estudo, selecionaram-se páginas do CCBB DF, no site (www.bb.com.br/cultura) e no Facebook (www.facebook.com/ccbb.brasilia), por serem ambas disponíveis na Internet, à qual 71,4\% dos domicílios brasilienses têm acesso (IBGE, 2014) ${ }^{34}$. A comunicação, entende-se, é um vetor da experiência turística, pois atravessa barreiras, muros e torna impraticável o aparte da sociedade, especialmente com o desenvolvimento tecnológico representado pela rede de computadores.

A empresa precisa e se adapta ao meio. $\mathrm{Na}$ "sociedade em rede", como apregoa Castells (2013), a comunicação desempenha papel primordial na socialização, mas também no âmbito da "dominação social". E o discurso é o vetor pelo qual o sujeito é interpelado.

A cena hospitaleira, no cenário deste estudo, é composta por um ritual que começa com um convite. Efetuado pelo meio virtual, site e Facebook, esse é construído de modo a estabelecer, por meio do discurso, a identidade do espaço como lugar de acolhimento e visitação. E, ainda que seja público, inclui - os que apreciam a programação proposta pelo Centro Cultural Banco do Brasil Brasília - e exclui - os não-aderentes ou desinteressados pelo tema. "Os incluídos são os iguais de alguma forma" (CAMARGO, 2011, p.15).

Sob o ângulo do anfitrião, especialmente no de viés mercadológico, valorizar o visitante é parte de sua estratégia. A segmentação de públicos, por meio de programação diversificada e brindes, tende a reforçar o vínculo social e a fidelização do cliente do principal mecenas do espaço.

A programação, o que se verá, já fora definida previamente, por meio de processos seletivos que consideram aspectos apontados no eixo curatorial dos editais adotados. E o CCBB DF apresenta ao público, não apenas arte e artistas de renome nacional e internacional,

\footnotetext{
${ }^{34}$ Pesquisa Nacional por Amostra de Domicílios (Pnad) divulgada pelo Instituto Brasileiro de Geografia e Estatística (IBGE) mostrou que, em 2013, 49,5\% dos domicílios brasileiros tinham computadores, sendo 43,7\% deles com computador ligado à internet. Por outro lado, observou-se queda no número de residências com rádio - de 80,9\% para 75,8\% - e DVD - de 76\% para 72,4\% - de 2012 para 2013 (IBGE, 2014).
} 
mas também destaques regionais nos mais diversos segmentos em que atua - artes plásticas, artes cênicas, música, cinema, ideias. Assim, ao valorizar o local, contribui para a aproximação e identificação com os residentes. Um anfitrião precisa pensar em ser acolhedor não só com o estrangeiro, com aquele que vem de fora, mas também para com aqueles que lhe são mais próximos.

A complexidade do turismo se estabelece a partir do afastamento simbólico do cotidiano. Assim, ainda que permaneça dentro da cidade onde vive, o visitante busca a novidade, o conhecimento novo. Como lembra Camargo $(2011,22)$, a cena hospitaleira, outrora referência familiar, atualmente é valorizada "pela linguagem empresarial como responsabilidade social [...] pela promoção de visitas programadas às suas instalações pelos habitantes desse entorno [...]".

O número de visitantes conquistados, que a cada dia se interessam mais e mais pelo CCBB DF, parece comprovar que o Centro quebrou paradigmas, já que houve tempo que era identificado pelo visitante como um espaço destinado ao turista elitista, em função da dificuldade de se chegar ao local e pela programação oferecida, considerada de baixo apelo popular e voltada para públicos com acesso a pesquisas e a formas diferenciadas de arte. Observa-se, no entanto, a existência de lampejos de certa petulância, como se todos tivessem a obrigação de saber do quê e sobre o quê trata o programa apresentado. É o caso, como observado, do chamado para a exposição "Ciclo", na qual são utilizados termos em inglês, sem tradução, e uma listagem de nomes, sem referência às suas origens, obras e representatividade.

Mas a hospitalidade é incondicional, lembra Derrida. A cada um, anfitrião e hóspede, cabe executar uma tarefa. Um e outro devem honrar-se mutuamente, ainda que riscos se façam presença - para quem chega, o da rejeição ou da opressão, para aquele que recebe, o da inconveniência. $\mathrm{O}$ frequentador do $\mathrm{CCBB}$ conhece as regras do espaço e as segue ou transgride, sabendo das condições de receptividade do anfitrião. Os cidadãos de Brasília reconhecem o Centro como seu e nele procuram estar como visitantes, apropriando-se das áreas externas e participando ativamente das ações de lazer e entretenimento oferecidas. São construções de identidade evidenciadas e cujas relações assimétricas de poder são mantidas e reconstruídas nas práticas sociais.

O Banco do Brasil, por meio do discurso, apresenta-se como fomentador de cultura, um mecenas, apropriando-se de um linguajar de informalidade para penetrar no espaço, materializando seu símbolo dentro de outros universos, o cultural e o turístico. O cultural, porque se empenha em oferecer à cidade uma programação exclusiva, intensa, diversificada, 
abrangente do universo artístico do Brasil e do mundo. E o turístico, porque faz de si mesmo um destino, um lugar para onde as pessoas, residentes ou não na capital federal, se deslocam e se encontram, atraídas pela programação, pela acolhida com a qual se depara, desde que recebe o convite pelo meio virtual até o desfrute do ambiente. Como destaca Yázigi (2001, p.33), "a região turística corresponde a uma área com certa densidade de frequentação, serviços e equipamentos turísticos e com uma imagem que lhe caracteriza".

O anfitrião controla as regras, domina a cena, enquanto o convidado a essas se submete. Em alguns casos, sente-se tão bem-recebido que pressupõe a necessidade de retribuir e torna-se, ele mesmo, no espaço do outro, um hospedador. Essa relação é observada nos constantes convites que o próprio Centro faz aos seus frequentadores, para que convidem amigos, parentes e conhecidos a visitar o espaço. O cidadão, acarinhado, parece orgulhar-se de ter, em sua cidade, um lugar como o CCBB para chamar de seu.

No CCBB DF, desde o convite realizado por meio do site e das redes sociais, o Centro atua como aglutinador, estimulando a população a incorporar, em seu cotidiano, o hábito de visitá-lo com o olhar não de um turista qualquer, sem vínculo com o lugar, mas de alguém próximo, cuja percepção ultrapassa os sentidos daquele que recebe. E o cidadão de Brasília apropria-se do espaço, tornando-se turista na cidade em que reside, ao mesmo tempo, hóspede e anfitrião. Parece que o indivíduo quer vivenciar "experiências de estranhamento em relação ao desconhecido, incluindo o lugar onde se vive" (GASTAL e MOESCH, 2007, p.29).

E o CCBB parece fazer do turista o protagonista do espaço por diversos modos. Em primeiro lugar, escolhe programação voltada para esse visitante; em segundo, faz um convite especialmente dedicado a este, já que o site e a página do Facebook destinam-se aos espectadores; e em terceiro, porque dá a ele, desde cedo, o poder do convite, de tornar-se, ele próprio, anfitrião, ao incentivá-lo a convidar amigos e familiares para apreciar o ambiente preparado para recebê-lo.

Não se deve esquecer que o CCBB é, ele próprio, um hóspede que se tornou anfitrião, apropriando-se do lugar de maneira cativante para todos os que o frequentam. Na ação e na linguagem, é o lugar de residência do exercício do poder institucional que utiliza o espaço para homogeneizar (SERPA, 2004). E, assim, o CCBB DF pauta a cultura na capital federal e, em seu discurso, deixa claro que oferece uma programação representativa do universo artístico e, no mínimo, edificante para o público visitante. E, claro, que esse é sempre bemvindo.

"Mas há inúmeros riscos embutidos nessa cena", alerta Camargo (2011, p.17). Para quem recebe, a "intrusão", "o parasitismo" ou a "inconveniência”; para quem chega, a 
inospitalidade, que pode ser um tratamento ríspido, um ambiente poluído ou excesso de gentilezas. Quando convida, o CCBB não separa cliente de não-cliente, ele procura pelo visitante. Afinal, no espaço, são esperados os consumidores de entretenimento sob a perspectiva da cultura.

O especulado caráter acolhedor da arte, de quem a faz e produz, repercute na perspectiva da hospitalidade. E para uma empresa manter-se no mercado, como recomenda o "Guia para formação e utilização de espaços culturais", não basta prestar serviços de qualidade; ela precisa "mostrar-se indispensável, integrada ao meio, corresponsável pelo ambiente onde atua" e realizar "eventos que valorizem as manifestações artísticas e culturais nas diversas regiões do País" (CENTRO CULTURAL BANCO DO BRASIL, 1997, p.3). É a capacidade transformadora de uma das mais longevas instituições do mundo, com mais de 200 anos de atuação.

Ressalta-se que tudo começa e se constrói por meio de um discurso a determinar a comunicação de um destino que deixa de se identificar com o sistema financeiro ao se inserir na práxis transformadora e modernizante da cidade. O investimento do Banco em cultura é um instrumento efetivo de contato com a coletividade e reforça a marca da empresa que, ali, torna o turista o personagem principal de sua própria experiência - a este é dada a possibilidade de participar, tirar e postar fotografias nas redes sociais, o que lhe confere status e poder de influenciar outras pessoas, gerando um círculo de relações entre o CCBB e seus visitantes.

Os dados gerados pela pesquisa identificam espaços discursivos de poder, posto que o lugar de fala é o da perpetuação das assimetrias, cabendo ao usuário, enquanto turista e visitante, a criticidade na aceitação do convite veiculado. As informações coletadas apontam para evidências da utilização do discurso enquanto ferramenta de manutenção do poder hegemônico por parte do mecenas, por meio da atuação no campo das artes. A partir do referencial adotado e da apresentação das evidências, das quais foram preservadas somente o corpus do dominante, depreende-se que o que não está sendo dito também comunica.

$\mathrm{Na}$ investigação da linguagem adotada pelo CCBB Brasília, a partir da observação das publicações do nosso objeto de estudo editadas nas plataformas online (Facebook e site), o discurso é língua em movimento, enquanto interdiscurso é o movimento do discurso (ORLANDI, 2013). Não se procura mais, como nas marcas históricas destacadas por Foucault (2013, p.51) "o ponto da criação, a unidade de uma obra, de uma época ou de um tema, a marca da originalidade individual e o tesouro indefinido das significações ocultas". No discurso do Centro, verifica-se, não é preciso criar projetos, mas acolhê-los e transformá-los 
em acontecimentos para usufruto do turista; a sequência de uma programação diversificada, que atinge a todos, é valorizada no lugar de uma mostra que pode soar como repetitiva e sem apelo; a regularidade de apresentação de projetos que possam tocar públicos diferenciados é vista como original nos tempos atuais, nos quais o significado de toda a produção passou a ser individualizado.

O diálogo estabelecido com a teoria do Turismo e com as interdisciplinaridades a ele conexas, como Linguística, Comunicação e Geografia, possibilita a percepção de como as perspectivas sobre as relações de poder colaboram para a constatação da existência sobre de que maneira "discurso" e "linguagem" se concentram no coração das práticas e dos processos sociais modernos. O CCBB DF, por meio de um discurso hospitaleiro, apresenta-se como fomentador de cultura, um mecenas, apropriando-se de um linguajar informal para penetrar no espaço, materializando seu símbolo dentro de outros universos, dentre eles o turístico.

Reside, aqui, uma necessidade de compreensão da concepção e da composição do lugar, a partir de uma identidade edificada por meio de questões formuladas: o CCBB DF foi criado, sob a perspectiva da hospitalidade, por quem, a partir do quê, para quem e para o quê. Pelos estudos efetuados, respostas preliminares indicam que o Centro foi concebido pelo desejo da "maior instituição financeira da América Latina em termos de ativos" (BANCO DO BRASIL, 2015a) "inserir a capital do País no roteiro internacional dos grandes eventos e produções culturais" (BANCO DO BRASIL, 2013), para “o público maravilhoso que nos vem acompanhando" (Texto 5 - Aniversário $C C B B$ ). Tudo isso para além do significado simbólico de trazer para o domínio de seu fomentador - o Centro enquanto lugar físico -, no qual há possibilidade, ainda que sem a rigidez da porta giratória automática de uma de suas agências, de controle sobre a frequência, sobre quem são os turistas que o visitam, sobre o tempo de permanência no espaço e sobre o catálogo de eventos oferecidos.

Ainda que o Centro tenha sido configurado e se fortaleça como lugar de cultura, se identifique e faça de si mesmo um destino turístico, hospitaleiro, e espaço de encontro para o visitante, ideologicamente, ele está integrado aos propósitos de quem o criou. O CCBB DF é um lugar que está no inconsciente coletivo, incorporado à ideia de lazer do cidadão brasiliense, e tem como referente a arte em seu aspecto relacional com a cultura. Como espaço pluridisciplinar, não exclui sua identificação com o condicionamento e o adestramento do visitante. Afinal, ao mesmo tempo em que o anfitrião concede ao hóspede liberdade, esta é vigiada por um poder disciplinar e regulador.

À luz de Orlandi (2013, p.69), as observações analisadas partem do discurso, ao qual não interessa "a organização linguística do texto, mas como o texto organiza a relação da 
língua com a história no trabalho significante do sujeito em sua relação com o mundo". Observa-se, pela recursividade do texto dentro das redes sociais, a inexistência de conflito entre a função primeira do Banco do Brasil, a de ser uma instituição mercantil de crédito, que recebe depósitos em dinheiro, opera em câmbio e aplica capitais, dentre outros, e sua atuação como mecenas, incentivador das artes e da cultura. Ao contrário, por meio de seus quatro centros culturais, o banco torna tangível um dos aspectos de correspondência e valorização da marca. O mesmo não se pode afirmar quanto ao confronto ideológico, tendo em vista que, como falante, o BB tem, na internet e em seu espaço de lazer, um canal de ampla disseminação das suas práticas sociais, revelando e refletindo seus próprios valores, ainda que metaforicamente. Importante considerar a inferência de que grande parte dos frequentadores de seus espaços culturais, seu público visitante, conhece e se reconhece na comunicação do Banco do Brasil para a cultura. A situação do visitante em sua relação com o CCBB, também na linguagem, está intrinsecamente ligada ao acolhimento, ao contato com o outro. 


\section{REFERÊNCIAS}

AGÊNCIA DO ARADE. O destino turístico Arade: Uma estratégia de intervenção. Portimão: Agência do Arade-Associação de Desenvolvimento do Arade, 2005.

ALTHUSSER, L. Aparelhos ideológicos de Estado: nota sobre os aparelhos ideológicos de Estado. $6^{a}$ ed. Rio de Janeiro: Graal, 1992.

ALVES, M. R. Banco do Brasil consegue lucrar 18 vezes o que investe em patrocínios culturais. Estadão, São Paulo, 13out.2015. Disponível em:

$<$ http://economia.estadao.com.br/noticias/negocios,banco-do-brasil-consegue-lucrar-18vezes-o-que-investe-em-patrocinios-culturais,1778822>. Acesso em: 13out.2015.

ARENDT, H. A condição humana. 10ª ed. Rio de Janeiro: Forense Universitária, 2007.

AURAIX-JONCHIÈRE, P. Castelo: entre acolhida e hostilidade. In: MONTANDON, A. (org.). O livro da hospitalidade: acolhida do estrangeiro na história e nas culturas. São Paulo: Senac, 2011. p. 471-480.

BACZKO, B. A imaginação social. In: LEACH, E. E. A. Anthropos-Homem. Lisboa: Imprensa Nacional/Casa da Moeda, 1985.

BAKHTIN, M. (Voloshínov, 1929). Marxismo e filosofia da linguagem. 15ª ed. São Paulo: Editora Hucitec, 2009.

BANCO DO BRASIL. História do Banco do Brasil. Rio de Janeiro: Ítalo Bianchi Publicitários Associados Ltda., 1988.

O processo de construção da estratégia no Banco do Brasil, 2009.

Disponível em: 〈http://www.bb.com.br/docs/pub/siteEsp/ri/pt/dce/dwn/bbdayEO.pdf〉. Acesso em: 12jan.2016.

Regulamento da Promoção "Curta 2012 no CCBB”. Centro

Cultural Banco do Brasil, 2011. Disponível em:

<http://www.bb.com.br/portalbb/page512,128,10189,1,0,1,1.bb?codigoMenu=9926\&codigoN oticia=32678> . Acesso em: 29set.2015.

Edital de Seleção de Projetos Culturais 2013/2014. Centro Cultural

Banco do Brasil, 2012. Disponível em:

<http://www.bb.com.br/docs/pub/inst/dwn/EditalCCBB1314.pdf>. Acesso em: 04 out. 2015.

BANCO DO BRASIL. Facebook CCBB DF, 2012. Disponível em:

$<$ https://www.facebook.com/media/set/?set=a.379681675377508.95341.225664190779258\&t ype=3>. Acesso em: 29set.2015.

A história. CCBB DF: conheça a nossa história. Cultura Banco do

Brasil, 10nov.2013. Disponível em: <http://culturabancodobrasil.com.br/portal/distritofederal>. Acesso em: 13out.2014.

BB anuncia expansão do CCBB Brasília, com novo museu. Portal

Banco do Brasil, 2013. Disponível em:

<http://www.bb.com.br/portalbb/page118,3366,3367,1,0,1,0.bb?codigoNoticia=39046>.

Acesso em: $1^{\circ}$ out. 2015.

. CCBB Espaços. Centro Cultural Banco do Brasil, 2013a.

Disponível em: <http://culturabancodobrasil.com.br/portal/>. Acesso em: 15maio/2014. 
Brasil, 2013b. Disponível em:

Banco do Brasil inaugura o CCBB Belo Horizonte. Portal Banco do <http://www.bb.com.br/portalbb/page118,3366,3367,1,0,1,0.bb?codigoNoticia=38673>. Acesso em: 26abril/2015.

Edital de Cessão de Espaço 2014/2015 - CCBB. Centro Cultural

Banco do Brasil, 2013c. Disponível em:

<http://www.bb.com.br/docs/pub/inst/dwn/editalccbb1415.pdf>. Acesso em: 04out.2015.

Renascimento no CCBB, 2013d. Disponível em:

<http://www.renascimentonoccbb.com.br/>. Acesso em: 03maio/2015.

CCBB RJ. Facebook, 2014. Disponível em:

<https://www.facebook.com/ccbb.rj/photos/a.160941120639232.39834.160517634014914/71 4952905238048/>. Acesso em: 25set.2014.

Edital de seleção pública de projetos culturais 2015/2016. Centro

Cultural Banco do Brasil, 2014a. Disponível em:

$<$ http://culturabancodobrasil.com.br/portal/wp-content/uploads/2014/08/EDITAL-DE-

SELE\%C3\%87\%C3\%83O-DE-PROJETOS-CULTURAIS-2015-2016-Patroc\%C3\%ADnio-eCess\%C3\%A3o-final-SAC.pdf>. Acesso em: 02maio/2015.

Publicado o Edital de Patrocínios, Cessão dos Espaços e

Regulamento do Prêmio CCBB Contemporâneo. Centro Cultural Banco do Brasil, 2014b. Disponível em: <http://culturabancodobrasil.com.br/portal/2015-2016-patrocinios-cessao-deespaco-e-premio/>. Acesso em: $1^{\circ}$ out.2015.

Portal BB: Notícias: Banco do Brasil está entre as empresas mais éticas do mundo. Banco do Brasil, 2015. Disponível em:

<http://www.bb.com.br/portalbb/page118,3366,3367,1,0,1,0.bb?codigoNoticia=44091>. Acesso em: 31out.2015.

Divulgado o resultado do Edital 2015/2016. Banco do Brasil, 2015a.

Disponível em: <http://culturabancodobrasil.com.br/portal/resultado-edital-20152016/>.

Acesso em: 02maio/2015.

Brasília, p. 186. 2015a.

Relatório de Atividades 2014. Centro Cultural Banco do Brasil.

Relatório anual 2014: Mais de 200 anos de história. Banco do

Brasil, 2015b. Disponível em:

<http://www45.bb.com.br/docs/ri/ra2014/pt/04.htm\#mais_de_200_anos_de_historia>. Acesso em: 02out.2015.

. CCBB DF. Facebook, 2015c. Disponível em:

<https://www.facebook.com/ccbb.brasilia/info?tab=page_info>. Acesso em: 26abril/2015.

Cultura. Banco do Brasil. Disponível em:

<www.bb.com.br/cultura>. Acesso em: 27abril/2105.

Espaços - CCBB DF. Centro Cultural Banco do Brasil, s/d.

Disponível em:

<http://www.bb.com.br/portalbb/page509,128,10136,0,0,1,1.bb?codigoNoticia=18050\&codig oMenu=10675>. Acesso em: 15out.2014.

Banco do Brasil. Banco do Brasil, s/da. Disponível em:

<http://www.bb.com.br/portalbb/home24,136,3525,0,0,1,8.bb?codigoNoticia=19378\&codigo Ret $=1061 \&$ bread=1\&codigoMenu=204>. Acesso em: $27 \mathrm{abril} / 2015$. 
BAPTISTA, I. Lugares de hospitalidade. In: DIAS, C. M. M. (org.). Hospitalidade: reflexões e perspectivas. $1^{\mathrm{a}}$ ed. Barueri, SP: Ed. Manole Ltda., 2002. p. 157-164.

BARROSO, E. P. Brasília: O processo de urbanização na cidade das palavras. In: Brasília: As controvérsias da utopia modernista na cidade das palavras.

Tese apresentada ao Departamento de Sociologia/Instituto de Ciências Sociais da Universidade de Brasília, 2008. p. 56-84.

BAUMAN, Z. Modernidade líquida. Rio de Janeiro: Zahar, 2003.

. Ensaios sobre o conceito de cultura. Rio de Janeiro: Jorge Zahar, 2012.

BENI, M. C. III Seminário de Análise Estrutural do Turismo. Brasília: CET/UnB. 08 a 12 setembro 2014. III SEMINÁRIO DE ANÁLISE ESTRUTURAL DO TURISMO. CET/ UnB: Brasília (DF), 08 a 12 de setembro de 2014.

BESSONE, M. Exclusão: excluído e marginalizado. In: MONTANDON, A. (org.). O livro da hospitalidade: acolhida do estrangeiro na história e nas culturas. São Paulo: Senac, 2011. p. 1089-1102.

BOTTON, A. D.; ARMSTRONG, J. Arte como terapia. $1^{\text {a }}$ ed. Rio de Janeiro: Intrínseca, 2014.

BOURDIEU, P. O poder simbólico. Lisboa: Difel, 1989.

BOYER, M. História do turismo de massa. Bauru: Edusc, 2003.

BRANDÃO, H. H. N. Introdução à análise do discurso. $3^{a}$ ed. rev. ed. Campinas, SP: Editora da Unicamp, 2012.

BURNS, P. M. Turismo e Antropologia: uma introdução. São Paulo: Chronos, 2002.

CAMARGO, L. O. D. L. El paradigma de la hospitalidad. In: NECHAR, M. C.; PANOSSO NETTO, A. (orgs.). Epistemología del Turismo: Estudios críticos. México: Trillas, 2010. p. 129-153.

CAMARGO, L. O. D. L. Apresentação à edição brasileira: O estudo da hospitalidade. In: MONTANDON, A. (org.). O livro da hospitalidade: acolhida do estrangeiro na história e nas culturas. São Paulo: Senac, 2011. p. 13-30.

CARVALHO, J. M. D. Cidadania no Brasil: O longo caminho. $15^{\text {a }}$ ed. Rio de Janeiro: Civilização Brasileira, 2012.

CASTELLS, M. Paraísos comunais: Identidade e significado na sociedade em rede. In: O poder da identidade. São Paulo: Paz e Terra, 1999. p. 21-92.

A sociedade em rede. A era da informação: economia, sociedade e cultura (vol.1). São Paulo: Paz \& Terra, 2013.

CENTRO CULTURAL BANCO DO BRASIL. Guia para formação e utilização de espaços culturais. Rio de Janeiro: CCBB, 1997.

CONSTANTINESCU, M. Intertextualidade: práticas e relações textuais. In: MONTANDON, A. (org.). O livro da hospitalidade: acolhida do estrangeiro na história e nas culturas. São Paulo: Senac, 2011. p. 669-681.

CORREIO BRAZILIENSE. Um centro cultural. Aniversário dá orgulho. . Editorial Caderno Cidade, Brasília, 10out.2003.

CRESWELL, J. W. Projeto de pesquisa: Métodos qualitativo, quantitativo e misto. $3^{\text {a }}$ ed. Porto Alegre: Artmed, 2010. 
CROSS, R.; THOMAS, R. J. Redes sociais: Como empresários e executivos de vanguarda as utilizam para obtenção de resultados. São Paulo: Editora Gente, 2009.

CULTURA E MERCADO. CCBB Brasília completa 2 anos. Cultura e Mercado, 2002. Disponível em: <http://www.culturaemercado.com.br/site/noticias/ccbb-brasilia-completa-2anos/>. Acesso em: 29out.2015.

CYPRIANO, F. Mostra com obras superficiais deveria se chamar 'Truque'. Folha de S.Paulo, São Paulo, 23set.2014. Disponível em:

<http://www1.folha.uol.com.br/ilustrada/2014/09/1520311-critica-mostra-com-obrassuperficiais-deveria-se-chamar-truque.shtml>. Acesso em: 17fev.2015.

DALlARI, D. D. A. Direitos Humanos e Cidadania. $2^{\text {a }}$ ed. reform. ed. São Paulo: Moderna, 2004.

DANTAS, G. (Ascom/Ibram). Exposições brasileiras estão entre as 20 mais visitadas no mundo em 2014. Ibram, 2015. Disponível em: <http://www.museus.gov.br/tag/ranking/>. Acesso em: 30abril2015.

DEMO, P. Vícios Metodológicos. Brasília: UnB, 2003. Disponível em: http://docslide.com.br/documents/demo-pedro-vicios-metodologicos.html. Acesso em: mar./2014.

DERRIDA, J. Anne Dufourmantelle convida Jacques Derrida a falar da hospitalidade/ Jacques Derrida [Entrevistado]; Anne Dufourmantelle. 1 1a ed. São Paulo: Escuta, 2003.

DESVALLÉES, A.; MAIRESSE, F. (ed.). Conceitos-chave de museologia. São Paulo: Comitê Brasileiro do Conselho Internacional de Museus: Pinacoteca do Estado de São Paulo: Secretaria de Estado da Cultura, 2013.

DIÁRIO OFICIAL DA UNIÃO. Banco do Brasil S/A: Relatório da Administração. Diário Oficial da União - Seção 1, 2015. Disponível em:

$<$ http://pesquisa.in.gov.br/imprensa/servlet/INPDFViewer?jornal=1\&pagina=18\&data=25/02/ 2015\&captchafield=firistAccess $>$. Acesso em: 27abr.2015.

ELIAS, N. O processo civilizador: Uma história dos costumes. Rio de Janeiro: Jorge Zahar, 1990.

Mudanças na balança nós-eu (1987). In: A sociedade dos indivíduos.

Rio de Janeiro: Jorge Zahar Ed., 1994. p. 127-193.

FAIRCLOUGH, N. Discurso e mudança social. Brasília: Editora Universidade de Brasília, 2001 (2008, reimpressão).

FOLHA DE S.PAULO. Entenda como é feita a pesquisa Folha Top of Mind e os critérios adotados. Folha de S.Paulo, 2015. Disponível em: $<$ http://www1.folha.uol.com.br/topofmind/2015/10/1697355-entenda-como-e-feita-apesquisa-folha-top-of-mind-e-os-criterios-adotados.shtml>. Acesso em: 26out.2015.

FOUCART, C. Thomas Mann: idealização da vida burguesa. In: MONTANDON, A. (org.) 0 livro da hospitalidade: acolhida do estrangeiro na história e nas culturas. São Paulo: Senac, 2011. Cap. Quarta Parte, p. 957-967.

FOUCAULT, M. As palavras e as coisas. São Paulo: Martins Fontes, 2007.

A ordem do discurso: Aula inaugural no Collège de France, pronunciada em 2 de dezembro de 1970. 23 ${ }^{\text {a }}$ ed. São Paulo: Edições Loyola, 2013. 
FURLANETO, A. Exposição de R\$ 9 milhões traz ao Rio, em maio, obras de Dalí. O Globo, 2014. Disponível em: <http://oglobo.globo.com/cultura/exposicao-de-9-milhoes-traz-ao-rioem-maio-obras-de-dali-11936839>. Acesso em: 13out.2014.

G1 DF. CCBB de Brasília é o 38 museu mais visitado do mundo em 2014: A exposição 'Obsessão infinita' de Yayoi Kusama foi a $11^{\text {a }}$ mais popular. G1, 2015. Disponível em: <http://g1.globo.com/distrito-federal/noticia/2015/04/ccbb-de-brasilia-e-o-38-museu-maisvisitado-do-mundo-em-2014.html> . Acesso em: 12abril/2015.

GASTAL, S.; MOESCH, M. M. Turismo, Políticas Públicas e Cidadania. São Paulo: Aleph, 2007.

GEERTZ, C. A interpretação das culturas. Rio de Janeiro: LTC S.A., 1989.

GIDDENS, A. Modernidade e Identidade. Rio de Janeiro: Jorge Zahar, 2002.

GOTMAN, A. França contemporânea: uma bricolagem pós-moderna. In: MONTANDON, A. (org.). O livro da hospitalidade: acolhida do estrangeiro na história e nas culturas. São Paulo: Senac, 2011. p. 97-104.

GOTMAN, A. Marcel Mauss: uma estação sagrada da vida social. In: MONTANDON, A. (org.). O livro da hospitalidade: acolhida do estrangeiro na história e nas culturas. São Paulo: Senac, 2011a. p. 73-81.

GOVERNO DO DISTRITO FEDERAL. Revista Projeto Orla, Brasília XXI. Brasília: GDF, 1995.

GOVERNO FEDERAL. CCBB, um anfitrião cultural. Blog do Planalto, 2009. Disponível em: <http://blog.planalto.gov.br/ccbb-um-anfitriao-cultural/>. Acesso em: 19out.2015.

GRABURN, N. Antropologia ou antropologias do turismo? In: GRABURN, N., et al. Turismo e Antropologia: Novas abordagens. Campinas, SP: Papirus, 2009. p. 13-52.

GRASSI, M.-C. Hospitalidade: Transpor a soleira. In: MONTANDON, A. (org.). O livro da hospitalidade: acolhida do estrangeiro na históra e nas culturas. São Paulo: Senac, 2011. p. 45-53.

HALL, S. A identidade cultural na pós-modernidade. Rio de Janeiro: DP\&A, 2004.

HALLIDAY, M. A. K. On language and linguistics. London: Continuum, v. 3, 2003.

HENRIQUE, K. Por dentro do Centro. Correio Braziliense, Brasília (DF), 12out.2000, p.1.

HONNETH, A. Teoria Crítica. In: GIDDENS, A.; TURNER, J. (orgs.). Teoria social hoje. São Paulo: UNESP, 1999. p. 503-552.

HORKHEIMER, M.; ADORNO, T. W. A indústria cultural: O Iluminismo como mistificação de massa. In: LIMA, L. C. (org.). Teoria da cultura de massa. $6^{\text {a }}$ ed. São Paulo: Paz e Terra, 2011. p. 179-238.

IBGE. PNAD 2013 - Acesso à Internet e à Televisão e Posse de Telefone Móvel Celular para Uso Pessoal. Instituto Brasileiro de Geografia e Estatística, 2014. Disponível em: $<$ http://www.ibge.gov.br/estadosat/temas.php?sigla=df\&tema=pnad_internet_celular_2013>. Acesso em: 20 jan. 2016.

JAFARI, J. La cientifización del turismo. Estudios y Perspectivas en Turismo, Buenos Aires, v. 3, n. CIET - Centro de Investigaciones y Estudios Turísticos, p. 7-36, janeiro 1994. ISSN 1 - http://www.franciscohuertas.com.ar/wp-content/uploads/2011/04/IT_Jafari.pdf. 
KRIPPENDORF, J. Sociologia do Turismo: Para uma nova compreensão do lazer e das viagens. 3ª ed. São Paulo: Aleph, 2003.

LARAIA, R. D. B. Cultura: Um conceito antropológico. Rio de Janeiro: Jorge Zahar Ed., $1986\left(26^{\text {a }}\right.$, reimpressão, 2014).

LÉVY, P. As tecnologias da inteligência: $O$ futuro do pensamento na era da informática. $1^{\text {a }}$. ed. Rio de Janeiro: Editora 34, 1993.

O que é o virtual? Tradução de Paulo Neves. São Paulo: Ed.34, 1996.

LIMA, I. R.; ALLAN, R. Paula Sayão fala em entrevista sobre sua administração do CCBB.

Correio Braziliense, Brasília, 10jun.2012. Disponível em:

http://www.correiobraziliense.com.br/app/noticia/diversao-e-

arte/2012/06/10/interna_diversao_arte,306465/paula-sayao-fala-em-entrevista-sobre-suaadministracao-do-ccbb.shtml. Acesso em: 13out.2014.

LUNA, S. V. D. Planejamento de Pesquisa: Uma introdução. São Paulo: EDUC, 2002.

MACIEL, N. Endereço das artes. Correio Braziliense, Brasília (DF), 11 out. 2000, p.20.

MAINGUENEAU, D. A Análise do discurso e suas fronteiras. Matraga, Rio de Janeiro, v. 14, p. 13-37, jan/jun 2007. ISSN 20.

Gênese dos discursos. Tradução de Sírio Possenti. São Paulo: Parábola

Editorial, 2008 (2012, reimpressão).

MARTINO, L. C. A atualidade mediática: O conceito e suas dimensões. Compós Associação Nacional dos Programas de Pós-Graduação em Comunicação. ISSN Versão revisada (nov./2012) do trabalho apresentado no Grupo de Trabalho "Epistemologia da Comunicação", do XVIII Encontro da Compós, na PUC-MG, Belo Horizonte-MG, em jun./2009. Disponível em: <www.compos.org.br>. Acesso em: 18abr.2015.

MEIO E MENSAGEM. Facebook tem 89 milhões de usuários no Brasil. Meio e Mensagem, 2014. Disponível em:

<http://www.meioemensagem.com.br/home/midia/noticias/2014/08/22/Facebook-tem-89milhoes-de-usuarios-no-Brasil.html>. Acesso em: 21nov.2015.

MESQUITA, J. C. F. Prefácio: Cidadania já! In: MATTA, R. E. O. Brasileiro: cidadão? 1ª ed. São Paulo: Cultura Editores Associados, 1992. p. XI-XIII.

MICHAUD, G. Jacques Derrida: um pensamento do incondicional. In: MONTANDON, A. (org.). O livro da hospitalidade: acolhida do estrangeiro na história e nas culturas. São Paulo: Senac, 2011. p. 1001-1011.

MINISTÉRIO DA CULTURA. Salicnet. Ministério da Cultura, s/d. Disponível em: <http://sistemas.cultura.gov.br/salicnet/Salicnet/Salicnet.php>. Acesso em: 03out.2015.

MOESCH, M. M. Para além das disciplinas: O desafio do próximo século. In: GASTAL, S. (org.). Turismo: Investigação e crítica. São Paulo: Contexto, 2002, p. 25-44.

Epistemologia Social do Turismo. Universidade de São Paulo. São Paulo, 2004. Tese apresentada à Escola de Comunicação e Arte da Universidade de São Paulo.

MOLINA, S. O pós-turismo. $2^{\text {a }}$ ed. São Paulo: Aleph, 2003.

MONTANDON, A. Introdução: Definições. In: (org.). O livro da hospitalidade: acolhida do estrangeiro na história e nas culturas. São Paulo: Senac, 2011c. p. 41-43. 
Introdução: Filosofia, Política e Sociedade. In:

(org.).

O livro da hospitalidade: acolhida do estrangeiro na história e nas culturas. São Paulo:

Senac, 2011b. p. 995-998.

Introdução: Mitos, Figuras e Representações. In:

(org.). O livro da hospitalidade: acolhida do estrangeiro na história e nas culturas. São Paulo: Senac, 2011. p. 713-716.

Prefácio: Espelhos da hospitalidade. In: (org.). $\mathbf{O}$

livro da hospitalidade: acolhida do estrangeiro na história e nas culturas. São Paulo: Senac, 2011a. p. 31-37.

MONTEIRO, I. P.; SOUSA, F. C. D. Innovation in Hospitality: the manager's role. In: Tourism development and management: challenges and opportunities for Algarve, Portugal. Algarve: Universidade do Algarve, 2010. p. 183-203.

MORIN, E. A integração cultural. In: Cultura de massas no século XX: Neurose. $9^{a}$. ed. Rio de Janeiro: Forense Universitária, v.1 (O espírito do tempo), 1997 (2002, reimpressão). p. 12-47.

MORIN, E. Introdução ao pensamento complexo. Tradução de Eliane Lisboa. $4^{a}$ ed. Porto Alegre: Sulina, 2011.

MURTA, S. M.; ALBANO, C. (orgs.). Interpretar o patrimônio: um exercício do olhar. Belo Horizonte: Editora UFMG; Território Brasilis, 2002.

NACIONES UNIDAS, ORGANIZACIÓN MUNDIAL DEL TURISMO. Entender el turismo: Glosario Básico, s/d. Disponível em: <http://media.unwto.org/es/content/entender-elturismo-glosario-basico>. Acesso em: 16abr2015. Acessado em 16abr.15.

Recomendaciones

sobre estadísticas de turismo. Departamento de Información Económica y Social y Análisis de Políticas, División de Estadística, 2000. ISSN Nueva York: Series M No 83 (Rev-1.0).

Disponível em: <http://unstats.un.org/unsd/statcom/doc00/m83-s.pdf〉. Acesso em: 25out.2014.

NEVES, R. M. Consumo do tempo livre: perspectiva interdisciplinar da comunicação e da hospitalidade virtual. Anais do XXXII Congresso Brasileiro de estudos interdisciplinares de comunicação (INTERCOM), Curitiba/PR, 04 a 07set.2009. p. 1-12.

NEVES, R. M.; ALEXANDRE, L. Consumo da hospitalidade na hiper realidade pósmoderna. III CONVIBRA - Congresso Virtual Brasileiro - Administração, São Paulo, 24 a 26 nov.2006. p. 1-10.

OLIVEIRA, J. L. Texto Acadêmico: Técnicas de redação e de pesquisa científica. $8^{\mathrm{a}}$ ed. Petrópolis: Editora Vozes, 2012.

OLIVEIRA, L. L. Cultura é patrimônio: Um guia. Rio de Janeiro: FGV, 2008 (reimpressão, 2009).

OLIVEIRA, M. M. D. Como fazer pesquisa qualitativa. Petrópolis: Editora Vozes, 2007.

ORLANDI, E. P. Análise de discurso: Princípios \& procedimentos. $11^{\text {a }}$ ed. Campinas, SP: Pontes Editores, 2013.

ORTIZ, R. A Escola de Frankfurt e a Questão da Cultura. Associação Nacional de PósGraduação e Pesquisa em Ciências Sociais (Anpocs), 1986. Disponível em: <http://www.anpocs.org.br/portal/publicacoes/rbcs_00_01/rbcs01_05.htm>. Acesso em: 11jun.2015. 
PASCHOALI, A.; APEN, A. 2012. Brasília, 2012. Disponível em: https://www.youtube.com/watch?v=i-ScDlaOD4c. Acesso em: 29set.2015.

PESAVENTO, S. J. História \& História cultural. $2^{\mathrm{a}}$ ed. (2 $2^{\mathrm{a}}$ reimpressão). Belo Horizonte: Autêntica, 2008.

PILAGALLO, O. Caixa e Banco do Brasil são os mais citados quando o assunto é dinheiro. Folha de São Paulo, 2015. Disponível em:

<http://www1.folha.uol.com.br/topofmind/2015/10/1696718-caixa-e-banco-do-brasil-sao-osmais-citados-quando-o-assunto-e-dinheiro.shtml>. Acesso em: 26out.2015.

PINSKY, J.; PINSKY, C. B. (orgs.). História da cidadania. $4^{a}$ ed. São Paulo: Contexto, 2008.

PRINCE, N. Fantástico: a hostilidade posta em arte. In: MONTANDON, A. (org.). O livro da hospitalidade: acolhida do estrangeiro na história e nas culturas. São Paulo: Senac, 2011. p. 855-861.

PROPMARK. AgênciaClick Isobar conquista conta do Banco do Brasil. Propmark, 2012. Disponível em: <http://propmark.com.br/agencias/agenciaclick-isobar-e-a-nova-agencia-dobanco-do-brasil>. Acesso em: 12dez.2015.

RIBEIRO, L. F. O conceito de linguagem em Bakhtin. Revista Brasil, 2006. Disponível em: <http://revistabrasil.org/revista/artigos/crise.htm\#10>. Acesso em: 20nov.2015.

RIBEIRO, O. J. Educação e novas tecnologias: um olhar para além da técnica. In:

COSCARELLI, C. V.; RIBEIRO, A. E. (orgs.). Letramento Digital: Aspectos sociais e possibilidades pedagógicas. 2a . ed. Belo Horizonte: Ceale; Autêntica, 2007. p. 85-97.

ROSA, M. D. G. D. A história da educação através dos textos. 19ª ed. São Paulo: Cultrix, 1993.

ROSENDAHL, Z. Cultura, turismo e identidade. In: NUSSBAUMER, G. M. (org.). Teorias \& políticas da cultura: visões multidisciplinares. Salvador: EDUFBA, 2007. p. 245-256. Disponível em:

https://repositorio.ufba.br/ri/bitstream/ufba/139/1/Teorias\%20e\%20politicas\%20da\%20cultur a.pdf. Acesso em: out.2014.

SANTOS, B. S. Um discurso sobre as ciências. 2a . ed. São Paulo: Cortez, 2004.

. Para um novo senso comum: A ciência, o direito e a política na transição paradigmática. Crítica da razão indolente: Contra o desperdício da experiência. vol.1. $8^{\mathrm{a}}$. ed. (1 ${ }^{\mathrm{a}}$ reimpressão). São Paulo: Cortez, 2011.

SANTOS, E. M. D. Chat: E agor@? Novas regras - nova escrita. In: COSCARELLI, C. V.; RIBEIRO, ANA ELISA (orgs.). Letramento Digital: Aspectos sociais e possibilidades pedagógicas. 2a . ed., Belo Horizonte: Ceale; Autêntica, 2007. p. 151-183.

SANTOS, L. G. A desordem da nova ordem: Aceleração tecnológica e ruptura do referencial. In: VIANA, G.; SILVA, M.; DINIZ, N. (orgs.). O desafio da sustentabilidade: Um debate socioambiental no Brasil. São Paulo: Editora Fundação Perseu Abramo, 2001, p.27-41.

SANTOS, M. A Natureza do Espaço: Técnica e tempo, razão e emoção. $4^{\mathrm{a}}$ ed. ( $2^{\mathrm{a}}$ reimpressão), São Paulo: Editora da Universidade de São Paulo, 2006.

Metamorfoses do espaço habitado: fundamentos teórico e metodológico da Geografia. 6a. ed. São Paulo: Hucitec, 2008. 
SCHIFFRIN, D. Definitions of Discourse. In: Oxford: Blackwell Publishers, 1994 (1997, reimpressão). p. 20-43.

Approaches to Discourse.

SCHWAB, G. As mais belas histórias da antiguidade clássica: os mitos da Grécia e de Roma. Rio de Janeiro: Paz e Terra, 1994.

SCHWANDT, T. A. Três posturas epistemológicas para a investigação qualitativa: Interpretativismo, hermenêutica e construcionismo social. In: DENZIN, N.; LINCOLN, Y. (orgs.) $\mathrm{O}$ planejamento da pesquisa qualitativa: Teorias e abordagens. $2^{\mathrm{a}}$ ed. Porto Alegre: Artmed, 2006 (2008, reimpressão). p. 193-217.

SERPA, A. Espaço público e acessibilidade: Notas para uma abordagem geográfica.

GEOUSP: Espaço e Tempo, São Paulo, no 15, p. 21-37, 2004. Disponível em: http://www.geografia.fflch.usp.br. Acesso em: 29abr.2015.

Contexto, 2014.

O espaço público na cidade contemporânea. $2^{\mathrm{a}}$ ed. ( $1^{\mathrm{a}}$ reimpressão), São Paulo:

SERRATE, G. Em 2012 vou viver no CCBB. Youtube, 2012. Disponível em:

<https://www.youtube.com/watch?v=cHS4145LakE>. Acesso em: 29set.2015.

SILVA, D. E. G. D. Metáforas sob a lupa da Análise de Discurso Crítica. In:

(org.). Língua, Gramática e Discurso. Goiânia: Cânone Editorial, 2006. p. 161-178.

Estudos críticos do discurso no contex to brasileiro (por uma rede de

transdisciplinaridade). Eutomia - Revista de Literatura e Linguística, Recife: UFPE, n. 9a p. 224-243, jul./2012. ISSN Ano V.

A gramática da pobreza em práticas discursivas de atores sociais: Uma

perspectiva crítica. In: PINTO, J. P.; FABRÍCIO, B. F. (orgs.). Exclusão social e

microrresistências: A centralidade das práticas discursivo-identitárias. Goiânia: Cânone Editorial, 2013. p. 88-111.

SILVERMAN, D. Interpretação de dados qualitativos: Métodos para análise de entrevistas, textos e interações. Porto Alegre: Artmed, 2009.

SIQUEIRA, D. História social do turismo. Rio de Janeiro: Garamond; Brasília: Ed. Vieira, 2005.

SMOLIAROVA, T. Arquitetura: artefato de boas-vindas. In: MONTANDON, A. (org.). O livro da hospitalidade: acolhida do estrangeiro na história e nas culturas. São Paulo: Senac, 2011. p. 439-451.

SOUZA, E. F. D. A moeda da arte: a dinâmica dos campos artísticos e econômico no patrocínio do CCBB. São Paulo: Ateliê Editorial, 2013.

Assim. bem CCBB. Revista do Correio, Brasília, junho 2011. ISSN

http://www.correiobraziliense.com.br/app/noticia/revista/2011/06/24/interna_revista_correio, 258370/assim-bem-ccbb.shtml.

THE ART NEWSPAPER. Visitor Figures: Exhibition \& museum attendance figures 2011.

The Art Newspaper, 2012. ISSN 234. Disponível em: <http://www.museus.gov.br/wpcontent/uploads/2012/03/ArtNewspaper_Ranking2011.pdf>. Acesso em: 15abr.2015.

THE ART NEWSPAPER. Special Report: Visitor Figures 2012. The Art Newspaper, p. 1529, abril 2013. ISSN Seção 2, n245. Disponível em: <http://theartnewspaper.com/>. 
THE ART NEWSPAPER. Visitor Figures 2012: Exhibition e museum attendance survey. The Art Newspaper - Special Report, Londres, p. 15-29, abril/2013. ISSN 245. Disponível em: 〈http://theartnewspaper.com/news/museums/>. Acesso em: 21 abr.2015.

THE ART NEWSPAPER. Visitor Figures 2013: Museum and exhibition attendance numbers compiled and analysed. The Art Newspaper - Special Report, abr/2014. ISSN 256. Disponível em: <http://www.museus.gov.br/wpcontent/uploads/2014/04/TheArtNewspaper2013_ranking.pdf $>$. Acesso em: 21abr.2015.

THE ART NEWSPAPER. Visitor Figures 2014: The grand totals: exhibition and museum attendance numbers worldwide. The Art Newspaper - Special Report, London, p. 15, abril/2015. ISSN 267. Disponível em: <http://www.museus.gov.br/wpcontent/uploads/2015/04/TheArtNewspaper_Ranking2014.pdf>. Acesso em: 21abr.2015.

TURLÃO, F. Doze agências na “quente” licitação do BB. Meio \& Mensagem, 2012. Disponível em:

<http://www.meioemensagem.com.br/home/comunicacao/noticias/2012/06/14/Dozeagencias-na-quente-licitacao-do-BB.html>. Acesso em: 12dez.2015.

URRY, J. O olhar do turista: Lazer e viagens nas sociedades contemporâneas. São Paulo: Editora Studio Nobel: Sesc, 1996 (reimpressão, 2001).

VIEIRA, M. E. D. M. Distinção, cultura de consumo e gentrificação: O Centro Cultural Banco do Brasil e o mercado de bens simbólicos, Brasília, fevereiro 2006. Tese apresentada ao Departamento de Sociologia da Universidade de Brasília/UnB.

WILLIAMS, R. Cultura. 2011 (reimpressão). São Paulo: Paz e Terra, 1992.

XAVIER, A. C.; SANTOS, C. F. XAVIER, Antônio Carlos. SANTOS, Carmi Ferraz. Eforum na Internet: um Gênero Digital. In: ARAÚJO, J. C.; BIASI-RODRIGUES, B.

Interação na Internet - Novas Formas de Usar a Linguagem. Rio de Janeiro: Lucerna, 2005. p. 30-38.

YÁZIGI, E. A alma do lugar: turismo, planejamento e cotidiano. São Paulo: Contexto, 2001.

YÁZIGI, E.; CARLOS, A. F. A.; CRUZ, R. D. C. A. D. (orgs.). Turismo: espaço, paisagem e cultura. $1^{\text {a }}$. ed. São Paulo: Hucitec, 1996.

YÚDICE, G. A conveniência da cultura. In: A conveniência da cultura: Usos da cultura na era global. Belo Horizonte: Editora UFMG, 2004. p. 25-64.

ZAGHEN, P. E. M. Banco do Brasil, empresa cidadã. Correio Braziliense, Brasília (DF), p.5, 05out.2000. 


\section{ANEXOS}

Imagem 3 - Maquete do projeto original de Oscar Niemeyer para o Centro de Formação do Banco do Brasil, disponível na entrada administrativa do CCBB DF

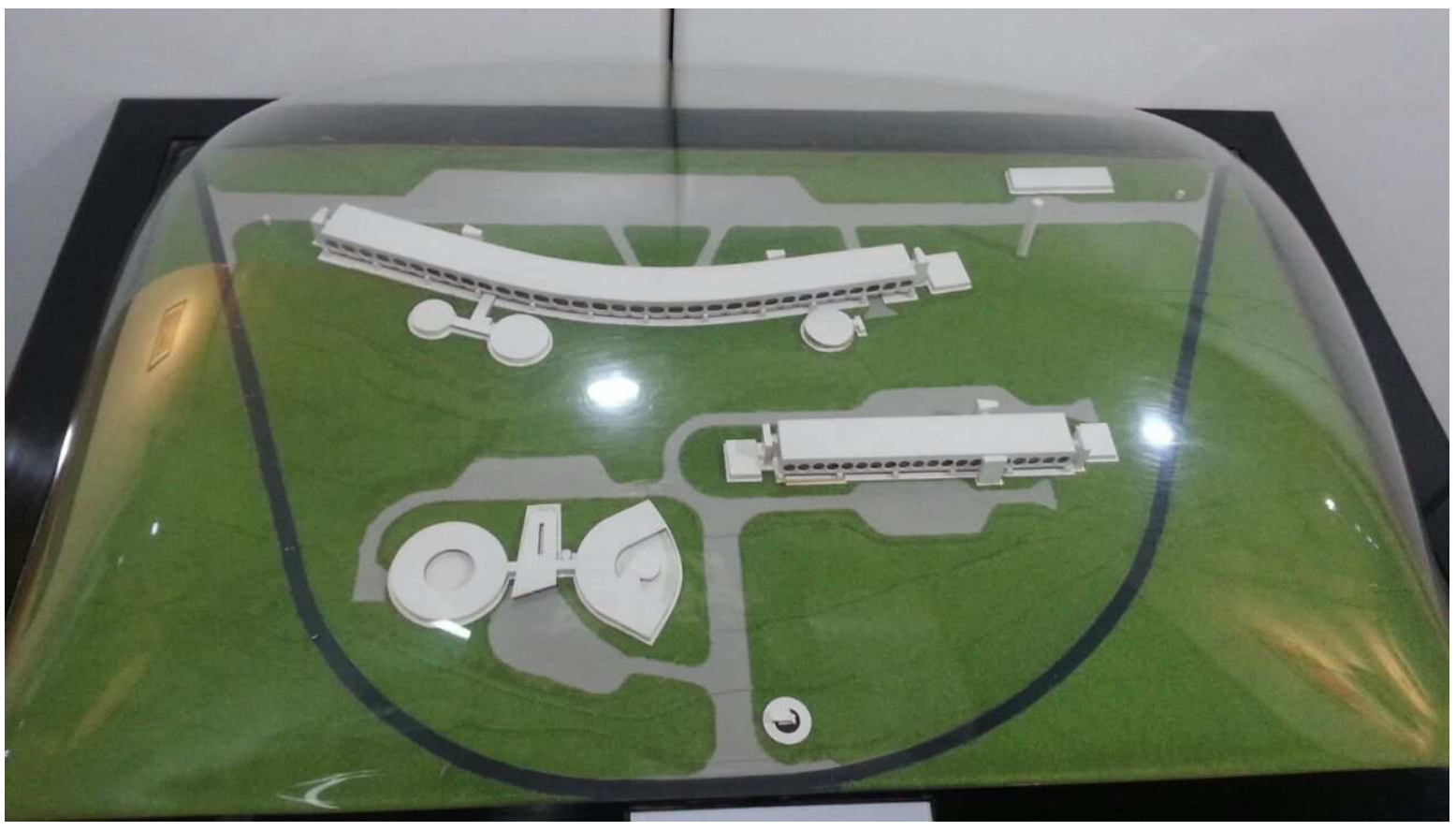

Fonte: Foto tirada pela própria pesquisadora - Brasília (DF), 280ut 2014

Imagem 4 - Vista panorâmica do CCBB DF, com Casulo, de Darlan Rosa - mostra permanente, tendo ao fundo, à direita, um dos pavilhões de vidro (não previsto no projeto de Niemeyer, sendo construído em 2012 para abrigar a mostra "Corpos Presentes - Still Being”, de Antony Gormley)

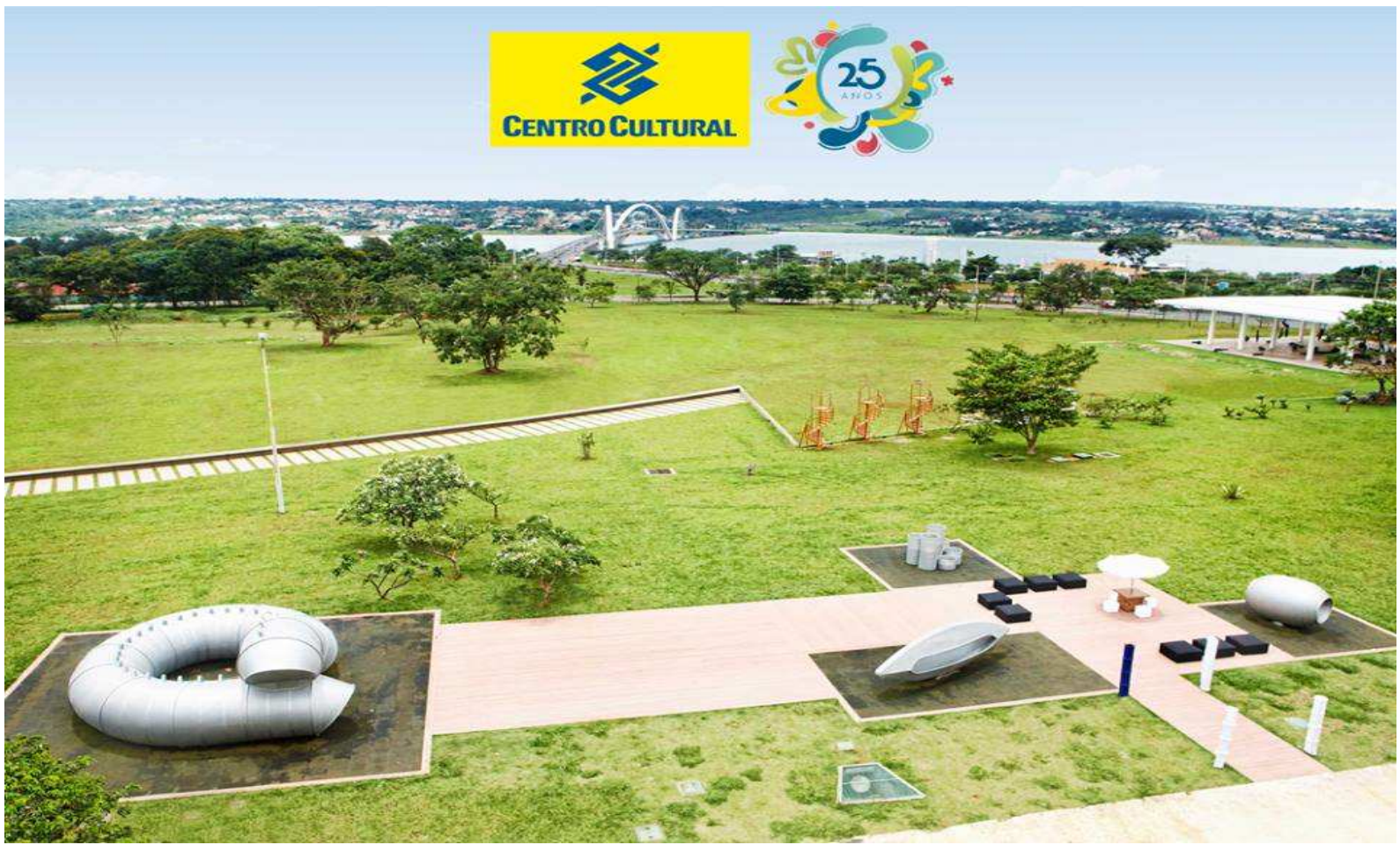

Fonte:

https://www.facebook.com/ccbb.brasilia/photos/pb.225664190779258.2207520000.1414803913./838234139522257/?type=3\&theater 
Imagem 5 - Améfrica, de Denise Milan - mostra permanente do CCBB DF

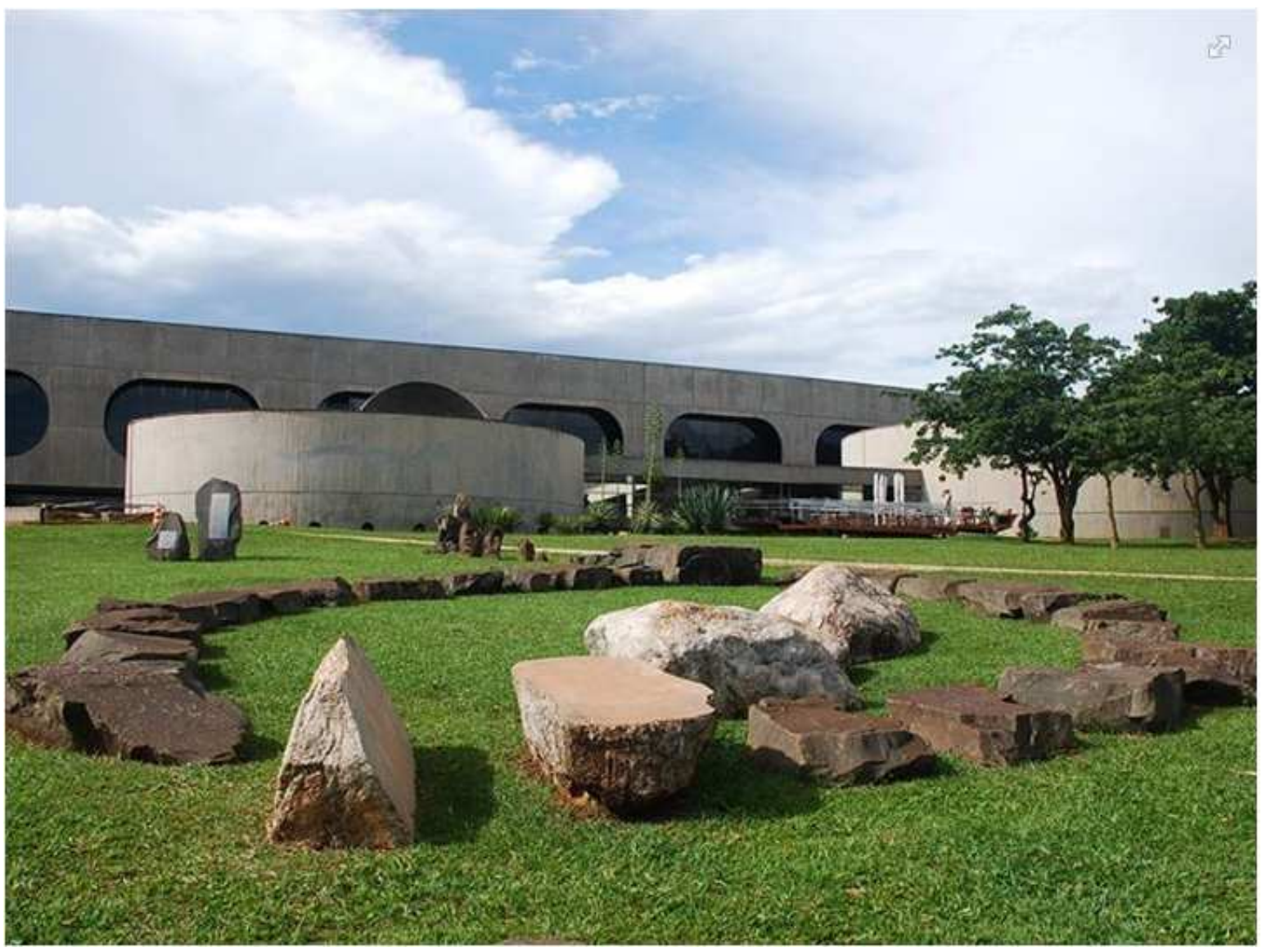

Fonte:

https://www.facebook.com/ccbb.brasilia/photos/a.229081323770878.67803.225664190779258/929703863708617/?type=1\&theater

Imagem 6 - Antiga Biblioteca da Gerência de Pessoas, desde 2014 espaço expositivo do CCBB DF

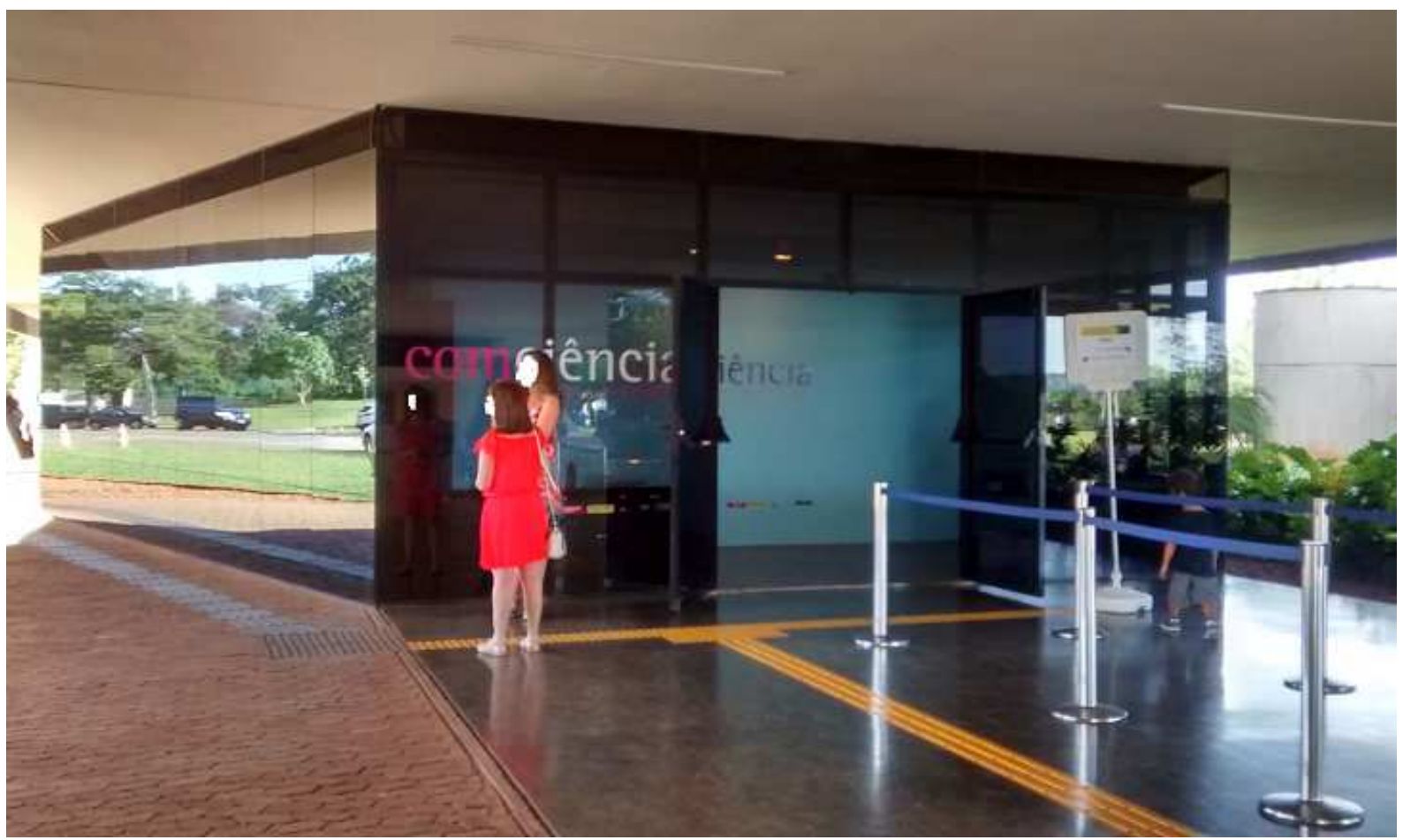

Fonte: Foto tirada pela própria pesquisadora - Brasília (DF), 30 de janeiro de 2016 
Imagem 7 - Vista do Pavilhão de vidro, um dos espaços não previstos na obra original de Niemeyer e que desde 2008 integra a área construída do CCBB DF.

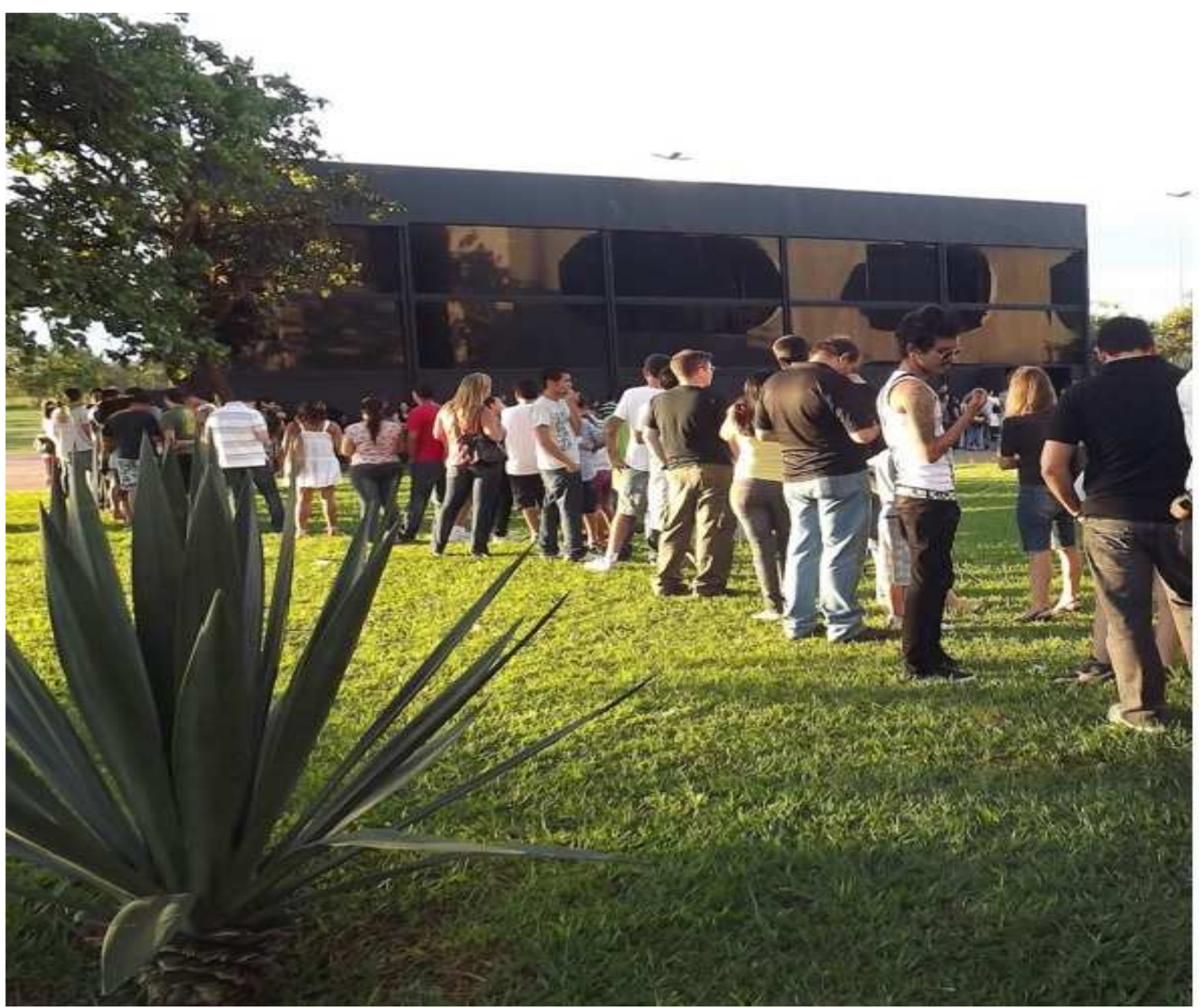

Fonte: http://2.bp.blogspot.com/-BnmgWWMCbTw/T0pBmqQBtrI/AAAAAAAABIY/FpuKHhcAzUI/s1600/DSCF3416+$+\mathrm{C} \% 25 \mathrm{C3} \% 25 \mathrm{~B} 3 \mathrm{pia} . \mathrm{JPG}$

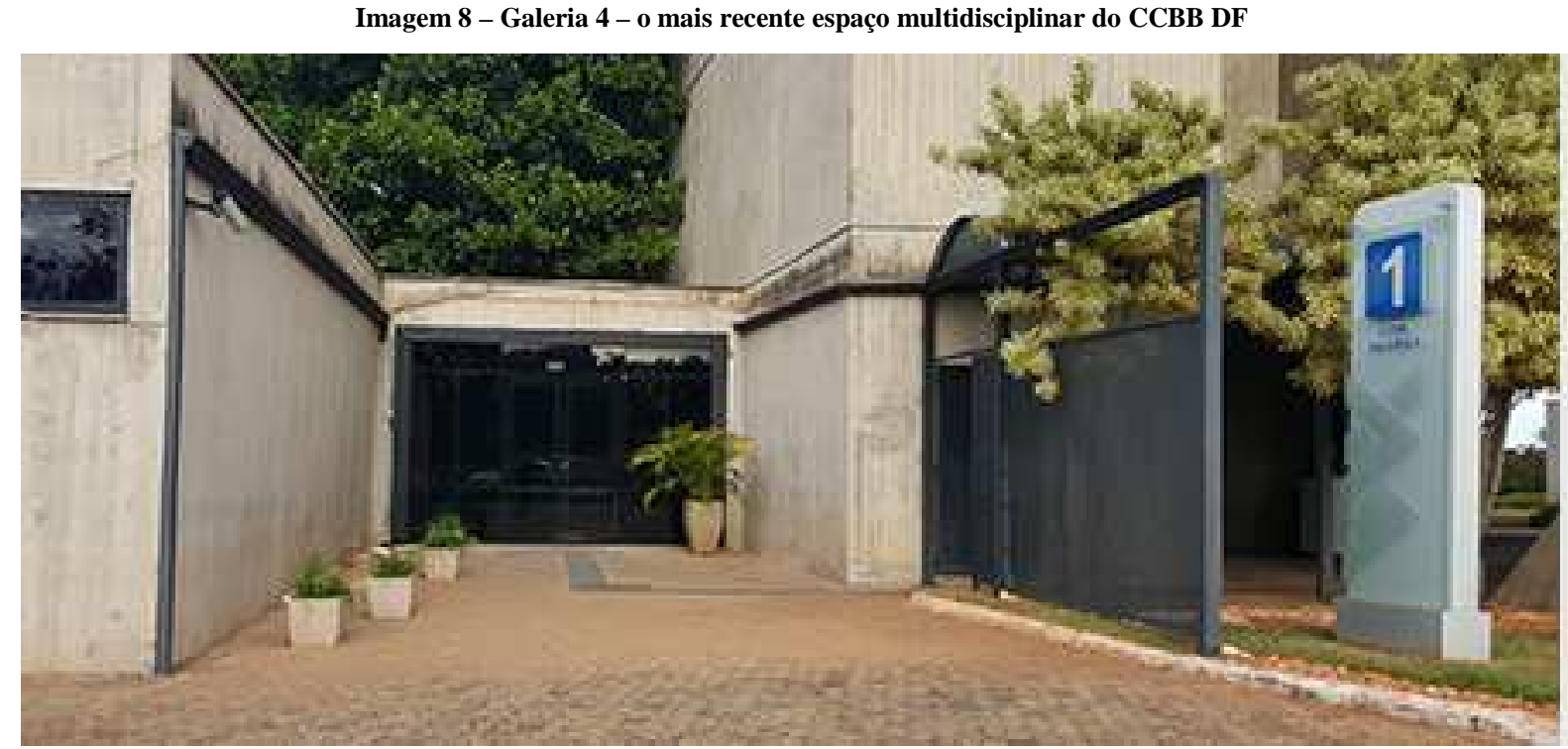

Fonte: http://culturabancodobrasil.com.br/portal/distrito-federal/galeria/ 
Imagem 9 - Livraria e bistrô

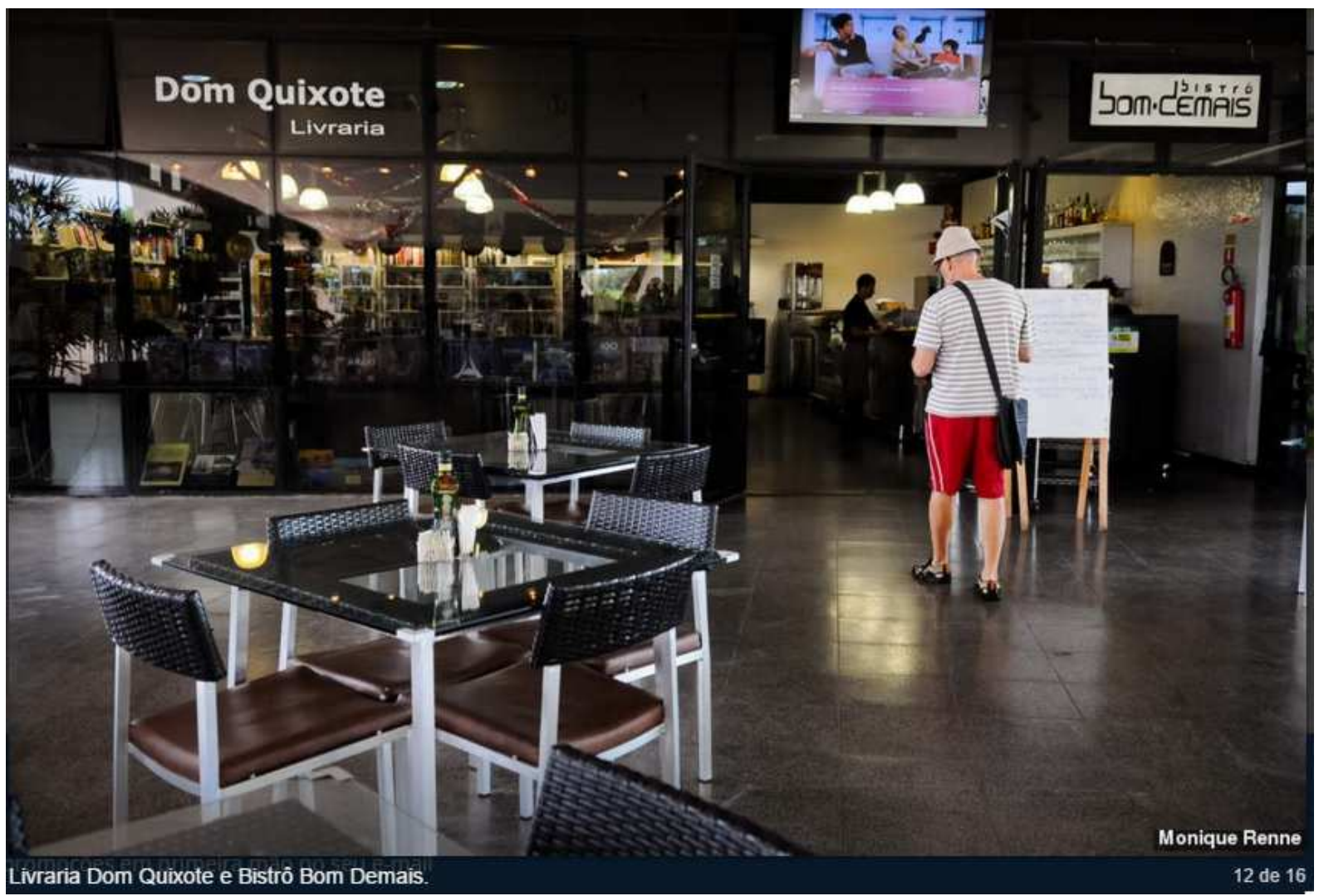

Fonte: http://guia.melhoresdestinos.com.br/brasilia-vidacultural-ccbb-57-1572-l.html

Imagem 10 - Cartão fidelidade do cinema do CCBB DF
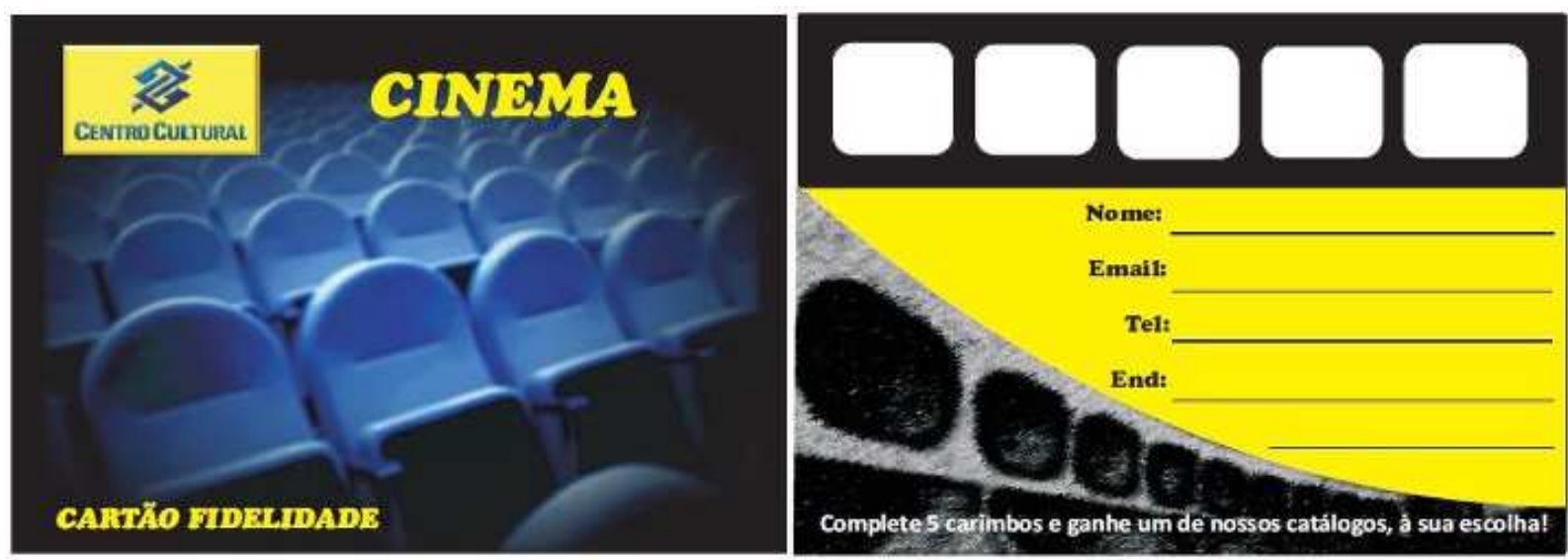

Fonte:

https://www.facebook.com/ccbb.brasilia/photos/a.229081323770878.67803.225664190779258/255254907820186/?type=3\&theater 
Imagem 11 - Ônibus gratuito - adesivos que remetem à exposição de Yayoi Kusama

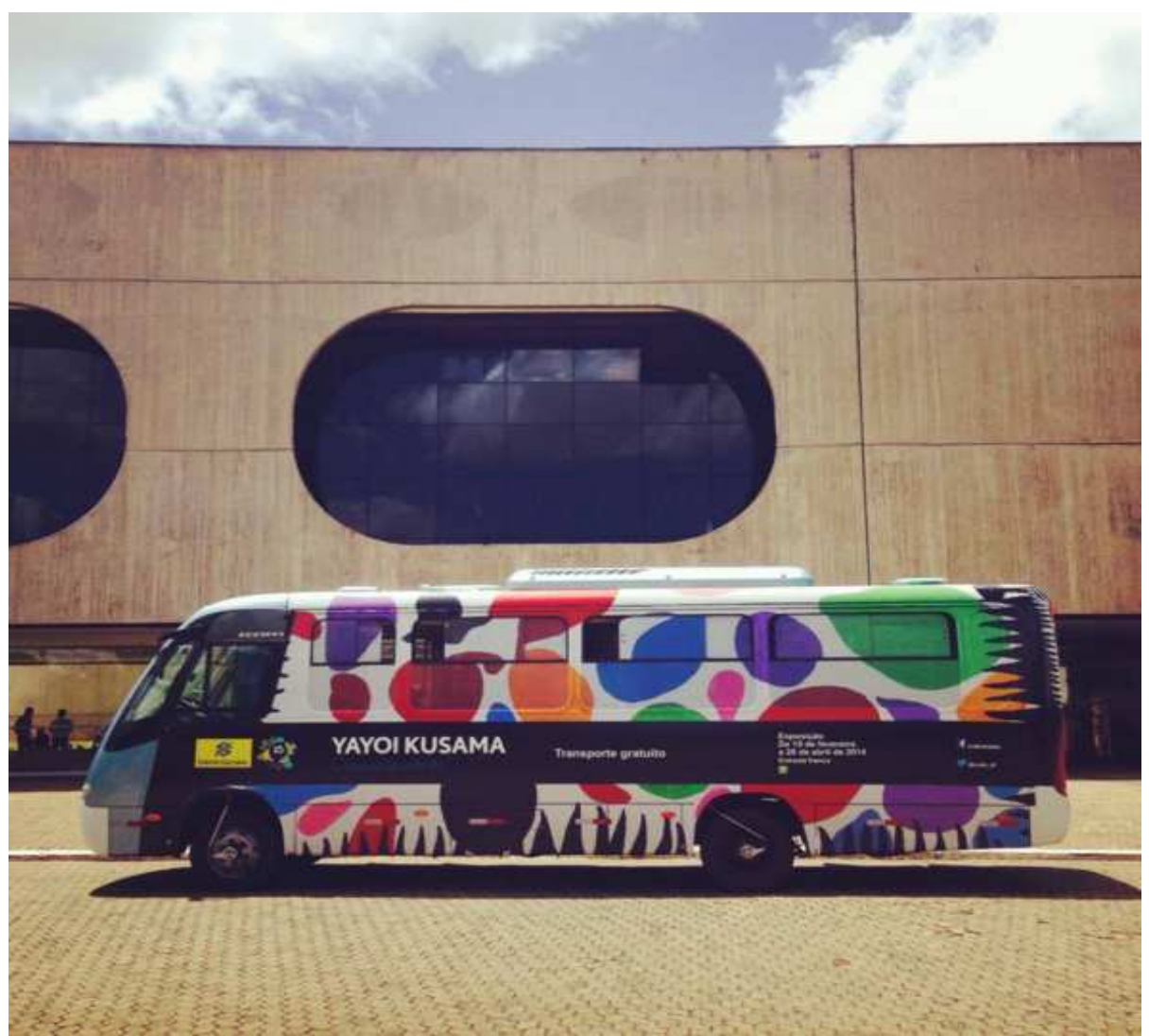

Fonte: https://www.facebook.com/ccbb.brasilia/photos/a.654242834588056.1073741850.225664190779258/742280359117636/?type=3\&theater

Imagem 12 - Edifício Tancredo Neves - estrutura abriga o administrativo do CCBB DF, além de cinema, galeria, bilheteria e as instalações do futuro Museu do Banco do Brasil

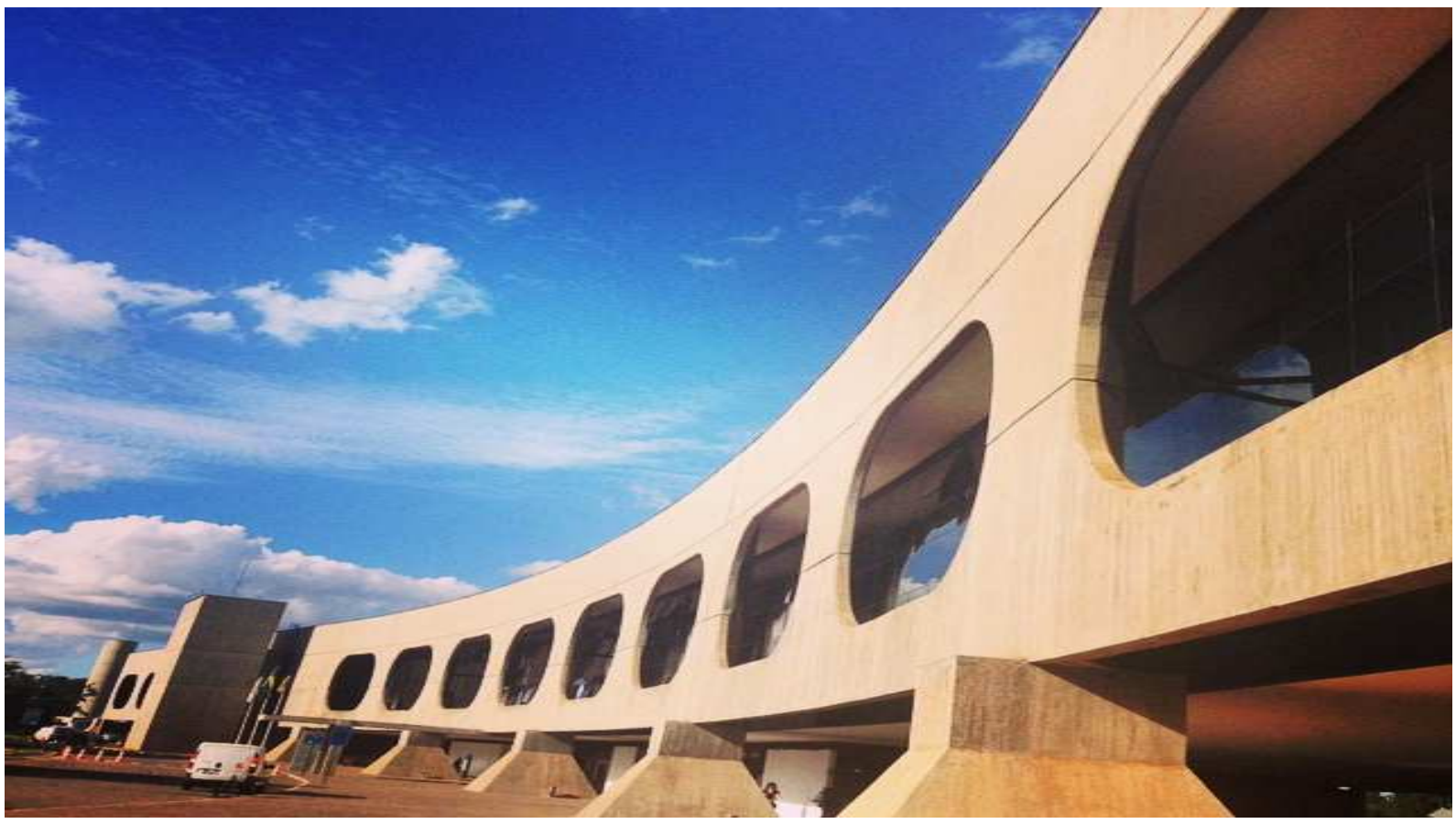

Fonte:

https://www.facebook.com/ccbb.brasilia/photos/pb.225664190779258.2207520000.1414803797./885437848135219/?type=3\&theater 